VILNIAUS GEDIMINO TECHNIKOS UNIVERSITETAS

Dovydas RIMDŽIUS

\title{
VĖJO ENERGIJĄ NAUDOJANČIO TURBININIO VENTILIATORIAUS TERMODINAMINIS MODELIS
}

DAKTARO DISERTACIJA

TECHNOLOGIJOS MOKSLAI,

MECHANIKOS INŽINERIJA (T 009)

Vilnius, 2021 
Disertacija rengta 2016-2021 metais Vilniaus Gedimino technikos universitete.

Vadovas

prof. habil. dr. Vytautas MARTINAITIS (Vilniaus Gedimino technikos universitetas, mechanikos inžinerija - T 009).

Vilniaus Gedimino technikos universiteto Mechanikos inžinerijos mokslo krypties disertacijos gynimo taryba:

\section{Pirmininkas}

doc. dr. Artūras KILIKEVIČIUS (Vilniaus Gedimino technikos universitetas, mechanikos inžinerija - T 009).

\section{Nariai:}

prof. habil. dr. Rimantas KAČIANAUSKAS (Vilniaus Gedimino technikos universitetas, mechanikos inžinerija - T 009),

dr. Fernando MARQUES DA SILVA (Nacionalinė civilinès inžinerijos laboratorija, Portugalija, mechanikos inžinerija - T 009),

dr. Raimondas PABARČIUS (Lietuvos energetikos institutas, energetika ir termoinžinerija - T 006),

doc. dr. Kęstutis VALANČIUS (Vilniaus Gedimino technikos universitetas, mechanikos inžinerija - T 009).

Disertacija bus ginama viešame Mechanikos inžinerijos mokslo krypties disertacijos gynimo tarybos posėdyje $2021 \mathrm{~m}$. balandžio 27 d. 10 val. Vilniaus Gedimino technikos universiteto senato posèdžių salèje.

Adresas: Sauletekio al. 11, LT-10223 Vilnius, Lietuva.

Tel.: (8 5) 274 4956; faksas (8 5) 270 0112; el. paštas doktor@vilniustech.lt

Pranešimai apie numatomą ginti disertaciją išsiųsti $2021 \mathrm{~m}$. kovo $26 \mathrm{~d}$.

Disertaciją galima peržiūrèti Vilniaus Gedimino technikos universiteto talpykloje http://dspace.vgtu.lt ir Vilniaus Gedimino technikos universiteto bibliotekoje (Saulètekio al. 14, LT-10223 Vilnius, Lietuva).

Vilniaus Gedimino technikos universiteto 2021-007-M mokslo literatūros knyga

doi:10.20334/2021-007-M

(C) Vilniaus Gedimino technikos universitetas, 2021

(C) Dovydas Rimdžius, 2021

dovydas.rimdzius@vilniustech.lt 
VILNIUS GEDIMINAS TECHNICAL UNIVERSITY

Dovydas RIMDŽIUS

THERMODYNAMIC MODEL OF WIND DRIVEN TURBINE VENTILATOR

DOCTORAL DISSERTATION

TECHNOLOGICAL SCIENCES,

MECHANICAL ENGINEERING (T 009)

Vilnius, 2021 
Doctoral dissertation was prepared at Vilnius Gediminas Technical University in 2016-2021.

\section{Supervisor}

Prof. Dr Habil. Vytautas MARTINAITIS (Vilnius Gediminas Technical University, Mechanical Engineering - T 009).

The Dissertation Defence Council of Scientific Field of Mechanical Engineering of Vilnius Gediminas Technical University:

\section{Chairman}

Assoc. Prof. Dr Artūras KILIKEVIČIUS (Vilnius Gediminas Technical University, Mechanical Engineering - T 009).

\section{Members:}

Prof. Dr Habil. Rimantas KAČIANAUSKAS (Vilnius Gediminas Technical University, Mechanical Engineering - T 009),

Dr Fernando MARQUES DA SILVA (National Laboratory for Civil Engineering, Portugal, Mechanical Engineering - T 009),

Dr Raimondas PABARČIUS (Lithuanian Energy Institute, Energetics and Power Engineering - T 006),

Assoc. Prof. Dr Kęstutis VALANČIUS (Vilnius Gediminas Technical University, Mechanical Engineering - T 009).

The dissertation will be defended at the public meeting of the Dissertation Defence Council of Mechanical Engineering in the Senate Hall of Vilnius Gediminas Technical University at 10 a. m. on 27 April 2021.

Address: Saulètekio al. 11, LT-10223 Vilnius, Lithuania.

Tel.: +370 5274 4956; fax +370 5270 0112; e-mail: doktor@ vilniustech.lt

A notification on the intend defending of the dissertation was send on 26 March 2021.

A copy of the doctoral dissertation is available for review at Vilnius Gediminas Technical University repository http://dspace.vgtu.lt and at the Library of Vilnius Gediminas Technical University (Saulètekio al. 14, LT-10223 Vilnius, Lithuania). 


\section{Reziumè}

Disertacijoje taikant eksperimentinius tyrimus ir sisteminès analizès metodus tiriami vejjo energiją naudojantys stoginiai turbininiai ventiliatoriai, jų veikimas, efektyvumas, funkcionalumas. Tiriamos galimybès padidinti vejjo energijos panaudojimo efektyvumą vėdinimui, esant stochastiniam vëjo kitimui metų cikle. Disertacijos tikslas - parengti eksperimentiškai nustatomomis mechaninèmis ir aerodinaminemis charakteristikomis paremtą turbininio ventiliatoriaus teorinị veikimo modelị.

Darbe sprendžiami šie pagrindiniai uždaviniai: pirmasis - parengti ir įvykdyti eksperimentinių tyrimų programą, kuria struktūrizuojami STV veikimo režimai ị atskirus srautinius procesus; antrasis - kiekybiškai ir kokybiškai palyginti skirtingu tokio tipo įrenginių eksperimentines charakteristikas; trečiasis pasiūlyti turbininio ventiliatoriaus konstrukciją ir tekèjimo procesus jame atspindinčią struktūrinio suskaidymo koncepciją; ketvirtasis - parengti turbininio ventiliatoriaus veikimo termodinamini modelị; penktasis - ịvertinti galimybes padidinti vejjo energijos panaudojimo efektyvumą turbininiuose ventiliatoriuose.

Disertaciją sudaro ivvadas, trys skyriai, bendrosios išvados, naudotos literatūros ir autoriaus publikacijų disertacijos tema sąrašai.

Ivadiniame skyriuje aptariama tiriamoji problema, darbo aktualumas, aprašomas tyrimų objektas, formuluojamas darbo tikslas bei uždaviniai, aprašoma tyrimų metodika, mokslinis darbo naujumas, ginamieji teiginiai, pristatomos disertacijos tema paskelbtos autoriaus publikacijos ir pranešimai konferencijose bei disertacijos struktūra.

Pirmajame skyriuje pateikiama vejjo energiją naudojančių natūralaus vėdinimo sistemų tyrimų apžvalga. Atliktos apžvalgos pagrindu suformuluoti tyrimo uždaviniai leidžiantys pasiekti tyrimo tikslą.

Antrajame skyriuje pristatoma turbininių ventiliatorių eksperimentinių tyrimų programa, metodika bei šių tyrimų rezultatai.

Trečiajame skyriuje pateiktas turbininio ventiliatoriaus veikimo termodinaminis modelis, kuris suformuotas eksperimentinių tyrimų pagrindu. Taip pat pateiktas teorinis turbininiu ventiliatorių funkcionalumo padidinimo vertinimas, kuomet įrenginys gali akumuliuoti perteklinę vẻjo energiją. 


\section{Abstract}

This dissertation studies, through application of experimental research and methods of systematic analysis, wind driven roof turbine ventilators, their mode of operation, effectiveness, and functionality. It furthermore looks into the possibilities to boost wind energy efficiency for ventilation purposes, based on stochastic variation of wind throughout the year-cycle. The aim of the dissertation is to prepare a theoretical model of turbine ventilator operation based on experimentally determined mechanical and aerodynamic characteristics.

The thesis addresses the following objectives: preparing and executing an experimental research programme to structure the operating modes of the RTV into separate flow processes; carrying out a quantitative and qualitative comparison of the experimental characteristics of different RTVs of this type; proposing a structural breakdown concept reflecting the turbine ventilator construction and flow processes inside it; designing a thermodynamic model of turbine ventilator operation; and evaluating the possibilities to improve the efficiency of the use of wind energy by turbine ventilators.

The dissertation consists of an introduction, three chapters, general conclusions, and lists of literature and scientific publications by the author on the topic of this dissertation.

The introduction covers the formulation of the problem, the relevance of the thesis, describes the object of research, formulates the aim and tasks of the thesis, describes the research methodology, the scientific novelty of the thesis, defended statements, outlines the author's publications and reports at science conferences on the topic of the dissertation, as well as the structure of the dissertation.

Chapter 1 presents a review of wind-driven natural ventilation systems research and features the research tasks formulated on the basis of said review to allow achieving the aim of the research.

Chapter 2 outlines the programme, methodology, and results of experimental research into turbine ventilators.

Chapter 3 describes the thermodynamic model of operation of the turbine ventilator as developed on the grounds of experimental research. It also contains a theoretical assessment of boosting the functionality of the turbine ventilator when the device can accumulate excess wind energy. 


\section{Žymëjimai}

\section{Simboliai}

$A$ - plotas;

$C$ - aerodinaminès traukos koeficientas;

$d$-skersmuo;

$E$ - energija;

$F-$ jèga;

$g$ - laisvojo kritimo pagreitis;

$h$ - entalpija arba aukštis;

$k$ - koeficientas;

$M$ - masé;

$P$ - slègis;

$Q$ - oro debitas;

$R$ - universalioji dujų konstanta;

$s$ - entropija;

$T$ - temperatūra;

$u$-vèjo greitis;

$v$ - oro srauto greitis; 
$w$ - plotis;

$\varepsilon$ - energijos dalis arba efektyvumas;

$\zeta$-aerodinaminio pasipriešinimo koeficientas;

$\eta$ - efektyvumo koeficientas;

$\pi$ - bedimensinis rodiklis, arba $\pi$;

$\rho$ - oro tankis;

$\tau$ - sukimo momentas;

$\omega$ - sukimosi dažnis.

\section{Indeksai}

'- idealus procesas;

$a$ - atmosfera;

$c$ - vèdinama patalpa;

$d$ - dinaminis slègis arba aerodinaminè trauka;

$d e$ - ištraukiamo oro srauto dinaminis slègis;

$d e j$ - dinaminis slègis ežektoriuje;

$d o$ - traukos jèga veikianti oro ištraukimo ortakị;

$d t$ - pilnutinè traukos jèga;

$d w$ - vèjo srauto dinaminis slègis;

$e-$ ištraukiamas oro srautas;

$e j-$ ežekcija;

ejs - aktyvaus srauto suspaudimas ežektoriuje;

$e r$ - reikalingas ištraukiamas oro srautas;

ex - termodinaminę sistemą paliekantis srautas;

$i$ - ištraukiamo oro ittekèjimo anga;

max - maksimumas;

$p$ - slègis arba savitoji šiluma;

$Q$ - oro debitas;

$r$ - rotorius;

$s-$ statinis slègis;

$s c$ - vèdinamos patalpos statinis slègis;

$s e$ - ištraukiamo oro srauto statinis slègis;

$S T V$ - stoginis turbininis ventiliatorius;

$s w$ - vejjo srauto statinis slègis;

$t$ - turbina;

te - pilnutinis slėgis ištraukiant oro srautą; 
tej-pilnutinis slègis dèl ežekcijos;

$t r$ - rotoriaus pridedamas pilnutinis slègis;

$t w$ - vèjo srauto pilnutinis slègis;

$v e$ - įrenginio skerspjūvio dalis statmena vèjo srautui;

$w$ - vèjo srautas;

$w i-\mathfrak{i}$ turbininio ventiliatoriaus vidų patekęs vèjo srautas;

$w l$ - nuo turbininio ventiliatoriaus atitrūkęs vejjo srautas;

$\omega$ - sukimosi dažnis.

\section{Santrumpos}

NCIL - Nacionalinè civilinès inžinerijos laboratorija;

SFD - skaičiuojamoji fluidų dinamika;

STV - stoginis turbininis ventiliatorius. 



\section{Turinys}

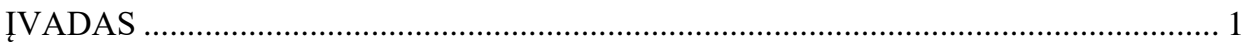

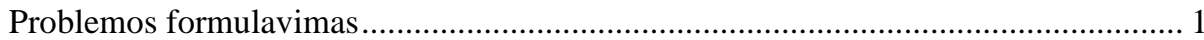

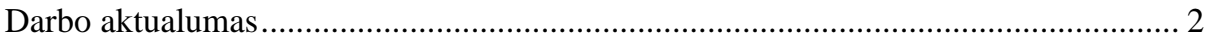

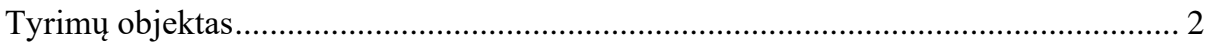

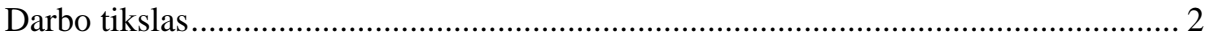

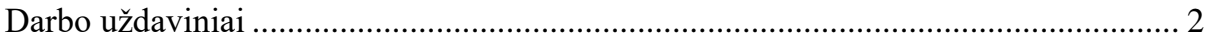

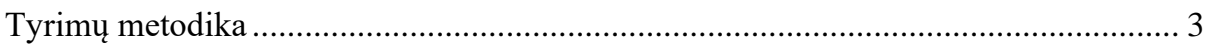

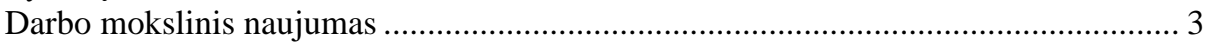

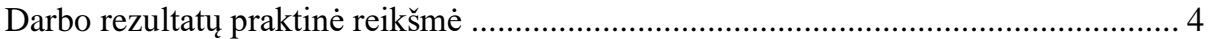

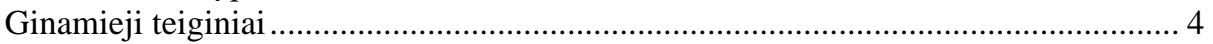

Darbo rezultatų aprobavimas............................................................................. 5

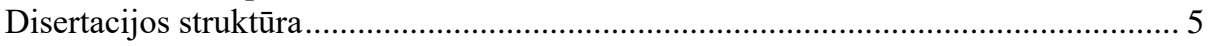

1. VĖJO ENERGIJĄ NAUDOJANČIŲ NATŪRALAUS VĖDINIMO SISTEMŲ

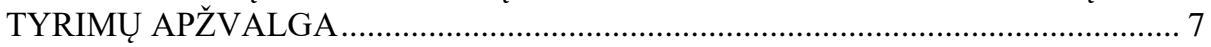

1.1. Natūralaus vẻdinimo technologinių sprendimų apžvalga ...................................... 8

1.1.1. Pasyvios natūralaus vèdinimo technologijos ................................................ 9

1.1.2. Aktyvios natūralaus vėdinimo technologijos ............................................. 16

1.2. Stoginių turbininių ventiliatorių tyrimų apžvalga................................................ 16

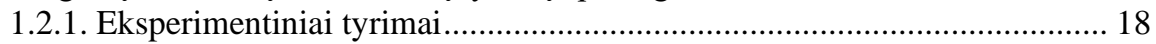

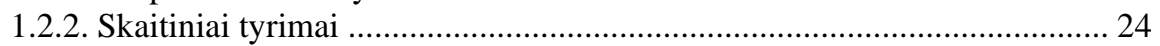

1.3. Stoginių turbininių ventiliatorių tyrimų suvestinè ............................................... 27

1.4. Pirmojo skyriaus išvados ir disertacijos uždavinių formulavimas ........................ 28 


\section{TURBININIŲ VENTILIATORIŲ MECHANINIAI IR AERODINAMINIAI}

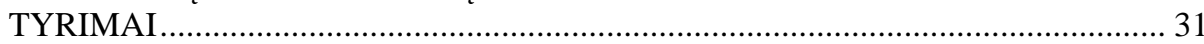

2.1. Eksperimentinių tyrimų programa ir bandomi ịrenginiai .................................... 31

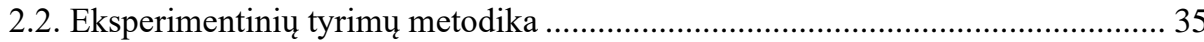

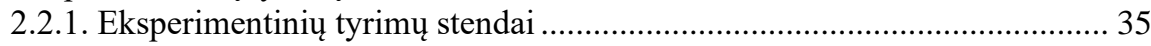

2.2.2. Ištraukiamo oro srauto ịvertinimas ........................................................... 39

2.2.3. Aerodinaminès traukos ir pasipriešinimo charakteristikų ịvertinimas ....... 41

2.2.4. Rotoriumi generuojamos galios ịvertinimas ............................................ 42

2.2.5. Eksperimentinių rezultatų neapibrèžtis ....................................................... 44

2.3. Eksperimentinių tyrimų rezultatai .................................................................... 46

2.3.1. Ištraukiamo oro srauto charakteristikos ………….................................. 46

2.3.2. Aerodinaminès traukos ir pasipriešinimo rodikliai ..................................... 54

2.3.3. Sukimo momento ir generuojamos galios charakteristikos......................... 57

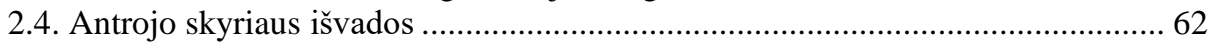

\section{TURBININIO VENTILIATORIAUS TRIKOMPONENTĖS KONCEPCIJOS}

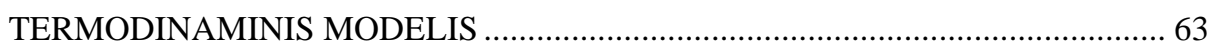

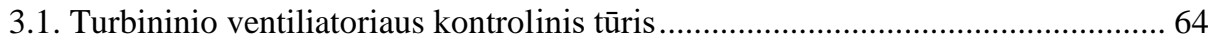

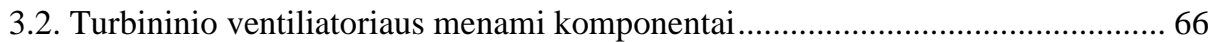

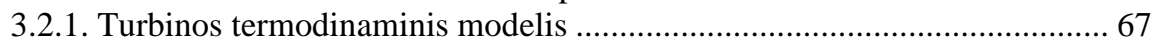

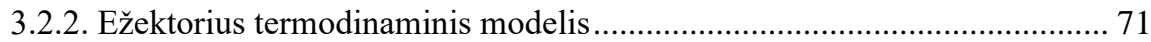

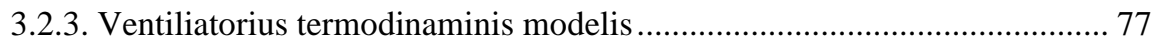

3.3. Menamų turbininio ventiliatoriaus komponentų veikimą integruojantis

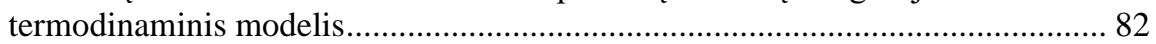

3.3.1. Turbininio ventiliatoriaus menamų komponentų tarpusavio sąveikos

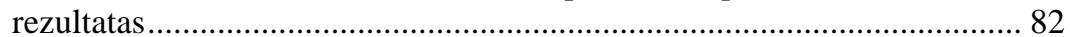

3.3.2. Teorinis turbininių ventiliatorių efektyvumo palyginimas.......................... 87

3.4. Turbininių ventiliatorių funkcionalumo padidinimo vertinimas ........................... 89

3.4.1. Perteklinès vèjo energijos akumuliavimo potencialo skaičiavimas ........... 93

3.4.2. Hibridinio vėdinimo funkcionalumo padidinimo teorinio skaičiavimo

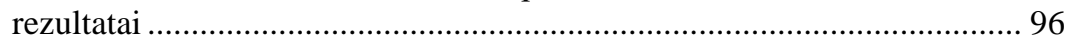

3.4.3. Akumuliuotos vèjo energijos naudojimo galimybès hibridinëje vėdinimo

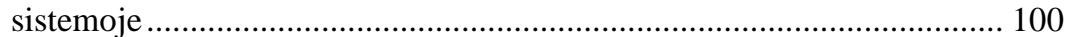

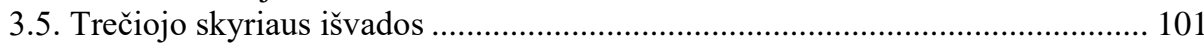

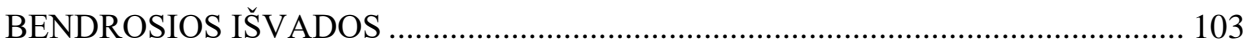

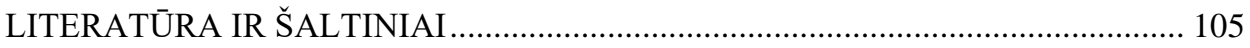

AUTORIAUS MOKSLINIŲ PUBLIKACIJŲ DISERTACIJOS TEMA SĄRAŠAS .. 111

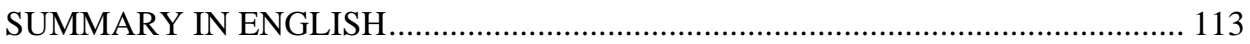


PRIEDAI ${ }^{1}$

A priedas. Sąžiningumo deklaracija ................................................................... 131

B priedas. Bendraautorių sutikimai teikti publikacijose skelbtą medžiagą daktaro

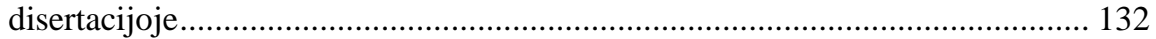

C priedas. Autoriaus mokslinių publikacijų disertacijos tema kopijos ...................... 138

${ }^{1}$ Priedai pateikiami pridètoje kompaktineje plokštelëje. 



\section{Contents}

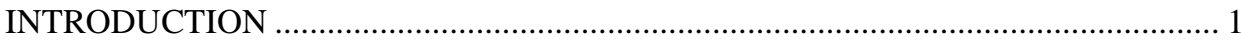

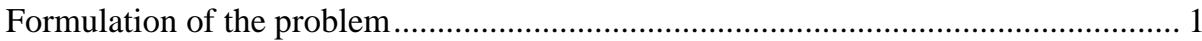

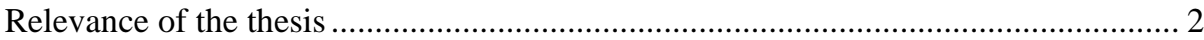

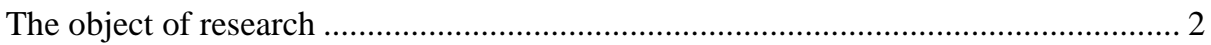

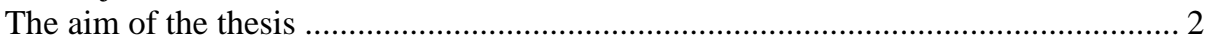

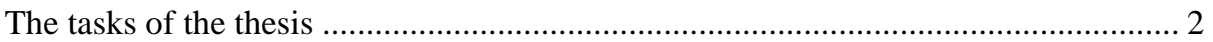

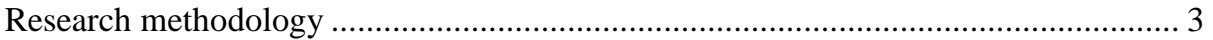

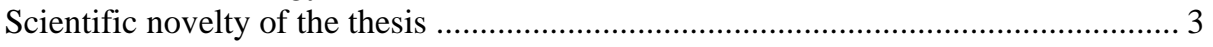

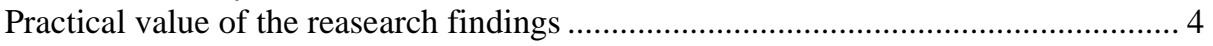

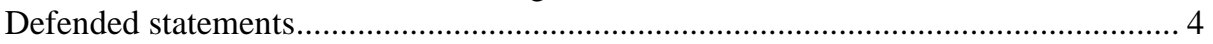

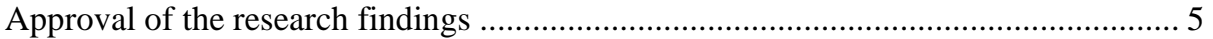

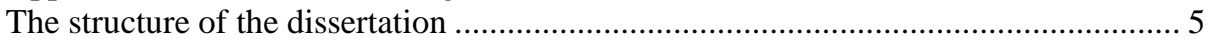

\section{REVIEW OF WIND DRIVEN NATURAL VENTILATION SYSTEMS}

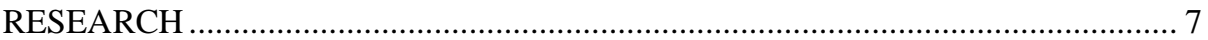

1.1. Review of natural ventilation technological solutions......................................... 8

1.1.1. Passive natural ventilation technologies ..................................................... 9

1.1.2. Active natural ventilation technologies.................................................... 16

1.2. Review of roof turbine ventilators research...................................................... 16

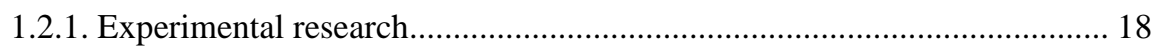

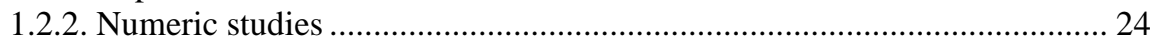

1.3. A summary of research of roof turbine ventilators ............................................ 27 
2. MECHANICAL AND AERODYNAMIC RESEARCH OF TURBINE

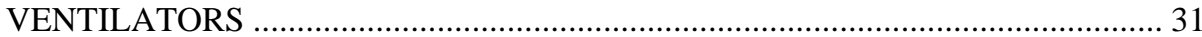

2.1. Experimental research programme and test devices ....................................... 31

2.2. Experimental research methodology ....................................................... 35

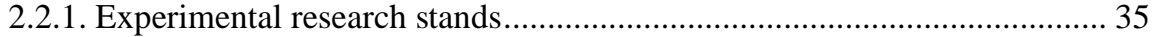

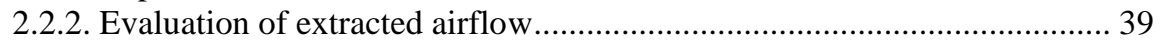

2.2.3. Evaluation of aerodynamic drag and minor dynamic loss ....................... 41

2.2.4. Evaluation of rotor generated power................................................. 42

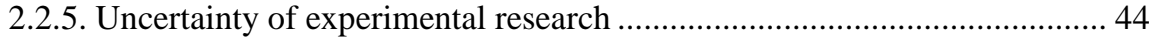

2.3. Experimental research results ..................................................................... 46

2.3.1. Extracted airflow characteristics .......................................................... 46

2.3.2. Aerodynamic drag and minor loss characteristics .............................. 54

2.3.3. Torque and generated power characteristics ......................................... 57

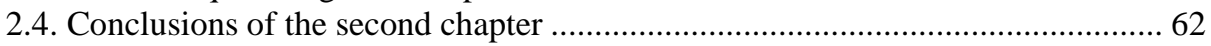

3. THERMODYNAMIC MODEL OF TRIPLE-COMPONENT CONCEPT OF

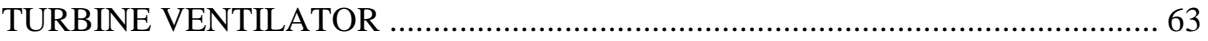

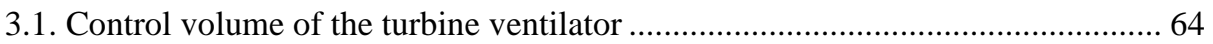

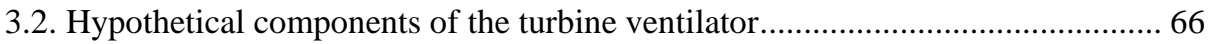

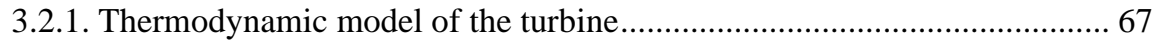

3.2.2. Thermodynamic model of the ejector .............................................. 71

3.2.3. Thermodynamic model of the ventilator........................................... 77

3.3. Thermodynamic model covering the operation of the hypothetical components

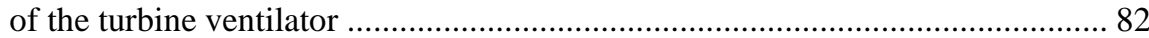

3.3.1. Result of the interaction of the hypothetical components of the turbine

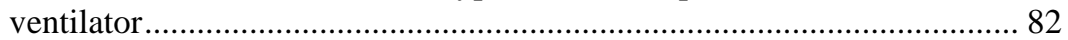

3.3.2. Theoretical comparison of the efficiency of turbine ventilators ............... 87

3.4. Assessment of increasing turbine ventilator functionality ............................. 89

3.4.1. Calculation for the potential to accumulate excess wind energy ............... 93

3.4.2. Theoretical calculation results for increasing hybrid ventilation

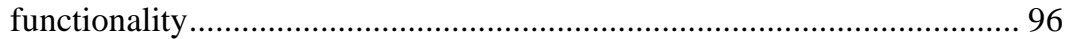

3.4.3. Possibilities to use accumulated wind energy in hybrid ventilation system .................................................................................... 100

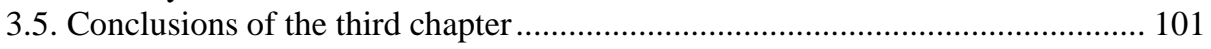

GENERAL CONCLUSIONS .......................................................................... 103

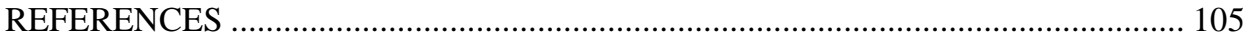

LIST OF SCIENTIFIC PUBLICATIONS BY THE AUTHOR ON THE TOPIC OF

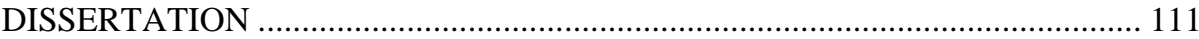

SUMMARY IN ENGLISH....................................................................... 113 
ANNEXES ${ }^{2}$

Annex A. Authors declaration of academic integrity ................................................. 131

Annex B.The co-authors' agreements to present publications material in the doctoral dissertation

Annex C. Copies of scientific publications by the author on the topic of the dissertation.

${ }^{2}$ The annexes are supplied in the enclosed compact disc. 



\section{Ivadas}

\section{Problemos formulavimas}

Šiuolaikinių pastatų vėdinimo sistemose veikiantys elektriniai ventiliatoriai naudoja didelę dali pastatams reikalingos energijos. Siekiant sumažinti energijos vartojimą būtina ieškoti naujų sprendimų, kurie užtikrintų aukštą vėdinimo sistemų efektyvumą ir reikiamą oro kokybę. Vienas iš galimų būdų atsinaujinančią energiją naudojančių technologijų taikymas. Atsinaujinantys energijos ištekliai tampa neatsiejamu šiuolaikinių technologijų energijos šaltiniu, tačiau beveik visos jų formos turi esminę problemą - neužtikrina poreikius atitinkančio stabilaus energijos srauto. Dèl šios priežasties, daugelis tokių sistemų negali užtikrinti reikiamo vẻdinimo funkcionalumo.

Šiuo metu plačiai paplitę vejjo energiją naudojantys stoginiai turbininiai ventiliatoriai (STV). Ankstesnių mokslinių tyrimų apžvalga rodo, jog trūksta tyrimų, universaliai aiškinančių srautinių oro procesų įtaką turbininių ventiliatorių efektyvumui bei nèra tokius įrenginius vienijančio teorinio veikimo modelio. Analizuojant vėdinimo funkcionalumą padidinančių hibridinių sistemų tyrimus pastebima, kad apsiribojama juos tobulinti integruojant elektrinį ventiliatorių, ar integruojant saulès elementus, tačiau nevertinamas turbininių ventiliatorių sezoninis veiksmingumas ir netiriamas vejjo energijos akumuliavimo potencialas, esant perteklinei vejjo energijai. 


\section{Darbo aktualumas}

Oro srautų procesai turbininiuose ventiliatoriuose yra sudètingi, todèl jų efektyvumo ir funkcionalumo vertinimui atliekami ilgai trunkantys kiekybiniai ir kokybiniai tyrimai. Šio darbo pirmine hipoteze teigiama, kad turbininiuose ventiliatoriuose vykstantys procesai savyje apjungia procesus vèjo turbinose, ežektoriuose bei ventiliatoriuose. Ji vystoma kuriant írenginio veikimo termodinaminio modelio koncepciją, kuria galima įvertinti srautinių procesų sąveiką minètuose trijuose komponentuose, ją taikyti turbininių ventiliatorių tobulinimui. Tokios koncepcijos pagrindu parengtas modelis darbe kryptingai testuojamas eksperimentiniais tyrimais.

Siekiant ịrenginius kiekybiškai palyginti plačiame veikimo diapazone, šiame darbe vejjo energiją naudojančių ventiliatorių ištraukiamo oro charakteristikos nustatomos esant ne tik skirtingiems vejjo greičiams, bet ir aplinkos statinio slègio sąlygoms. Be to, analizuojant turbininius ventiliatorius atliekami retai pasitaikantys generuojamos galios ir aerodinaminių charakteristikų bandymai.

Hibridinių vẻdinimo sistemų tyrimų apžvalga rodo, jog ieškoma sprendimų, kaip padidinti vėdinimo funkcionalumą, kai nepakanka vëjo srauto turbininiam ventiliatoriui veikti nominaliu režimu. Tačiau trūksta mokslinių tyrimų apie perteklinès vejjo energijos akumuliavimo galimybes tokiose sistemose. Šiame darbe vertinamas energijos kaupimo potencialas ir jos panaudojimas védinimo funkcionalumui padidinti.

\section{Tyrimų objektas}

Darbo tyrimų objektas - vejo energiją naudojantys stoginiai turbininiai ventiliatoriai, jų veikimas, efektyvumas, funkcionalumas.

\section{Darbo tikslas}

Parengti eksperimentiškai nustatomomis mechaninèmis ir aerodinaminèmis charakteristikomis paremtą turbininio ventiliatoriaus teorinị veikimo modelį.

\section{Darbo uždaviniai}

Darbo tikslui pasiekti sprendžiami šie uždaviniai: 
1. Apžvelgtų mokslinių tyrimų pagrindu parengti ir ịvykdyti eksperimentinių tyrimų programą, kuria struktūrizuojami STV

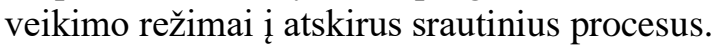

2. Kiekybiškai ir kokybiškai palyginti skirtingu STV eksperimentines sukimo momentų, dažnių, galių ir oro srautų charakteristikas, nustatyti jų empirines lygtis ir palyginti su teorinèmis lygtimis.

3. Atsižvelgiant ì eksperimentinių tyrimų rezultatus, pasiūlyti STV konstrukciją ir tekèjimo procesus atspindinčią struktūrinio suskaidymo koncepciją, kuri būtų palanki procesų termodinaminio modelio formavimui.

4. Parengti pasirinktu STV komponentu integruojantị veikimo termodinaminị modelị ir ji pagrịstai susieti su eksperimentinių tyrimų rezultatais.

5. Ivvertinti galimybes padidinti vejo energijos panaudojimo efektyvumą STV, esant stochastiniam vejjo kitimui metų cikle.

\section{Tyrimų metodika}

Darbe pristatyti eksperimentiniai tyrimai atlikti Vilniaus Gedimino technikos universiteto (Vilnius Tech) laboratorijoje ir Portugalijos Nacionalinèje civilinès inžinerijos laboratorijoje (NCIL). Tyrimai laboratorijose atlikti vèjo tuneliuose, atsižvelgiant i tarptautinius STV bandymo standartus „EN 13141-5“, „AS/NZS 4740:2000“ bei remiamasi mokslinèse publikacijose pateiktų eksperimentinių tyrimų idejjomis. Imituojant skirtingas irrenginių veikimo sąlygas, bandymų stenduose keičiami vejjo greičiai, statiniai slègiai, STV rotoriaus apkrovos. Tyrimo rezultatams apdoroti ir palyginti taikoma sisteminè analizè, kuri apjungia darbe taikomus statistinius, bedimensinius, termodinaminius ir kitus metodus.

Rengiant termodinaminę STV veikimo modelio koncepciją taikoma termodinaminè analizè, kokybiškai ir kiekybiškai nustatytos procesų priklausomybės grindžiamos eksperimentų rezultatais. Skaičiuojant metinius rodiklius naudojami „Meteonorm“ programos vejjo greičio duomenys.

\section{Darbo mokslinis naujumas}

Rengiant disertaciją buvo gauti šie mechanikos inžinerijos mokslui nauji rezultatai: 
1. Eksperimentiniuose tyrimuose pritaikytas integralus bandymų metodas, leidžiantis įvertinti bandytų trijų skirtingų STV vėdinimo funkcionalumą, generuojamą galią ir aerodinaminị pasipriešinimą. Bandytiems įrenginiams nustatytos empirinès charakteristikų lygtys.

2. Taikant bedimensinę analizę, kiekybiškai ir kokybiškai palyginti dviejų skirtingų vejjo energiją naudojančių deflektorių bei trijų STV ištraukiamo oro srautai, esant skirtingoms vejjo greičio ir aplinkos statinio slègio sąlygoms.

3. Susiejus eksperimentinių tyrimų rezultatus, darbe pristatyta vejjo energiją naudojančio STV ežektoriaus, turbinos ir stoginio ventiliatoriaus veikimą integruojanti koncepcija, kuri išreikšta integraliu oro srautų sąveikos termodinaminiu modeliu. Tokios koncepcijos pagrindu sukurtas modelis leidžia kokybiškai ir kiekybiškai įvertinti STV veikimo metu sąveikaujančių srautinių procesų poveikį ịrenginio funkcionalumui, nustatyti efektyvumą bei teorinị tobulinimo potencialą.

4. Remiantis eksperimentinių tyrimų rezultatais ir statistiniais metinio vejjo greičio kitimo duomenimis - įvertintas teorinis STV ištraukiamo oro srauto, energijos akumuliavimo, funkcionalumo padidinimo potencialas hibridinèje vėdinimo sistemoje.

\section{Darbo rezultatų praktinė reikšmè}

Šiame darbe pateikta vejo energiją naudojančio STV daugiakomponentė koncepcija, kurios išreiškimas termodinaminio modeliu pagrindu leidžia kokybiškai ir kiekybiškai identifikuoti atskirus STV veikiančius srautus, ịvertinti jų poveikị įrenginio funkcionalumui, nustatyti efektyvumą bei teorinị tobulinimo potencialą. Eksperimentinių tyrimų rezultatai naudingi kuriant atsinaujinančią vejjo energiją naudojančias hibridinio vėdinimo sistemas bei vertinant tokių sistemų veiksmingumą akumuliuojant perteklinę vėjo energiją. Teorinio skaičiavimo rezultatai ir pristatyta metodika gali būti taikoma védinimo funkcionalumo padidinimo vertinimui.

\section{Ginamieji teiginiai}

1. STV funkcionalumas labai priklauso nuo statinio slègio sąlygų, todèl šių ịrenginių pasirinkimas neturètu apsiriboti charakteristiku vertinimu tik pagal vèjo greitị. 
2. Trijų komponentų struktūrinio suskaidymo koncepcija išreikštas integruojantis termodinaminis STV modelis leidžia ịvertinti vejjo energiją naudojančių STV oro srautų sąveiką, šių ịrenginių tobulinimo galimybes.

3. Platus STV charakteristikų pažinimas leidžia įvertinti generuojamos perteklinès energijos akumuliavimo galimybes, padidinti kintančią vejjo energiją naudojančių hibridinių vėdinimo sistemų funkcionalumą.

\section{Darbo rezultatų aprobavimas}

Disertacijos tema paskelbti 8 straipsniai: du - Clarivate Analytics Web of Science duomenų bazėse referuojamuose leidiniuose, turinčiuose citavimo rodiklį (Rimdžius et al., 2021; Martinaitis et al., 2020); keturi - tarptautinių konferencijų leidiniuose, referuojamuose Clarivate Analytics duomenų bazeje Proceedings (Rimdžius et al., 2018; Streckiené et al., 2021; Streckiené et al., 2018; Januševičius et al., 2017), vienas - kitų tarptautinių duomenų bazių leidiniuose (Rimdžius \& Bielskus, 2018), vienas - konferencijų pranešimų medžiagoje (Sketerskis, Rimdžius, \& Martinaitis, 2018). Europos patentų biure įregistruotas patentas (Martinaitis et al., 2021). Lietuvos Respublikos valstybiniame patentų biure ịregistruoti du patentai (Martinaitis et al., 2021, Martinaitis et al., 2019).

Disertacijos tema perskaityti 3 pranešimai tarptautinèse konferencijose Lietuvoje ir Vokietijoje:

- Tarptautineje konferencijoje Lietuvoje „10th International Conference „Environmental Engineering“ 2017 m. Vilniuje;

- Du pranešimai tarptautinejje konferencijoje Vokietijoje „The 3rd International Conference on Power and Renewable Energy (ICPRE 2018)“ $2018 \mathrm{~m}$. Berlyne.

\section{Disertacijos struktūra}

Disertaciją sudaro įvadas, trys skyriai ir bendrosios išvados. Taip pat yra trys priedai.

Darbo apimtis yra 129 puslapiai, neskaitant priedų, tekste panaudotos 76 numeruotos formulès, 57 paveikslai ir 6 lentelès. Rašant disertaciją buvo panaudoti 73 literatūros šaltiniai. 



\section{1}

\section{Vèjo energiją naudojančių natūralaus vèdinimo sistemų tyrimų apžvalga}

Natūralus vėdinimas yra vienas iš esminių faktorių projektuojant energiškai efektyvius pastatus. Daugeliu atveju natūralus védinimas apima natūralias vejjo ir gravitacijos jègas, kuriomis šviežias oras tiekiamas ị pastato patalpas. Pagal védinimo būdą, natūralus védinimas gali būti suskirstytas ị pasyvias ir aktyvias vèdinimo technologijas.

Šiame skyriuje apžvelgiamos pagrindinès natūralaus vėdinimo rūšys, jų privalumai, trūkumai, taikymo galimybès, mokslinių tyrimų kryptys. Detaliau pristatomi stoginiai turbininiai ventiliatoriai bei jų eksperimentiniai ir skaitiniai tyrimai. Remiantis sudaryta tyrimų suvestine, pateikiama temos problema bei formuluojami disertacijos uždaviniai.

Skyriaus tematika paskelbtos trys publikacijos (Rimdžius et al., 2018; Rimdžius \& Bielskus, 2018; Sketerskis, Rimdžius, \& Martinaitis, 2018). 


\subsection{Natūralaus vėdinimo technologinių sprendimų apžvalga}

Jau daugelị amžių natūralus vėdinimas yra pagrindinis būdas pastatų vėdinimui ir iki šiol jis vis dar išlieka daugelio senos statybos pastatu pirminiu védinimo šaltiniu. McQuiston ir Parker teigimu šis vėdinimo būdas vyrauja gyvenamosios paskirties pastatuose (Faye C. McQuiston, Jerald D. Parker, 2005). Iprastai tokiuose pastatuose natūralus vėdinimas vyksta atveriant langus, orui tekant specialiai numatytomis angomis ir išorinių atitvarų nesandarumais. Visgi, natūralus vẻdinimas turi esminių funkcionalumo problemų dèl šių pagrindinių priežasčių: nepastovios temperatūros pastato viduje ir išorèje, vẻjo greičio kitimas. Tai ypač nepalanku laikotarpiais, kai susidaro kritinès temperatūros ir vëjo greičio sąlygos, vyksta dideli šių veiksnių svyravimai. Vienu atveju vėdinimas gali būti per didelis, kitu atveju per mažas, ar net sukelti tokias pasekmes kaip vėdinimo srauto tekèjimas ị priešingą pusę (Welsh, 1994). Dẻl šių priežasčių, natūraliu vėdinimu paremti technologiniai sprendimai, iprastai reikalauja papildomų mechaninių vėdinimo sistemų.

Kita vertus, didejjant modernizuotų ir šiuolaikinių pastatų sandarumui - vis dažniau susiduriama su pablogejjusios oro kokybès problema (Gill et al., 2021). Be to, didèja reikalavimai oro kokybei, šiuolaikinių pastatų védinimui suvartojama energija užima didelę dalị visos pastate suvartojamos energijos (Kitzberger et al., 2018; Piselli et al., 2020). Šios ir kitos priežastys veda prie atsinaujinusio susidomėjimo natūraliu vėdinimu bei naujų sprendimų paieškos (Khan, Su, \& Riffat, 2008).

Natūralus vėdinimas vis dažniau ịvardinamas kaip alternatyvus būdas mechaniniam vėdinimui ir vėsinimui. Natūralaus vėdinimo sprendimai tampa ypač aktualūs projektuojant energiškai efektyvius pastatus, sumažinant mechaninio vẻdinimo poreikị. Nauji moksliniai tyrimai rodo, jog natūralaus vėdinimo technologijos turi didžiuli neišnaudotą potencialą pastatų vėdinimui ir tam turètų būti skirta daugiau dèmesio lyginant su mechaniniu vẻdinimu (Jones et al., 2016). Daugelis tyrejjų ieško būdų kaip ịgyvendinti natūralaus vėdinimo sprendimus, kurie užtikrintų ne tik mažesnes energijos sąnaudas, bet ir išlaikytų reikiamą oro kokybę, arba ją pagerintų (Lukiantchuki et al., 2020). Izadyar atliktas tyrimas rodo, jog didžiausias natūralaus vėdinimo potencialas pastebimas aukštuose bei vidutinio aukštumo pastatuose (Izadyar et al., 2020).

Natūralus vẻdinimas dažniausiai apibūdinamas kaip procesas, kurio metu šviežias oras yra tiekiamas i patalpas nenaudojant jokios mechaninès sistemos energijos. Natūralaus vẻdinimo metu vyrauja du fundamentalūs principai: gravitacijos jëga ir vejjo varomas oro srautu judèjimas (Haw et al., 2012; Jomehzadeh et al., 2020; Park et al., 2017). Fizikine prasme tai yra oro slégio skirtumo ir oro tankio skirtumo rezultatas. Šios skirtingos prigimties jëgos 
dažniausiai veikia vienu metu ir tam tikrais atvejais gali būti priešingų krypčių, arba veikdamos sinergijoje viena kitą sustiprinti.

Gravitacijos jèga susidaro dèl oro temperatūrų skirtumo tarp pastato vidaus ir išorès (Han et al., 2018). Kai pastato vidaus oro temperatūra yra didesnè už lauko oro temperatūrą, šiltas vidaus oras kyla aukštyn ir yra pakeičiamas kitu, šaltesniu ir tankesniu oro iš apačios, kuris ịprastai infiltracijos būdu iš lauko patenka pro pastato angas. Natūralus védinimas dèl gravitacijos jègos yra žymus tais laikotarpiais, kai yra mažas vejjo greitis bei didelis pastato vidaus ir išorès oro temperatūrų skirtumas (Yuan \& Glicksman, 2008).

Vejjo varomas vėdinimas priklauso nuo vejjo greičio, krypties, pastato geometrijos, natūralaus vėdinimo ịrenginių tipo ir kitų faktorių (Chu \& Wang, 2010; van Hooff et al., 2011). I pastato atitvaras pučiantis tiesioginis vėjo srautas sukuria padidèjusi slègi. Tuo tarpu priešingoje pastato pusėje susidaro mažesnis slègis. Šis, tarp skirtingų pastato pusių susidaręs slègio skirtumas, sudaro sąlygas natūraliam vėdinimui (Wu et al., 2021). Kita vertus, vejo srautui sąveikaujant su natūralaus vėdinimo įrenginiais, pastatų vėdinimas tiesiogiai priklauso nuo įrenginių veikimo principo. Vèjo srautas gali būti tiesiogiai išnaudojamas oro pasiurbimui iš vėdinimo kanalo ežekcijos būdu (Wills et al., 1959), arba vejjo srauto energija gali būti naudojama ventiliatoriams sukti.

Iprastai, natūralaus vėdinimo technologijos pagal savo veikimo principą klasifikuojamos i pasyvias ir aktyvias (M. Ismail \& Abdul Rahman, 2010; J. Lien, 2002). Toliau esančiuose poskyriuose apžvelgiamos pagrindinès pasyvios ir aktyvios vèjo energiją naudojančios sistemos.

\subsubsection{Pasyvios natūralaus vèdinimo technologijos}

Iprastai laikoma, jog prie pasyvių vėjo varomo vėdinimo technologijų priskiriami sprendimai, kurie neturi judančių detalių. Dažnu atveju tai gali būti pastato architektūriniai sprendimai, papildomi statiniai ir irenginiai montuojami ant pastato stogo ar sienų (Chan et al., 2013). Vienas paprasčiausių ir visiems puikiai pažistamas pasyvioms védinimo technologijoms priskiriamas pastato architektūrinis sprendimas - langai. Tinkamai parinktos langų angų vietos bei jų dydžiai yra itin svarbūs faktoriai ne tik pastato natūraliam apšvietimui, bet ir natūraliam vẻdinimui. Toliau, šiame poskyryje apžvelgiamos kelios populiarios pasyvios natūralaus vėdinimo technologijos.

Dažnu atveju kitas pasitaikantis natūralaus vėdinimo architektūrinis sprendimas - atriumai. Tai specifiniai, ịprastai negyvenamosios paskirties pastatų architektūriniai sprendimai, kurie ịrengiami pastato centrinèje ar kraštinèje dalyje. Konstrukciškai atriumai yra didelès skaidrių atitvarų erdvès su viršuje ịrengtomis oro ištekejjimo angomis ir sujungti su pastato koridoriais, ar kitomis pastato patalpomis (1.1 pav.). 
Atriumais sukuriama natūralaus vėdinimo trauka tiesiogiai priklauso nuo besikeičiančių varomosios jègos sąlygų. Istorinè patirtis ir atlikti tyrimai rodo,jog atriumai labiau efektyvūs dideliuose ir aukštuose pastatuose (Acred \& Hunt, 2013; Moosavi et al., 2014).

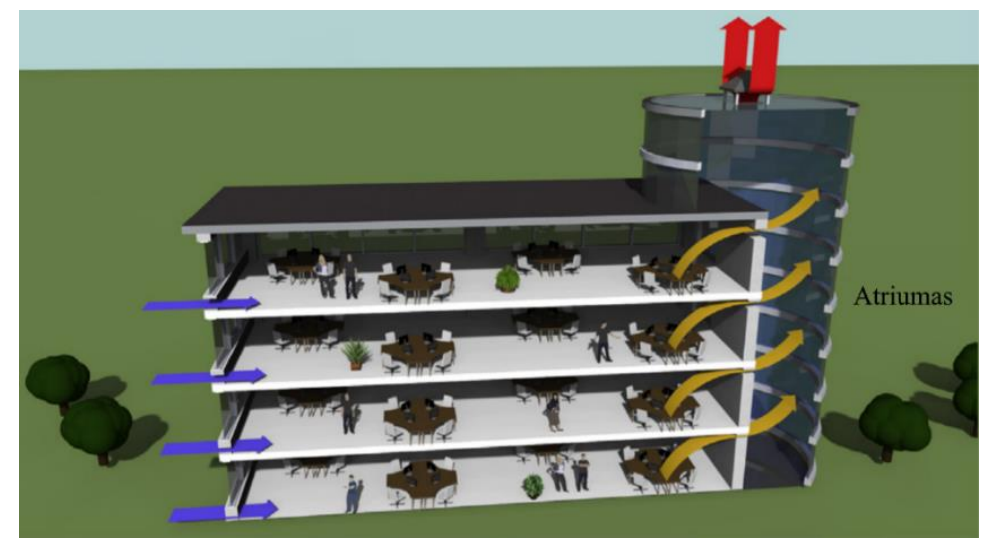

1.1 pav. Natūralus vėdinimas pastato atriumu (Acred \& Hunt, 2013)

Fig. 1.1. Natural ventilation in atrium building (Acred \& Hunt, 2013)

Pagrindiniai faktoriai lemiantys natūralaus vėdinimo trauką yra gravitacijos efektas, priklausantis nuo temperatūros skirtumo tarp pastato vidaus ir išorès, bei lauke pučiamo vejo greičio. Mokslinèje literatūroje minima, jog atriumai dažniausiai projektuojami atsižvelgiant i vyraujančius ir prognozuojamus temperatūros skirtumus tarp pastato vidaus ir išorès (Lomas \& Ji, 2009). Pastarieji priklauso tiek nuo vidinių šilumos pritekių, tiek nuo išorinių saulès pritekių. Tuo tarpu vejjo srauto poveikis vertinamas kaip galima didelè papildoma varomoji natūralaus vẻdinimo jèga, tačiau ji yra nenuspejjama. Dèl šios priežasties, védinimas yra nekontroliuojamas. Horan ir Finn atlikto tyrimu metu nustatyta, jog atriumių natūralaus vėdinimo trauka turi tiesinę priklausomybę nuo vẻjo greičio (Horan \& Finn, 2008).

Kitas galimas architektūrinis sprendimas, leidžiantis išnaudoti vejjo energiją pastato vėdinimui - sparno siena (angl. wing wall). Šis architektūrinis sprendimas leidžia pagerinti vėdinimą tais atvejais, kai pastato patalpos turi védinimo angas tik vienoje pusejje bei nèra galimybès sukurti skersvejo pro skirtingas pastato sienas (Jomehzadeh et al., 2020).

Iprastai, šis védinimo būdas taikomas pasitelkiant langus, kurių orientacija sutampa su pučiamo vejjo kryptimi. Tačiau norint pagerinti efektyvumą, ties patalpos langais papildomai suformuojami išsikišusios konstrukcijos elementai (1.2 pav.), kurie pučiant vejui, padidina teigiamo ir neigiamo slègio zonas ties 
langais ir tokiu būdu padidina oro trauką (Elwan et al., 2018). Pasak Mak, toks sprendimas patalpoje leidžia pasiekti vėdinimo srauto greiț, kuris gali siekti iki $40 \%$ pučiamo vejjo greičio (Mak et al., 2007). Tuo tarpu be šių išsikišusios konstrukcijos elementų patalpoje galima pasiekti tik iki $15 \%$ vejjo greičio. Nors sparno sienos yra gana efektyvus vėdinimo sprendimas, jų taikymas gana retas dèl riboto integravimo galimybių i pastatų architektūrinius sprendimus. Ypatingai dẻl to, kad jie sumažina šviesios pateikimą ị patalpą (Khan, Su, \& Riffat, 2008).

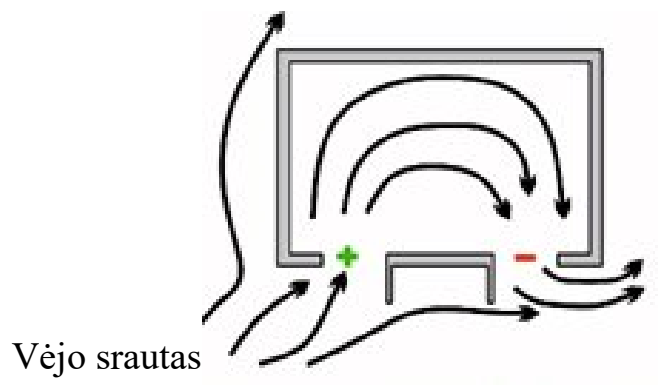

1.2 pav. Sparno sienos veikimo principo schema (Elwan et al., 2018)

Fig. 1.2. Scheme of the operation principle of the wing wall (Elwan et al., 2018)

Siekiant kartu išnaudoti vejjo ir gravitacijos jëgas, prie pastatų galima ịrengti - vejjo bokštą (angl. wind tower). Tai dažniausiai yra atskiras pastato statinys, suskirstytas i dvi atskiras sekcijas. Pučiantis vèjo srautas gali ịtekèti per tos sekcijos angą, kuri yra atsukta ị vejjo pusę (1.3 pav. a). Ši sekcija yra vadinama teigiamo slègio zona. Bokštu pratekèjęs oras atitinkamai pasiskirsto į žemesnio slėgio zonas. Oro srautas gali ištekèti per kitą bokšto angą arba per pastato angas. Tokiu būdu vyksta oro srautų maišymasis ir sukuriamas skersvejjis (Varela-Boydo \& Moya, 2020).

Esminiai faktoriai tokio sprendimo veikimui yra ties bokšto angomis pučiamo vejjo srauto kampas ir užuovejjos anga bokšte, kuri gali sumažinti oro ištekejjimo greiti. Visgi, atliktos studijos parodè, jog šiuo vėdinimo sprendimu labai sunku reguliuoti ištraukiamo oro srautą ir tokie statiniai netinka vietovėse, kur yra mažas vejo greitis (Karakatsanis et al., 1986). Be to, tarp trūkumų îvardijamos problemos dèl dulkių kaupimosi bei statiniuose gali veistis vabzdžiai. Naujesnès studijos parodè, kad tokiems statiniams naudinga irengti automatines sklendes, kurios reguliuotų bokšto angų dydị. Taip pat, bokštai gali būti patobulinti kartu naudojant orinius saulès kolektorius, kurie leistų padidinti gravitacijos sukuriamą trauką ir tokiu būdu vėdinimas vyktų esant ir mažiems vejjo greičiams (Nouanégué et al., 2008).

Panašiam veikimo principui $\mathfrak{i}$ vejjo bokštus priskiriami dvigubi fasadai (Pourshab et al., 2020). Naudojant tokius sprendimus sukuriamas skersvèjis, kurio 
pagrindinè varomoji jèga yra vejjas bei gravitacija. Saulès spinduliuotè, šildydama oro srautą dvigubame fasade, sukuria gravitacijos efektą. Tuo tarpu vejjo srautas sukurdamas slègių skirtumą priešingose fasadų pusèse ši efektą padidina (1.3 pav. b). Panašiai kaip ir vejjo bokštų atveju, nustatyta, kad vejo greitis ir kryptis yra labai svarbūs faktoriai, lemiantys dvigubų fasadų natūralaus vėdinimo efektyvumą.

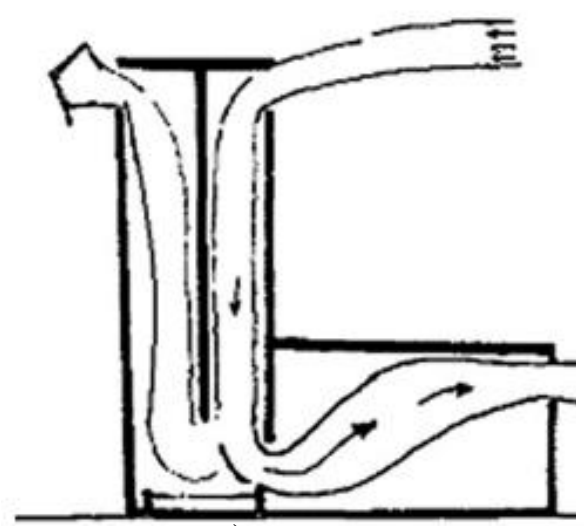

a)

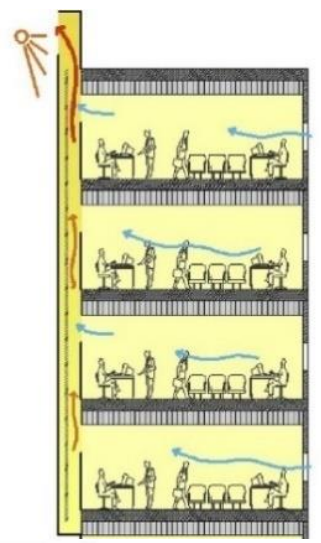

b)

1.3 pav. Vèjo bokšto ir dvigubo fasado veikimo principų palyginimas: a) vėjo bokštas

(Khan, Su, \& Riffat, 2008); b) dvigubas fasadas (Pourshab et al., 2020)

Fig. 1.3. Comparison of the operation principle of wind tower and the double-skin facade: a) wind tower (Khan, Su, \& Riffat, 2008); b) double-skin facade (Pourshab et al., 2020)

Kitas įrenginys turintis panašumų $\mathfrak{i}$ anksčiau minètas vėdinimo technologijas - vèjo gaudyklè (angl. windcatcher). Vejjo gaudyklès (1.4 pav.) yra ant pastato stogo montuojami įrenginiai, kurie tiekia šviežią orą ị patalpas ir ištraukia užterštą orą, kartu veikiant vejo slègio ir gravitacijos jẻgoms (Jomehzadeh et al., 2020). Vèjo gaudyklès pasižymi tuo, kad gali ịtraukti vejjo srautą pastato stogo lygyje ir toliau nukreipti i pastato vidų bei tokiu būdu, tuo pačiu ištraukti orą iš užuovejos zonų. Be to, tokio ịrenginio privalumas - galimybė vėdinti kelių aukštų pastatus. Chong ịvertino tokių ịrenginių našumą ir nustatė, kad vèjo gaudyklèmis ịtekančio oro greitis ị patalpą yra panašus ị pučiamo vèjo greitị (Chong et al., 2016). 


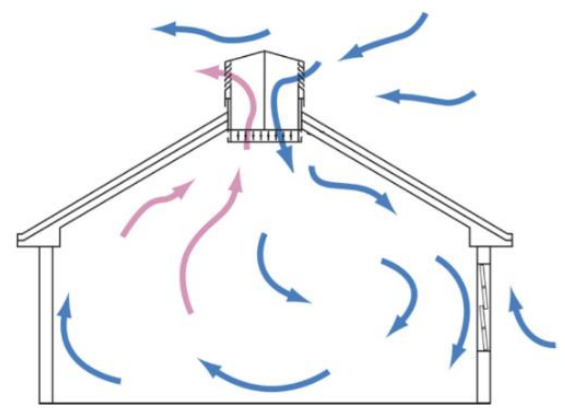

1.4 pav. Vëjo gaudyklès veikimo principo schema (Monodraught, 2020)

Fig. 1.4 Scheme of the operation principle of the windcatcher (Monodraught, 2020)

Oro ištraukimo metu, vėdinimo trauka vėjo gaudyklèse susidaro dèl ịrenginyje susidarančių gravitacijos bei vejjo srauto jègų. Dèl šių jègų pastato viduje ir išorèje susidaręs slègio ir temperatūrų skirtumas verčia patalpos orą kilti aukštyn, ir ištekèti per specialius įrenginio kanalus (Liu Li, 2007). Tokia sistema dažniausiai yra sudaryta iš keturių kanalų: šviežio oro įtekèjimo kanalo, šalinamo oro kanalo, i pastatą tiekiamo oro kanalo, iš pastato ištraukiamo oro kanalo. Šviežio oro įtekejjimo ir šalinimo oro kanalų kryptis gali kisti priklausomai nuo vejjo krypties. Ši savybè leidžia sumažinti priklausomybę nuo vejjo sąlygu ir nereikia keisti įrenginio krypties (Zaki et al., 2019). Elmualim atliktais skaitiniais tyrimais nustatyta, kad veikiant tik vejo gaudyklei, susidaro gana maža trauka, tačiau atidarius langus, trauka padidèja ženkliai (Elmualim, 2006).

Kitas itin plačiai ant pastato stogo montuojamas įrenginys - deflektorius (1.5 pav.). Stoginiai deflektoriai pasižymi nesudetinga konstrukcija ir yra itin dažna priemonè pagerinanti natūralų pastatų vẻdinimą. Šie sprendimai skirti ne tik pagerinti natūralų védinimą, bet tuo pačiu apsaugo nuo priešingos krypties oro traukos, lietaus, paukščių, vabzdžių ir kitų nepageidaujamų veiksnių patekimo ị pastatą (Wills et al., 1959). Deflekorių veikimas paremtas gravitacijos jègomis bei ežekcija. Pastarasis reiškinys susidaro kai vejjo srautas statmena kryptimi prateka virš oro ištraukimo kanalo ir tokiu būdu šioje vietoje sudaro žemo slègio zoną. Dẻl šios priežasties, susidaro sąlygos oro pasiurbimui ežekcijos būdu.

Tokių ịrenginių tyrimai rodo, kad jais siurbiamas oro kiekis priklauso nuo vejo greičio ir krypties (Pfeiffer et al., 2008). Planuojant deflektorių ịrengimą svarbu atsižvelgti, kad nebūtų kliudoma oro srauto tekejimui. Kitu atveju labai sumažeja ištraukiamo oro trauka. 


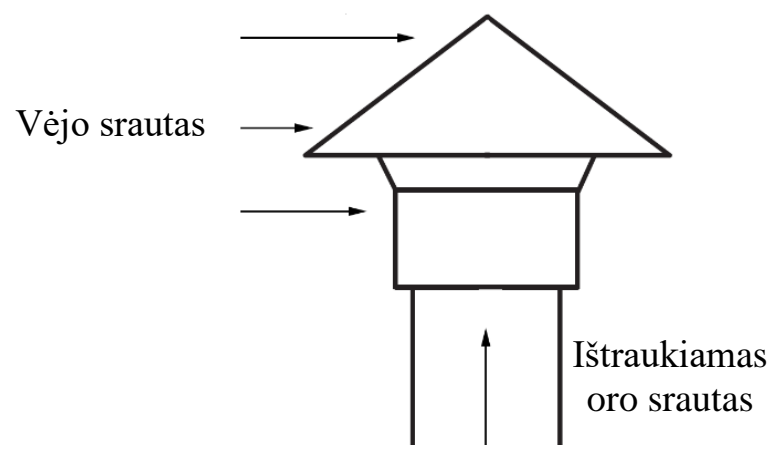

1.5 pav. Stoginio deflektoriaus veikimo principo schema (Pfeiffer et al., 2008)

Fig. 1.5. Scheme of the operation principle of the rooftop deflector (Pfeiffer et al., 2008)

$2008 \mathrm{~m}$. atliktas kompiuterinis modeliavimas rodo, jog vëjo srauto kryptis yra kritinis faktorius šių įrenginių efektyvumui (Pfeiffer et al., 2008). Tyrimai rodo, kad tokie stacionarūs įrenginiai turi ribotas vejjo energijos išnaudojimo galimybes. Tuo tarpu aktyvaus tipo įrenginiai vèjo potencialą turètų išnaudoti geriau.

Prie pasyvių vèjo energiją naudojančių vėdinimo technologijų gali būti priskiriami ir reguliuojamos krypties deflektorius (1.6 pav.). Khan et al. šiuos ịrenginius klasifikuoja kaip kryptines vèjo varomo vėdinimo technologijas (Khan, $\mathrm{Su}, \&$ Riffat, 2008).

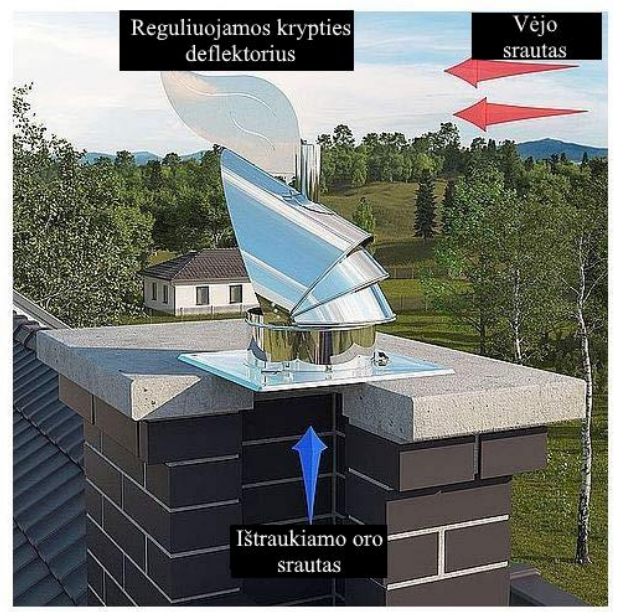

1.6 pav. Reguliuojamos krypties deflektoriaus veikimo principas (Darco, 2020) Fig. 1.6. Operation principle of the adjustable direction deflector (Darco, 2020) 
Vienas didžiausių tokių įrenginių privalumų - apsaugoma nuo atgalinio ištraukiamo oro srauto tekèjimo. Pučiant vejjo srautui į ịrengini, jo aerodinaminè konstrukcija pasuka deflektoriaus gaubtą kryptimi, kuria sudaroma kliūtis vejjo srauto patekimui i įsiurbimo kanalą. Tuo tarpu vejjo srautas aptekẻdamas deflektorių už jo sukuria žemo slègio zoną ir dèl to įvyksta oro srauto pasiurbimas iš ištraukimo kanalo.

Kitas vejo energiją naudojantis vėdinimo įrenginys - Japonijoje sukurtas įrenginys, pavadinimu „Wing Jetter“ (HASEC, 2007). Jo konstrukcija paremta aviacijoje taikomais sprendimais, todèl tam tikros įrenginio detalès primena sparnus (1.7 pav. a). Tokios konstrukcijos tikslas - apatineje sparno dalyje orui suteikti pagreičio bei tokiu būdu sukurti neigiamą slègị vẻdinimo sistemos kanale. İrenginio viršuje sumontuota mentè, kuri skirta jo orientavimui pagal vejjo kryptị.

Vèjo srautui pasiekus įrengini, jis atsiskiria ị dvi dalis. Viršutinejje dalyje susidaro pasipriešinimo jèga, todèl šioje dalyje veikia teigiamas slègis. Tuo tarpu apatinèje dalyje susidaro keliamoji jèga ir veikia neigiamas slègis. Kadangi apatinè dalis sujungta su védinimo sistemos kanalu, sukurtas neigiamas slègis inicijuoja oro ištraukimą. Tokie ịrenginiai pasižymi labai mažu triukšmo lygiu ir nesukuria pastato konstrukcijų vibracijų.

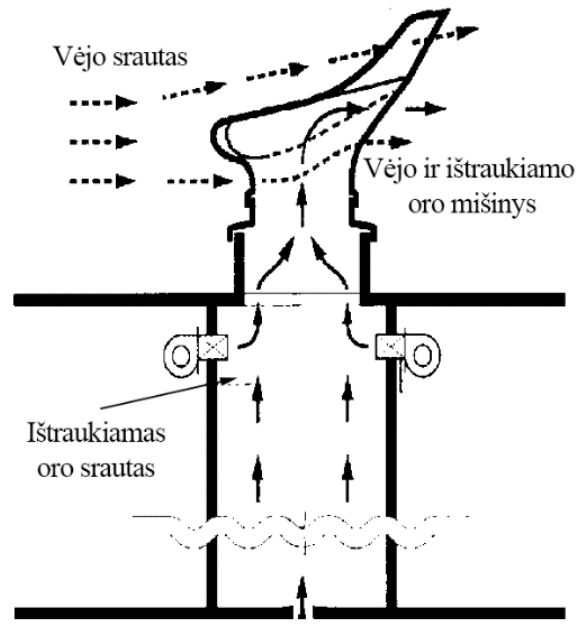

a)

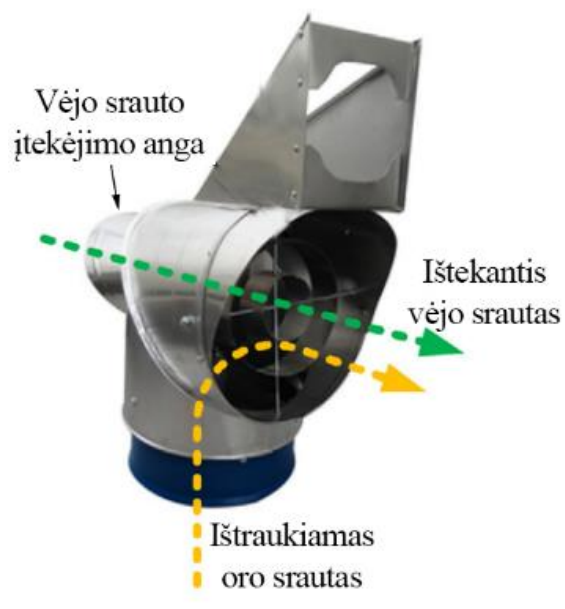

b)

1.7 pav. ,Wing Jetter“ ir Venturi tipo védinimo sistemų veikimo principų palyginimas:

a) „Wing Jetter“ (Khan, Su, \& Riffat, 2008); b) Venturi (Sik et al., 2017)

Fig. 1.7. Comparison of the operation principle of Wing Jetter and Venturi-type ventilation systems: a) „Wing Jetter“ (Khan, Su, \& Riffat, 2008); b) Venturi (Sik et al., 2017) 
Panašiu veikimo principu pasižymi ir Venturi tipo vėdinimo įrenginys (1.7 pav. b). Pučiant vejjo srautui ị ịrenginio įtekejjimo angą, susidaro ežekcijos reiškinys ir tokiu būdu pasiurbiamas oro srautas iš ištraukimo angos (Han et al., 2018). Kaip ir „Wing jetter“ atveju, veikimo metu susidarius temperatūru skirtumui tarp patalpos vidaus ir išorès, kartu veikia ir gravitacijos jègos, kurios padidina ištraukiamą oro srautą.

\subsubsection{Aktyvios natūralaus vèdinimo technologijos}

Aktyvioms vejjo varomo vėdinimo technologijoms priskiriami sprendimai, kurie veikiami vejjo srauto ar papildomo energijos šaltinio, sukdamiesi, arba kitaip judėdami, atlieka mechaninị darbą (J. Lien, 2002). Mechaninio darbo metu, tokių ịrenginiu veikimas primena ịprastas elektra varomas mechanines védinimo sistemas, tačiau tam naudojama tik atsinaujinanti vejjo arba saulès energija. Vienas dažniausiai sutinkamų aktyvių natūralaus vėdinimo technologinių įrenginių stoginiai turbininiai ventiliatoriai. Šiais įrenginiais atliekamas aktyvus natūralus vėdinimas tiesiogiai priklauso nuo pučiamo vejjo srauto.

Tarp šių įrenginių egzistuota hibridiniai turbininiai ventiliatoriai, su papildomais energijos šaltiniais. Be to, prie aktyvių védinimo technologijų gali būti priskiriamos vejjo gaudyklès, kuriose ịrengti saulès elementais varomi ventiliatoriai. Dažnu atveju aktyviose technologijose naudojami papildomi energijos šaltiniai, siekiant padidinti natūralaus vėdinimo funkcionalumą.

\subsection{Stoginių turbininių ventiliatoriụ tyrimų apžvalga}

Tarp aktyvių vejjo energiją naudojančių vẻdinimo technologijų plačiai paplitę stoginiai turbininiai ventiliatoriai (STV). Šio tipo įrenginiai pasižymi nesudètingu įrengimu ir jų veikimui nèra svarbi vejjo kryptis. Tokių ịrenginių konstrukcijos pagrindą sudaro rotorius, kuris veikia kaip turbina bei ortakis su įmontuota sukimosi ašimi. Vejjo srautui pučiant ị STV, pradeda suktis įrenginio rotorius ir taip panaudota vèjo energija leidžia padidinti pastato vėdinimo intensyvumą.

Vèjo varomi STV dažnai kombinuojami kartu su natūralia vėdinimo sistema sandèliuose, cechuose, pramoniniuose bei gyvenamuosiuose pastatuose. Tokiu būdu, padidinamas ištraukiamas oro srautas, kai sudètinga užtikrinti reikiamą vėdinimo angų kiekį. Dale ir Ackerman atlikta galimybių studija parodé, kad pastatą su įprasta natūralia vėdinimo sistema papildžius STV, oro apykaitą pastate galima padidinti apie $15 \%$ (Dale \& Ackerman, 1993). Vertinant ịvairias vejjo energiją naudojančių vėdinimo sistemų technologijas nustatyta, kad STV yra geriausias pasirinkimas ịvertinus jų dydį, kainą bei vẻdinimo veiksmingumą. Nors šių įrenginių projektavimas atrodo paprastas, oro srautų procesai turbininiame 
ventiliatoriuje yra sudètingi, todèl tam plačiai taikomi eksperimentiniai tyrimai (S. T. J. Lien \& Ahmed, 2010).

Rinkoje egzistuoja hibridiniai tokio tipo ịrenginiai. Šiuo atveju dažniausiai pasitaiko STV su papildomai įmontuotu oro ištraukimo ventiliatoriumi. Iprastai, tokie ịrenginiai kompleksiškai veikia su saulès elementais. Generuojama elektros energija gali būti naudojama papildomame oro ištraukimo ventiliatoriuje, kartu veikiant su vejo varomu STV. Taip pat, saulès elementų generuojama elektros energija gali būti kaupiama akumuliatoriuose (1.8 pav.). Sukaupta energija naudojama papildomam oro ištraukimo ventiliatoriui, kai vėjo energijos neužtenka palaikyti reikiamam ištraukiamajam oro srautui. Lai atliko tyrimus su $500 \mathrm{~mm}$ rotoriaus skersmens turbininiu ventiliatoriumi, kuriame buvo įmontuotas $400 \mathrm{~mm}$ skersmens saulès elementų energija varomas vidinis ventiliatorius (Lai, 2006).

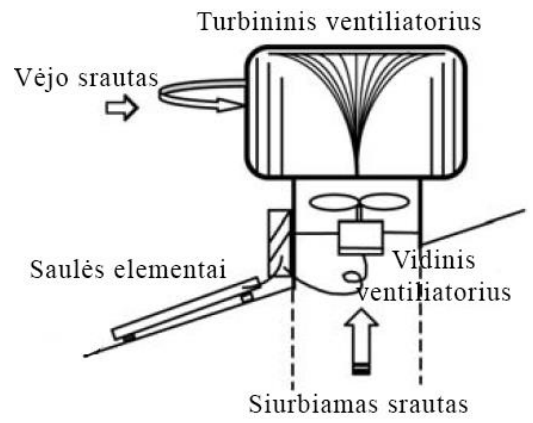

1.8 pav. Hibridinio turbininio ventiliatoriaus prototipo schema (Lai, 2006)

Fig. 1.8. Scheme of a prototype of the hybrid rooftop turbine ventilator (Lai, 2006)

Eksperimentų metu nustatyta, jog vejjo greičiui neviršijant $5 \mathrm{~m} / \mathrm{s}$, tokios konfigūracijos įrenginys pastebimai padidina vẻdinimo srautą. Tačiau esant dideliam vejjo greičiui, tokia konstrukcija blogina védinimo efektyvumą, lyginant su itprastos konstrukcijos STV.

Shun ir Ahmed taip pat sukūre hibridinị turbininio ventiliatoriaus su saulès elementais prototipą, tačiau jų tyrimo tikslas buvo maksimaliai padidinti ịrenginiu siurbiamą oro srautą (Shun \& Ahmed, 2008). Šiuo atveju buvo pasirinkta saulès elementais varoma ventiliatoriu ịrengti virš turbininio ventiliatoriaus rotoriaus. Išvadose minima, kad toks įrenginys padidina siurbiamą oro srautą, net ir esant silpnai saulès spinduliuotei. Lyginant su ịprastu turbininiu ventiliatoriumi, didžiausias tokio hibridinio ịrenginio privalumas pasiekiamas esant mažam vėjo greičiui ir didelei saulès spinduliuotei. Panašius tyrimus su hibridiniai turbininiais ventiliatoriais atliko Ismail ir Rahman (M. Ismail \& Abdul Rahman, 2010). 
Shinde et al. STV nagrinèjo kaip vėdinimo ịrenginị ir vejjo jëgainę (Shinde et al., 2016). Autoriai teigia, kad tokio įrenginio veiksmingumas priklauso nuo natūralios traukos ir rotoriaus sūkių. Sumažinus vẻdinimo intensyvumą, ịrenginị galima naudoti kaip elektros generatorių. Tyrimo metu buvo naudojamas $300 \mathrm{~mm}$ skersmens STV, kuris pasiekus 300 apsisukimų per minutę sukimosi dažnį, generavo $10 \mathrm{~V}$ įtampą ir 0,06 A srovès stiprị.

Apžvelgiant mokslinę literatūrą pastebima, jog nagrinëjant STV, labai dažnai pasitelkiami ịvairūs kiekybiniai ir kokybiniai metodai. Kiekybiniai metodai taikomi laboratorijose, atliekant eksperimentinius tyrimus vejo tuneliuose, arba atliekami bandymai realiomis sąlygomis. Matyti, jog pastarieji tyrimai sudaro didžiają dali visų atliekamų tyrimų. Prie kiekybinių metodų taip pat galima priskirti vis labiau populiarėjančius skaičiuojamosios fluidų dinamikos tyrimus, kuriais siekiama ịvertinti turbininių ventiliatorių siurbiamo oro debitą, įrenginius veikiančias aerodinamines jègas. Kita vertus, tyrimuose pasitelkiant kokybinius metodus vizualizuojami oro srauto tekejjimo procesai, atliekamos ịžvalgos įrenginių tobulinimui (Mazran Ismail \& Abdul Rahman, 2012). Toliau esančiuose poskyriuose plačiau pristatoma šiuo metu atliktų STV eksperimentinių ir skaitinių tyrimų apžvalga.

\subsubsection{Eksperimentiniai tyrimai}

West atliko eksperimentinị turbininių ventiliatorių tyrimą vèjo tunelyje ir siekè išsiaiškinti ịrenginio menčių aukščio ịtaką siurbiamam oro debitui (West, 2001). Bandymų metu buvo naudojami trys $300 \mathrm{~mm}$ skersmens STV, kurių menčių aukščiai atitinkamai siekè $170 \mathrm{~mm}, 250 \mathrm{~mm}$ bei $340 \mathrm{~mm}$. Tyrimo išvadose teigiama, kad naudojant $50 \%$ aukštesnes turbininio ventiliatoriaus mentes siurbiamas oro debitas padidèjo $13,5 \%$. Tyrejjai taip pat atkreipé dèmesį, jog toks sprendimas turi privalumą įrenginius montuojant ant šlaitinių stogų, nes įrenginio rotorius tampa labiau pasiekiamas vejjo srautui.

Lai atliko turbininių ventiliatorių tyrimus vejjo tunelyje, kuriame vejjo greitis siekè nuo $10 \mathrm{~m} / \mathrm{s}$ iki $30 \mathrm{~m} / \mathrm{s}$ (Lai, 2003). Siekdamas geriau suprasti irenginio efektyvumą lemiančius veiksnius, Lai STV tyrè trimis skirtingais etapais. Pirmojo etapo metu atliktas STV tyrimas sustabdžius rotorių, rotoriui sukantis laisva eiga bei visa tai palyginta be turbininio ventiliatoriaus (atviras oro ištraukimo ortakis). Antrojo etapo metu buvo atliktas tos pačios konstrukcijos, bet skirtingų dydžių irenginių tyrimas. Trečiojo etapo metu, tyrimas atliktas modifikavus STV, irengiant papildomas mentes rotoriaus viduje (1.9 pav.).

Atlikto tyrimo metu nustatyta, jog egzistuoja tiesioginè priklausomybė tarp STV dydžio bei ištraukiamo oro srauto. Esant didesniam įrenginiui - ištraukiamas didesnis oro srautas. Vertinant skirtumus tarp STV veikimo ịprastu režimu ir sustabdyto rotoriaus nustatyta, kad bandytų vėjo greičių diapazone, rotoriaus 
sukimasis padidina ištraukiamą oro srautą ne mažiau kaip 3 kartus. Palyginus su paprastu ištraukimo ortakiu - pastarasis sukuria ne daug didesnę trauką už sustabdytą rotorių.

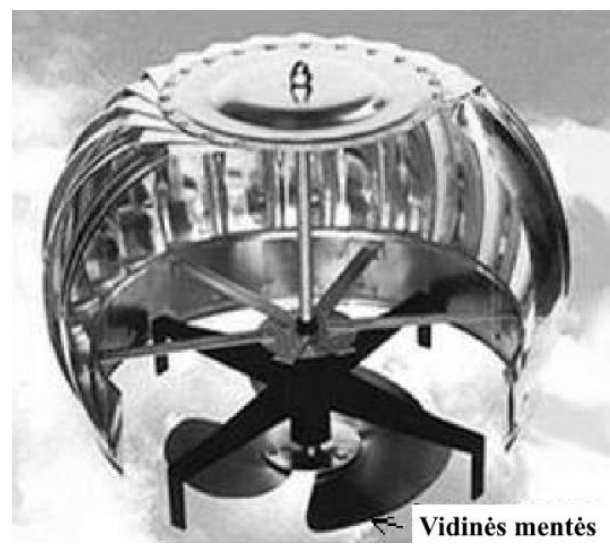

1.9 pav. Stoginis turbininis ventiliatorius su vidinėmis mentemis (Lai, 2003)

Fig. 1.9. Rooftop turbine ventilator with inner vanes (Lai, 2003)

Lai atliktas eksperimentas ịprastame STV ịrengiant vidines mentes parodè, kad toks sprendimas leidžia padidinti ištraukiamo oro srautą, tačiau šis pokytis yra minimalus. Tyrimo išvadose rašoma, kad svarbiausi kriterijai parenkant vidines mentes yra jų medžiagų savybès ir forma.

Siekiant geriau suprasti kokie oro tekejjimo procesai vyksta vejjo srautui susiduriant su STV, Lai papildomai atliko oro srautų vizualizacijos tyrimą žymètomis dujomis (1.10 pav.). Šiuo bandymu pastebèta, jog vëjo srauto dalis, kuri teka išilgai rotoriaus sukimosi krypties, atlieka rotoriaus sukimą bei už jo suformuoja aerodinamini pėdsaką (angl. wake region). Tuo tarpu vejjo srauto dalis, kuri teka prieš rotoriaus tekejjimo kryptį, stabdo įrenginio veikimą bei sudaro sąlygas oro srauto atitrūkimui. Vertindamas oro srauto tekèjimą rotoriuje, Lai teigia, kad oro siurbimo metu oro srautas yra susukamas trimis kryptimis.

Remiantis šiuo tyrimu teigiama, jog tokiame vertikalios sukimosi ašies ịrenginyje didesnis efektyvumas pasiekiamas esant mažesniam vejjo greičiui. Mokslininkų teigimu pučiant stipriam vẻjui, didelè dalis oro srauto atitrūksta nuo menčių, todèl ị tai turètų būti atkreiptas dèmesys optimizuojant ịrenginio veikimą plačiame oro greičių diapazone. 


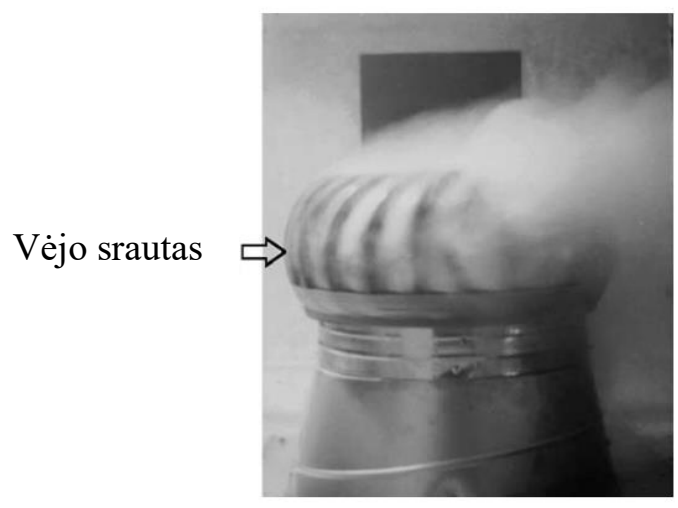

1.10 pav. Stoginis turbininis ventiliatorius veikiamas vejo srauto (Lai, 2003)

Fig. 1.10. Rooftop turbine ventilator exposed to wind flow (Lai, 2003)

Revel ir Huynh tyre skirtingų STV ir atviro oro ištraukimo kanalo skersmenų poveikị oro siurbimo debitui (Revel \& Huynh, 2007). Eksperimentinių bandymų metu nustatyta, jog STV su $300 \mathrm{~mm}$ skersmens oro siurbimo kanalu siurbia didesnį debitą nei su $250 \mathrm{~mm}$ skersmens kanalu. Kita vertus, šio tyrimo metu nustatyta, jog atviras oro ištraukimo kanalas siurbe didesnị debitą nei šiame tyrime pasirinkti turbininiai ventiliatoriai. Autoriai teigia, kad atviras oro ištraukimo kanalas turètų būti taikomas kaip atskaita atliekant turbininių ventiliatorių tobulinimą.

Kito eksperimentinio tyrimo autoriai nagrinèjo skirtingų konstrukcijų STV charakteristikas (Khan, Su, Riffat, et al., 2008). Tyrimo autorių bandymų stendas sukonstruotas remiantis Australijos/Naujosios Zelandijos standartu (AS/NZS 4740:2000, 2000). Tiriamieji turbininiai ventiliatoriai buvo įrengti patalpos modelio viršuje, o vėjo srautas reguliuojamas kintamų apsisukimų ventiliatoriumi. Už ventiliatoriaus numatytas metalinis tinklelis, kurio paskirtis užtikrinti išlygintą vèjo srautą prieš analizuojamajį STV (1.11 pav.). Vèjo greičio matavimams šiame stende naudojami trikrypčiai termoanemometrai, o bandymų metu vejjo greitis apskaičiuojamas pagal šių matavimų vidurkị. Slègio skirtumo matavimams mokslininkai naudojo „Furness Controls FCO318“ jutiklius, o STV sukimosi dažniui - optinị tachometrą.

Bandymų stendo veikimas vyksta tokiu būdu: ijungus elektrinị ventiliatorių sukuriamas dirbtinis vejjo srautas, dèl kurio prasideda STV sukimasis. Sukdamasis STV pastato modelyje ištraukia orą, todèl jo viduje sukuria neigiamą slègi. Siekiant tiksliai nustatyti šio ịrenginio ištraukiamą oro srautą atliekamas slėgių pastato viduje ir išoreje sulyginimas, todèl slègių kompensavimui naudojamas papildomas ventiliatorius. Pastaruoju ịrenginiu pučiamas oras visų pirma patenka 
ị balansavimo kamerą, kuri būtina oro srauto išlyginimui, prieš jam pratekant ị oro debito matavimo prietaisą. Šiuo atveju oro srautas matuojamas pagal slègių skirtumą tarp skirtingų matavimo prietaiso pusių.

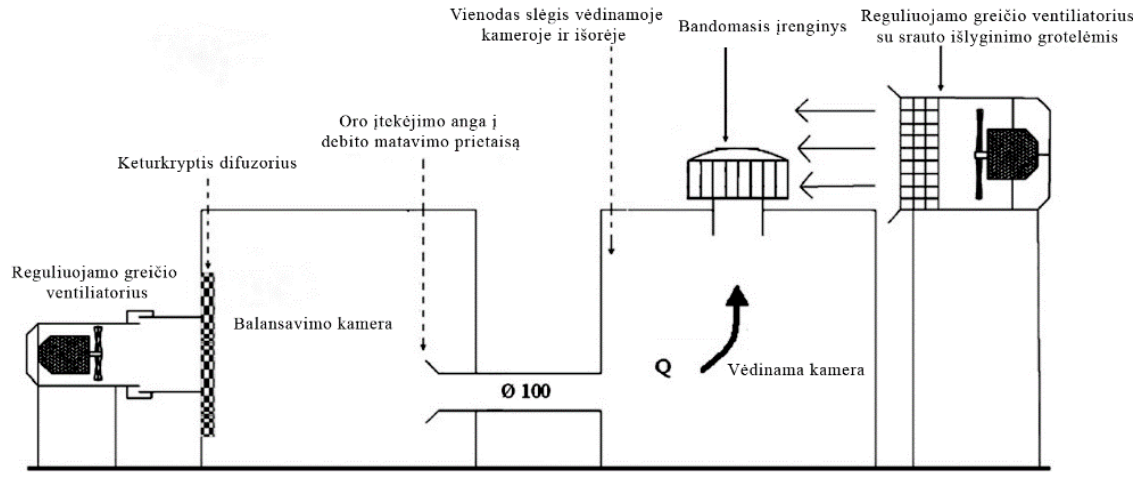

1.11 pav. Khan et al. tyrimų metu naudoto eksperimentinio stendo principinè schema (Khan, Su, Riffat, et al., 2008)

Fig. 1.11. Principal scheme of Khan et al. experimental stand setup (Khan, Su, Riffat, et al., 2008)

Tyrimu metu stende buvo bandomi keturi skirtingos konstrukcijos ir skersmenų STV: $300 \mathrm{~mm}$ skersmens STV su vertikalios ašies kryptimi tiesiomis mentėmis, $300 \mathrm{~mm}$ skersmens STV su vertikalios ašies kryptimi lenktomis mentėmis bei du $250 \mathrm{~mm}$ skersmens STV pagaminti iš polikarbonato. Vienas iš pastarujų dviejų - skaidrus, praleidžiantis saulès spindulius ir tinkamas naudoti apšvietimui dienos metu.

Tarpusavyje palyginus STV su tiesiomis ir lenktomis mentemis nustatyta, kad STV su lenktomis mentemis pasiekia apie $25 \%$ didesnị siurbiamo oro srautą. Pasak autorių esminiai faktoriai lemiančius šių ịrenginių efektyvumą yra STV skersmuo, menčių aukštis bei jų konstrukcija.

Publikacijos autoriai papildomai pateikia eksperimentiškai nustatytą ištraukiamo oro srauto priklausomybę nuo sukimosi dažnio ir šią priklausomybę palygina su išcentrinių ventiliatorių teorijoje taikomais skaičiavimais. Tyrime teigiama, jog teorinių skaičiavimų ir eksperimentinio tyrimo rezultatų skirtumas neviršija 1,5\%. Kartu su ịrenginių charakteristikų tarpusavio palyginimu, šiame straipsnyje taip pat pateikiamas palyginimas su elektriniu ventiliatoriumi bei kitais natūralaus védinimo technologiniais sprendimais.

Bay ir Phuong nagrinejjamo tyrimo metu buvo siekiama sukurti sąlygas, kuriomis būtų galima imituoti pastatą su jo viršuje ịrengtu STV arba ịprastu atviru oro ištraukimo kanalu (Bay \& Phuong, 2012). Eksperimentinis tyrimų stendas 
buvo sukonstruotas taip, kad oro srautas apipūstų tik bandinị (1.12 pav.). Siekiant modeli padaryti realesniu, jo viduje buvo įrengti papildomi šilumos šaltiniai. Toks būdas leido sukurti sąlygas, kuriomis imituojamas viryklių, kompiuterių ar kitų šilumos šaltinių poveikis šiuolaikiniuose pastatuose.

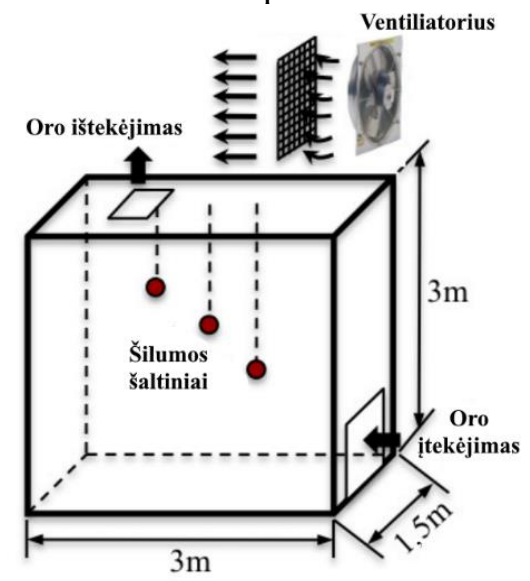

1.12 pav. Eksperimentinio stendo schema su ịrengtais šilumos šaltiniais (Bay \& Phuong, 2012)

Fig. 1.12. Experimental stand setup with installed heat sources (Bay \& Phuong, 2012)

Imituojant vedinamą pastatą, modelio konstrukcine medžiaga buvo pasirinktas medžio plokščių karkasas, vienos iš sienų apačioje padaryta anga oro ittekejjimui, o oro ištekejjimo anga palikta modelio viršuje. Oro srauto sudarymui bandymų metu naudotas elektrinis ventiliatorius. Siekiant išlyginti oro srautą prieš apipučiamus védinimo ịrenginius, eksperimentiniame tyrimų stende numatytos metalinès grotelès. Šiuo atveju vejjo srauto greitis reguliuojamas keičiant ventiliatoriaus apsisukimų skaičių arba keičiant grotelių kiekị. Tokia eksperimentinio stendo konstrukcija bandymuose leido sukurti iki 3,6 m/s vejjo greitị. Tuo tarpu ịrenginio viduje ịrengti šilumos šaltiniai sukurdavo $3 \mathrm{~kW}$ šilumos srautą, o temperatūros viduje ir išoreje skirtumas siekdavo iki $15^{\circ} \mathrm{C}$.

Vienas pagrindinių šio tyrimo metu siekiamų nustatyti rodiklių - iš pastato modelio ištraukiamo oro greitis. Autorių teigimu, oro ištraukimo greitis priklauso nuo dviejų dedamujų: vejo greičio ir dèl temperatūrų skirtumo susidarančio oro judejjimo greičio. Siekiant geriau suprasti minètojo rodiklio kitimo priklausomybę, autoriai rezultatų interpretavimui taiko bedimensinius dydžius. Bedimensinis dydis ịvertinantis vejjo ir šilumos poveiki ištraukimo greičiui apskaičiuojamas pagal šią lygtị: 


$$
v^{*}=\frac{v_{e}}{\left(u+v_{b}\right)},
$$

čia: $v^{*}$ - bedimensinis greitis; $v_{e}$ - oro ištraukimo greitis vėdinimo kanale, $\mathrm{m} / \mathrm{s}$; $u$ - vèjo srauto greitis, $\mathrm{m} / \mathrm{s} ; v_{b}$ - oro srauto greitis susidarantis dèl temperatūru skirtumo tarp aplinkos ir modelio viduje esančio oro, $\mathrm{m} / \mathrm{s}$. Šis dydis teoriškai apskaičiuojamas pagal lygtị:

$$
v_{b}=\sqrt{\frac{\Delta T g h}{T}},
$$

čia: $h$ - įtekejjimo ir ištekejimo angų aukščių skirtumas, m; $T, \Delta T$ - aplinkos oro temperatūra ir ịtekančio ị modeli ir ištekančio iš modelio oro srautų temperatūrų skirtumas, $\mathrm{K}$.

Tyrimų metu nustatyta, kad dominuojant gravitacijos jẻgoms, didžiausia ištraukiamo oro trauka susidaro iprastame atvirame ortakyje. Kita vertus, dominuojant vejjo sukuriamoms traukos jègoms - geresni rezultatai pasiekiami turbininiais ventiliatoriais.

Rashid atliko STV tyrimus Australijos New South Wales universiteto Aerodinamikos laboratorijoje, kurioje įrenginys buvo bandomas $5-25 \mathrm{~m} / \mathrm{s}$ vejjo greičių diapazone, o Reinoldso skaičius atitinkamai siekè $1,1 \cdot 10^{5}-5,5 \cdot 10^{5}$ (Rashid \& Ahmed, 2003). Šis tyrimas išsiskyrè iš kitu tuo, jog buvo matuojamos turbininius ventiliatorius veikiančios aerodinaminès jègos $x, y, z$ ašių kryptimis. Norėdami nustatyti turbininị ventiliatorių veikiančias jègas mokslininkai naudojo daugiakryptị jègos matavimo prietaisą ,ATI Analog Force/Torque (F/T) Transducer“. Atlikdami ši mokslinị tyrimą autoriai pasirinko tokias penkias bandymų konfigūracijas:

1. Nuo turbininio ventiliatoriaus nuimamas rotorius. Tokiu būdu įrenginys tapo panašus į atvirą vėdinimo kanalą.

2. Rotorius uždètas atgal, tačiau sudarant vèjo srautą, STV neleidžiama suktis, užblokuojant jo sukimosi ašį.

3. Rotoriui neleidžiama suktis bei užsandarinamos mentès.

4. STV mentès atidengiamos ir vejjo sraute įrenginys veikia ịprastu režimu.

5. STV leidžiama suktis oro sraute, bet vèl uždengiamos mentès.

Matavimo duomenų analizei autoriai naudoja aerodinaminès jègos koeficientus $C_{x}, C_{y}, C_{z}$. Šiuo atveju analizuojamas kiekvieno iš šių dydžių kitimas nuo Reinoldso skaičiaus. 


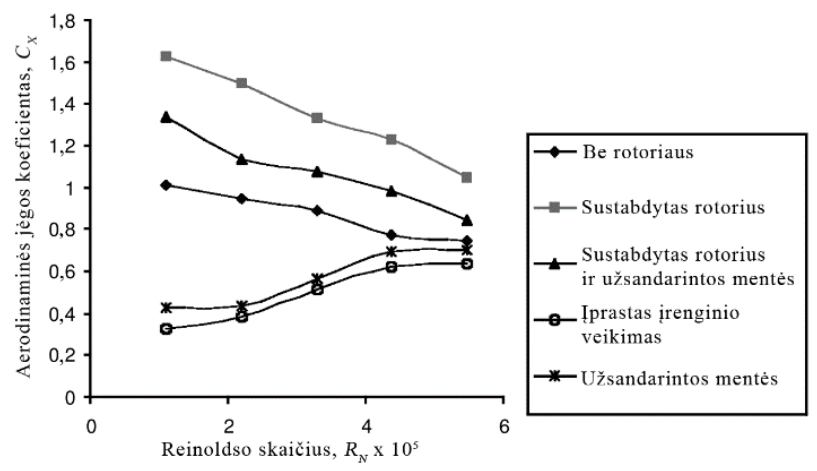

1.13 pav. Turbininį ventiliatorių veikiančios aerodinaminès jègos koeficiento $C_{x}$ kitimas nuo $R e$ skaičiaus (Rashid \& Ahmed, 2003)

Fig. 1.13. Variation of the aerodynamic force coefficient $C_{x}$ acting on the turbine ventilator versus Re number (Rashid \& Ahmed, 2003)

Eksperimentinio tyrimo rezultatai parodè, jog esant mažiems Reinoldso skaičiams (nedidelis vejjo greitis) pasiekiami maži $C_{x}$ koeficientai (1.13 pav.), o $C_{y}$ koeficientai būna dideli. Tai rodo, jog bandytasis turbininis ventiliatorius buvo efektyvesnis esant mažiems vèjo greičiams. Vertindami $C_{z}$ koeficiento kitimą autoriai pastebejjo, jog šis kyla didejant vejo greičiui, todèl esant dideliems vẻjo greičiams ịrenginys gali būti sugadintas. Mokslininkai atkreipé dèmesí, jog tobulinant šiuos įrenginius, reikètų siekti sumažinti $C_{y}$ koeficientų augimą didejjant vèjo greičiui.

\subsubsection{Skaitiniai tyrimai}

Plètojant stoginių turbininių ventiliatorių tyrimus vis dažniau pasitelkiami skaitiniai tyrimai. Tai leidžia paspartinti tyrimus sumažinant eksperimentinių tyrimų poreikị laboratorijose (Farahani et al., 2010; S. T. J. Lien \& Ahmed, 2010). Vienas iš dažniausiai pasitaikančių skaitinių tyrimų būdų - skaičiuojamoji fluidų dinamika (SFD). Kadangi STV veikimo metu susidaro oro turbulencija, uždaviniai tampa netiesiniai ir jų sprendimas tampa sudètingas. Iprastai modeliai sprendžiami pasitelkiant Navje-Stokso lygčių sistemas, ịtekejjimo ir ištekejjimo angose nurodomi pradiniai greičiai, slègiai, fluidų savybès ir kita.

Havens analizavo STV kaip išcentrinị ventiliatorių su atgal lenktomis mentėmis ir tuo pačiu veikiantị kaip vejjo jègainę (Havens, 2004). Šiuo atveju tam buvo pasirinktas skaitinis tyrimas su nesudètingu matematiniu modeliu. Tyrimo metu buvo norima nustatyti koreliaciją tarp STV sukimosi dažnio, pučiamo vèjo greičio bei siurbiamo oro srauto. Atliktoje studijoje teigiama, kad ši koreliacija 
priklauso nuo įrenginio galios ir sukimo momentų koeficientų. Autoriaus teigimu, turint šiuos koeficientus, vejo greitị ir sistemos charakteristikos kreivę, teoriškai, STV ištraukiamas oro debitas gali būti nustatomas tiksliai. Visgi, tokiam matematiniam modeliui reikalingi eksperimentiniai galios ir sukimo momento duomenys šiame tyrime nebuvo pateikti ir mokslineje literatūroje tokių tyrimų beveik nèra (Mazran Ismail \& Abdul Rahman, 2012). Galimai, tam galètų būti pritaikyti tik 2003 m. Rashid ir Ahmed atlikto eksperimento duomenys (Rashid \& Ahmed, 2003).

Farahani et al. atliko oro srautu modeliavimą naudodami „Fluent“ programinę ịrangą (Farahani et al., 2010). Taikant šią SFD modeliavimo priemonę buvo siekiama vizualizuoti oro srautus aplink STV ir jo viduje (1.14 pav.). Šiuo tyrimu taip pat buvo norima nustatyti aerodinaminiu jègų poveiki irenginio veikimo metu. Modeliavimo metu pasirinkti „ $k-\varepsilon^{“ "}$ ir Reinoldso itempimų turbulenciniai modeliai.

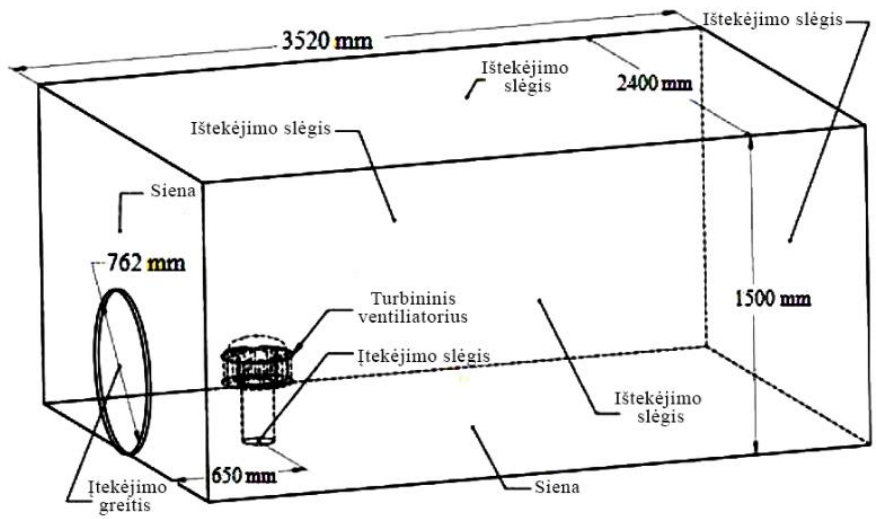

1.14 pav. Skaičiuojamosios fluidų dinamikos modelio geometrija ir kraštinès sąlygos (Farahani et al., 2010)

Fig. 1.14. Geometry and specified domains of computational fluid dynamics model (Farahani et al., 2010)

Tyrimo išvadose rašoma, $\mathrm{kad},, k-\varepsilon^{“ 6}$ turbulencinis modelis leidžia pasiekti greitesnius rezultatus, tačiau lyginant su Reinoldso įtempimų turbulenciniu modeliu yra mažiau tikslus.

Lien ir Ahmed taikydami skaičiuojamųjų fluidų dinamikos metodus siekè nustatyti oro srautų elgseną STV rotoriuje (S. T. J. Lien \& Ahmed, 2010). Atliktas skaitinis modeliavimas ir rezultatų pateikimas oro srautų vektoriais padėjo geriau suprasti vejjo ir siurbiamo oro srautų sąveiką trimatèje erdvejje (1.15 pav.). 


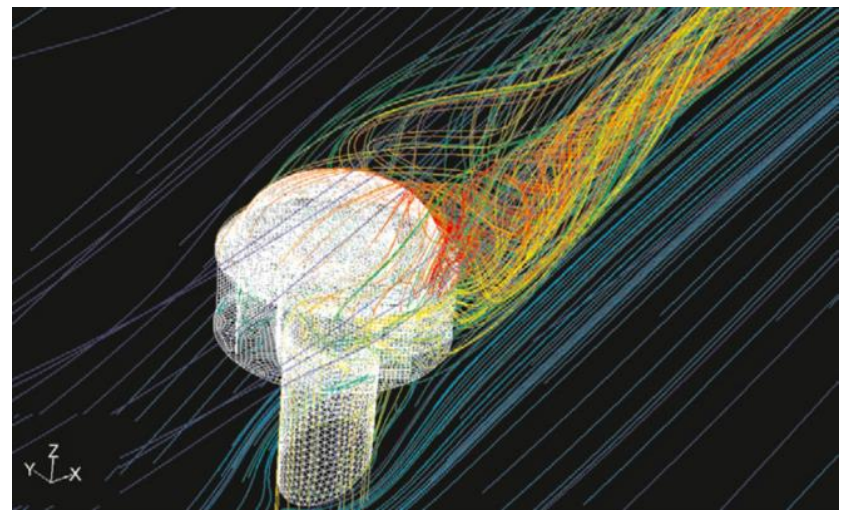

1.15 pav. Trimatė oro srautų vizualizacija (S. T. J. Lien \& Ahmed, 2010)

Fig. 1.15. Three dimensional path line of the flow (S. T. J. Lien \& Ahmed, 2010)

Analizuojant modeliavimo rezultatus pastebèta, jog ištraukiamas oro srautas bei ị rotorių patekęs vèjo srautas sūkuriais kyla aukštyn ir susimaišo su antriniu, įrenginị aptekejusiu srautu. Plètodami ši tyrimą, autoriai atiliko tyrimus keisdami turbininio ventiliatoriaus menčiu aukščius atitinkamai i $98 \mathrm{~mm}, 147 \mathrm{~mm}$ ir 196 mm. Modeliavimo rezultatais nustatyta, kad menčiu aukšti padidinus $50 \%$ ir $100 \%$ - ištraukiamo oro srautas atitinkamai padidejja $15 \%$ ir $25 \%$.

Lien ir Ahmed atlikdami eksperimentini tyrimą bei taikydami kompiuterinị modeliavimą siekè nustatyti stogo šlaito poveiki STV veiksmingumui (S. T. J. Lien \& Ahmed, 2011). Modeliavimo rezultatai parodè, kad esant mažam vejjo greičiui, stogo šlaito nuolydis turi mažą poveikị STV veikimui. Tačiau esant dideliems vejo greičiams, didejjantis stogo šlaito nuolydis mažina STV veikiančią vejjo srauto jègą ir dèl šios priežasties ženkliai sumažèja rotoriaus sukimosi dažnis. Teigiama, jog didejjant stogo šlaito nuolydžiui, padidèja vèjo srauto trintis ir dèl to sumažèja STV pasiekianti jèga.

Tarp skaitinių tyrimų verta paminèti termodinaminius modelius, kurie sudaromi ežektorių srautinių procesų tyrimams. Kaip bus vėliau pristatyta, šio darbo kontekste, ežektorius ịvardijamas kaip viena iš turbininio ventiliatoriaus sudedamujų dalių. Nevertinant taikymo srities, ežektorių matematiniai ir termodinaminiai modeliai yra gana universalūs. Daugumoje publikacijų teigiama, kad pirmasis ežektoriaus teorinis modelis buvo pristatytas Keenan and Neumann moksliniuose darbuose (Keenan, J. H., Neumann, 1942; Keenan J, Neumann E, 1950). Tai vienmačio srauto modelis, kurio pagrindą sudaro masès, linijinio momento ir energijos tvermès dèsnių lygtys.

Daugeliu atveju tokiuose modeliuose ežektoriaus oro srautai nagrinejjami kaip vienmačiai ir laike nekintantys. Taip pat, siekiant modeli padaryti paprastesniu, dažnu atveju priimamos adiabatinès sąlygos. Dėl skirtingų srautų 
trinties ir ne idealaus maišymosi sąlygų, susidaro izoentropinès sąlygos, kurios tokiuose modeliuose vertinamos taikant izoentropinius efektyvumo koeficientus (Antonio et al., 2012; Liu, J., Wang, L., Jia, L., Wang, 2018; Šarevski \& Šarevski, 2012). Iprastai, nagrinėjant ežektorius šie koeficientai taikomi atskiroms ịrenginio dalims: aktyvaus srauto tūtai, maišymo kamerai bei difuzoriui. Dalis tyrẻjų, analizuodami procesus tokiuose įrenginius pateikia $T-s$ arba $h-s$ tipo (1.16 pav.) termodinamines diagramas (He et al., 2009; Sarevski, V.N., Sarevski, 2014; Šarevski \& Šarevski, 2012).
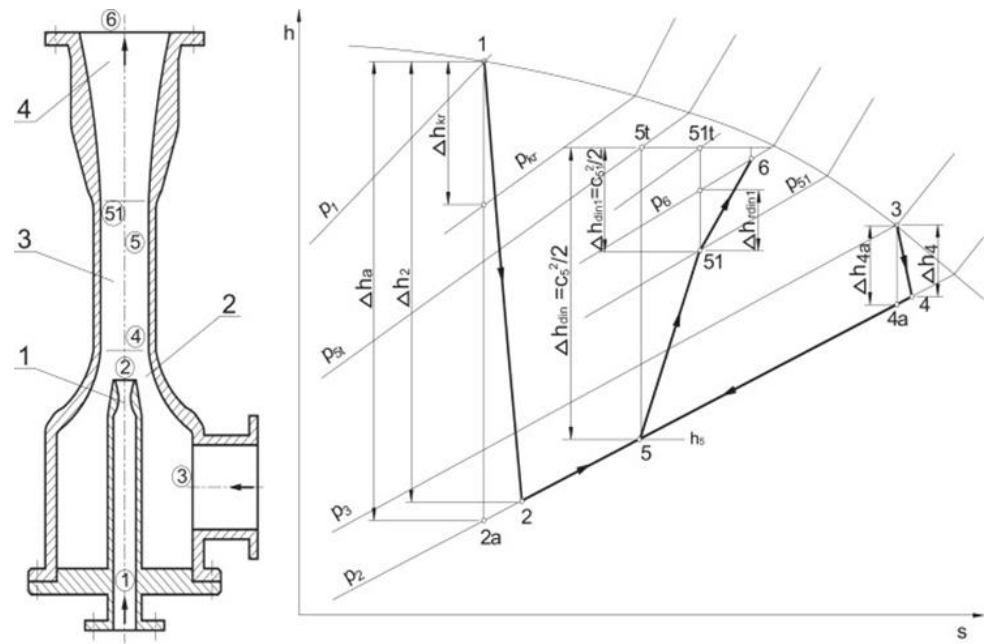

1.16 pav. Ežektoriaus termodinaminis modelis $h$-s diagramoje (Šarevski \& Šarevski, 2012)

Fig. 1.16. Thermodynamic model of ejector in $h-s$ diagram (Šarevski \& Šarevski, 2012)

Taikant tokio tipo diagramas nagrinejjami ne tik ežektoriuose vykstantys srautiniai procesai. Dažnu atveju tuo pačiu sprendžiami efektyvumo klausimai ivvairiose ežektorių pritaikymo sistemose (F. Liu, 2014).

\subsection{Stoginių turbininių ventiliatorių tyrimų suvestinė}

Apžvelgus su stoginiais turbininiais ventiliatoriaus susijusius ankstesnius mokslinius tyrimus, juos galima sugrupuoti $\mathfrak{i}$ atskiras kategorijas. Šiuo atveju moksliniai tyrimai grupuojami atsižvelgiant ị jų tipą bei autorius. Sugrupuota apžvelgtų mokslinių tyrimų suvestinè pateikiama toliau esančioje 1.1 lentelëje. 
1.1 lentelè. Stoginių turbininių ventiliatorių tyrimų suvestinè

Table 1.1. Summary of rooftop turbine ventilators research

\begin{tabular}{|c|c|}
\hline Mokslinių tyrimų tipas & Šaltiniai \\
\hline $\begin{array}{l}\text { STV ištraukiamo oro srauto kitimo } \\
\text { priklausomybès nuo vèjo greičio }\end{array}$ & $\begin{array}{l}\text { (Bay \& Phuong, 2012; Dale \& } \\
\text { Ackerman, 1993; Khan, Su, Riffat, et al., } \\
\text { 2008; Lai, 2003; Ravel, 1998; West, } \\
\text { 2001) }\end{array}$ \\
\hline $\begin{array}{l}\text { Ištraukiamo oro srauto kitimo } \\
\text { priklausomybė nuo vėjo krypties }\end{array}$ & (Dale \& Ackerman, 1993) \\
\hline Skirtingo dydžio STV charakteristikos & $\begin{array}{l}\text { (Khan, Su, Riffat, et al., 2008; Lai, 2003; } \\
\text { Revel \& Huynh, 2007; West, 2001) }\end{array}$ \\
\hline $\begin{array}{l}\text { STV oro ịtekèjimo angos skerspjūvio } \\
\text { ploto įtaka }\end{array}$ & (Revel \& Huynh, 2007) \\
\hline STV menčių aukščio įtaka & (West, 2001) \\
\hline $\begin{array}{l}\text { STV su papildomu elektriniu } \\
\text { ventiliatoriumi }\end{array}$ & $\begin{array}{l}\text { (M. Ismail \& Abdul Rahman, 2010; Lai, } \\
\text { 2006; Shun \& Ahmed, 2008) }\end{array}$ \\
\hline $\begin{array}{l}\text { STV su papildomu vidiniu } \\
\text { ventiliatoriumi }\end{array}$ & (Lai, 2003) \\
\hline STV su skirtingomis mentemis & (Khan, Su, Riffat, et al., 2008) \\
\hline Stogo nuolydžio įtaka STV veikimui & (S. T. J. Lien \& Ahmed, 2011) \\
\hline $\begin{array}{l}\text { Modifikuotas STV galintis gaminti } \\
\text { elektrą }\end{array}$ & (Shinde et al., 2016) \\
\hline STV veikiančios aerodinaminès jègos & $\begin{array}{l}\text { (Farahani et al., 2010; Rashid \& Ahmed, } \\
\text { 2003) }\end{array}$ \\
\hline $\begin{array}{l}\text { Skaitinių tyrimų taikymas apskaičiuojant } \\
\text { STV ištraukiamą oro srautą }\end{array}$ & $\begin{array}{l}\text { (Farahani et al., 2010; Havens, 2004; S. } \\
\text { T. J. Lien \& Ahmed, 2010, 2011) }\end{array}$ \\
\hline $\begin{array}{l}\text { SFD metodo taikymas su skirtingais } \\
\text { turbulencijos modeliais }\end{array}$ & (Farahani et al., 2010) \\
\hline
\end{tabular}

\subsection{Pirmojo skyriaus išvados ir disertacijos uždavinių formulavimas}

Apžvelgus vèjo energiją naudojančias natūralaus vėdinimo sistemas bei STV mokslinius tyrimus paaiškejjo: 
1. Dažnais atvejais, tiriant vejjo energiją naudojančius stoginius turbininius ventiliatorius, eksperimentiškai nustatomos ištraukiamo oro charakteristikos, tačiau trūksta tyrimų, kuriuose būtų nagrinèjama oro srautų sąveika ir energijos transformavimo procesai įrenginio veikimo metu.

2. Trūksta tyrimų, kuriuose būtų eksperimentiškai nustatytos turbininių ventiliatorių aerodinaminès, mechaninès charakteristikos, analizuojamas ịrenginių efektyvumas ir funkcionalumas hibridinejje vèdinimo sistemoje.

3. Dideleje dalyje tyrimų turbininiai ventiliatoriai analizuojami taikant skaitinius metodus, tačiau tokių įrenginių veikimas nèra aprašytas teoriniais modeliais.

4. Nepakankamai vertinamas turbininių ventiliatorių vejjo energijos akumuliavimo ir funkcionalumo padidinimo potencialas hibridinèse vèdinimo sistemose.

Apžvelgus tyrimus nustatyta, kad tikslinga atlikti eksperimentinius tyrimus, kuriais galima parengti turbininio ventiliatoriaus oro srautų sąveikos termodinaminị modelị bei ịvertinti šio ịrenginio vejo energijos akumuliavimo potencialą. Tam reikia spręsti šiuos uždavinius:

1. Parengti ir ịvykdyti vèjo energiją naudojančių STV eksperimentinių tyrimų programą, kuria struktūrizuojami hibridinès vėdinimo sistemos veikimo režimai bei nustatomos STV mechaninès ir aerodinaminès charakteristikos.

2. Kiekybiškai ir kokybiškai palyginti skirtingų STV eksperimentines sukimo momentų, dažnių, galių ir oro srautų charakteristikas, nustatyti jų empirines lygtis ir palyginti su teorinemis lygtimis.

3. Atsižvelgiant ì eksperimentinių tyrimų rezultatus, pasiūlyti STV konstrukciją ir tekejjimo procesus jame atspindinčią struktūrinio suskaidymo koncepciją, kuri būtų palanki procesų termodinaminio modelio formavimui.

4. Parengti pasirinktu STV komponentų integruojantị veikimo termodinaminị modelị ir ji pagrịstai susieti su eksperimentinių tyrimų rezultatais.

5. Ivvertinti galimybes padidinti vejo energijos panaudojimo efektyvumą STV, esant stochastiniam vejjo kitimui metų cikle. 



\section{Turbininių ventiliatorių mechaniniai ir aerodinaminiai tyrimai}

Šiame skyriuje pateikta vejjo energiją naudojančių turbininių ventiliatorių eksperimentinių tyrimų programa, metodika bei tyrimų rezultatai. Šių tyrimų metu kiekybiškai palyginamos skirtingų vejjo energija naudojančių ventiliatorių ištraukiamo oro charakteristikos, esant skirtingoms vejjo greičio ir aplinkos statinio slègio sąlygoms. Be to, analizuojant turbininius ventiliatorius, atliekami generuojamos galios bandymai bei tokių ịrenginių aerodinaminių charakteristikų tyrimai. Eksperimentiniai tyrimai atlikti Vilniaus Gedimino technikos universiteto ir Portugalijos Nacionalinėje civilinès inžinerijos laboratorijose, atsižvelgiant $\mathfrak{i}$ tarptautinius bandymo standartus ir mokslinejje literatūroje randamus metodus.

Skyriaus tematika paskelbtos keturios publikacijos (Rimdžius et al., 2018; Rimdžius \& Bielskus, 2018; Streckienè et al., 2018; Sketerskis et al., 2018).

\subsection{Eksperimentinių tyrimų programa ir bandomi irenginiai}

Ankstesnių mokslinių tyrimų apžvalga rodo, jog trūksta tyrimų apie turbininiuose ventiliatoriuose vykstančius srautinius procesus bei nèra šiuos reiškinius vienijančio teorinio aprašo. STV veikimo metu ịrenginys yra veikiamas vẻjo 
srauto, ištraukiamo oro srauto, vyksta šių srautų maišymosi procesai, sukasi ịrenginio rotorius, veikia ịvairios aerodinaminès jègos bei vyksta kiti reiškiniai. Ši kompleksinè reiškinių visuma yra sudètinga, todėl atskirų procesų poveikis negali būti aprašomas žinant tik pradines vėjo srauto ir vėdinamos patalpos sąlygas. Šiuo atveju norint parengti turbininio ventiliatoriaus termodinamini modelị, prieš tai reikalinga atskleisti atskirus STV veikiančius procesus. Šiame darbe tam pasitelkiami eksperimentiniai tyrimai, kurių metu palaipsniui eliminuojami tam tikri ipprastinio veikimo faktoriai. Siekiant atskleisti ir eksperimentiškai patikrinti ìvairialypę oro srautų sąveiką vejjo energiją naudojančiuose stoginiuose turbininiuose ventiliatoriuose - parengta speciali eksperimentinių tyrimų programa. Šios eksperimentinių tyrimų programos rezultatai toliau taikomi analizuojant atskirų srautinių procesų sąveikinius ryšius bei pagal tai formuojamas įrenginio veikimo termodinaminis modelis.

Eksperimentų metu atliekami mechaninių ir aerodinaminių charakteristikų matavimai, nustatoma skirtingų oro srautų įtaka veiksmingumui, efektyvumui ir funkcionalumui. Detaliems mechaninių, aerodinaminių ir hibridinès vėdinimo sistemos veikimo režimus imituojančiam tyrimui pasirinkti STV bandymai septyniais skirtingais veikimo režimais, o bandymo sąlygos keičiamos penkiais etapais. Siekiant atlikti kiekybinius ir kokybinius palyginimus, tyrimo metu bandomi trys skirtingi turbininiai ventiliatoriai, deflektorius ir atviras oro ištraukimo ortakis.

Pirmajam tyrimui pasirinktas bandymas naudojant tik atvirą oro ištraukimo ortaki. Šio bandymo tikslas nustatyti ištraukiamo oro srauto kitimą be STV bei šiuos rodiklius palyginti su kitais bandymais. Bandymo metu reguliuojamas vėjo greitis ir statinis slègis vėdinamoje patalpoje. Antrojo tyrimu metu ant oro ištraukimo ortakio uždedamas STV ir jis tiriamas įprastinėmis veikimo sąlygomis. Bandymo sąlygos keičiamos analogiškai pirmajam bandymui. Trečiojo bandymo tikslas - sudaryti sąlygas vėjo srauto ịsiurbimui ì vėdinamą erdvę ir nustatyti ịrenginių charakteristikas tokio veikimo režimo metu. Ketvirtojo bandymo metu bandytiems įrenginiams uždaromas oro siurbimo kanalas. Tyrimu siekiama nustatyti oro siurbimo rodikli $C_{p}$ ir ištraukiamo oro srauto poveiki ịrenginio rotoriui. Penktasis bandymas atliekamas sustabdžius STV rotorių. Tyrimo tikslas - įvertinti STV ištraukiamo srauto poveiki dèl rotoriaus sukimosi ir nustatyti maksimalų įrenginio sukuriamą sukimo momentą. Šeštuoju bandymu apkraunamas STV rotorius bei siekiama nustatyti jo generuojamą galią ir poveikị ištraukiamo oro srautui. Septintasis bandymas atliekamas STV rotorių sukant elektriniu varikliu ir nepučiant vejjo srautui. Šiuo bandymu norima nustatyti STV rotoriaus veiksmingumą, veikiant ịprasto ventiliatoriaus režimu.

Priklausomai nuo tiriamo STV veikimo režimo, bandymo sąlygos keičiamos reguliuojant vèjo srauto greitị, išjungiant vèjo srautą, uždarant oro siurbimo kanalą, reguliuojant statini slègi vėdinamoje patalpoje ar sukimo momento 
matavimo prietaisu reguliuojant rotoriaus apkrovimą.

Pasirinkta eksperimentinių tyrimų programa leidžia eliminuoti atskirus STV realaus veikimo vykstančius procesus ar komponentus. Tokiu būdu gautais rezultatais galima kiekybiškai ịvertinti atskirų procesų įtaką STV veikimui, analizuoti ịrenginių tobulinimo galimybes. 2.1 lenteleje pateikiama eksperimentinių tyrimų programos suvestinè.

2.1 lentelè. Eksperimentinių tyrimų programos suvestinè

Table 2.1. Summary of the experimental research programme

\begin{tabular}{|c|c|c|c|c|c|c|c|}
\hline \multirow[b]{2}{*}{ Bandymo sąlygos } & \multicolumn{7}{|c|}{ STV veikimo režimas } \\
\hline & $\begin{array}{l}z \\
\infty \\
0 \\
0 \\
\infty\end{array}$ & 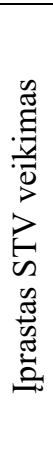 & 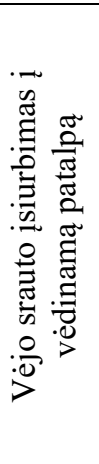 & 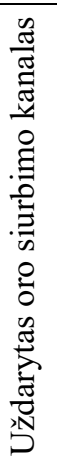 & 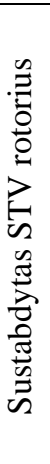 & 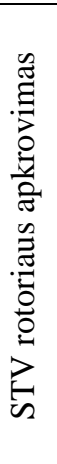 & 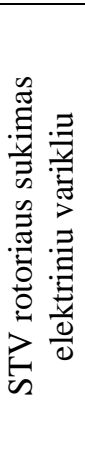 \\
\hline 1 & 2 & 3 & 4 & 5 & 6 & 7 & 8 \\
\hline Be vèjo srauto & & & & & & & + \\
\hline Vèjo srauto greičio reguliavimas & + & + & + & + & + & + & \\
\hline $\begin{array}{l}\text { Uždarytas STV oro siurbimo } \\
\text { kanalas }\end{array}$ & & & & + & & & \\
\hline $\begin{array}{l}\text { Statinio slègio reguliavimas } \\
\text { vėdinamoje patalpoje }\end{array}$ & + & + & + & & + & + & \\
\hline $\begin{array}{l}\text { STV rotoriaus apkrovos } \\
\text { reguliavimas }\end{array}$ & & & & & & + & \\
\hline \multicolumn{8}{|l|}{ Matuojami rodikliai } \\
\hline $\begin{array}{l}\text { Ištraukiamas oro srautas } \dot{Q}_{e}, \\
\mathrm{~m}^{3} / \mathrm{h}\end{array}$ & + & + & + & & + & + & + \\
\hline $\begin{array}{l}\text { STV rotoriaus sukimosi dažnis } \\
\omega, \text { RPM }\end{array}$ & & + & + & + & & + & + \\
\hline Vejo srauto greitis $u, \mathrm{~m} / \mathrm{s}$ & + & + & + & + & + & + & \\
\hline
\end{tabular}


2.1 lentelès pabaiga

\begin{tabular}{|l|c|c|c|c|c|c|c|}
\hline \multicolumn{1}{|c|}{1} & 2 & 3 & 4 & 5 & 6 & 7 & 8 \\
\hline $\begin{array}{l}\text { Statinis slègis vėdinamoje } \\
\text { patalpoje } P_{s c}, \mathrm{~Pa}\end{array}$ & + & + & + & & + & + & + \\
\hline $\begin{array}{l}\text { Statinis slègis vėjo tunelyje } P_{s w}, \\
\text { Pa }\end{array}$ & + & + & + & + & + & + & + \\
\hline $\begin{array}{l}\text { STV rotoriaus sukimo momentas } \\
\tau, \text { Nm }\end{array}$ & & & & & + & + & \\
\hline $\begin{array}{l}\text { Aerodinaminè STV traukos jèga } \\
F_{d}, \mathrm{~N}\end{array}$ & & + & & & + & & \\
\hline
\end{tabular}

Lentelès matuojamų rodiklių sekcijoje matoma, jog šių tyrimų metu, priklausomai nuo bandymo tikslo, matuojami STV ištraukiamo oro srautai, STV rotorių sukimosi dažniai ir sukimo momentai, vejo srauto greitis, statinis slègis vėdinamoje patalpoje, statinis slègis vejjo tunelyje bei STV veikianti aerodinaminè traukos jèga.

Tyrimų metu bandomi trys skirtingos konstrukcijos, tačiau vienodo veikimo principo turbininiai ventiliatoriai. Dviejų iš jų rotoriaus konstrukciją sudaro vertikalios ašies kryptimi lenktos mentès, o trečiojo įrenginio rotoriaus mentès vertikaliai tiesios. Irenginiu palyginimui papildomai buvo bandomas ir stoginis deflektorius. 2.1 paveiksle pateikiamos bandomų irenginių nuotraukos, žymėjimai ir pagrindiniai matmenys.

\begin{tabular}{|c|c|c|c|}
\hline Žymëjimas: STV1 & Žymėjimas: STV2 & Žymėjimas: STV3 & Žymejjimas: D1 \\
\hline Tipas: turbininis & Tipas: turbininis & Tipas: turbininis & Tipas: statinis \\
\hline $\begin{array}{l}\text { Matmenys: } h= \\
190 ; w=190 ; d_{i}= \\
128\end{array}$ & $\begin{array}{l}\text { Matmenys: } h= \\
275 ; w=245 ; d_{i}= \\
118\end{array}$ & $\begin{array}{l}\text { Matmenys: } h= \\
234 ; w=240 ; d_{i}= \\
150\end{array}$ & $\begin{array}{l}\text { Matmenys: } h=142 ; w= \\
255 ; d_{i}=118\end{array}$ \\
\hline
\end{tabular}

2.1 pav. Bandomų ịrenginių nuotraukos, žymèjimai ir pagrindiniai matmenys Fig. 2.1. Pictures of test devices, labels, and key dimensions

Žymèjimai 2.1 paveiksle: $h$-įrenginio aukštis, mm; $w$ - įrenginio plotis, mm; $d_{i}-$ ištraukiamo oro įtekejjimo angos skersmuo, mm. Bandymų metu, kartu su šiais 
ịrenginiais naudojami atviri oro ištraukimo ortakiai, kurių dydis parenkamas pagal bandomų įrenginių oro siurbimo angos skersmenį.

\subsection{Eksperimentinių tyrimų metodika}

Eksperimentiniu tyrimu metodikos dalyje pristatomi tyrimo metu naudoti eksperimentiniai stendai, matavimo metodai ir tyrimuose naudota matavimo įranga. Taip pat, šiame skyriuje pateikiama įrenginių charakteristikų skaičiavimo metodika ir šių tyrimų neapibrèžties vertinimas.

\subsubsection{Eksperimentinių tyrimų stendai}

Eksperimentiniai tyrimai atlikti Vilniaus Gedimino technikos universiteto laboratorijoje ir Portugalijos Nacionalinèje civilinès inžinerijos laboratorijoje. Tyrimai atlikti laboratorijų vejjo tuneliuose, o bandymų stendai ịrengti atsižvelgiant ị tarptautinius STV bandymo standartus „EN 13141-5“ (EN 131415, 2004), „AS/NZS 4740:2000“ (AS/NZS 4740:2000, 2000) bei remiamasi mokslinèse publikacijose (Khan, Su, Riffat, et al., 2008; Lai, 2003) pateiktų eksperimentinių tyrimų idèjomis.

Šiuo atveju bandymams naudoti trijų skirtingų tipų stendai. Pirmasis bandymų stendas skirtas ištraukiamo oro srautų ir ịrenginių generuojamos galios matavimui (2.2 pav.). Bandymams naudojamas modifikuotos konstrukcijos atviras vejjo tunelis su specialia, védinamą patalpą imituojančia kamera. Bandomasis STV i̇montuojamas vèjo tunelyje bei ortakiu prijungiamas prie vẻdinamą patalpą imituojančios kameros. Eksperimentų metu vẻdinamą patalpą imituojančioje kameroje reikiamas slègis palaikomas atskiru prijungtu reguliuojamos galios ventiliatoriumi.

Bandomasis turbininis ventiliatorius ortakiu prijungiamas prie oro srauto stabilizavimo kameros, kurios paskirtis imituoti védinamą patalpą ir palaikyti bandymui reikiamą statinị slègio skirtumą tarp vidaus ir išorès. Slègio matavimo taškai ịrengti oro srauto stabilizavimo kameros sienelių vidinèje pusèje bei eksperimentinio tyrimu stendo viduje, kartu su „Pitot“ vamzdeliu. Siekiant padidinti matavimo tikslumą, oro srauto stabilizavimo kameroje irrengti matavimo taškai sujungti pjezometrinio žiedo principu.

Bandymų metu, skirtingų vejjo greičių užtikrinimui naudojami reguliuojamos galios vèjo tunelio ventiliatoriai. Dèl ribotos bandymų stendo ventiliatorių galios ir reguliavimo režimų, eksperimentų metu vèjo greičiai reguliuojami trimis pakopomis: $2,7 \mathrm{~m} / \mathrm{s}, 5,6 \mathrm{~m} / \mathrm{s}$ ir $9,2 \mathrm{~m} / \mathrm{s}$. Vejjo greičio matavimams naudojamas "Pitot" vamzdelis. 

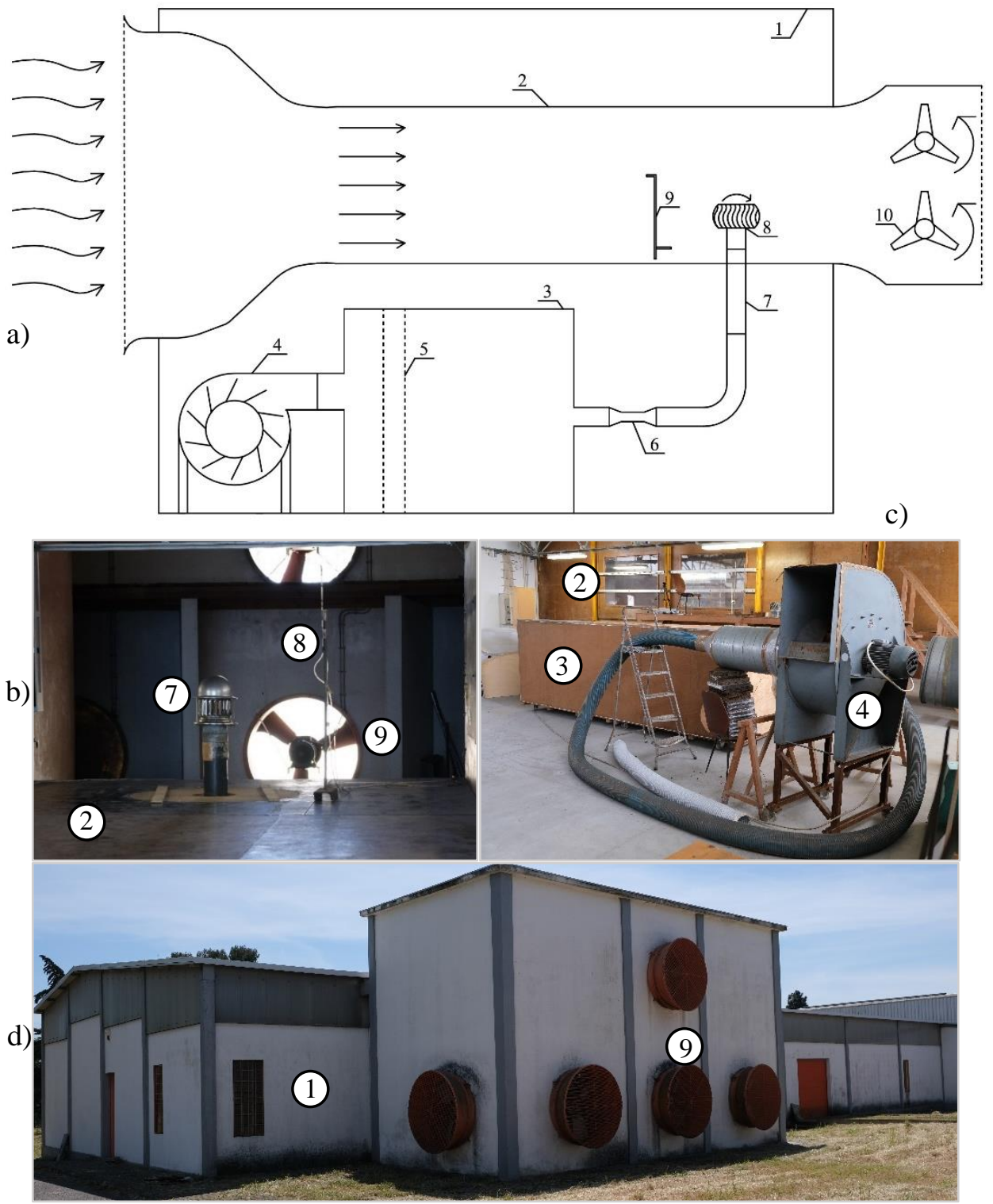

2.2 pav. Nacionalinès civilinès inžinerijos laboratorijos eksperimentinių tyrimų stendas:

a) stendo schema; b) bandomasis įrenginys vëjo tunelyje; c) bandymų stendo komponentai; d) vejjo tunelio ventiliatoriai

Fig. 2.2. Experimental stand of National Laboratory for Civil Engineering: a) stand scheme; b) test device inside a wind tunnel; c) components of experimental stand;

d) ventilators of wind tunnel 
Žymėjimai 2.2 paveiksle: 1 - bandymų laboratorijos patalpa; 2 - atviro tipo vejo tunelis; 3 - oro srauto stabilizavimo kamera; 4 - statinị slègi védinamoje patalpoje reguliuojantis ventiliatorius; 5 - oro srauto stabilizavimo tinklas; 6 ištraukiamo oro srauto matavimo prietaisas; 7 - oro ištraukimo ortakis; 8 bandomasis įrenginys; 9 - „Pitot" vamzdelis pučiamo oro srauto greičiui matuoti; 10 - vejjo tunelio ventiliatoriai.

Siurbiamam oro srautui matuoti tyrimų stende įrengta „Venturi“ tipo tūta, kuri prijungta tarp vejo tunelyje irengto ortakio ir oro srauto stabilizavimo kameros. Pastaroji kamera yra prijungta prie reguliuojamo greičio ventiliatoriaus, kurio paskirtis kompensuoti slègio nuostolius iki įtekẻjimo ị bandomo įrengimo pajungimo angą bei palaikyti reikiamą slègi vėdinamą patalpą imituojančioje kameroje. Kitas svarbus rodiklis yra STV rotoriaus sukimosi dažnis (angl. RPM). Bandymų metu, turbininių ventiliatorių sukimosi dažnio matavimai atliekami optiniu tachometru „Extech RPM33“.

Antrasis bandymų stendas ịrengtas Vilnius Tech laboratorijoje. Šio stendo konstrukciniai sprendimai panašūs ị anksčiau minètą NCIL tyrimu stendą, tačiau jame papildomai įrengtas reguliuojamo greičio elektrinis variklis, kuris skirtas turbininio ventiliatoriaus rotoriaus sukimui. Siekiant papildomu energijos šaltiniu sukurti bandomojo įrenginio sukimą, elektrinio variklio ašis metaliniu strypu sujungta su turbininio ventiliatoriaus rotoriaus viršutine dalimi. Šiuo atveju elektrinio variklio sukimosi dažnis reguliuojamas naudojant atvirojo kodo „Arduino“ valdiklị, kuriuo keičiami greičio reguliatoriaus parametrai. 2.3 paveiksle pateikiama Vilnius Tech eksperimentinio tyrimu stendo schema ir nuotraukos.

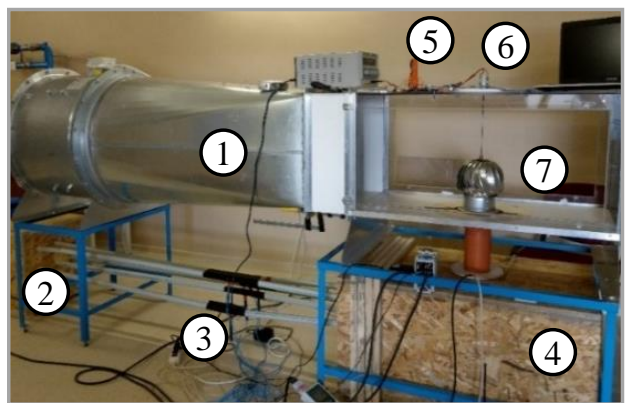

a)

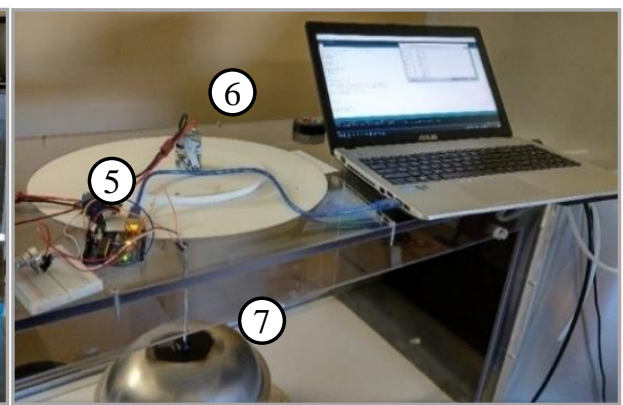

b)

2.3 pav. Vilnius Tech eksperimentinio stendo nuotraukos: a) pagrindiniai komponentai ir bandomasis įrenginys; b) greičio valdiklis ir reguliuojamos galios variklis

Fig. 2.3. Pictures of Vilnius Tech experimental stand: a) main components and test device; b) speed controller and adjustable power motor

Žymėjimai 2.3 paveiksle: 1 - Vilnius Tech laboratorijos atviro tipo vèjo tunelis; 2 - oro srauto stabilizavimo kamera; 3 - oro debito matavimo prietaisai; 
4 - statinio slègio reguliavimo kamera; 5 - „Arduino“ valdiklis ir greičio reguliatorius; 6 -reguliuojamos galios variklis; 7 - bandomasis įrenginys.

Trečiasis bandymų stendas skirtas ịrenginių aerodinaminių charakteristikų matavimui (2.4 pav.). Aerodinaminių jègų matavimai buvo atlikti specialios konstrukcijos ortodinamometru (Freitas et al., 2014), kuris buvo įrengtas po NCIL laboratorijos vejjo tuneliu. Ortodinamometras sudarytas iš metalinio lygiagretainio su dviem elastiniais mazgais apačioje ir dviem mazgais viršuje, kartu su specialiais laikikliais bandomiesiems modeliams. Bandymų metu turbininiai ventiliatoriai yra veikiami vèjo jègų, kurių aerodinaminès traukos jègos yra tiesiogiai perduodamos sujungtai viršutinei ortodinamometro profilio daliai.

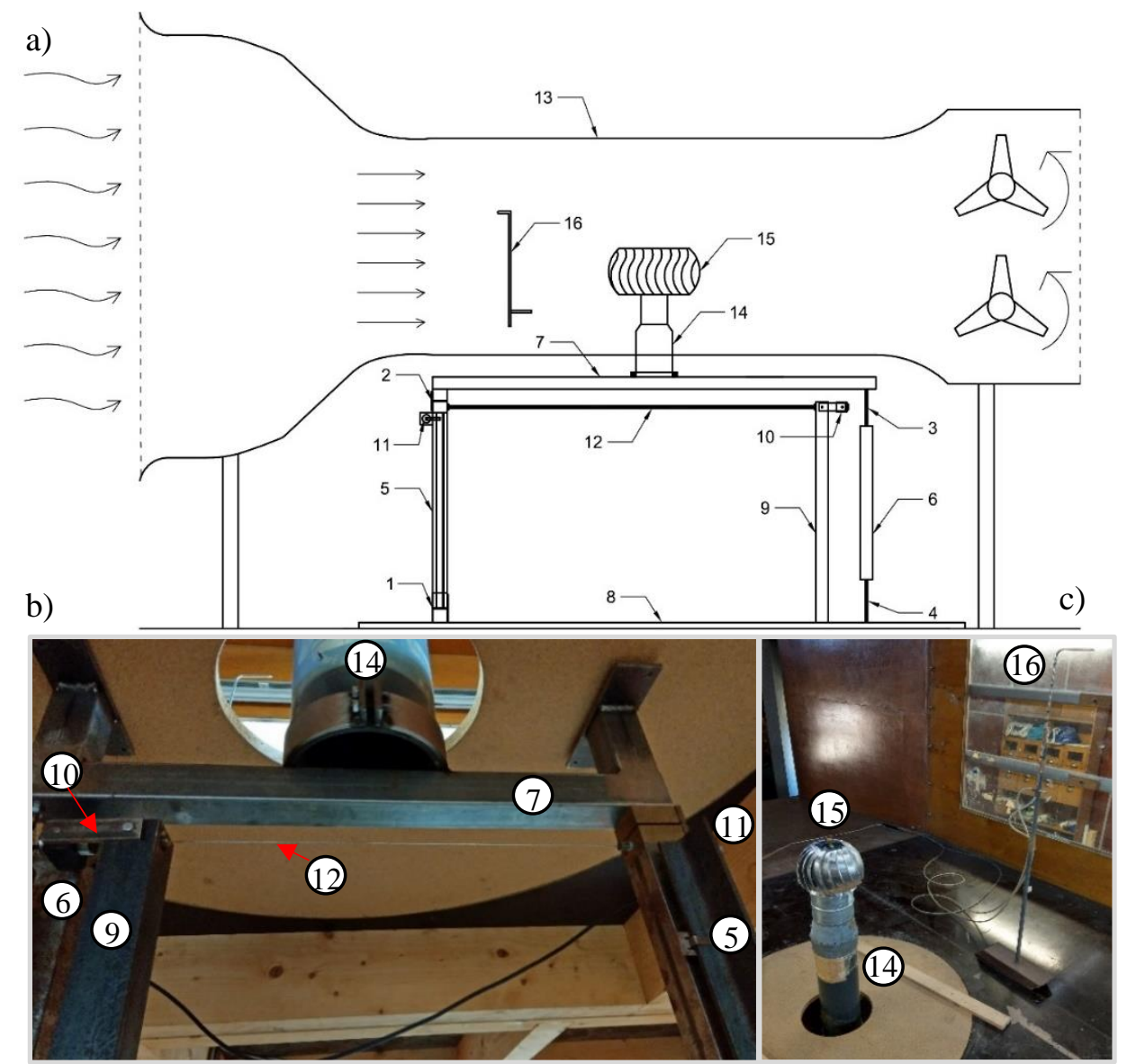

2.4 pav. Aerodinaminių charakteristikų matavimo stendas: a) stendo schema;

b) ortodinamometro nuotrauka; c) bandomojo įrenginio nuotrauka

Fig. 2.4. Aerodynamic characteristics measurement stand setup: a) stand scheme;

b) picture of orthodynamometer; c) picture of test device 
Žymèjimai 2.4 paveiksle: 1 - reguliuojamo standumo mazgas; 2 - mazgas su nedideliu kampiniu standumu veikiant sukimo jègoms apie skersinę ašịi; 3, 4 mazgai su nedideliu kampiniu standumu veikiant sukimo jègoms išilginèse ir skersinèse ašyse; 5 - pirmasis statramstis; 6 - antrasis statramstis; 7 ortodinamometro viršutinis profilis su bandinio fiksatoriumi; 8 ortodinamometro pagrindas; 9 - atraminis LVDT jutiklio profilis; 10 - išilginis LVDT jutiklis; 11 - skersinis LVDT jutiklis; 12 - „Invar“ tipo laidas; 13 - vejo tunelis; 14 - oro ištraukimo ortakis; 15 - bandomasis įrenginys; 16 - „Pitot“ vamzdelis vejjo greičio matavimui.

Tokio ortodinamometro konstrukcija leidžia kartu matuoti išilgines ir skersines aerodinaminių jègų apkrovas. Išilginès aerodinaminès jègos deformuoja lygiagretaini jo paties plokštumoje. Tuo tarpu skersinès aerodinaminès jègos visą lygiagretaini lenkia iš jo pradinès padèties. Abu šie deformaciniai poslinkiai yra proporcingi aerodinaminèms jègoms, kurios veikia turbininị ventiliatorių ir kartu montuojamą ištraukimo kanalą.

Visi lygiagretainio mazgai deformuojasi elastiškai, tačiau pagrindinis jų skirtumas yra kampinis standumas aplink tris ašis. 1 ir 2 mazgai, sutvirtinantys pagrindinę lygiagretainio kraštinę, yra pagaminti iš plieninès spyruoklès. 3 ir 4 mazgai pagaminti iš plieno lakštų ir pasižymi nedideliu kampiniu standumu veikiant sukimo jẻgoms apie skersinę ašį. Priklausomai nuo bandymų sąlygų, 4 mazgo standumas gali būti reguliuojamas.

Bandymų metu deformacijų poslinkiai yra matuojami dviem „LVDT“ jutikliais, kurių parodymai yra tiesiogiai proporcingi aerodinaminès jègoms. Šiuo atveju naudojami du „LVDT“ jutikliai „Solartron DF2.5“, kurių matavimo diapazonas siekia iki $5 \mathrm{~mm}$. Išilginès jègos matavimams skirtas „LVDT“ jutiklis irengtas ant atraminio profilio, kuris sujungtas su ortodinamometro pagrindu ir neturi jokio poveikio deformuojantis lygiagretainiui. Skersiniu jègu "LVDT“ jutiklis irengtas ant pirminio statramsčio. Ortodinamometro konstrukcinis pagrindas pagamintas iš plieno ir sustiprintas „L“ formos profiliais ir prisuktas prie betoninio grindinio.

Siekiant sumažinti temperatūrini poveikị matavimo tikslumui, „LVDT“ jutikliai naudojami kartu su „Invar“ lydinio laidais. Matavimo stendo jutikliai prijungti prie „National Instruments NI 9215“ iejeimo modulio ir nuskaitomi „Labview Signal Express” duomenu surinkimo sistema. Remiantis ankstesniais ortodinamometro tikslumo bandymais (Freitas et al., 2014), prietaiso matavimo paklaida siekia mažiau $0,7 \%$.

\subsubsection{Ištraukiamo oro srauto įvertinimas}

STV ištraukiamas oro srautas priklauso nuo vejjo greičio, įrenginio aerodinaminių charakteristikų, temperatūros skirtumo tarp vėdinamos patalpos ir atmosferos, 
montavimo vietos, angų tipo, pastato sandarumo lygio bei kitų faktorių. Dėl šios priežasties tampa sudètinga nustatyti STV ištraukiamo oro charakteristikas. Priklausomybè nuo visų šių parametrų apsunkina tokių įrenginių tyrimus, todėl STV tyrimams plačiai naudojami eksperimentiniai tyrimai. Ivertinus tai, kad šiuos faktorius galima suskirstyti i priklausančius nuo vejo greičio ir slègio - bandymu metu ịrenginiai tiriami keičiant vejjo greiti bei statinio slègio skirtumą tarp vėdinamos patalpos ir išorès.

Kadangi STV ištraukiamo oro srauto kitimas daugiausia priklauso nuo vejjo greičio ir statinio slègio sąlygų, įrenginių kiekybiniam ir kokybiniam tyrimui pasirinkta bedimensinès analizès metodika. Šiam tikslui taikoma Buckingham $\pi$ teorema, kuri paremta masès, ilgio ir laiko fizikiniais dydžiais. Šią bedimensès analizės metodiką 1932 m. savo tyrimuose pritaikẻ Savonius (Savonius, 1932). Vèlesniuose tyrimuose tai buvo pritaikyta Revel, Welsh moksliniuose darbuose (Revel \& Huynh, 2007; Welsh, 1994).

Fundamentaliai, STV ištraukiamas oro srautas priklauso nuo vèjo greičio, oro tankio, statinio slègio skirtumo tarp vėdinamos patalpos ir lauko oro, STV oro ištraukimo ortakio skersmens. Bendru atveju tokị procesą galima išreikšti funkcija $f\left(\dot{Q}_{e}, \rho, u, \Delta P_{s}, d_{i}\right)$. Ivertinus šiuos kintamuosius pagal masès, ilgio ir laiko fizikinius dydžius, remiantis Buckingham $\pi$ teorema sudaromi du bedimensiniai parametrai:

$$
\begin{aligned}
& \pi_{1}=\frac{\Delta P_{s}}{\rho u^{2}} ; \\
& \pi_{2}=\frac{\dot{Q}_{e}}{u d_{i}^{2}},
\end{aligned}
$$

čia $\pi_{1}$ - pirmasis bebedimensinis parametras, vnt.; $\pi_{2}$ - antrasis bebedimensinis parametras, vnt.; $\dot{Q}_{e}-\mathrm{STV}$ ištraukiamas oro srautas, $\mathrm{m}^{3} / \mathrm{s} ; \rho$ - oro tankis, $\mathrm{kg} / \mathrm{m}^{3}$; $u$ - vejjo greitis, $\mathrm{m} / \mathrm{s} ; \Delta P_{s}-$ vèdinamos patalpos ir lauko oro statinio slègio skirtumas, $\mathrm{Pa}$.

Remiantis šia teorema sudarytais bedimensiniais parametrais, STV gali būti lyginami pagal vienodas statinių slègių ir vejjo greičių vertes bei tuo pačiu atsižvelgiama i įrenginių ortakio pajungimo skersmens skirtumus. Pirmasis bedimensinis $\pi_{l}$ parametras rodo statinio slègio skirtumo ir dinaminio slègio santyki. Tuo tarpu antrasis parametras $\pi_{2}$ taikomas ištraukiamo oro debito palyginimui su pučiamo vèjo srauto debitu.

Remiantis Buckingham teorema, pastaruosius bedimensinius parametrus sieja funkcinis ryšys: 


$$
\frac{\dot{Q}_{e}}{u d_{i}^{2}}=f\left(\frac{\Delta P_{s}}{\rho u^{2}}\right)
$$

Kitas tarptautiniuose bandymų standartuose (EN 13141-5, 2004) naudojamas rodiklis $c_{p}$. Šis rodiklis rodo ịrenginių ištraukiamo oro potencialą pagal bandymų metu pasiekiamą slègị ịrenginio oro siurbimo kanale. Šiuo atveju tokie bandymai atliekami uždarius įrenginių oro siurbimo angą.

$$
c_{p}=\frac{\Delta P_{s}}{P_{d w}},
$$

čia $P_{d w}$ - vejjo srauto dinaminis slègis, Pa. Nustatomas lygtimi:

$$
P_{d w}=\frac{\rho u^{2}}{2} .
$$

\subsubsection{Aerodinaminès traukos ir pasipriešinimo charakteristiku ivertinimas}

STV savo konstrukcija ir veikimu panašus ị „Savonius“ tipo vejjo jègainę, kurių mentès didžiaja dalimi veikiamos tik aerodinamine traukos jèga (angl. drag force). Šiuo atveju remiantis tokia ịrenginiu panašumo analogija, turbininiams ventiliatoriams atliekami aerodinaminès traukos charakteristikų tyrimai.

Vienas pagrindinių rodiklių rodančių aerodinaminę trauką - traukos koeficientas:

$$
C_{d}=\frac{F_{d}}{P_{d w} \cdot A_{v e}},
$$

čia $F_{d}$ - traukos jèga išilgai veikianti $\mathrm{STV}, \mathrm{N} ; A_{v e}-\mathrm{STV}$ skerspjūvio plotas statmenas vejo srautui, $\mathrm{m}^{2}$.

Atliekant bandymus, traukos jèga veikianti STV nustatoma netiesiogiai. Šiuo atveju visu pirma matuojama traukos jèga veikianti tik oro ištraukimo ortakị. Šis bandymas atliekamas pašalinus iš sistemos STV. Atlikus šiuos matavimus, STV grąžinamas atgal ir atliekamas pilnutinès traukos matavimas su STV bei kartu prie jo prijungtu ortakiu. Tuomet, traukos jèga veikianti tik STV apskaičiuojama pagal šių dviejų bandymų skirtumą:

$$
F_{d}=F_{d t}-F_{d o},
$$

čia $F_{d t}$ - pilnutinè traukos jèga išilgai veikianti STV bei prie jo prijungtą ortakị, $\mathrm{N} ; F_{d o}-$ traukos jèga išilgai veikianti oro ištraukimo ortakị, N. 
Prie aerodinaminių charakteristikų taip pat priskiriamas ịrenginių aerodinaminis pasipriešinimas ištraukiant oro srautą. Šių charakteristikų tyrimai atliekami eksperimentiškai, be vejjo srauto. Bandymų metu įrenginiu oro ištraukimo ortakis sujungimas su oro pūtimo ventiliatoriumi. Tyrimo metu matuojamas ị ịrenginius tiekiamas oro debitas bei statinio slègio oro ištraukimo ortakyje ir išoreje skirtumas. Bendru atveju aerodinaminis pasipriešinimas ištraukiant oro srautą nustatomas lygtimi:

$$
\zeta=1+\frac{\Delta P_{s}}{P_{d}},
$$

čia $\Delta P_{s}$ - statinio slègio ịrenginio oro įtekejjimo kanale ir išorèje skirtumas, $\mathrm{Pa}$; $P_{d}-$ dinaminis slègis įrenginio oro įtekejjimo kanale, $\mathrm{Pa}$.

\subsubsection{Rotoriumi generuojamos galios ịvertinimas}

Siekiant nustatyti nagrinejjamų STV energijos generavimo potencialą, kartu su ištraukiamo oro srauto rodiklių ir aerodinaminių charakteristikų tyrimais, šiame darbe taip pat atliekami ịrenginiu generuojamos galios bandymai. Analizuojant ankstesnius mokslinius darbus pastebèta, jog šiems įrenginiams tokie tyrimai iki šiol nebuvo atliekami.

Šiame darbe, STV generuojamas galios tyrimai atliekami rotoriui mechaniškai sukuriant pasipriešinimo apkrovą. Tam tikslui, STV rotoriaus viršutinė dalis sujungiama metaline ašimi su sukimo momento matavimo prietaisu („Lorenz DR1“). Kitoje sukimo momento prietaiso pusejje įmontuotas apkrovos reguliavimo mechanizmas, kurio apkrova nustatoma atsižvelgiant $i$ bandomojo įrenginio dydį, vejjo greitị bei norimą ịrenginių sukimosi dažnį. Šiuo atveju STV sukimosi dažnis matuojamas optiniu tachometru („Extech RPM33“). 2.5 paveiksle pateikiama STV rotoriaus sukimo momento matavimo stendo schema ir nuotrauka.

STV rotoriaus generuojama galia tiesiogiai priklauso nuo įrenginio sukimo momento ir rotoriaus sukimosi dažnio. Bendru atveju STV rotoriaus generuojama galia apskaičiuojama:

$$
\dot{E}_{S T V}=2 \pi \cdot \frac{\tau \cdot \omega}{60}
$$

čia $\dot{E}_{S T V}-\mathrm{STV}$ generuojama galia, W; $\tau$ - rotoriaus sukuriamas sukimo momentas, $\mathrm{Nm}$; $\omega$ - rotoriaus sukimosi dažnis, RPM. 


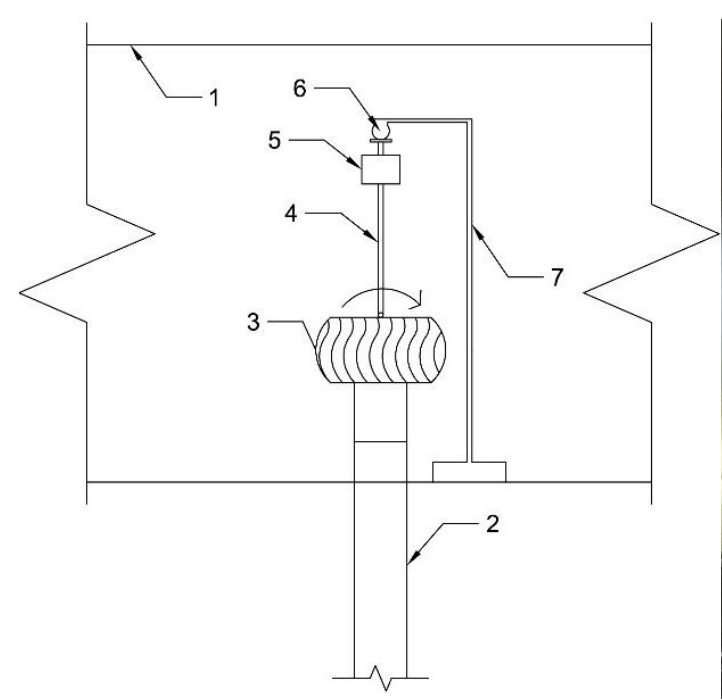

a)

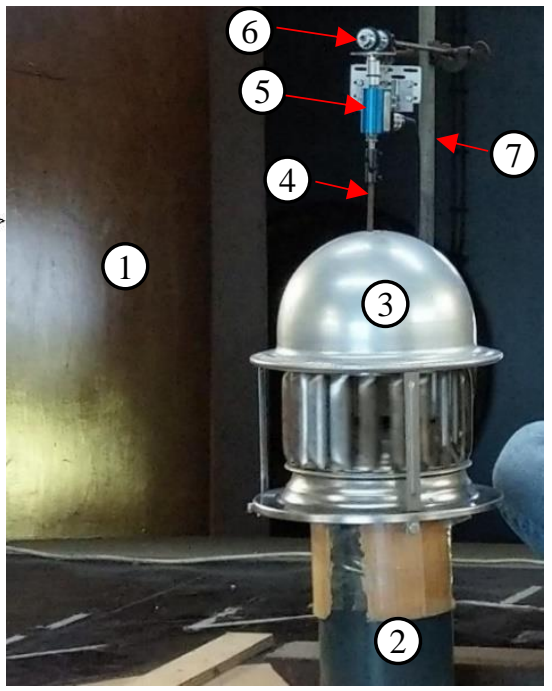

b)

2.5 pav. Turbininio ventiliatoriaus rotoriaus sukimo momento matavimas stendas:

a) stendo schema b) stendo nuotrauka

Fig. 2.5. Turbine ventilator rotor torque measurement stand: a) stand scheme; b) stand picture

Žymèjimai 2.5 paveiksle: 1 - vëjo tunelis; 2 - oro ištraukimo ortakis prijungtas prie STV bei oro srauto matavimo ịrenginio; 3 - bandomas STV; 4 STV rotorių ir sukimo momento matavimo prietaisą jungianti metalinè ašis; 5 sukimo momento matavimo prietaisas; 6 - apkrovos reguliavimo mechanizmas; 7 - sukimo momento matavimo prietaiso tvirtinimo laikiklis.

Remiantis vejo jègainių teorijos panašumu, rotoriaus sukimo momentas tiesiogiai priklauso nuo apkrovos metu kintančio sukimosi dažnio ir pučiamo vèjo greičio. Tokių įrenginių maksimalus sukimo momentas pasiekimas įrenginius apkrovus iki visiško rotoriaus sustabdymo, o rotoriui sukantis laisvai - sukimo momentas nesukuriamas, t. y. lygus 0 . Ivvertinus šiuos teorinius sukimo momento kitimo aspektus bei atsižvelgiant ị anksčiau atliktų eksperimentinių tyrimų metu nustatytą tiesinę STV sukimosi dažnio priklausomybę nuo vejo greičio, maksimali STV generuojama galia gali būti nustatoma remiantis šia funkcine priklausomybe:

$$
\dot{E}_{\max }=f\left(u, \frac{\omega_{\max }}{2}\right),
$$


čia $\dot{E}_{\max }-$ maksimali STV generuojama galia, W; $\omega_{\max }$ - rotoriaus maksimalus sukimosi dažnis įprasto veikimo metu, RPM.

\subsubsection{Eksperimentinių rezultatų neapibrèžtis}

Atliekant eksperimentinius tyrimus bei skaičiuojant charakteringus rodiklius vertinamos tiesioginių ir netiesioginių matavimų paklaidos (Peters, 2001).

Tiesioginiu matavimu metu vertinamos atsitiktinès paklaidos ir sistemingosios paklaidos. Tiesioginių matavimų atsitiktinès paklaidos nustatomas apskaičiuojant rezultatų aritmetinị vidurkị, standartinị vidurkio nuokrypi bei priimant literatūroje randamą Stjudento koeficientą (Čekanavičius \& Murauskas, 2001):

$$
\Delta x_{n, P}=t_{n, P} \cdot s,
$$

čia $\Delta x_{n, P},-$ matuojamo dydžio atsitiktinè paklaida; $t_{n, P}$ - Stjudento koeficientas, esant pasikliovimo tikimybei $P=0,95 ; s$-standartinis vidurkio nuokrypis.

Skaičiuojant atsitiktines paklaidas taip pat vertinamos atskaitymo paklaidos. Šiuo atveju didžiausia galima atskaitymo paklaida yra lygi pusei apvalinimo intervalo. Esant pasikliovimo tikimybei $P$, atskaitymo paklaida skaičiuojama:

$$
\Delta x_{a, P}=P \cdot \frac{h}{2},
$$

čia $h$ - apvalinimo intervalas.

Matavimo prietaisų sistemingosios paklaidos nusakomos tikslumo klase. Matavimo prietaiso sistemingosios paklaidos didžiausia vertè $\Delta x_{r i b}$ nustatoma žinant prietaiso tikslumo klasę $\delta_{r i b}$ ir matavimo ribą $x_{r i b}$ :

$$
\Delta x_{r i b}=\frac{\delta_{r} \cdot x_{r i b}}{100}
$$

Esant pasirinktai pasikliovimo tikimybei $P$, prietaiso sistemingoji neapibrež̌tis apskaičiuojama pagal lygtị:

$$
\Delta x_{p, P}=\left(\frac{t_{\infty, P}}{3}\right) \Delta x_{r i b},
$$

čia $t_{\infty, P}$ Stjudento koeficientas randamas iš lentelès. Pasikliovimo tikimybei esant $P=0,95$, šis koeficientas lygus 2 . 
Galiausiai, tiesioginių matavimų suminè neapibrèžtis apskaičiuojama ivertinus atsitiktines ir sistemingają paklaidas:

$$
\Delta x_{s, P}=\sqrt{\left(\Delta x_{n, P}\right)^{2}+\left(\Delta x_{a, P}\right)^{2}+\left(\Delta x_{p, P}\right)^{2}} .
$$

2.2 lentelëje pateikiami eksperimentų metu matuojami parametrai, naudojami prietaisai, jų tikslumo klasè, minimalus atliekamų matavimų kiekis bei suminė tiesioginių matavimų neapibrèžtis.

2.2 lentelè. Eksperimentų metu matuojami parametrai, matavimo prietaisų tikslumo klasè ir suminè neapibrěžtis

Table 2.2. Experimentally measured parameters, accuracy of measurement devices and total uncertainty

\begin{tabular}{|c|c|c|c|}
\hline $\begin{array}{c}\text { Matuojamas } \\
\text { parametras }\end{array}$ & $\begin{array}{c}\text { Naudojamas matavimo prietaisas ir } \\
\text { tikslumo klase }\end{array}$ & $\begin{array}{c}\text { Minimalus } \\
\text { matavimu } \\
\text { kiekis }\end{array}$ & $\begin{array}{c}\text { Sumine } \\
\text { neapibrěžtis }\end{array}$ \\
\hline$P$ & $\begin{array}{c}\text { Sleggio skirtumo jutiklis ,Ahborn } \\
\text { FDA602S1K“. Tikslumas: } \pm 0,5 \%\end{array}$ & 30 & $\pm 0,89 \mathrm{~Pa}$ \\
\hline$v$ & $\begin{array}{c}\text { Rotacinis anemometras „,Ahborn } \\
\text { FVA915S120“. Tikslumas: } \pm 0,1 \%\end{array}$ & 30 & $\pm 0,061 \mathrm{~m} / \mathrm{s}$ \\
\hline$\omega$ & $\begin{array}{c}\text { Optinis tachometras „Extech RPM33“. } \\
\text { Tikslumas: } \pm 0,05 \%\end{array}$ & 10 & $\pm 2,3 \mathrm{RPM}$ \\
\hline$F$ & $\begin{array}{c}\text { NCIL laboratorijos ortodinamometras. } \\
\text { Tikslumas: } \pm 0,7 \%\end{array}$ & 30 & $\pm 0,013 \mathrm{~N}$ \\
\hline$\tau$ & $\begin{array}{c}\text { Sukimimo memento jutiklis ,Lorenz } \\
\text { DR1“. Tikslumas: } \pm 0,1 \%\end{array}$ & 10 & $\pm 0,0039 \mathrm{Nm}$ \\
\hline$h, w, d$ & Slankmatis. Tikslumas: $\pm 0,0001 \mathrm{~m}$ & 10 & $\pm 0,00024$ \\
\hline
\end{tabular}

Netiesioginių matavimų rezultatų ịvertinimui taikoma vidutinè kvadratinė paklaida:

$$
\Delta y_{v i d . k v .}= \pm \sqrt{\left(\frac{\delta y}{\delta x_{1}} S_{x_{1}}\right)^{2}+\left(\frac{\delta y}{\delta x_{2}} S_{x_{2}}\right)^{2}+\ldots+\left(\frac{\delta y}{\delta x_{n}} S_{x_{n}}\right)^{2}},
$$

čia $y$ - netiesiogiai skaičiuojamas dydis; $S_{x_{1}}, S_{x_{2}}, \ldots S_{x_{n}}$ - tiesiogiai matuojamujų dydžiu $x_{1}, x_{2}, \ldots x_{n}$ vidutinès kvadratinés paklaidos. 
2.3 lentelèje pateikiami darbe taikomi netiesioginiai matavimai ir jų neapibrèžties skaičiavimo rezultatai. Šiuo atveju matavimų neapibrèžtis pateikta atsižvelgiant pagal bandymų metu pasiektą minimalų ir maksimalų vèjo greitị.

2.3 lentelè. Netiesioginių matavimų neapibrèžties vertinimo rezultatai

Table 2.3. Results of propagation of uncertainty

\begin{tabular}{|c|c|c|}
\hline Netiesioginis matavimas & $\begin{array}{c}\text { Neapibréžtis esant } \\
\text { minimaliam vëjo greičiui, } \\
\%\end{array}$ & $\begin{array}{c}\text { Neapibrèžtis esant } \\
\text { maksimaliam vėjo greičiui, } \\
\%\end{array}$ \\
\hline$\dot{Q}_{e}$ & 15 & 1,22 \\
\hline$\pi_{l}$ & 20,1 & 2,54 \\
\hline$\pi_{2}$ & 17,5 & 1,35 \\
\hline$C_{p}$ & 20,1 & 2,54 \\
\hline$C_{d}$ & 35,5 & 6,39 \\
\hline$\zeta$ & 24,1 & 1,6 \\
\hline$\dot{E}$ & 30,6 & 8,9 \\
\hline
\end{tabular}

\subsection{Eksperimentinių tyrimų rezultatai}

Šiame poskyryje pristatomi eksperimentinių tyrimų rezultatai suskirstyti i ištraukiamo oro srauto, aerodinaminio pasipriešinimo, sukimo momento ir generuojamos galios charakteristikų grupes. Ištraukiamo oro srautų charakteristikų rezultatų dalyje lyginamos skirtingų ịrenginių charakteristikos bei pateikiami rezultatai, kurie naudojami daugiakomponentès ịrenginio veikimo koncepcijos kūrimui. Aerodinaminio pasipriešinimo rodiklių dalyje analizuojamas vejo srauto poveikis įrenginių veikimui bei tuo pačiu pateikiamos aerodinaminio pasipriešinimo charakteristikos ištraukiant oro srautą. Sukimo momento ir generuojamos galios poskyryje pateikiami tik STV ịrenginių rezultatai, kuriais vertinamas energijos generavimo potencialas.

\subsubsection{Ištraukiamo oro srauto charakteristikos}

Atlikus eksperimentinius tyrimus nustatyta, kad STV ištraukiamas oro srautas turi funkcinę priklausomybę nuo vèjo greičio bei statinio slègio skirtumo tarp vėdinamos patalpos ir išorès. Siekiant geriau suprasti kompleksinę vejjo greičio ir statinio slègio funkcinę priklausomybę, 2.6 paveiksle pateiktas trimatis grafikas, 
kuriame absoliučiomis vertėmis galima matyti STV2 ištraukiamo oro srauto kitimą dèl šių dviejų faktorių.

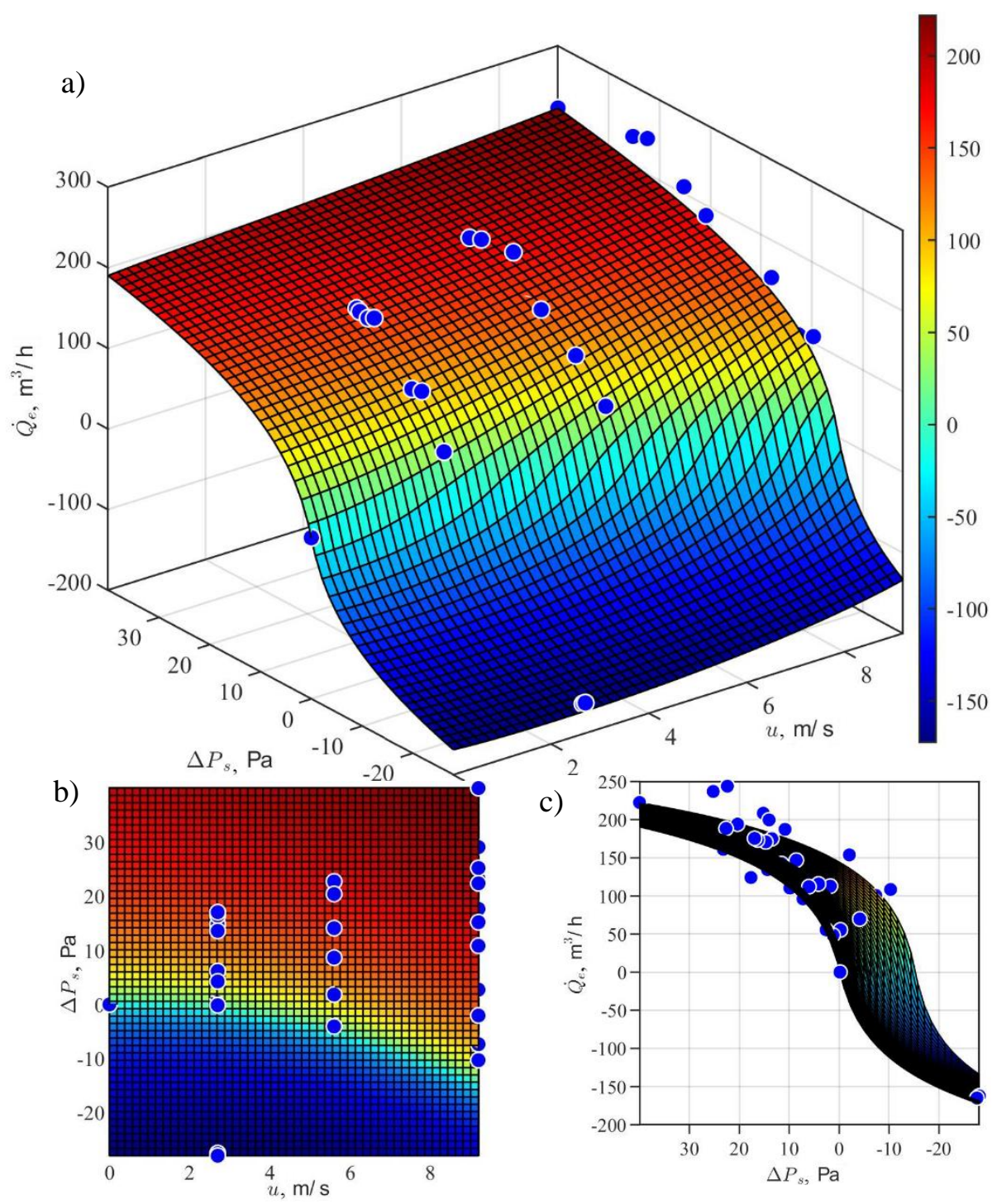

2.6 pav. STV2 ištraukiamo oro srauto kitimas esant skirtingoms vėjo greičio ir statinio slègio sąlygoms: a) erdvinis grafikas; b) projekcija iš viršaus; c) projekcija iš šono

Fig. 2.6. Extracted airflow performance of RTV2 under variable wind speed and static pressure conditions: a) three-dimensional graph; b) top view; c) side view 
Pateiktame grafike mėlynos spalvos taškai rodo eksperimentinių tyrimų duomenis, o spalvotas paviršius sudarytas remiantis šiais duomenimis. Viršutinejje paveikslo dalyje (a) pateikto erdvinio grafiko $x$ ir $y$ ašyse atitinkamai parodytas vejjo greičio kitimas bei statinio slègio vėdinamoje patalpoje iš išorẻje skirtumas. İrenginiu ištraukiamas oro srautas pateiktas $z$ ašyje, o jo vertès gali būti nustatomos pagal dešinèje pusèje pateiktą legendą.

Šio paveikslo apatinèje kaireje pusejje (b) parodytas grafikas rodo erdvinio grafiko projekciją iš viršaus. Grafiko rezultatai gali būti analizuojami pagal vejo greičio, statinio slègio skirtumo ašių skaitines vertes bei naudojantis ta pačia spalvota ištraukiamo oro srauto legenda. Paveikslo apatinèje dešinèje pusèje (c) pateiktas grafikas rodo erdvinio grafiko rezultatu projekciją statinio slègio skirtumo ir ištraukiamo oro srauto ašims.

Analizuojant rezultatus matoma, jog priklausomai nuo bandymų sąlygų, STV2 ištraukiamas oro srautas buvo $-160 \mathrm{~m}^{3} / \mathrm{h}-220 \mathrm{~m}^{3} / \mathrm{h}$ diapazone, statinio slègio vėdinamoje patalpoje ir išoreje skirtumas $-39 \mathrm{~Pa}-41 \mathrm{~Pa}$ diapazone, o vèjo srautas siekè nuo $0 \mathrm{~m} / \mathrm{s}$ iki $9,2 \mathrm{~m} / \mathrm{s}$. Pateikti ištraukiamo oro srauto rezultatai akivaizdžiai rodo, jog vejjo greitis bei statinio slègio skirtumas yra svarbūs faktoriai šiu įrenginių funkcionalumui. Be to, esant nepalankioms statinio slègio skirtumo ir pučiamo vẻjo greičio sąlygoms, gali susidaryti situacija, kai vëjo srautas patenka i STV oro siurbimo kanalą ir dèl to sutrinka védinimo funkcionalumas.

Remiantis šio tyrimo eksperimentiniais duomenimis ir pritaikius „Matlab“ duomenų apdorojimo paketus nustatyta, kad apytiksliam STV2 ištraukiamo oro srauto apskaičiavimui galima taikyti tokio tipo empirinę lygtị:

$$
\dot{Q}_{e}=a \cdot \operatorname{sign}\left(b \cdot \Delta P_{s}+c \cdot u^{2}\right) \cdot\left(\log 10\left(1+\frac{\left|b \cdot \Delta P_{s}+c \cdot u^{2}\right|}{10^{c \cdot \log 10(1 /(u+1))}}\right)\right),
$$

čia $\dot{Q}_{e}-$ įrenginiu ištraukiamas oro srautas, $\mathrm{m}^{3} / \mathrm{h} ; a, b, c$-empiriniai koeficientai, nustatyti pagal eksperimentinių tyrimų duomenis. Tiriamojo STV2 atveju koeficientai $a=148,8 ; b=0,451 ; c=0,081 ; u$-vejo greitis, $\mathrm{m} / \mathrm{s} ; \Delta P_{s c}-$ statinio slègio skirtumas tarp vėdinamos patalpos ir lauko oro, $\mathrm{Pa}$;

Pateikta empirinė lygtis galioja tik STV2 tipo įrenginiui, tuo tarpu kitiems ịrenginiams gali skirtis empiriniai koeficientai ir lygties išraiška. Tokiu būdu nustatytos funkcinès priklausomybès palankios atliekant kiekybę analizę, kuomet nustatomos pasirinkto ịrenginio absoliučiosios ištraukiamo oro srauto vertès pagal vejjo greičio ir statinio slègio duomenis. Tačiau tokių tyrimų duomenys ir skaičiavimo rezultatų pateikimas apsunkina kokybinị skirtingų îrenginių 
lyginimą. Kokybiniam skirtingų įrenginių palyginimui, šiuo atveju pasirinktas bedimensine Buckingham $\pi$ analize nustatytų parametrų taikymas.

2.7 paveiksle pateiktas bedimensinę analizę iliustruojantis grafikas, kuriame bedimensiniu parametrų vertemis galima matyti visų bandytų įrenginių ištraukiamo oro srauto potencialą, esant skirtingiems statinio slègio ir pučiamo vejjo greičio santykiams. Be to, remiantis šia teorema sudarytais bedimensiniais parametrais, įrenginiai lyginami atsižvelgiant $\mathfrak{i}$ ortakio pajungimo skersmens skirtumus.

Kompleksiškai vertinant vejo greičių ir statinio slègio skirtumų kitimą matoma, kad geriausią ištraukiamo oro rezultatą pasiekia STV2 (rotoriaus mentės vertikalios ašies kryptimi tiesios). Palyginimui pasirinkus atvirą ortakị, STV2 ištraukiamas oro srautas gali būti iki $8 \%$ didesnis. Priklausomai nuo vejjo greičio ir statinio slègio sąlygų, visų kitų įrenginių ištraukiamo oro srauto veiksmingumas gali būti mažesnis iki $30 \%$.

Analizuojant STV1 (rotoriaus mentės lenktos vertikalios ašies kryptimi) tyrimų duomenis matoma, kad mažas šio įrenginio rotorius ir sąlyginai didelis siurbimo angos skerspjūvio plotas lemia tai, kad ịrenginys veikia prasčiausiai iš visų bandytų STV. Tuo tarpu STV3 (rotoriaus mentès lenktos vertikalios ašies kryptimi), būdamas panašios konstrukcijos i STV1, rodo šiek tiek geresni veiksmingumą dèl didesnių tarpų tarp rotoriaus menčių.

Vertinant bandyto deflektoriaus rezultatus pastebima, kad virš įrenginio ịrengtas nuo lietaus apsaugantis stogelis mažina oro siurbimo rezultatą iki $20 \%$ lyginant su atviru ortakiu. Atliekant eksperimentinius tyrimus pastebėta, kad nuo tam tikro siurbiamo oro greičio prasideda ištekančio oro srauto interferencija su apsaugine lietaus konstrukcija ir dẻl to padidejjus aerodinaminiam pasipriešinimui - sumažejja ištraukiamo oro srauto efektyvumas.

Tyrimų metu sudarius sąlygas vèjo srauto ịsiurbimui pastebèta, kad visi bandyti STV ịrenginiai stipriai sumažina ịsiurbiamo vejjo srauto kiekị lyginant su atviru ortakiu. Vertinant absoliučiuosius rodiklius, iki $55 \%$ mažesnis įsiurbtas oro debitas nustatytas STV1 ịrenginyje. STV2 ir STV3 įrenginiais ịsiurbimas oro srautas sumažinamas iki $45 \%$. Tuo tarpu vertinant deflektoriaus atsparumą oro srauto įsiurbimui matoma, kad įrenginio konstrukcija lemia tai, kad įsiurbiamo oro srauto debitas gali būti mažesnis iki $25 \%$ lyginant su atviro tipo ortakiu. 


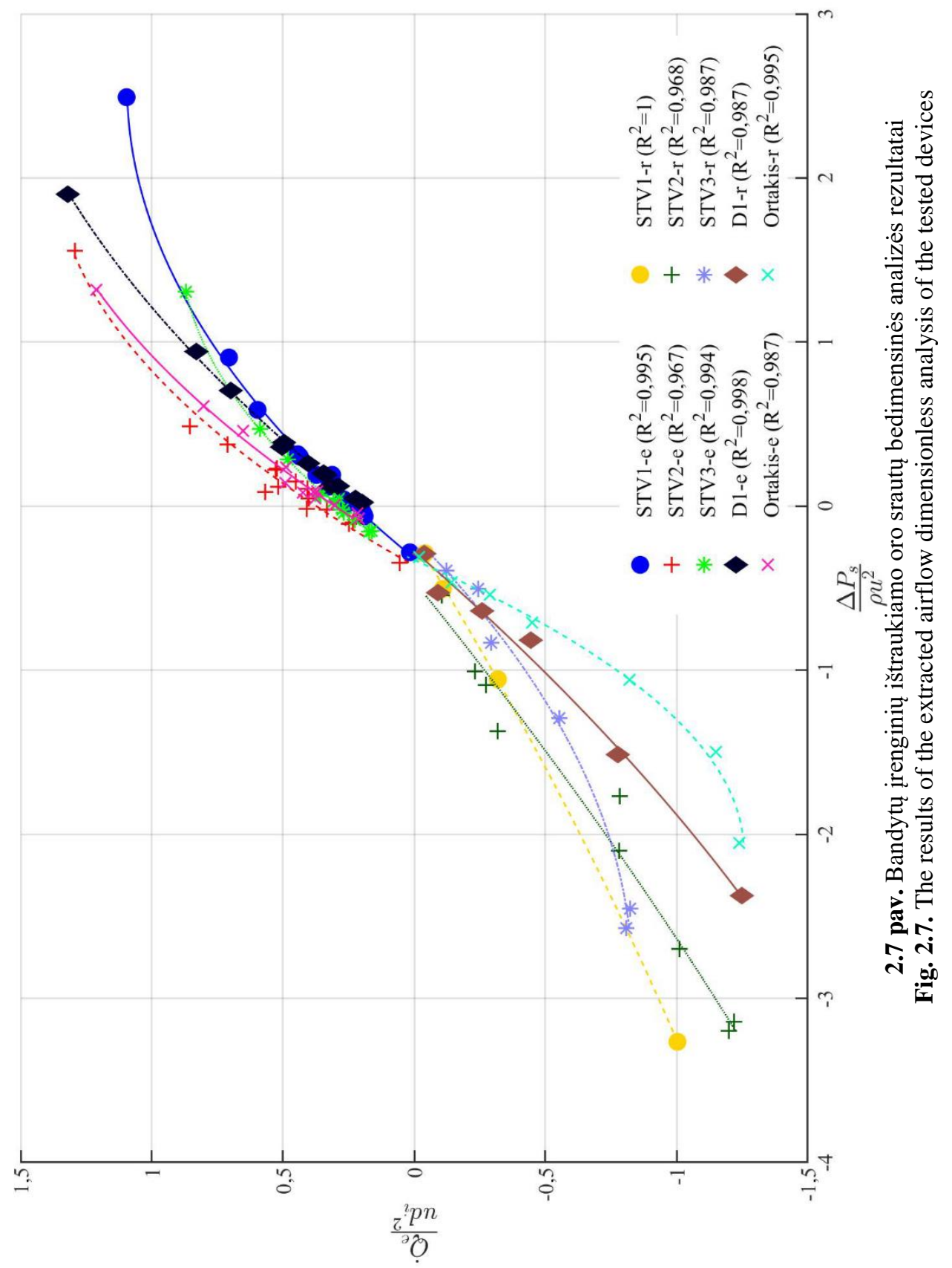


Žymèjimai 2.7 paveikslo legendoje: „-e“ ir „,-r“ atitinkamai reiškia ištraukiamo ir ịsiurbiamo oro srautų tekejjimo kryptị; R2 - bandymų rezultatų determinacijos koeficientas. Atliekant bandymus vejo tunelyje, vejjo greitis reguliuojamas trimis pastoviomis pakopomis, tuo tarpu statinio slegio reguliavimas vėdinamoje patalpoje ribotas ir kiekvieno bandymu atveju skiriasi. Dèl šios priežasties, kiekvienam STV skiriasi $\mathrm{x}$ ašies kryptimi pateiktų duomenų vertès.

Siekiant susieti eksperimentinių tyrimų duomenis su toliau pristatoma daugiakomponente įrenginio veikimo koncepcija, 2.8 paveiksle pateikiamos bandytų STV ištraukiamo oro srauto ir sukimosi dažnio priklausomybės nuo vejjo greičio. Šiuo atveju rezultatai pateikiami esant ịprasto veikimo ir sustabdyto veikimo režimams. Be to, visi kiti toliau pristatomi STV bandymų rezultatai, kuriuose pateikiamos absoliučiosios ištraukiamo oro srauto vertès, atlikti suvienodinus védinimą patalpą imituojančios kameros ir vẻjo tunelio statinius slègius.

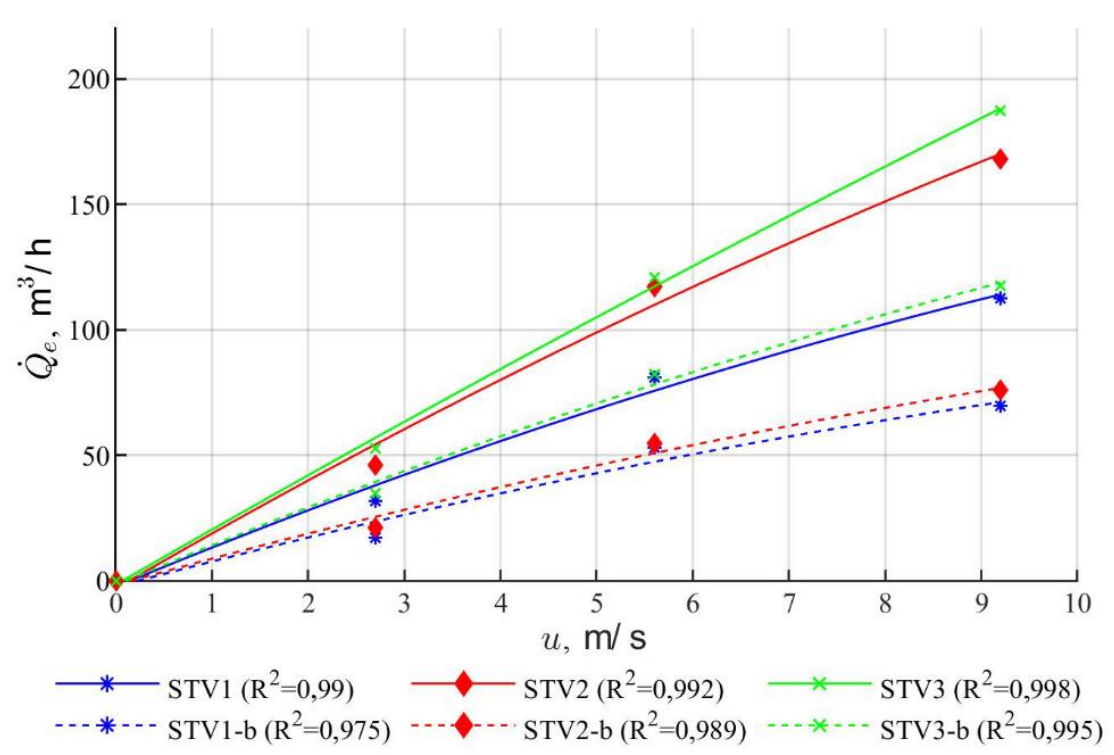

2.8 pav. İrenginių ištraukiami oro srautai esant ịprastam ir sustabdytam rotoriaus veikimui

Fig. 2.8. Extracted airflow by devices under normal ant stopped rotor conditions

Grafike pateiktos punktyrinès kreivès ir STV žymėjimas su prierašu „-b“ rodo sustabdytų STV rotorių rezultatus. Ištisinès kreivès rodo ịprasto STV veikimo rezultatus. 
Kiekybiškai vertinant bandytų STV rezultatus matoma, kad įprasto veikimo metu, didžiausią ištraukiamą oro srautą pasiekia STV3 ịrenginys. Nedaug mažesnis rezultatas pasiekiamas STV2 įrenginiu, o STV1 šis rezultatas mažesnis apie 30-40\%. Esant 9,2 m/s vejjo greičiui, vienodam statinio slègio skirtumui tarp védinamos patalpos ir išorès, maksimalus STV1 ištraukiamas oro srautas siekè $116 \mathrm{~m}^{3} / \mathrm{h}, \mathrm{STV} 2-171 \mathrm{~m}^{3} / \mathrm{h}$, o STV3 $-183 \mathrm{~m}^{3} / \mathrm{h}$.

Šiuo atveju esant vienodam vėdinamos patalpos ir lauko oro statiniams slègiams, bandytų STV ištraukiamo oro srauto apskaičiavimui gali būti taikoma antrojo laipsnio empirinè lygtis:

$$
\dot{Q}_{e}=a \cdot u^{2}+b \cdot u+c,
$$

čia $\dot{Q}_{e}-\mathrm{STV}$ ištraukiamas oro srautas, $\mathrm{m}^{3} / \mathrm{h} ; u$ - vejjo greitis, $\mathrm{m} / \mathrm{s}$. Šiuo atveju empirinè lygtis galioja kai vëjo greitis yra didesnis už $0,5 \mathrm{~m} / \mathrm{s} ; a, b, c$-empiriniai koeficientai, kurių vertės pateiktos žemiau esančioje 2.4 lentelèje.

2.4 lentelė. Turbininių ventiliatorių ištraukiamo oro srauto empirinès lygties koeficientai Table 2.4. Coefficients of the empirical equation of turbine ventilators extracted airflow

\begin{tabular}{|c|c|c|c|}
\hline \multirow{2}{*}{$\begin{array}{c}\text { Irenginio } \\
\text { żymejjimas }\end{array}$} & $\mathrm{a}$ & $\mathrm{b}$ & $\mathrm{c}$ \\
\cline { 2 - 4 } & $-0,453$ & 17,75 & $-3,139$ \\
\hline STV1 & $-0,198$ & 20,34 & $-2,418$ \\
\hline STV2 & $-0,251$ & 22,78 & $-1,699$ \\
\hline STV3 &
\end{tabular}

Vertinant skirtingų bandymo sąlygų rezultatus nustatyta, jog atlikus visišką ịrenginių rotorių sustabdymą, oro siurbimas išlieka. Šiuo atveju pučiant vejjo srautui ir nesisukant ịrenginių rotoriams, vèjo sukuriama ežekcija sudaro apie $50-65 \%$ viso ištraukiamo oro srauto. Likusią dalị prideda vèjo ịsukamas rotorius, veikiantis kaip elektra varomas ventiliatorius.

Toliau esančiame 2.9 paveiksle pateikiami pagal „EN 13141-5“ nustatyti bandytu įrenginių $c_{p}$ rodikliai. Ištraukiamo oro potencialą charakterizuojantys rodikliai $c_{p}$ leidžia kokybiškai palyginti ịrenginių veiksmingumą, tačiau kiekybiškai nustatyti ištraukiamo oro debitą nèra galima.

Šiuo atveju mažesnès rodiklių vertès rodo didesnị įrenginio ištraukiamo oro potencialą. Pagal atliktų bandymų rezultatus nustatyta, kad rezultatai turi tiesiogini ryši su bedimensinès Buckingham $\pi$ analizès rezultatais. Didžiausią ištraukiamo oro srauto potencialą rodo STV2 įrenginys. Mažiausias potencialas nustatytas STV1 įrenginiui. Skirtumas tarp šių rezultatų siekia apie $55 \%$. 


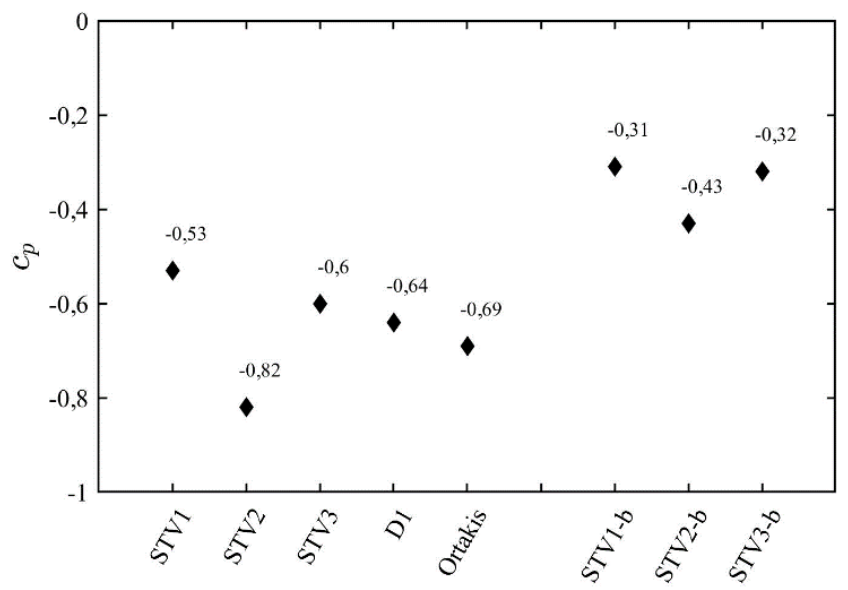

2.9 pav. Bandytų ịrenginių $c_{p}$ rodiklių palyginimas

Fig. 2.9. Comparison of tested devices $c_{p}$ factors

2.9 paveiksle pateikti STV žymėjimai su prierašu ,-b“ rodo sustabdytų STV rotorių rezultatus.

Lyginant STV iprasto ir sustabdyto rotoriaus veikimo $c_{p}$ rodiklius matoma, kad rezultatų skirtumas yra panašus i anksčiau pateiktus rezultatus su absoliučiomis ištraukiamo oro srauto vertèmis (2.8 pav.). Šiuo atveju matoma kad skirtumas siekia nuo $50 \%$ iki $70 \%$.

2.10 paveiksle pateikiama Vilnius Tech laboratorijoje bandyto STV1 ištraukiamo oro srauto rezultatu palyginimas ir analize, esant ịprastinio veikimo ir rotoriaus sukimo elektros varikliu bandymų sąlygoms.

Vertinant STV1 bei kitų STV sukimosi dažnio rezultatus nustatyta, kad įrenginių rotoriaus sukimasis prasideda vejjo greičiui viršijus apie $2 \mathrm{~m} / \mathrm{s}$. Be to, nustatyta, kad įrenginių sukimosi dažnio priklausomybè nuo vejjo greičio yra tiesinè. Remiantis bandymų duomenimis, ši priklausomybẻ STV1 įrenginiui gali būti aprašoma empirine lygtimi:

$$
\omega=65,55 \cdot u-79,94,
$$

čia $\omega-\mathrm{STV}$ rotoriaus sukimosi dažnis, RPM. Lygtis galioja kai $u>2 \mathrm{~m} / \mathrm{s}$.

Analizuojant skirtingų STV1 bandymų režimų rezultatus matoma, kad pasiekus vienodus sukimosi dažnius, didesnis ištraukiamas oro srautas susidaro, kai varomoji jèga yra vejjas. 


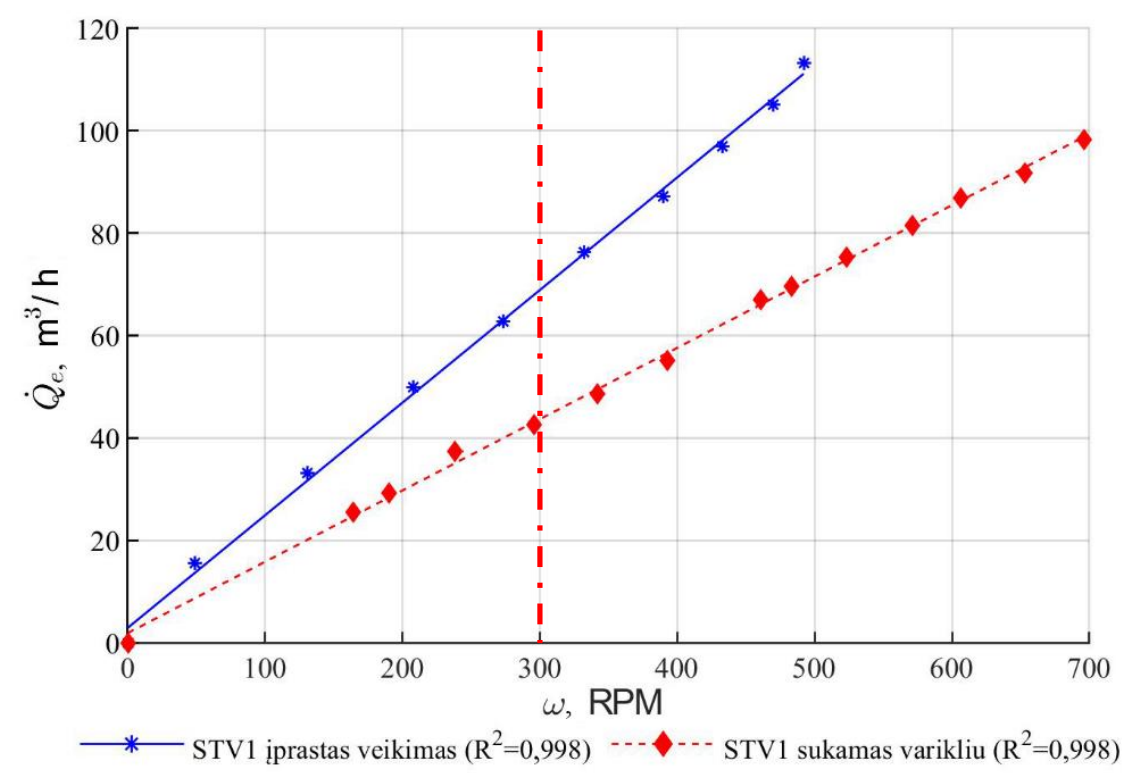

2.10 pav. STV1 ištraukiamo oro srauto palyginimas tarp ịprasto veikimo ir rotoriaus sukimo elektros varikliu

Fig. 2.10. Comparison of RTV1 extracted airflow between regular operation and rotor's rotation by an electric motor

Šiuo atveju rezultatams palyginti laisvai pasirinkus 300 sūkiu per minutę atskaitą (žymima vertikalia brūkšnine linija) apskaičiuota, jog ịprasto veikimo sąlygomis, STV1 gali ištraukti apie $67 \%$ daugiau oro srauto nei veikdamas su elektros varikliu. Norint pasiekti vienodus ištraukiamojo oro srautus, ịrengini sukant varikliu reikalingas didesnis sukimosi dažnis nei sukant tik vejjo srautu.

\subsubsection{Aerodinaminès traukos ir pasipriešinimo rodikliai}

Šiame poskyryje pateikiamos STV aerodinaminès traukos charakteristikos bei visų bandytų ịrenginių aerodinaminis pasipriešinimas ištraukiant oro srautą. Aerodinaminès traukos charakteristikos nagrinèjamos siekiant ịvertinti vejjo poveikị STV veikimui bei atsižvelgiant ị tai, kad mokslinèje literatūroje paskelbta nedaug tokio tipo tyrimų. Kadangi bandyti įrenginiai didžiaja dalimi veikia tik dèl aerodinaminès traukos jègos, tyrime analizuojamos tik išilginès STV veikiančios jègos.

Atliekant aerodinaminès traukos tyrimus vejjo tunelyje, $R e$ skaičius svyravo nuo $2,4 \cdot 10^{4}$ iki $1,6 \cdot 10^{5} .2 .11$ paveiksle pateiktas STV veikiančių traukos jègu palyginimo grafikas. 


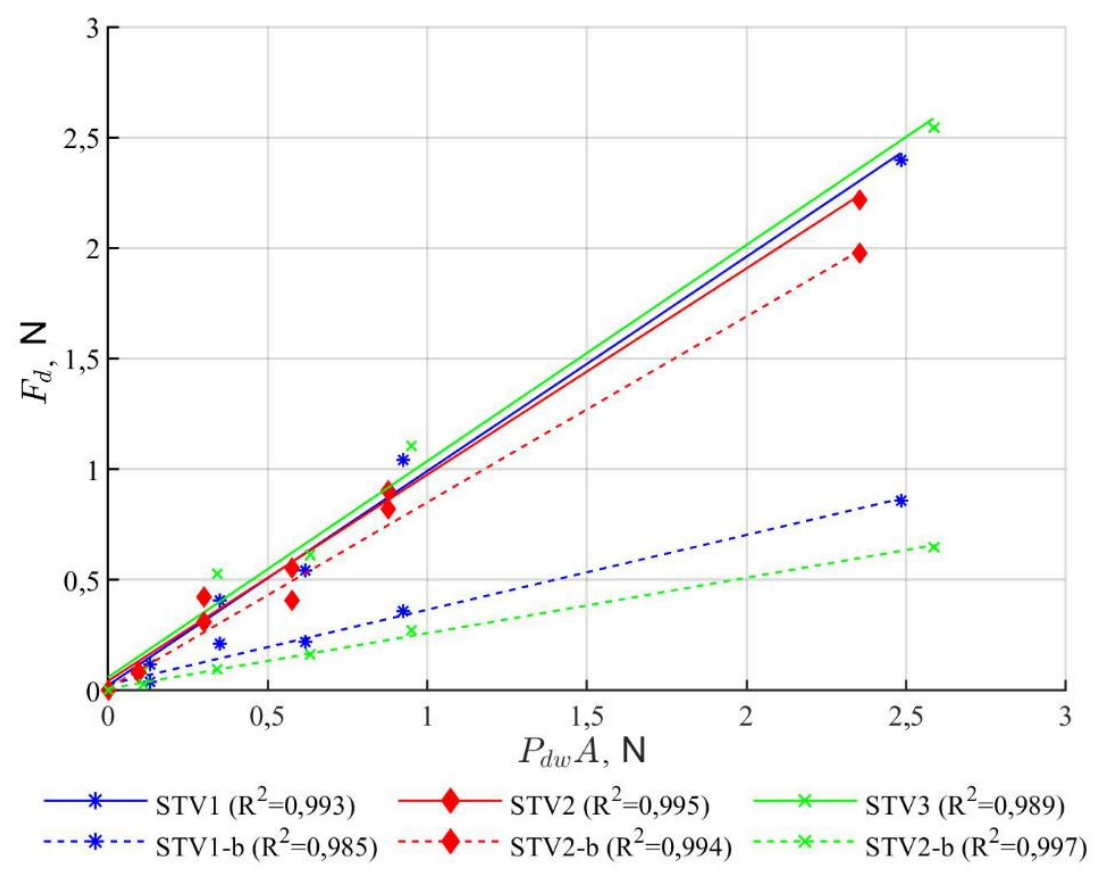

2.11 pav. Turbininius ventiliatorius veikiančių traukos jëgų palyginimas Fig. 2.11. Comparison of drag forces acting turbine ventilators

2.11 paveiksle pateikti STV žymèjimai su prierašu ,-b“ rodo sustabdytų STV rotorių rezultatus. $\mathrm{R}^{2}$ - bandymų rezultatų determinacijos koeficientas.

Remiantis eksperimentinių tyrimų rezultatais matoma, kad ịrenginius veikiančios maksimalios vejjo srauto aerodinaminès traukos jègos siekè iki $2,5 \mathrm{~N}$. Be to, vertinant aerodinaminès traukos kitimą matoma, kad rezultatai turi tiesinę priklausomybę. Žvelgiant ị ịprasto veikimo ir sustabdyto rotoriaus rezultatus matoma, kad visais atvejais, sustabdžius rotorių aerodinaminė trauka sumažèja. 2.12 paveiksle pateikiami pagal šiuos duomenis apskaičiuoti aerodinaminès traukos koeficientai $c_{d}$. 


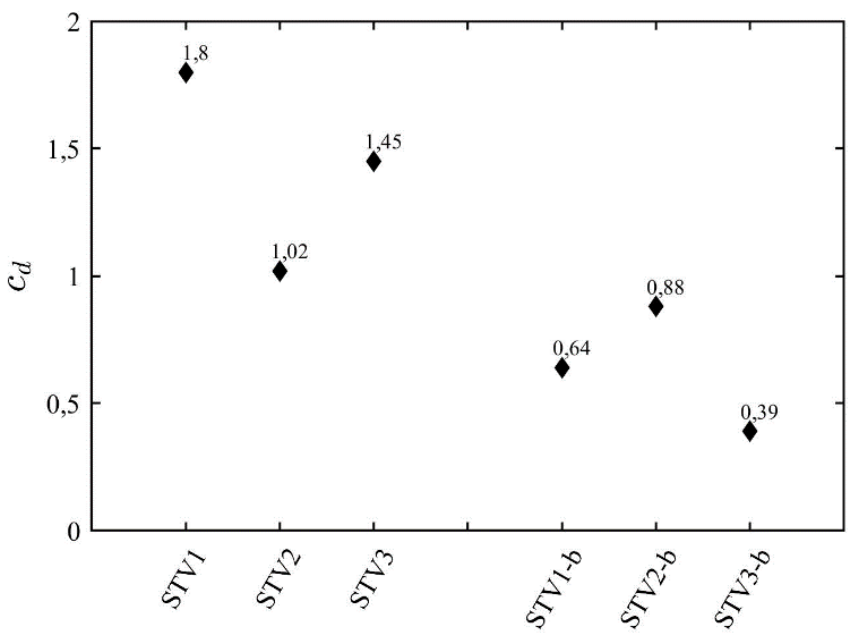

2.12 pav. Bandytų įrenginių traukos koeficientų palyginimas

Fig. 2.12. Comparison of drag coefficients of tested devices

Aerodinaminès traukos koeficientų rezultatai rodo, kad ịprasto veikimo metu didžiausia aerodinaminė trauka tenka STV1, o mažiausia trauka veikia STV2 įrenginį. Šiuo atveju aerodinaminès traukos koeficientai STV1, STV2, STV3 atitinkamai lygūs $1,8,1,02$ bei 1,45 .

Analizuojant skirtingų bandymų sąlygų rezultatus matoma, kad sustabdžius STV rotorius, aerodinaminè trauka gali sumažèti iki 3 kartų. Didžiausias skirtumas pastebimas STV1 ir STV3 įrenginiuose, kurių rotoriaus konstrukcija sudaryta iš vertikalios ašies kryptimi lenktų menčių. Bandymų metu pastebeta, kad STV veikimo metu dèl rotorių sukimosi ir ištraukiamo oro srauto susidaro įrenginio konstrukciją veikianti išcentrinè jèga. Dèl šios priežasties padidèja aerodinaminès traukos jèga. Vertinant STV2 skirtingo veikimo rezultatus matoma, kad aerodinaminè traukos skirtumas siekia apie $16 \%$.

2.13 paveiksle pristatomi bandytų irenginių aerodinaminio pasipriešinimo koeficientai esant skirtingoms veikimo sąlygoms. Analizuojant aerodinamini pasipriešinimą ištraukiant oro srautą matoma, kad didžiausi slègio nuostoliai susidaro STV3 įrenginyje, o mažiausi slègio nuostoliai susidaro deflektoriuje. Vertinant tik STV rezultatus nustatyta, jog mažiausias aerodiniaminis pasipriešinimas susidaro STV2 ịrenginyje. Šiuo atveju aerodinaminio pasipriešinimo koeficientai STV1, STV2, STV3, D atitinkamai lygūs 2,42, 1,31, 2,65 bei 1,22 . 


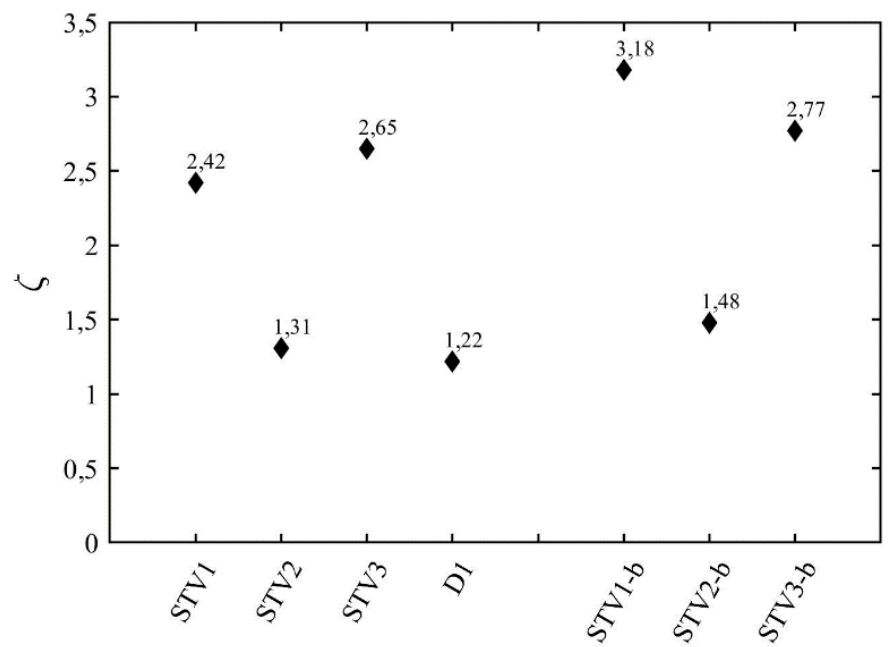

2.13 pav. Bandytų įrenginių aerodinaminio pasipriešinimo koeficientų palyginimas

Fig. 2.13. Comparison of minor loss coefficients of tested rooftop ventilators

Analizuojant sustabdytų STV rotorių rezultatus pastebima, kad visais atvejais tokios sąlygos padidina aerodinaminị pasipriešinimą. Sustabdžius STV rotorius, šis skirtumas siekia nuo $13 \%$ iki $31 \%$. Šie rezultatai rodo, kad turètų būti vengiamas sąlygos kuomet įrenginių rotoriai visiškai sustoja.

\subsubsection{Sukimo momento ir generuojamos galios charakteristikos}

Šioje rezultatų dalyje pateikiama STV eksperimentinių bandymų dalis susijusi su STV sukimo momento matavimais ir šio îrenginio generuojamos galios skaičiavimais. STV sukimosi ašyje ịrengus sukimo momento matavimo prietaisą, bandymai atlikti esant trims skirtingiems vejjo greičiams bei vienodiems statiniams slėgiams vėdinamoje patalpoje ir vejjo tunelyje. Bandymų metu sukimo momentas matuojamas sukuriant skirtingas apkrovos STV sukimosi ašiai. Be to, tuo pačiu metu, optiniu tachometru matuojami STV sukimosi dažniai.

2.14 paveiksle pateikiamas grafikas, rodantis bandytų STV sukimo momentų priklausomybes nuo sukimosi dažnio ir vejjo greičio. 


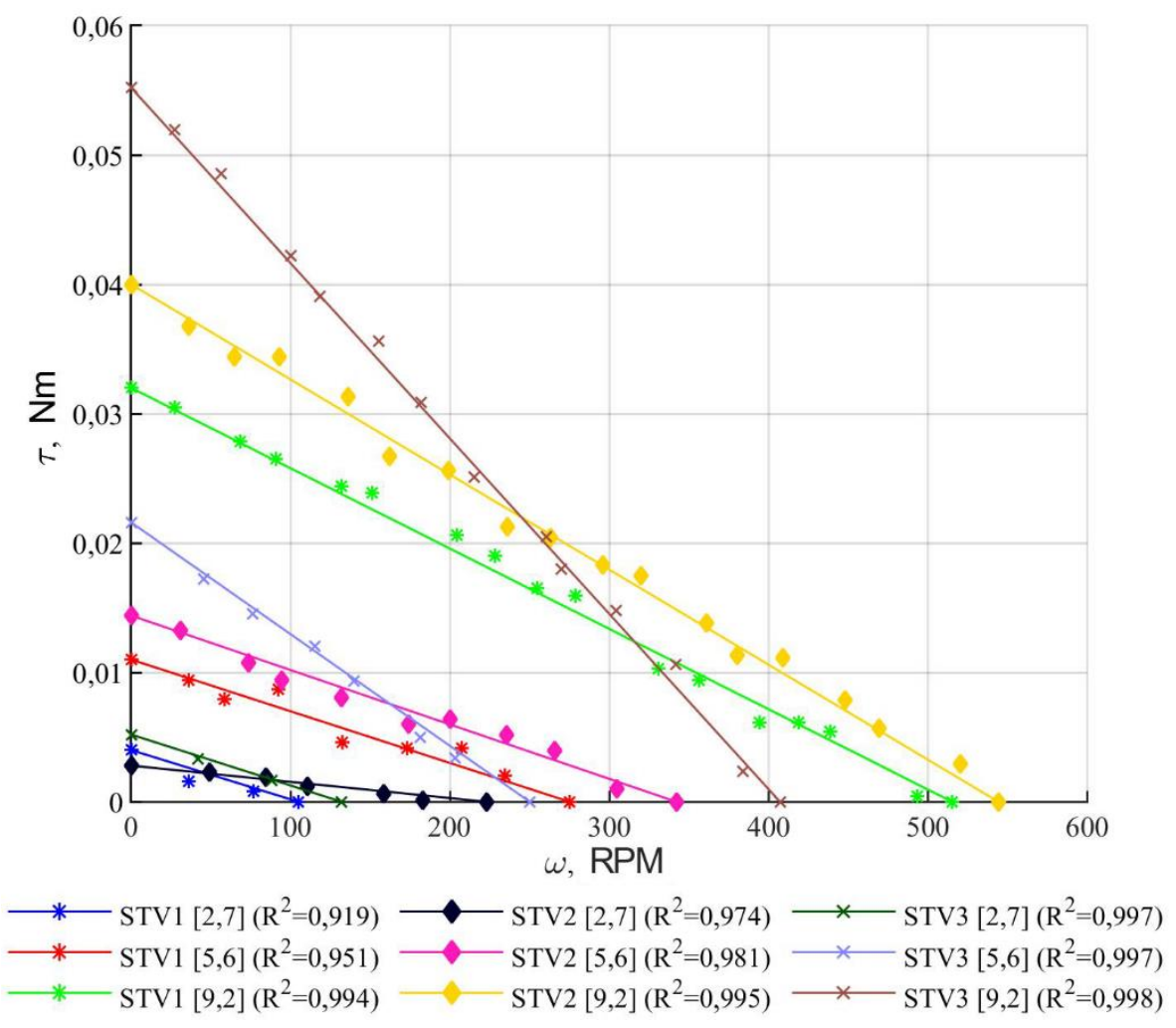

2.14 pav. Turbininių ventiliatorių rotorių sukuriami sukimo momentai esant skirtingiems vejjo greičiams

Fig. 2.14. Torques of rotors of turbine ventilators under different wind speed

Žymėjimai 2.14 paveikslo grafike: [ ] - laužtiniuose skliaustuose nurodytas skaičius rodo vëjo greiti, $\mathrm{m} / \mathrm{s} ; \mathrm{R}^{2}$ - bandymų rezultatų determinacijos koeficientas.

Sukimo momento matavimo rezultatai rodo, kad STV sukuriamas sukimo momento kitimas nuo sukimosi dažnio yra tiesinis. Šiuo atveju didžiausios sukimo momento vertès pasiekiamos sustabdžius įrenginių rotorius. Vertinant atskirų ịrenginių generuojamus sukimo momentus matoma, kad didžiausi sukimo momentai pasiekiami STV3 įrenginyje. Šiuo atveju esant maksimaliam 9,2 m/s vejjo greičiui ir sustabdytam rotoriui, sukimo momentas siekia apie $0,055 \mathrm{Nm}$. Pagal kitu įrenginių duomenis matoma, kad esant toms pačioms bandymų sąlygoms, STV2 maksimalus sukimo momentas yra apie 0,04 Nm, o mažiausią rotorių turinčio STV1 - 0,032 Nm.

2.15 paveiksle pateikiami bandytu STV generuojamos galios skaičiavimo rezultatai, nustatyti pagal rotoriaus sukimosi dažnius ir atitinkamai nustatytas 
sukimo momento vertes. Šiame grafike tuo pačiu pateikiamos ištraukiamo oro srauto kitimo kreivès, esant skirtingiems rotorių apkrovimams ir vejjo greičiams.

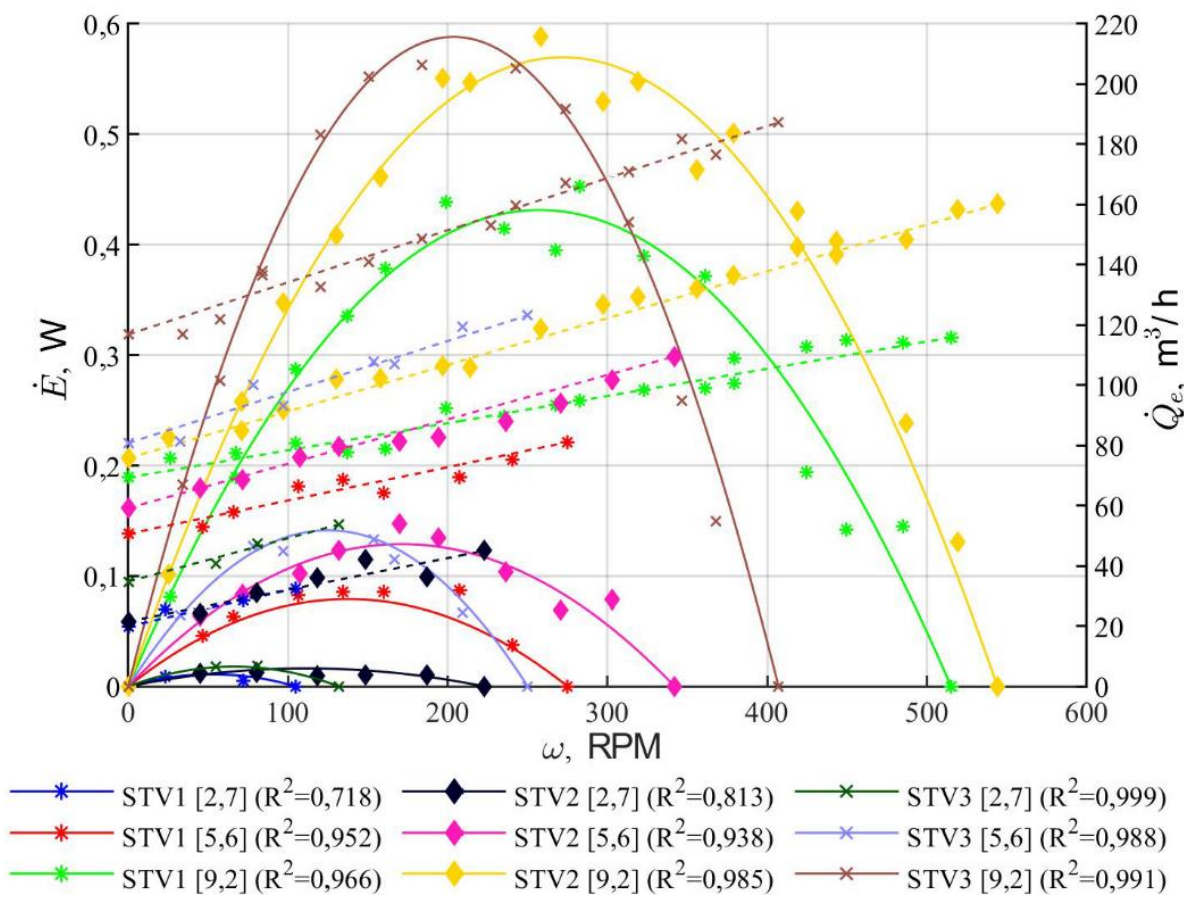

2.15 pav. Turbininių ventiliatorių generuojamos galios ir ištraukiamo oro srautų kitimas, esant skirtingiems vèjo greičiams

Fig. 2.15. Generated power and extracted airflow performance of turbine ventilators under different wind speed

Šiais bandymais nustatyta, kad esant $9,2 \mathrm{~m} / \mathrm{s}$ vejjo greičiui, pasirinkti STV gali generuoti apie $0,6 \mathrm{~W}$ maksimalią galią, kai jų sukimosi dažnis sumažèja pusiau. Esant dideliam vejjo greičiui ir didesniam nei numatyta ištraukiamam oro srautui, šią perteklinę energiją įrenginyje galima akumuliuoti. Šiuo atveju siekiant maksimalios akumuliavimui suteikiamos galios, STV sukimosi dažnis turi būti sumažinamas apie $50 \%$. Visgi, kartu vertinant ištraukiamo oro srauto kitimą, matoma, kad bandytų įrenginių ištraukiamas oro srautas gali sumažèti apie $20 \%$. Kai kuriais atvejais, toks STV rotoriaus ašies apkrovimas nèra galimas, nes siurbiamas oro srautas tampa per mažas ir dèl to neužtikrinamas patalpos vèdinimo poreikis.

Remiantis ankstesnio grafiko rezultatais, 2.16 paveiksle sudarytas papildomas grafikas, rodantys bandytų STV maksimalios galios kitimą nuo vèjo 
greičio. Grafike taip pat parodytas ištraukiamo oro srauto kitimas, esant šioms irenginių veikimo sąlygoms.

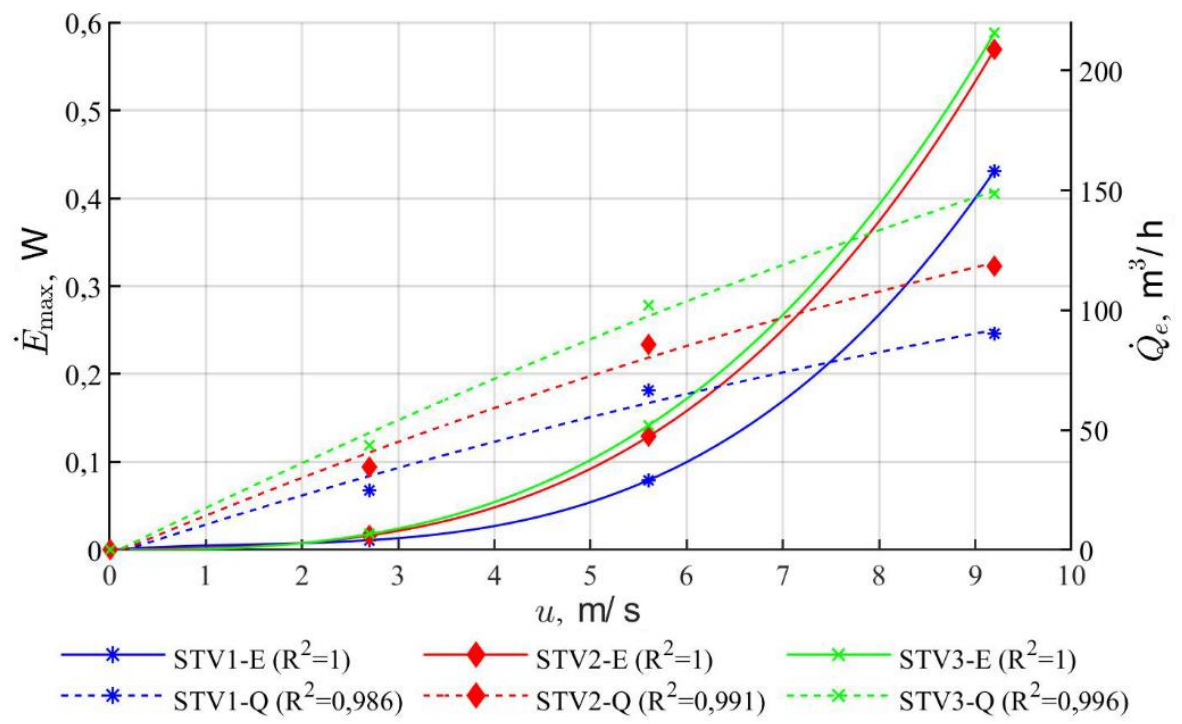

2.16 pav. Turbininių ventiliatorių maksimalios generuojamos galios ir ištraukiamo oro srautų kitimas esant skirtingiems vejjo greičiams

Fig. 2.16. Variation of maximum generated power and extracted airflow of turbine ventilators under variable wind speed

Pagal grafike pateiktus rezultatus nustatyta, kad maksimalus STV generuojamos galios kitimas atitinka kubinę priklausomybę. Matyti, jog įrenginiui veikiant energijos akumuliavimo režimu, vejo srauto greitis yra esminis faktorius. Šiuo atveju naudojant STV2 ir esant $9,2 \mathrm{~m} / \mathrm{s}$ vejjo greičiui būtų galima generuoti apie $0,6 \mathrm{~W}$ galią, o ištraukiamas oro srautas siektų apie $120 \mathrm{~m}^{3} / \mathrm{h}$.

Toliau pristatomi skirtingu STV maksimalios generuojamos galios ir ištraukiamo oro srautų efektyvumų rezultatai. Šie rodikliai atitinkamai nustatomi lygtimis:

$$
\begin{gathered}
\eta_{E}=\frac{\dot{E}_{S T V}}{\dot{E}_{w}} ; \\
\eta_{Q}=\frac{\dot{Q}_{e}}{\dot{Q}_{w}},
\end{gathered}
$$


čia $\dot{E}_{w}-$ vejjo srauto galia tenkanti STV rotoriaus skerspjūvio plotui, W; $\dot{Q}_{w}-$ vèjo srautas tenkantis STV rotoriaus skerspjūvio plotui, $\mathrm{m}^{3} / \mathrm{h}$. Pastarieji rodikliai apskaičiuojami lygtimis:

$$
\begin{gathered}
\dot{E}_{w}=\frac{\rho \cdot u^{3} \cdot A_{v e}}{2} ; \\
\dot{Q}_{w}=u \cdot A_{v e} \cdot 3600 .
\end{gathered}
$$

2.17 paveiksle pateikiami minètujų efektyvumo rodiklių skaičiavimo rezultatai.

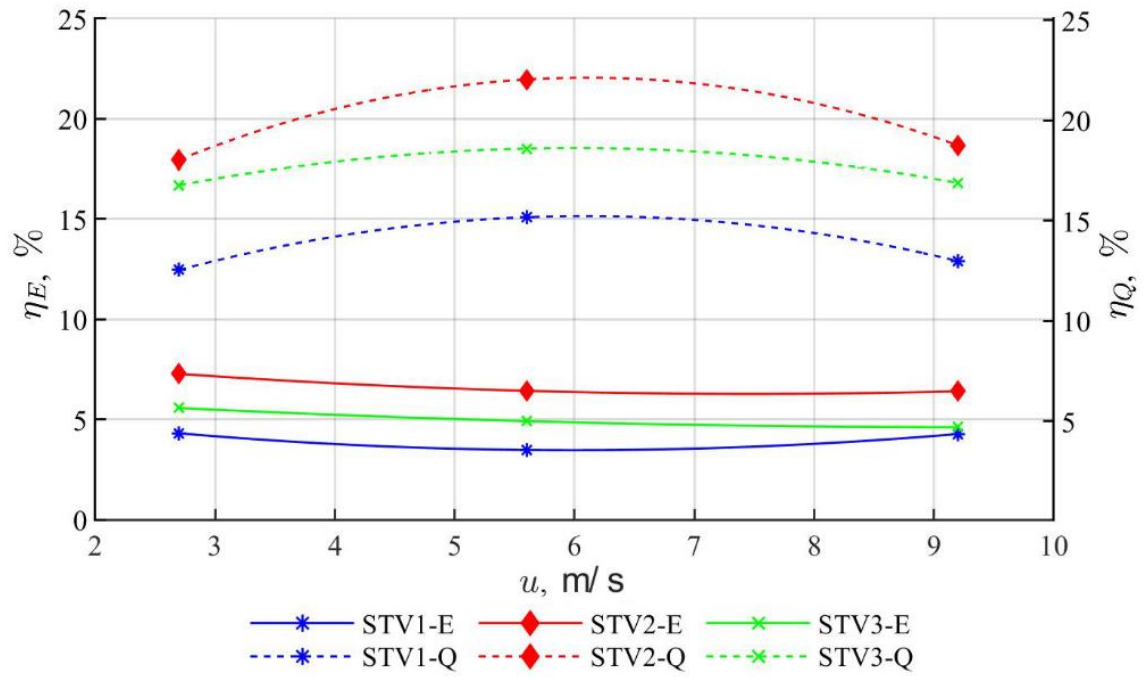

2.17 pav. Turbininių ventiliatorių maksimalios generuojamos galios ir ištraukiamo oro srautų efektyvumų palyginimas, esant skirtingiems vejjo greičiams

Fig. 2.17. Comparison of maximum generated power and extracted airflow efficiencies of turbine ventilators under variable wind speed

Šiame ir ankstesniame grafike pateikti generuojamų galių skaičiavimo rezultatai rodo, kad STV bandymų rezultatai panašūs ị "Savonius" tipo vejjo jègainių teorijoje pateikiamas teorines ribas (Twidell \& Weir, 2015). STV rotoriumi generuojama galia priklauso nuo rotoriaus dydžio bei apkrovos, o nuo vejjo greičio kinta kubine priklausomybe. Vertinant STV maksimalios generuojamos galios ir oro siurbimo efektyvumus nustatyta, kad tokių įrenginių generuojamos galios efektyvumas siekia nuo $4 \%$ iki $8 \%$, o siurbimo efektyvumas nuo $12 \%$ iki $22 \%$. Lyginant bandytu STV vejo energijos išnaudojimo efektyvumą, geriausias rezultatas pasiekiamas STV2 įrenginiu. 


\subsection{Antrojo skyriaus išvados}

Atlikus vejjo energiją naudojančių stoginių turbininių ventiliatorių eksperimentinius tyrimus nustatyta:

1. STV veiksmingumą labiausiai lemia vejjo greitis, statinio slègio vėdinamoje patalpoje ir aplinkoje skirtumas, aerodinaminès ịrenginių savybès. Pagal vejjo greičių ir statinio slègio skirtumų kitimą, geriausią ištraukiamo oro rezultatą pasiekia įrenginys su vertikaliai tiesiomis mentemis (STV2). Palyginimui pasirinkus atvirą ortakị, STV2 ištraukiamo oro srautas gali būti iki $8 \%$ didesnis. Priklausomai nuo sąlygų, visų kitų įrenginių ištraukiamo oro srauto veiksmingumas gali būti mažesnis iki $30 \%$. Tyrimų metu pastebèta, kad visi bandyti įrenginiai stipriai sumažina ịsiurbiamo vejjo srauto kiekị lyginant su atviru ortakiu. Šiuo atveju vertinant absoliučiuosius rodiklius iki $55 \%$ mažesnis įsiurbtas oro kiekis nustatytas įrenginyje su vertikalios ašies kryptimi lenktomis mentèmis (STV1).

2. Sukimo momento matavimo ir galių skaičiavimo rezultatai rodo, kad STV charakteristikos panašios ị teorines „Savonius“ tipo vejjo jègainių charakteristikas. STV rotoriumi generuojama galia priklauso nuo rotoriaus dydžio bei apkrovos, o nuo vejjo greičio kinta kubine priklausomybe. Nustatyta, kad apkrovus rotorių, maksimali STV generuojama galia pasiekiama rotoriaus sukimosi dažniui sumažejus pusiau.

3. Vertinant STV maksimalios generuojamos galios ir oro siurbimo efektyvumus nustatyta, kad tokių ịrenginių generuojamos galios efektyvumas siekia nuo $4 \%$ iki $8 \%$, o siurbimo efektyvumas nuo $12 \%$ iki $22 \%$. Lyginant bandytų STV vejjo energijos išnaudojimo efektyvumą, geriausias rezultatas pasiekiamas STV2 įrenginiu.

4. STV apytiksliai $50 \%$ ištraukiamo oro srauto pasiurbiama dèl ežekcijos reiškinio, o likusią 50 \% dali prideda STV rotoriaus sukimasis. Šiame darbe atlikti bandymai STV rotorių sukant papildomu energijos šaltiniu parodè, jog irenginị sukant vienodu dažniu be vejjo srauto, ištraukiamo oro debitas yra mažesnis apie $30 \%$ nei STV ịprasto veikimo metu.

5. Analizuojant aerodinaminio pasipriešinimo rodiklius nustatyta, kad STV1, $\mathrm{STV} 2, \mathrm{STV} 3 C_{d}$ rodikliai atitinkamai lygūs $1,8,1,02$ bei 1,45 . Kita vertus, sustabdžius STV rotorius, aerodinaminè trauka gali sumažèti iki 3 kartų. Bandymu metu pastebèta, kad STV veikimo metu susidaro išcentrinè jèga, padidinanti aerodinaminès traukos jègą. 


\section{Turbininio ventiliatoriaus trikomponentès koncepcijos termodinaminis modelis}

Šiame skyriuje pristatomas stoginio turbininio ventiliatoriaus termodinaminis modelis laikantis hipotezès, jog įrenginyje vykstantys procesai savyje apjungia procesus vejjo turbinose, ežektoriuose bei ventiliatoriuose. Šiuo pagrindu formuojama trikomponente koncepcija grindžiama sąsajomis su eksperimentinių tyrimų rezultatais. İrenginyje vykstantys srautiniai procesai nagrinejjami pagal ežektorių tyrimuose taikomą $h$-s diagramų analogiją.

Tokios koncepcijos pagrindu sukurtas modelis, taikant apibrěžtą skaičių eksperimentinių charakteristikų, leidžia kokybiškai ir kiekybiškai įvertinti STV veikimo metu sąveikaujančių srautinių procesų poveikị įrenginio funkcionalumui, nustatyti efektyvumą bei teorinị tobulinimo potencialą.

Pristatomame termodinaminiame modelyje apsiribojama procesais, kai vejjo ir siurbiamo oro srautai yra tokios pat sudèties, laikomi praktiškai nesuspaudžiamais (angl. subsonic flow), tekejjimo greičiai yra iki garsiniai (angl. subsonic) bei jiems taikomos idealiosioms dujoms būdingos savybès. Be to, fluidų tekèjimas priimamas vienmatis ir nekintantis laike.

Skyriaus tematika paskelbtos keturios publikacijos (Rimdžius et al., 2021; Martinaitis et al., 2020; Streckienè et al., 2021; Streckienė et al., 2018). 


\subsection{Turbininio ventiliatoriaus kontrolinis tūris}

STV termodinaminio modelio analizè pradedama nuo srautinių procesų masinių debitų bei būsenos parametrų ịvertinimo ties įrenginio kontroliniu tūriu. Aiškinant bendruosius veikimo principus bei išvedant skaičiavimams reikalingas lygtis naudojamos abstrahuotos schemos, kurios nesusietos su konkrečiu ịrenginiu. Siuo atveju įvertinus STV veikimo ypatybes bei oro srautų tekejjimo pobūdị - įrenginys analizuojamas kaip atvira termodinaminè sistema.

3.1 paveiksle vaizduojama STV principinè schema kartu su vėdinama patalpa. Schemoje pavaizduotas skerspjūvis $0-0$ rodo ištraukiamo oro įtekejjimo angą, skerspjūvis $1 *_{-} 1 *$ atitinka vejo srauto ir STV menčių sąveikos ribą, o skerspjūvis 6-6 vaizduoja susimaišiusių vejo ir ištraukiamo oro srautų ištekèjimą iš STV.

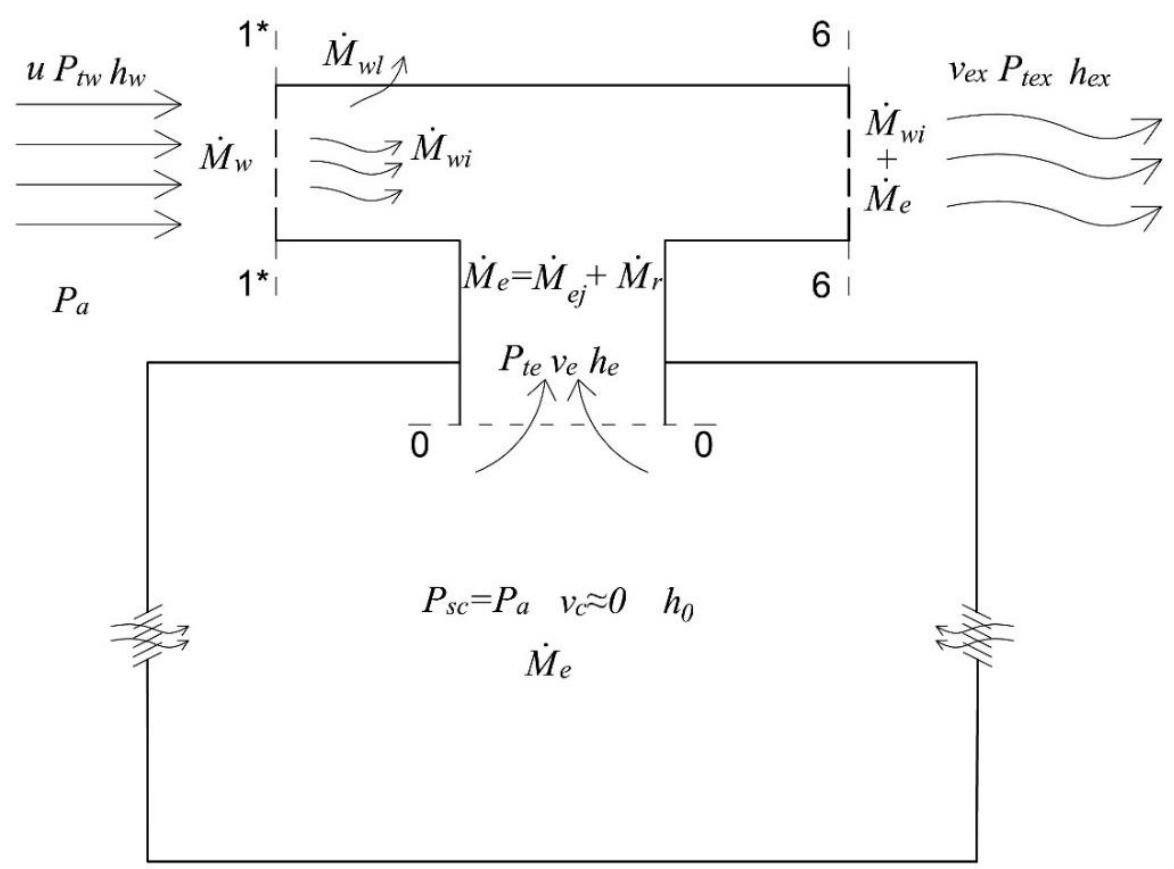

3.1 pav. Turbininio ventiliatoriaus kontrolinis tūris ir oro srautų būsenos parametrai

Fig. 3.1. Control volume of turbine ventilator and airflow state parameters

Remiantis 3.1 paveikslo schemoje pateiktomis kontrolinio tūrio ribomis matoma, kad ị termodinaminę sistemą ịeinantiems srautams priskiriamas vejjo srautas bei įrenginiu siurbiamas oras. Termodinaminiame modelyje priimama, jog STV mentes veikiantis vejo srautas atitinka ị $1 *-1 *$ skerspjūvị pučiamo oro debitą 
$\dot{M}_{w}=u \cdot A_{v e}$. Tuo tarpu, siurbiamo oro debitas $\dot{M}_{e}$ tiesiogiai priklauso nuo pučiamo vèjo greičio ir ịrenginio aerodinaminių savybių. Šiuo atveju iš patalpos ištraukiamo oro debitas nustatomas eksperimentiškai. Be to, atliekant šio tyrimo eksperimentus bei remiantis kitais tyrimais (Lai, 2003) vizualiai pastebèta, jog dalis ị STV rotorių pučiamo vèjo srauto atitrūksta. Todèl, vertinant kontrolinị tūrị paliekančius srautus, jiems priskiriamas atitrūkęs vėjo srautas $\dot{M}_{w l}$ bei STV rotoriaus vidumi pratekejusio vejjo srauto ir ištraukiamo iš patalpos oro srauto mišinys $\dot{M}_{w i}+\dot{M}_{e}$.

Ivertinus ịrenginio kontroliniame tūryje ịtekančius ir ištekančius oro srautus sudaroma apibendrinanti masès tolydumo lygtis:

$$
\dot{M}_{w}^{+}+\dot{M}_{e}^{+}=\dot{M}_{w l}^{-}+\dot{M}_{w i}^{-}+\dot{M}_{e}^{-} .
$$

Iprastai, analizuojant srautinius procesus vertinama jų vidinè energija (entalpija) bei srautų kinetiné ir gravitacinè potenciné energija. Pristatomame modelyje priimama prielaida, jog vejjo srautas iki sąveikos su STV teka neapribotame tūryje (atmosfera) bei nesusiduria su jokiomis tekejjimą veikiančiomis kliūtimis. Tai atitinka idealizuotas sąlygas, kurios sudaromos bandant ịrengini vejo tunelyje arba esant stabiliems atmosferos oro rodikliams. Ivertinus šią prielaidą priimama, kad iki priartejant prie STV rotoriaus, vejjo srauto statinis slègis lygus atmosferiniam slègiui $P_{s w}=P_{a}$. Be to, visų analizuojamą ịrenginị veikiančių oro srautų temperatūra yra vienoda visame tūryje. Todèl, atsižvelgiant ị šias sąlygas ir prielaidas, termodinaminiame modelyje nevertinama srautų gravitacinè potencinè energija.

Kita vertus, kaip jau buvo minèta, vienas pagrindinių veiksnių ịrenginio veikimui - pučiamo vèjo greitis $u$, dèl kurio judantis oras turi kinetinę energiją. Nagrinejjant srautinius procesus, pristatomame termodinaminiame modelyje patogu taikyti pilnosios entalpijos bei pilnutinio slègio būsenos parametrus, ịvertinančius srauto vidinę ir kinetinę energiją. Šiuo atveju vejjo srautui taikomos šios pilnosios entalpijos ir pilnutinio slègio skaičiavimo lygtys:

$$
\begin{gathered}
h_{w}=h_{a}+\frac{u^{2}}{2} ; \\
P_{t w}=P_{s w}+P_{d w}=P_{a}+\frac{\rho_{a} \cdot u^{2}}{2},
\end{gathered}
$$

čia $h_{w}, h_{a}$ - vejjo srauto pilnoji entalpija ir nejudančio atmosferos oro entalpija, $(\mathrm{J} / \mathrm{kg} \cdot \mathrm{K}) ; P_{t w}, P_{d w}-$ vejo srauto pilnutinis ir dinaminis slègis, $\mathrm{Pa}$. 
STV sąveikaujant su vėjo srautu, vyksta energijos transformavimo procesas, kurio metu atliekamas techninis darbas $\dot{E}_{S T V}$. Vèjo energijos atliekamas darbas naudojamas oro ištraukimui iš patalpos STV siurbimo kanalu (skerspjūvis 0-0). Termodinaminiame modelyje priimama, jog statinis slègis vėdinamoje patalpoje lygus atmosferiniam slėgiui $P_{s c}=P_{a}$, o išsiurbto oro pritekėjimas netrukdomai vyksta pro patalpos angas. Be to, vėdinamos patalpos tūris yra didelis, todèl ištraukiamas oro srautas šioje erdvèje juda labai lètai ir priimama prielaida, jog oro judejjimo greitis šioje patalpoje $v_{c} \approx 0$. İvertinus šias prielaidas priimama, kad patalpoje esančio oro pilnoji entalpija atitinka nejudančio atmosferos oro entalpiją $h_{0}=h_{a}$.

Orui tekant STV vidumi jis susiduria su aerodinaminėmis kliūtimis, vyksta trintis tarp oro ir įrenginio paviršiaus, todèl susidaro srauto slègio nuostoliai. Šiuo atveju dèl trinties susidariusi disipacija modelyje vertinama energijos virtimu i šilumą $\dot{Q}_{S T V}$, kuri palieka termodinaminę sistemą. Atsižvelgiant i tai, kad srautiniai procesai modelyje laikomi nekintančiais laike bei įvertinus atliekamą darbą ir susidarančius nuostolius - nagrinèjamai atvirai termodinaminei sistemai, pagal pirmajị termodinamikos dèsnị sudaroma tokia energijos balanso lygtis:

$$
\dot{M}_{w}^{+} h_{w}+\dot{M}_{e}^{+} h_{0}=\dot{M}_{w l}^{-} h_{1}+\left(\dot{M}_{w i}^{-}+\dot{M}_{e}^{-}\right) h_{e x}+\dot{E}_{S T V}+\dot{Q}_{S T V} \text {. }
$$

Šioje lygtyje anksčiau nepaaiškinti dydžiai $h_{l}$ ir $h_{e x}$ atitinkamai žymi ị STV kontrolinị tūrị ịtekančio vèjo srauto entalpiją bei ịrenginị paliekančio oro srauto mišinio entalpiją.

\subsection{Turbininio ventiliatoriaus menami komponentai}

Toliau detaliau aptarkime STV vykstančius procesus. Vertinant įrenginio veikimo principą bei remiantis eksperimentiniais tyrimais - pastebimas STV konstrukcinis panašumas ị kitus įrenginius ir juos siejantis struktūrinis ir sąveikinis ryšys. Norint geriau suprasti ịrenginio veikimo ypatybes, 3.2 paveiksle pateikiami įrenginio skerspjūviai iš viršaus, kuriuose dekomponuojami atskiri menami STV komponentai. Irenginyje sąveikaujančių oro srautų procesai vaizduojami STV suskaidant ị menamus turbinos, ežektoriaus ir ventiliatoriaus komponentus. 


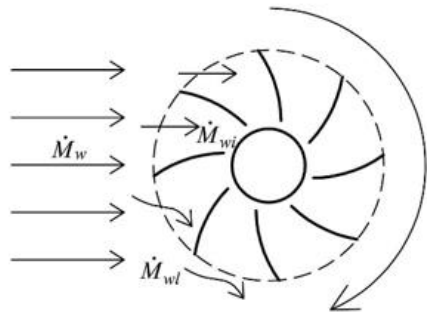

a)

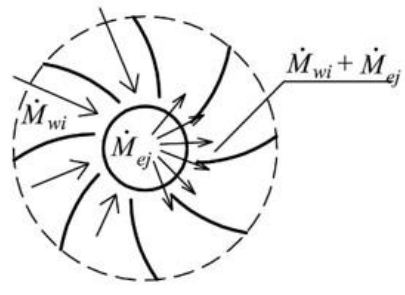

b)

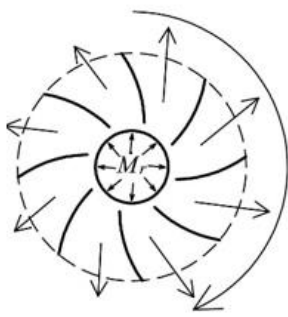

c)

3.2 pav. Turbininio ventiliatoriaus struktūrinis suskirstymas į menamus komponentus: a) turbina; b) ežektorius; c) ventiliatorius

Fig. 3.2. The turbine ventilator structural breakdown into hypothetical components:

a) turbine; b) ejector, c) ventilator

Tolesniuose poskyriuose detaliau aptariamos šių komponentų ypatybès ir sąveikos ryšiai STV veikimo metu.

\subsubsection{Turbinos termodinaminis modelis}

Analizuojant vejjo srauto ir STV sąveiką pagal 3.2 paveiksle (a) pateiktą irenginio schemą, visų pirma pastebimas panašumas ị vejjo jègainę (turbiną). Šị panašumą galima sieti ir su tuo, jog $1932 \mathrm{~m}$. Savonius atliko tyrimą su jo paties išrastu „S-rotoriaus“ tipo vejo energija varomu ventiliatoriumi (Savonius, 1932). Šiuo atveju, skerspjūvyje vertinant ịrenginio menčių geometriją bei išdėstymą, akivaizdu, kad įrenginio rotoriaus kairè pusè yra sukama vejo srauto, todèl vertinant STV rotoriaus konstrukciją ir veikimo principą, ji priimama laikyti panašiu ị „Savonius“ tipo vejjo jègainę (3.3 pav.).

Remiantis šiuo įrenginių konstrukciniu panašumu, pristatomame termodinaminiame modelyje taikomi kai kurie vejjo jëgainių galios skaičiavimo metodikos principai. Ivvertinus STV rotoriaus skerspjūvio plotą statmeną vèjo srauto tekejjimo krypčiai $\left(1^{*}-1 *\right.$ skerspjūvis), apskaičiuota teorinè (potenciali) vejjo srauto galia tenkanti STV nustatoma 2.22 lygtimi.

Detaliau analizuojant ịrenginio konstrukcines ir aerodinamines savybes pastebima, kad STV rotorių galima padalinti ị dvi menamas dalis. Pagal menčių geometriją, jų padètį vèjo krypties atžvilgiu bei „Savonius“ tipo vejjo jègainèms būdingas ypatybes, įrenginio mentès suskirstomos ị varomąsias bei grižtančiąsias mentes (Sun et al., 2012). 


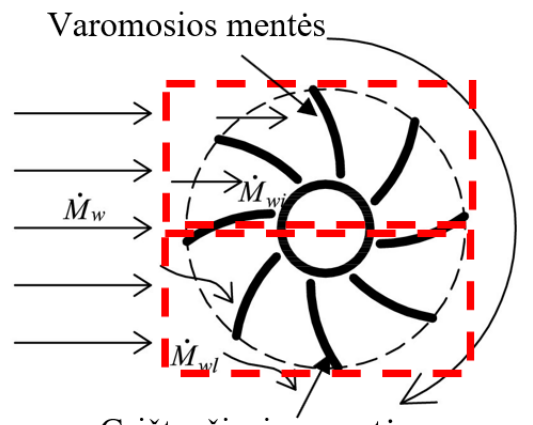

Grịžtančiosios mentès

a)

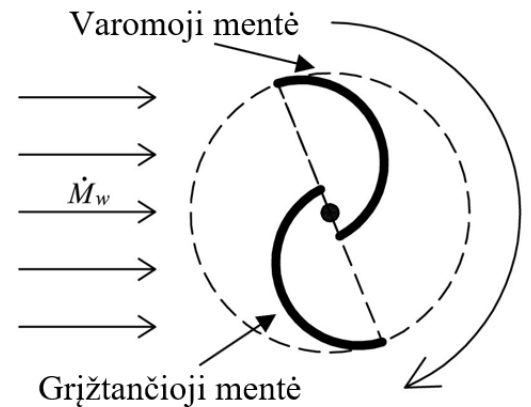

b)

3.3 pav. Turbininio ventiliatoriaus rotoriaus veikimo schema ir panašumas i „,Savonius“ vèjo jègainę: a) turbininio ventiliatoriaus rotorius; b) „Savonius“ vėjo jègainès rotorius Fig. 3.3. Operation scheme of turbine ventilator's rotor and similarity to Savonius wind turbine: a) rotor of turbine ventilator; b) rotor of Savonius wind turbine

Šiuo atveju viršutinèje 3.3 paveikslo (a) dalyje parodytos mentès yra varomosios, o žemiau esančios mentès - grižtančiosios. Varomosios STV rotoriaus mentès sąveikaujančios su vejjo srautu, atlieka „Savonius“ tipo vèjo jègainèms būdingą sukimo darbą $\dot{E}_{t}$. Šioje dalyje atidirbęs vejjo srautas $\dot{M}_{w i}$ toliau prateka i rotoriaus vidų ir dalyvauja kituose procesuose. Tuo tarpu, grịžtamosios STV mentės atlieka priešingą efektą. Sąveikaudamos su vėjo srautu, jos stabdo STV rotoriaus sukimąsi. Be to, jų geometrinès savybės, dalị į STV rotorių pučiamo vejjo srauto $\dot{M}_{w l}$ nukreipia nuo savęs - t. y. ịvyksta oro srauto aptekejjimas ir atsiskyrimas (angl. wake) nuo STV rotoriaus. Dèl to, šioje zonoje i STV vidų patenka daug mažesnis vejjo srautas.

Eksperimentiškai nustatyti atitrūkusio vèjo srauto dalị sudètinga dèl sunkiai išmatuojamo oro srauto aplink STV. Pastarasis dydis priklauso nuo įrenginio geometrinių savybių, vejjo greičio bei rotoriaus sukimosi dažnio. Šiuo atveju neturint galimybių tiksliai nustatyti atitrūkusio srauto dalies, šis srautas vertinamas pastoviu dydžiu, priklausančiu nuo vejjo greičio ir nuo irenginio geometrijos. Pateiktame termodinaminiame modelyje, šiam srautui nustatyti taikomas atitrūkusio srauto dalies koeficientas $k_{w l}$. Remiantis šiuo koeficientu, nuo menčių atitrūkęs srautas apskaičiuojamas šia lygtimi:

$$
\dot{M}_{w l}=k_{w l} \cdot \dot{M}_{w} .
$$

Toliau detaliau aptarkime STV menamos turbinos dalyje vykstančius termodinaminius procesus vejjo tekejjimo kryptimi. Šiuo atveju siekiant geriau 
suprasti menamų komponentų poveiki įrenginio veikimui, 3.4 paveiksle pasirenkama STV vaizdavimo iš šono schema. 3.4 paveiksle pateiktos įrenginio schemos kairioji pusé, apribota skerspjūviais $1 *-1 *$ ir $1-1$, vaizduoja menamos turbinos dali. Termodinaminiame modelyje priimama, jog vèjo srauto pilnoji entalpija ties turbinos paviršiumi (skerspjūvyje $1{ }^{*}-1 *$ ) atitinka pilnają vejjo entalpiją $h_{1^{*}}=h_{w}$. Vejjui sukant STV turbinos mentes atliekamas darbas $\dot{E}_{t}=\dot{M}_{w} \cdot\left(h_{1^{*}}-h_{1}\right)$, todèl pratekèjus mentes mažeja vèjo srauto greitis bei tuo pačiu pilnoji entalpija ir pilnutinis slègis.

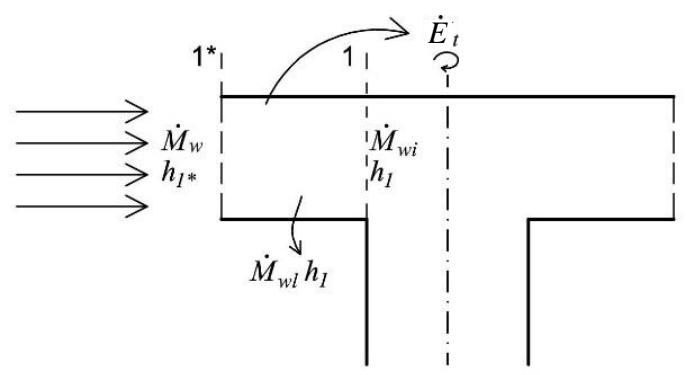

3.4 pav. Turbininio ventiliatoriaus turbinos dalyje vykstantys termodinaminiai procesai

Fig. 3.4. Thermodynamic processes in the turbine part of a turbine ventilator

Pateiktos pirmojo termodinamikos dèsnio lygtys ịvertina būsenos parametrus kontrolinio tūrio ịèjime ir išèjime, tačiau neatsižvelgia ị termodinaminès sistemos viduje vykstančius procesus. Energijos transformavimo metu, įrenginyje vyksta trinties ir disipacijos reiškiniai, kuriems ịvertinti taikomas antrasis termodinamikos dèsnis. Siekiant akivaizdžiau parodyti sistemos viduje vykstančius procesus, negrịžtamumo reiškiniai pagal ATD ịvertinami naudojant entropijos būsenos parametrus. Šiuo atveju analizuojant proceso negrịžtamumą modelyje skaičiuojamas entropijos pokytis nuo proceso pradžios iki pabaigos. Laikant oro srautą idealiomis dujomis, bendru atveju entropijos pokytis skaičiuojamas pagal šią lygtị:

$$
s\left(T_{2}, P_{2}\right)-s\left(T_{1}, P_{1}\right)=\int_{T_{1}}^{T_{2}} c_{p}(T) \frac{d T}{T}-R \ln \frac{P_{2}}{P_{1}},
$$

čia $T$ - absoliutinė temperatūra, $\mathrm{K} ; P$ - absoliutinis slègis, Pa; $c_{p}$ - oro savitoji šiluma, $\mathrm{J} /(\mathrm{kgK}) ; R$ - universalioji dujų konstanta; 1,2 - indeksai atitinkamai žymintys termodinaminio proceso pradžią ir pabaigą. 
STV veikimo metu, oro srautų slègiai labai artimi atmosferiniam slègiui, todèl modelyje priimama $c_{p}=$ const. Be to, ìvertinus tai kad idealioms dujoms galioja temperatūros ir entalpijos ryšys $h=T \cdot c_{p}$, galima taikyti šią entropijos pokyčio skaičiavimo lygtį:

$$
\Delta s=c_{p} \cdot \ln \left(\frac{h_{2}}{h_{1}}\right)-\ln \left(\frac{P_{2}}{P_{1}}\right) \cdot R .
$$

Srautų trintis ir ne idealiai atliekamas darbas lemia tai, kad STV vykstantys procesai yra ne izoentropiniai, todèl pagal išskirtus menamus komponentus, modelyje taikomi jiems būdingi izoentropinio efektyvumo koeficientai $\eta$. Tokių koeficientų naudojimas plačiai taikomas nagrinëjant ežektorių termodinaminius modelius. Šiuo atveju procesų komponentuose sukeliami negrižtamumai ịvertinami eksperimentinių tyrimų rezultatais arba pagal mokslinejje literatūroje nurodytus duomenis panašios konstrukcijos įrenginiams. Visais atvejais, žymejjimai su indeksu ' modelyje rodo idealų grižtamaji procesą, kuomet $\Delta s=0$. Analizuojant STV turbinoje vykstančius procesus, galima sudaryti tokią procesų grịžtamumą ịvertinančią išraišką:

$$
\eta_{t}=\frac{\left(h_{1^{*}}-h_{1}\right)}{\left(h_{1^{*}}-h_{1}^{\prime}\right)} .
$$

Fizikine prasme ši išraiška reiškia, jog STV turbinai veikiant idealiai ir vėjo srauto pilnutiniam slègiui sumažejus iki realaus proceso metu pasiekiamo slègio $P_{1}$ - būtų galima gauti galią $\ddot{E}_{t}^{\prime}=\dot{M}_{w} \cdot\left(h_{1^{*}}-h_{1}^{\prime}\right)$, kuri būtų didesnè nei realaus veikimo atveju $\left(\dot{E}_{t}^{\prime}>\dot{E}_{t}\right)$.

Išmatavus turbinoje generuojamą galią bei žinant joms būdingą izoentropinị naudingumo koeficientą, pagal 3.8 lygti nesunkiai apskaičiuojama idealaus veikimo teorinè galia ir vejjo srauto entalpija tokio proceso pabaigoje. Eksperimentinių tyrimų metu nustatyti atidirbusio vèjo srauto slègị STV viduje sudètinga. Tačiau ịvertinus tai, kad idealaus proceso metu $\Delta s=0$, pagal 3.9 lygtị galima apskaičiuoti vèjo srauto slègi po turbinoje atlikto darbo:

$$
P_{1}=P_{1^{*}} \cdot e^{\frac{c_{p} \cdot \ln \left(\frac{h_{1}^{\prime}}{h_{1 *}}\right)}{R}} .
$$

Kaip jau buvo minèta anksčiau, srautinių tekejjimo procesų analizei paranku naudoti entalpijos-entropijos diagramas, todèl 3.5 paveiksle pateikiama termodinamini procesą STV turbinoje vaizduojanti diagrama. 


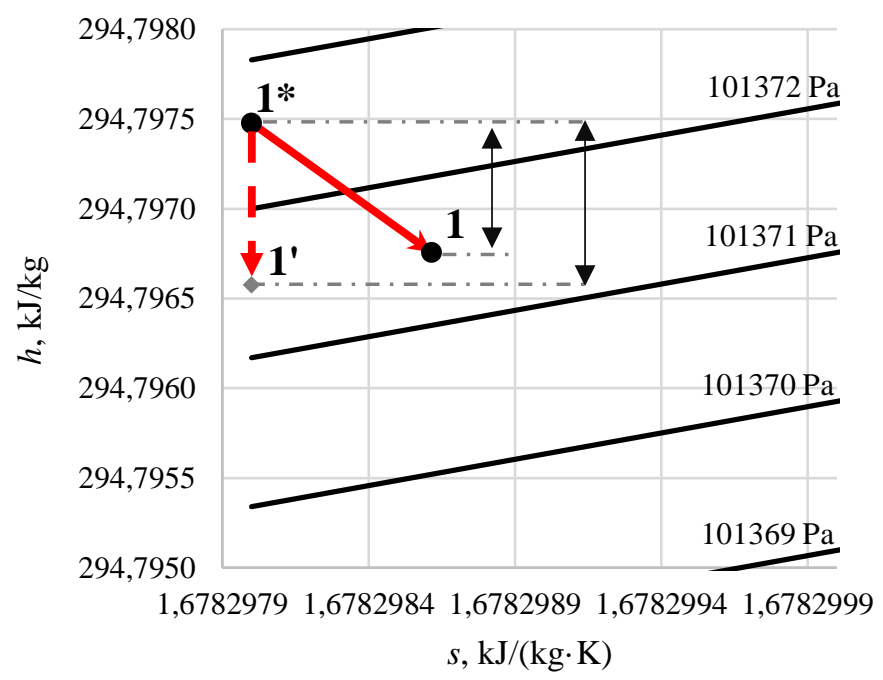

3.5 pav. $h$-s diagrama vaizduojanti turbininio ventiliatoriaus turbinos dalyje vykstančius termodinaminius procesus

Fig. 3.5. $h$-s diagram of thermodynamic processes in the turbine part of a turbine ventilator

Paveiksle pavaizduotas taškas $1^{*}$ atitinka pradinius vejjo srauto būsenos parametrus. Taškas 1' atitinka vèjo srauto būsenos parametrų vertes esant idealiam grịžtamajam procesui. Raudona tiese jungianti $1 *$ ir 1 taškus vaizduoja realų procesą STV turbinoje. Tuo tarpu, raudona punktyriné tiesé jungianti $1 *$ ir 1' taškus rodo idealų grižtamaji procesą. Skaitiniai STV procesų rodikliai detalizuojame toliau esančiuose skyriuose.

\subsubsection{Ežektorius termodinaminis modelis}

Toliau aptarkime kituose įrenginiuose vykstančius procesus. Pagal STV viduje vykstančių procesų sąveiką toliau galima išskirti menamus ežektoriaus ir ventiliatoriaus komponentus. Tačiau prieš pradedant šių komponentų analizę, detaliau ịvertinkime reiškinius, kurie vyksta STV oro siurbimo kanale.

Siurbimo metu, patalpoje esančiam srautui lètai judant (dèl didelio patalpos tūrio) ị oro ištraukimo kanalą, keičiasi tekejjimo skerspjūvio plotas, todèl šis siurbiamas oro srautas kanale pagreitëja iki greičio $v_{e}$. Priklausomai nuo siurbiamo oro srauto tekejjimo greičio, idealiu atveju siurbimo kanale esančio oro srauto pilnoji entalpija ir dinaminis slègis nustatomas šiomis lygtimis: 


$$
\begin{aligned}
& h_{e}^{\prime}=h_{0}+\frac{v_{e}^{2}}{2} ; \\
& P_{d e}^{\prime}=\frac{\rho \cdot v_{e}^{2}}{2} .
\end{aligned}
$$

Idealiu atveju pilnutinis siurbiamo oro srauto slègis priklausytų tik nuo dinaminio slėgio pokyčio. Tačiau ịrenginiui veikiant realiomis sąlygomis, ruože nuo siurbimo kanalo ittekejjimo angos iki ištekejjimo yra aerodinaminis pasipriešinimas. Šis reiškinys vertinamas kaip disipacija ir gali būti įvertintas kiekybiškai. İvertinus aerodinaminio pasipriešinimo nuostolius, pilnutinis siurbiamo oro srauto slègis bei pilnoji entalpija reikiamam srautui pasiekti atitinkamai lygūs:

$$
\begin{gathered}
P_{t e}=P_{a}+\zeta \cdot P_{d e}=P_{a}+\zeta \cdot \frac{\rho \cdot v_{e}^{2}}{2} ; \\
h_{e}=h_{0}+\zeta \cdot \frac{v_{e}^{2}}{2} .
\end{gathered}
$$

Vertinant STV konstrukciją bei veikimo principą oro siurbimo metu, šiame darbe pristatytų eksperimentinių rezultatų dalyje nustatyta, jog įrenginys pasižymi ežektoriaus (3.2 pav. b) ir išcentrinio ventiliatoriaus (3.2 pav. c) savybėmis.

Ežektorius, veikimo prasme dažnai suprantamas kaip įrenginys, kuriame aukšto slègio fluidas (įvardinamas kaip aktyvus srautas) naudojamas pasiurbti žemesnio slėgio fluidą (ivardinamas kaip pasyvus srautas). Dèl šlyties jègų tarp judančio fluido ir aplinkinio nejudančio fluido, dalis aktyvaus fluido kinetinès energijos yra perduodama nejudančiam (pasyviam) fluidui, tokiu būdu sukuriant ežekcijos efektą. Nagrinejjamo įrenginio atveju tai atitinka ị rotoriaus vidų patekusį vejjo srautą, kuris dèl savo tekèjimo greičio virš STV siurbimo kanalo sukuria žemo slègio zoną ir iš jo pasiurbia patalpos orą.

Toliau esančiame 3.6 paveiksle pateikiama principinè schema rodanti STV panašumą i ežektorių. Šio paveikslo dešinèje pusèje parodyta ežektoriaus schema, kurios pagrindiniai komponentai yra tūta, sumaišymo kamera ir difuzorius. Remiantis šia analogija, tūtą atitinka STV rotoriaus kairioji pusè, nuo 1-1 iki 2-2 skerspjūvių, maišymosi daliai priskiriama centrinè zona, apribota $2-2,3-3$ bei 4-4 skerspjūviais, o difuzorius atitinka dešiniąją STV rotoriaus dali nuo 4-4 iki 6-6 skerspjūvių.

Pagal siurbiamų srautų prigimtį, ežekcijos ir STV rotoriaus procesų sąveika panaši ì lygiagrečiai sujungtų ventiliatorių veikimą. Anksčiau pristatomuose eksperimentiniuose tyrimuose nustatyta, kad STV apytiksliai pusę ištraukiamo 
oro srauto pasiurbia dèl ežekcijos reiškinio $\left(\dot{M}_{e j}\right)$, o likusią dalị prideda STV rotoriaus sukimasis $\left(\dot{M}_{r}\right)$.

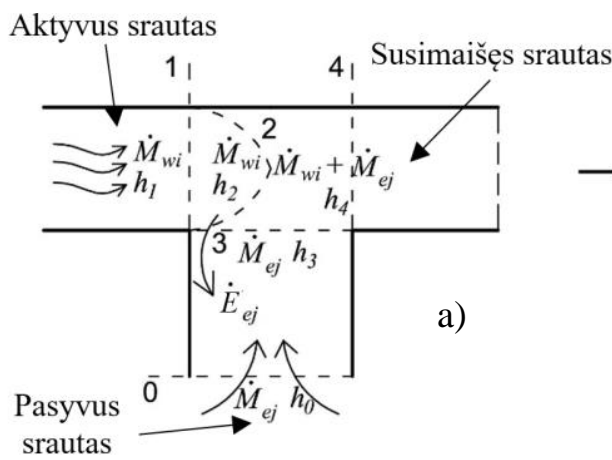

Susimaišęs srautas

3.6 pav. Turbininio ventiliatoriaus termodinaminių srautų schema ir veikimo principo panašumas ị ežektorių: a) turbininio ventiliatoriaus schema; b) ežektoriaus schema

Fig. 3.6. The scheme of thermodynamic flows of a turbine ventilator and similarity to ejector: a) scheme of turbine ventilator; b) scheme of ejector

Šiuo atveju atsižvelgiant ị tokị oro srautų pasiskirstymą, modelyje ịvedamas ežektuojamo oro srauto koeficientas $k_{e j}$, kuris priklauso tik nuo STV konstrukcinių ypatumų ir yra nustatomas eksperimentiškai. Kiekybiškai ịvertinus ežektuojamo ir STV rotoriumi pasiurbiamų srautu pasiskirstymą, ežekcijos metu siurbiamo oro srauto vidutinis greitis įtekèjimo kanale nustatomas pagal šią lygtị:

$$
v_{e j}=k_{e j} \cdot v_{e} .
$$

Siurbiamam oro greičiui pasiekti reikalingas pilnutinio slègio pokytis, remiantis 3.12 lygtimi:

$$
\Delta P_{t e j}=\zeta \cdot \frac{\rho \cdot v_{e j}^{2}}{2} .
$$

Toliau detaliau aptarkime STV ežektoriaus dalyje vykstančius termodinaminius procesus vejjo tekejjimo kryptimi. Šiame modelio priimama, jog vejo srauto pilnoji entalpija ties ežektoriaus zona (skerspjūvis 1-1), atitinka pilnąją vejjo srauto entalpiją po atlikto darbo turbinoje $h_{l}$. Vèjo srautas esantis STV rotoriaus viduje pasiurbdamas patalpos orą ežekcijos metu atlieka darbą:

$$
\dot{E}_{e j}=\dot{M}_{w i} \cdot\left(h_{1}-h_{2}\right) \text {. }
$$


Analogiškai turbinos veikimui, ežekcijos proceso metu vyksta oro srautų trintis, todèl šis procesas yra negrižtamasis. Šiuo atveju modelyje taikomas izoentropinio efektyvumo koeficientas, kuris parenkamas atsižvelgiant i mokslinėje literatūroje nurodytus duomenis panašios konstrukcijos ežektoriams. Analizuojant STV ežektoriuje vykstančius procesus, sudaroma tokia procesų grịžtamumą ịvertinanti lygybè:

$$
\eta_{e j}=\frac{\left(h_{1}-h_{2}\right)}{\left(h_{1}-h_{2}^{\prime}\right)} .
$$

Toliau esančiame 3.7 paveiksle pateikiama termodinaminị ežekcijos procesą vaizduojanti entalpijos-entropijos diagrama.

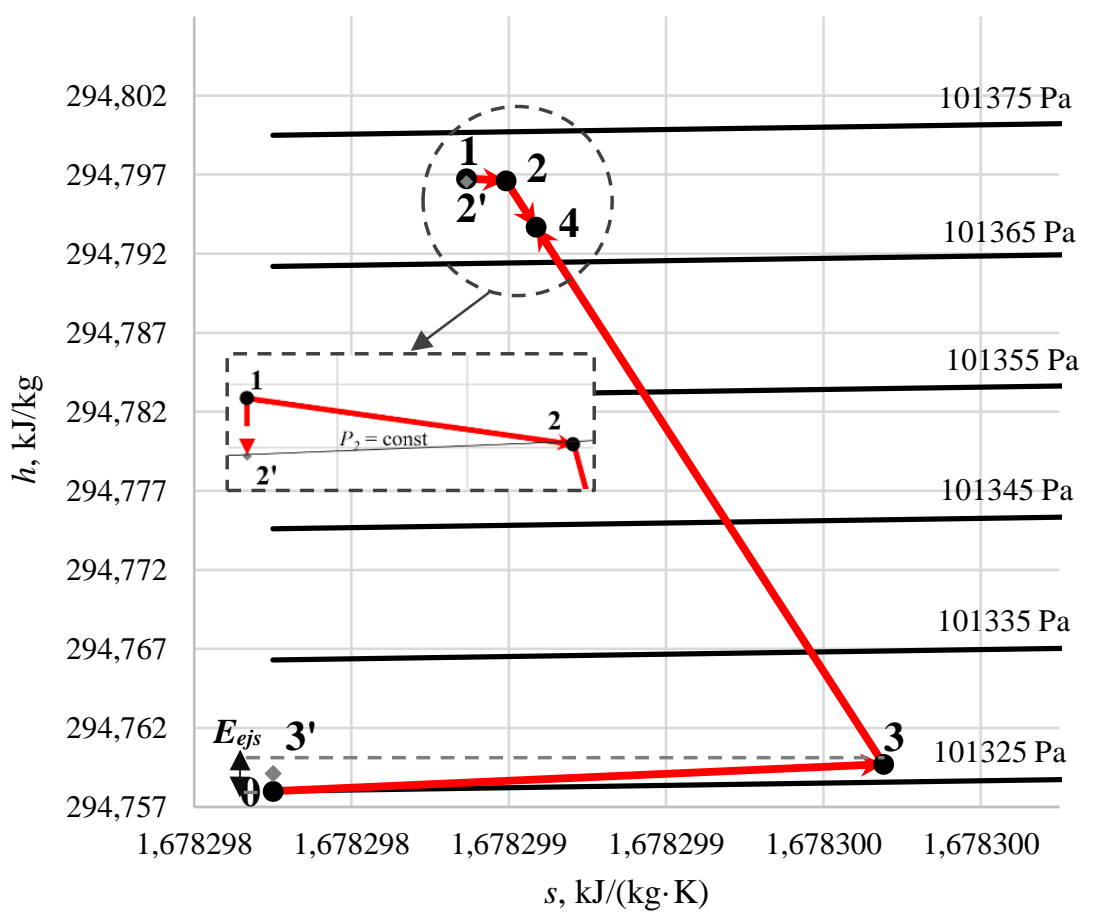

3.7 pav. $h$-s diagrama vaizduojanti turbininio ventiliatoriaus ežektoriaus dalyje vykstančius termodinaminius procesus

Fig. 3.7. $h$-s diagram of thermodynamic processes in the ejector part of a turbine ventilator 
Diagramoje pavaizduotas taškas 1 atitinka vèjo srauto pilnosios entalpijos vertę prieš ežekciją, taškas 2 rodo vèjo srauto būsenos parametrus po ežekcijos proceso metu perduotos energijos, o taškas $2^{\prime}$ vaizduoja vejo srauto būsenos parametrus esant idealiam grižtamajam procesui. Pradiniai patalpos oro būsenos parametrai prieš siurbimą pavaizduoti tašku 0 . Siekiant detalizuoti procesus, toliau pateiktas papildomas 3.8 paveikslas, kuriame vaizduojama tik aktyvaus vèjo srauto procesų seka.

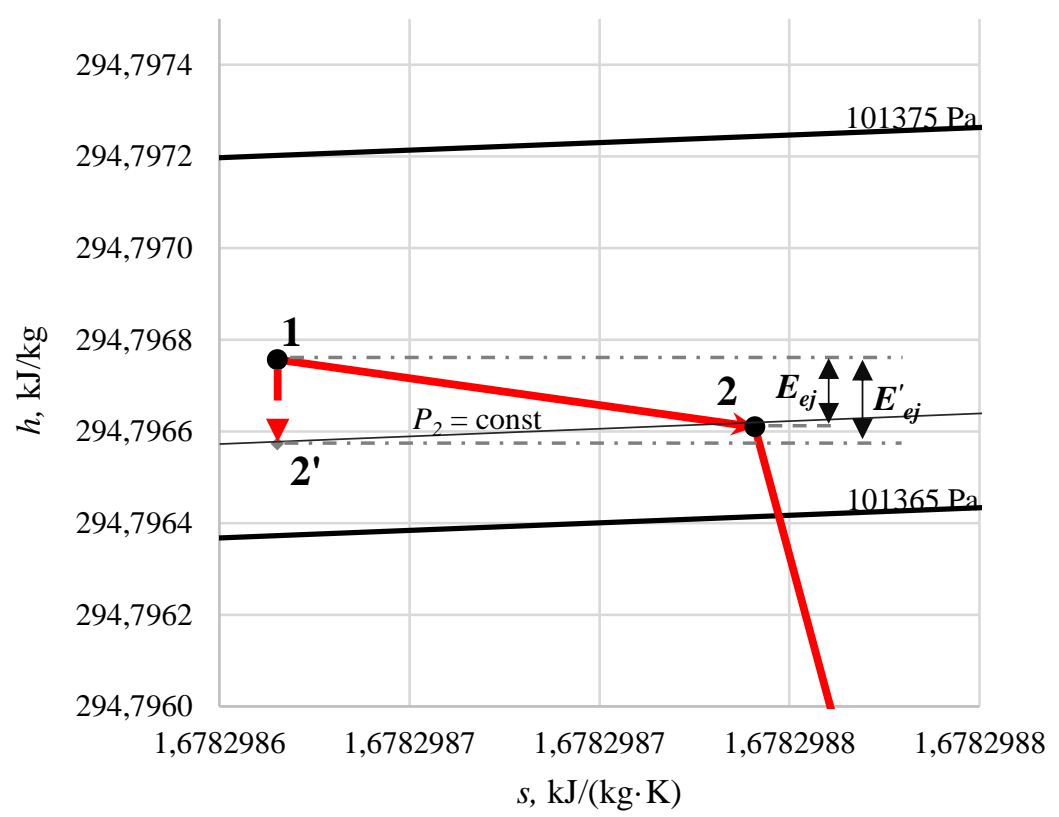

3.8 pav. Ežektoriaus $h$-s diagramos detalizacija

Fig. 3.8. Detailing of ejector's $h-s$ diagram

Čia atkreipiamas dèmesys, jog visose pristatomo termodinaminio modelio diagramose vaizduojami procesai pateikti proporcingai atsižvelgiant i STV siurbiamo oro debitą. Kadangi vejjo ir siurbiamo oro srautų debitai nevienodi - šie rezultatai kiekvieno ịrenginio atveju skiriasi.

Remiantis pateiktais grafikais matoma, jog ežekcijos metu, aktyvaus vejjo srauto suteikta energija $\dot{E}_{e j}$ pasyviam patalpos oro srautui vaizduojama procesu 0-3. Modelyje, taip pat taikomas izoentropinis srauto suspaudimo koeficientas $\eta_{e j s}$, kurio skaitinè verte atvirkščiai proporcinga STV aerodinaminio pasipriešinimo koeficientui. Šiuo atveju esant idealiam oro suspaudimui (oro 
siurbimo metu), reikiamam oro debitui palaikyti pakaktų tik dinaminio slègio pokyčio $\Delta P_{d e j}$, tačiau realaus proceso metu, dèl STV susidarančių slègio nuostolių, reikia užtikrinti slègi $\Delta P_{t e j}$. Todèl, izoentropinis oro siurbimo koeficientas atitinkamai lygus:

$$
\eta_{e j s}=\frac{\Delta P_{d e j}}{\Delta P_{t e j}}=\frac{\Delta P_{d e j}}{\zeta \cdot \Delta P_{d e j}}=\frac{1}{\zeta} .
$$

3.7 paveikslo diagramoje pavaizduotas taškai 3' ir 3 atitinka oro siurbimui reikalingo dinaminio slègio pokytị $\Delta P_{d e j}$, tačiau dèl susidarančių slėgio nuostolių, pasislinkęs ị dešinę pusę taškas 3 rodo entropijos priaugị bei didesnę reikiamą pilnąją entalpiją. Atitinkamai, izoentropinị oro siurbimo koeficientą galima užrašyti šia lygtimi:

$$
\eta_{e j s}=\frac{\left(h_{3}^{\prime}-h_{0}\right)}{\left(h_{3}-h_{0}\right)} .
$$

Fizikine prasme ši išraiška reiškia, jog ežekcijos metu idealiai siurbiant patalpos oro srautą, tam pačiam oro kiekiui ištraukti užtektų mažesnio energijos kiekio, todèl galioja sąlyga $\dot{E}_{e j s}>\dot{E}_{e j s}^{\prime}$. Ivvertinus ežekcijos proceso metu aktyvaus vejjo srauto suteiktą galią, modelyje galioja lygybè:

$$
\dot{E}_{e j s}=\dot{E}_{e j}=\dot{M}_{e j} \cdot\left(h_{3}-h_{0}\right) .
$$

Darbe atliktų eksperimentinių tyrimų metu nustatyta, kad vejjo ir siurbiamo srauto masinių debitų santykis yra didesnis nuo 4 iki 6 kartų. Dẻl šios priežasties, vaizduojant aktyvaus vejjo srauto ir ežektuojamo patalpos oro srauto entalpijos pokyčius, galima pastebėti atitinkamus galutinių entalpijos verčių pokyčius. Visais atvejais, diagramose pastebimas mažesnis vejo srauto entalpijos pokytis lyginant su pasiurbto oro entalpijos pokyčiu.

Ežekcijos metu, STV siurbimo kanalu tekantis oro srautas toliau patenka i 2-2, 3-3 bei 4-4 skerspjūviais apribotą rotoriaus dalị. Šioje ịrenginio dalyje vyksta skirtingų būsenos parametrų, vèjo ir siurbiamo oro fluidų maišymasis. Ivertinus masinių debitų skirtumus bei šių srautų entalpijos vertes, 3.7 paveikslo diagramoje šis maišymosi procesas vaizduojamas galutiniu tašku 4 , bei proceso kryptị rodančiomis tiesèmis 2-4 ir 3-4. Proceso galutiniai entalpijos ir entropijos būsenų parametrai, pagal proporcijas atitinkamai apskaičiuojami šiomis lygtimis:

$$
h_{4}=\frac{\dot{M}_{w i} h_{2}+\dot{M}_{e j} h_{3}}{\dot{M}_{w i}+\dot{M}_{e j}} ;
$$




$$
s_{4}=\frac{\dot{M}_{w i} s_{2}+\dot{M}_{e j} s_{3}}{\dot{M}_{w i}+\dot{M}_{e j}} .
$$

Šie maišymosi proceso būsenos parametrai toliau naudojami nagrinèjant kitus STV vykstančius procesus.

\subsubsection{Ventiliatorius termodinaminis modelis}

Kaip jau buvo minèta, eksperimentiškai nustatyta, jog STV oro siurbimas priklauso nuo ežektoriams ir ventiliatoriams būdingų procesų. Vertinant pastarojo veikimo ypatybes, STV turi esminių konstrukcinių panašumų i rinkoje egzistuojančius stoginius elektra varomus ventiliatorius. Veikimo prasme, tokie ịrenginiai panašŭs i išcentrinius ventiliatorius be mentes dengiančio išorinio korpuso, todèl ištraukiamas oras ị aplinką išteka tarp menčių esančiais tarpais. Toliau esančiame 3.9 paveiksle pateikiama principinè schema rodanti STV panašumą ị stoginị ventiliatorių.
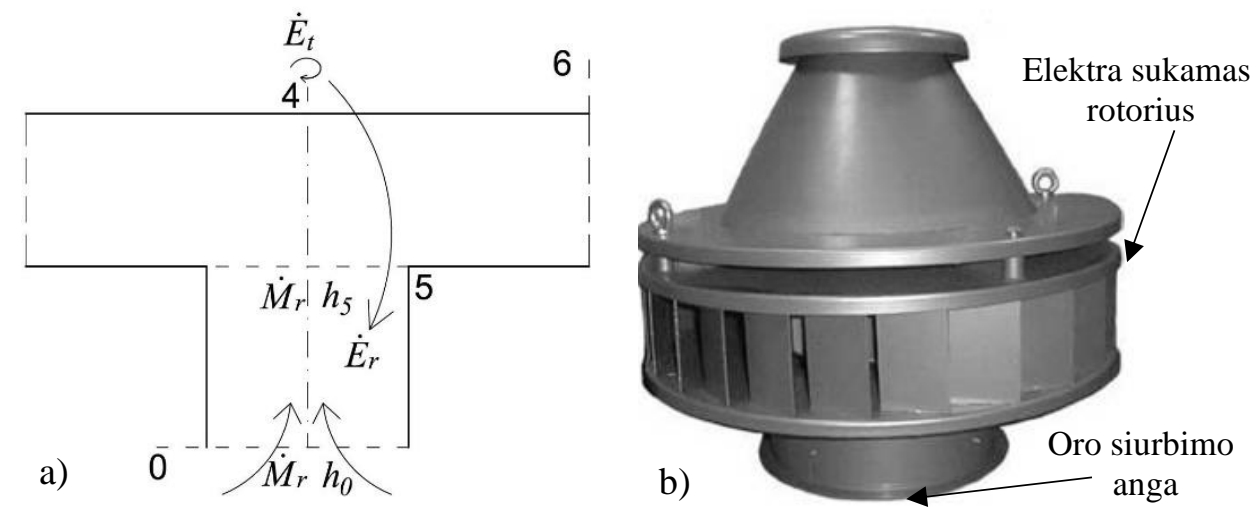

3.9 pav. Menamo ventiliatoriaus komponento termodinaminių srautų schema bei panašumas ị elektrinị stoginị ventiliatorių: a) menamo ventiliatoriaus schema;

b) elektrinio stoginio ventiliatoriaus nuotrauka

Fig. 3.9. Thermodynamic flows scheme of the hypothetical ventilator and its similarity to an electric rooftop ventilator: a) scheme of the hypothetical ventilator; b) picture of an electric rooftop ventilator

Siekiant geriau atskleisti ežektoriaus ir ventiliatoriaus sąveikini ryši STV veikimo metu, visų pirma panagrinèkime ištraukiamo oro charakteristikų kitimą irenginyje. Remiantis eksperimentinių tyrimų duomenimis, 3.10 paveiksle grafiškai pateikiama STV veikimą charakterizuojanti ištraukiamo srauto ir statinio slègio priklausomybè. 


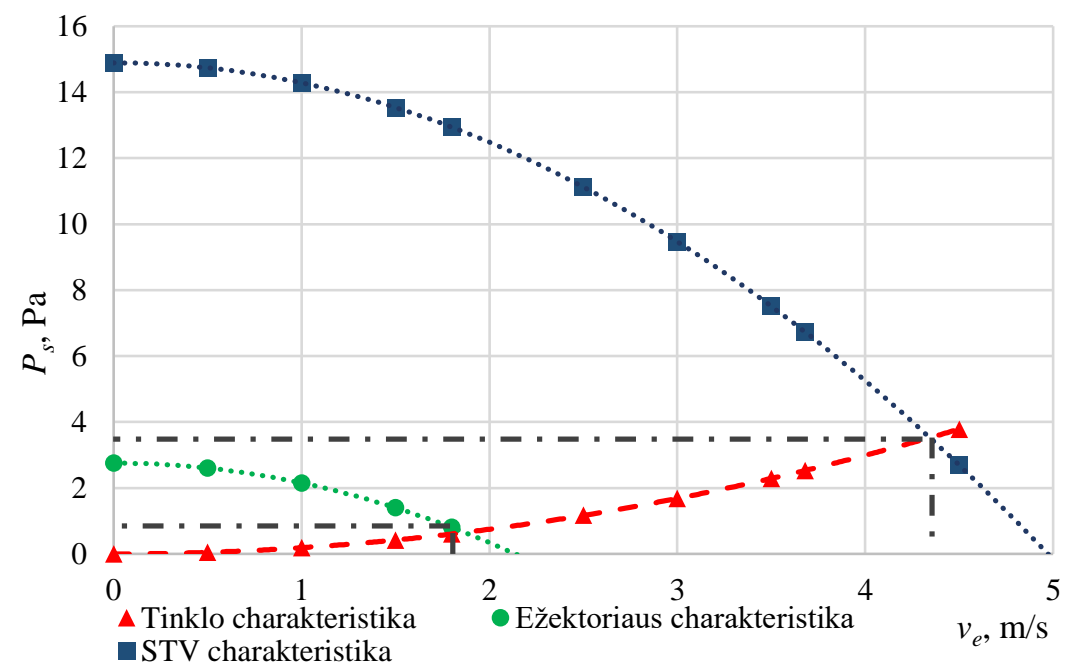

3.10 pav. Turbininio ventiliatoriaus sukuriamo debito ir statinio slègio charakteristikų palyginimas su ežektoriumi

Fig. 3.10. Comparison of created flow and static pressure characteristics of a turbine ventilator with an ejector

Grafike pateikta kylanti brūkšninė kreivè vaizduoja ịrenginio statinio slėgio priklausomybę nuo siurbimo kanalo skerspjūvyje $0-0$ tekančio oro greičio. Literatūroje ši priklausomybė dažnai ịvardinama tinklo charakteristika (angl system curve). Siuo atveju pateiktos kreivès statinio slègio nustatymui pakanka žinoti STV aerodinaminị pasipriešinimą ir siurbiamo oro greitị kanale:

$$
P_{s e}=\Delta P_{t e}-P_{d e}=\zeta \frac{\rho \cdot v_{e}^{2}}{2}-\frac{\rho \cdot v_{e}^{2}}{2}=\frac{\rho \cdot v_{e}^{2}}{2}(\zeta-1) .
$$

Grafiko apatinė žemėjanti kreivè vaizduoja STV menamo ežektoriaus eksperimentiškai nustatytas charakteristikas. Pateikta charakteristika nustatoma eksperimentų būdu, mechaniškai sustabdant STV rotorių. Kaip jau buvo minèta, eksperimentų metu pastebėta, jog sustabdžius STV rotorių ištraukiamo oro debitas sumažèja apie 2 kartus. Statinis slègis nesiurbiant oro srauto (pagal ventiliatorių analogiją - veikiant tuščia eiga) atitinka maksimalų sukuriamą ežektoriaus statinị slègi. Pastarasis rodiklis nustatomas eksperimentiškai, uždarant oro siurbimo kanalą (EN 13141-5, 2004).

Ivertinus STV tinklo charakteristiką bei nustatytą ežektoriaus debito ir statinio slėgio funkcinę priklausomybę, gaunamas šių kreivių susikirtimo taškas. Šis susikirtimo taškas atitinka STV veikimo parametrus (darbo tašką) tik dèl ežekcijos reiškinio. 
Viršutinė žemejjanti kreivė rodo STV, veikiančio ịprastu režimu, eksperimentiškai nustatytas debito ir slègio charakteristikas. Analogiškai ežektoriaus atvejui, tinklo ir STV charakteristikų kreivių susikirtimo taškas rodo irenginio darbo režimo parametrus. Abiem atvejais, vertinant ežektoriaus ir STV iprasto veikimo susikirtimo taškus, grafiškai galima nustatyti oro siurbimo procesui reikalingas galias. Iš susikirtimo taškų išvestos statmenos tiesès (juodos brūkšninès linijos) į abscisių ir ordinačių ašis riboja plotus, kurie atitinka teorines ežektoriaus ir STV generuojamas galias. Remiantis ventiliatorių skaičiavimo teorija, teorinè galia reikiamam oro srautui ištraukti iš patalpos nustatoma lygtimi:

$$
\dot{E}_{Q}=\Delta P_{t e} \cdot \dot{Q}_{e}=\frac{\xi \cdot \rho_{a} \cdot v_{e}^{3} \cdot A_{i}}{2},
$$

čia $\Delta P_{t e}-$ reikiamas pilnutinio slègio skirtumas ištraukiant oro srautą; $\dot{Q}_{e}-$ ištraukiamo oro debitas, $\mathrm{m}^{3} / \mathrm{s}$.

Grafiškai ir pagal 3.24 lygti akivaizdžiai matoma, jog dèl didèjančio oro greičio siurbimo kanale, sparčiai didejja statinis slègis. Todẻl, STV skerspjūvyje 0-0 padvigubejjus oro siurbimo debitui, ịrenginys turi užtikrinti 8 kartus didesnę galią.

Eksperimentiškai nustatyti debito ir sukuriamo slègio charakteristikas STV veikiant tik dèl rotoriaus poveikio - sudètinga. Šiuo atveju tyrime buvo atlikti bandymai STV rotorių sukant papildomu energijos šaltiniu be vejjo srauto ir palaikant ịprasto veikimo metu atitinkantị sukimosi dažnị. Kaip jau buvo minèta ankstesniame skyriuje, eksperimentų rezultatai parodé, jog įrenginį sukant vienodu dažniu be vejjo srauto, ištraukiamo oro debitas yra mažesnis apie $30 \%$ lyginant su ịprastu STV veikimu.

Pristatytų skirtingų bandymų sąlygų rezultatai akivaizdžiai parodè, jog STV pasižymi ežektoriui ir ventiliatoriui būdingomis savybèmis. Siekiant ịvertinti STV menamo ventiliatoriaus poveiki, modelyje priimama, jog ventiliatoriaus dedamoji atitinka skirtumą tarp STV charakteristikų iprasto veikimo metu ir eksperimentiškai nustatytų ežektoriaus charakteristikų. Remiantis šia prielaida, STV rotoriaus sukimasis prideda likusią pilnutinio slègio dalį:

$$
\Delta P_{t r}=\Delta P_{t e}-\Delta P_{t e j}=\zeta \cdot \frac{\rho \cdot v_{e}^{2}}{2}-\zeta \cdot \frac{\rho \cdot v_{e j}^{2}}{2}=\zeta \cdot \frac{\rho \cdot v_{e}^{2} \cdot\left(1-k_{e j}^{2}\right)}{2} .
$$

Detaliau nagrinejjant 3.10 paveiksle matomą ežektoriaus ir ventiliatoriaus tarpusavio sąveiką galima pastebèti ventiliatorių teorijoje pateiktą nuoseklaus ir lygiagretaus ịrenginių jungimo panašumų. Šiuo atveju, pagal teorijoje pateiktą analogiją, ežektorių ir ventiliatorių galima vertinti kaip skirtingas veikimo charakteristikas turinčius ịrenginius. Mokslinejje literatūroje nurodoma, jog esant nuosekliam įrenginių jungimui, rezultatyvi charakteristika atitinka šių atskirų 
ịrenginių statinių slègių sumą. Tuo tarpu, ịrenginius sujungus lygiagrečiai, bendra charakteristika nustatoma sudedant debitus. Remiantis šiais principais matoma, kad ežektoriaus ir ventiliatoriaus sąveika pasižymi abiems jungimo būdams būdingomis savybèmis. Tačiau kiekybiškai vertinant statinio slègio ir debito pokyčius, pastebimas didesnis lygiagrečiam jungimui būdingas poveikis.

Toliau detaliau aptarkime STV ventiliatoriaus dalyje vykstančius termodinaminius procesus vejjo tekejjimo kryptimi. Modelyje suskirstyti menami ventiliatorius ir turbina pagal savo konstrukciją yra tas pats įrenginys, todèl oro siurbimo metu vyksta tiesioginè šių įrenginių tarpusavio sąveika. Šis veikimo ryšys reiškia, kad turbinoje generuojama galia yra lygi ventiliatoriaus galiai $\dot{E}_{r}=\dot{E}_{t} .3 .11$ paveiksle pateikiama ventiliatoriaus termodinamini suspaudimo procesą vaizduojanti entalpijos-entropijos diagrama.

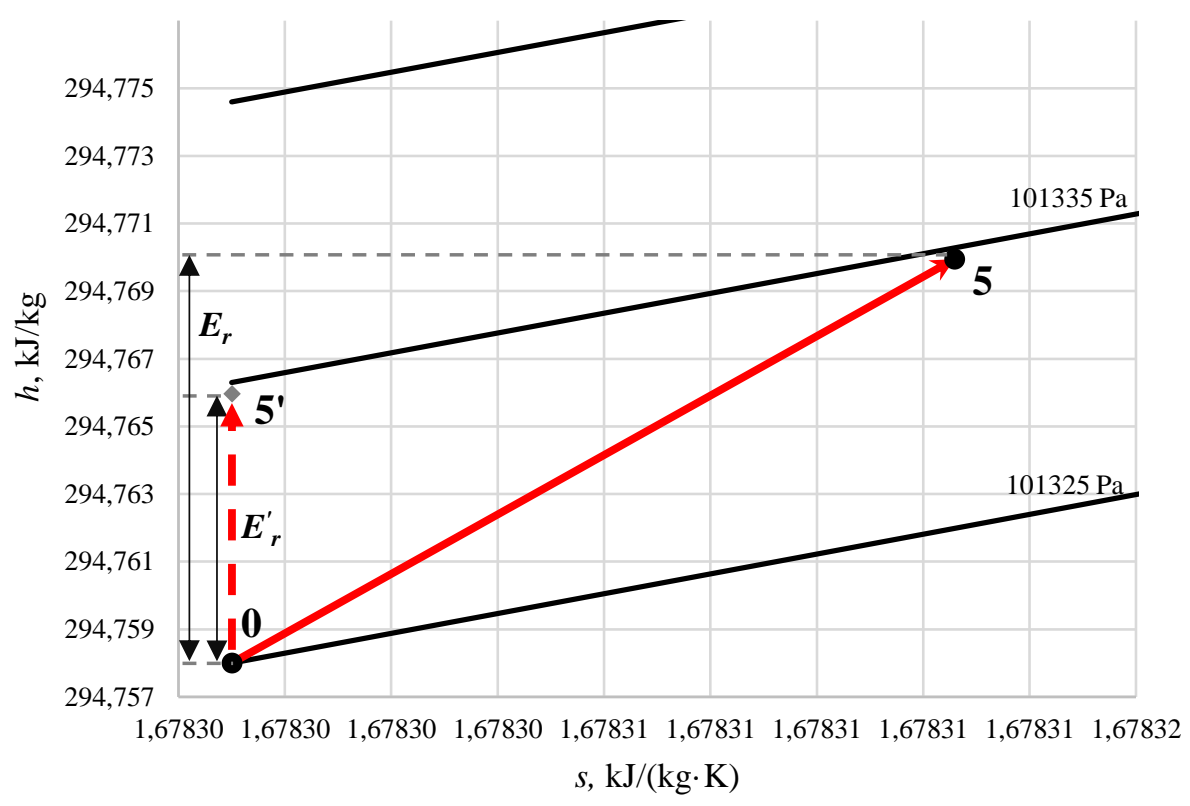

3.11 pav. $h$-s diagrama vaizduojanti menamo ventiliatoriaus dalyje vykstantị termodinaminị suspaudimo procesą

Fig. 3.11. $h$-s diagram of thermodynamic compression process in the hypothetical ventilator

Diagramoje pavaizduotas taškas 5 atitinka ventiliatoriumi siurbiamo oro srauto būsenos parametrus, o taškas 5' vaizduoja šio srauto būsenos parametrus esant idealiam grịžtamajam procesui. Pradiniai patalpos oro būsenos parametrai 
prieš siurbimą atitinka ežektoriaus nagrinejjamame atvejyje pavaizduotiems parametrams ir schemoje pavaizduoti tašku 0.

Ventiliatoriaus veikimo metu siurbiamam patalpos oro srautui suteikta energija $\dot{E}_{r}$ vaizduojama procesu $0-5$. Šiam procesui, taip pat taikomas izoentropinis srauto suspaudimo koeficientas $\eta_{r}$. Kadangi STV ežektorių ir ventiliatorių sieja tarpusavio konstrukcinis ryšys, jų izoentropiniai srauto suspaudimo koeficientai laikomi vienodais. Todèl, STV ventiliatoriaus izoentropinio koeficiciento skaitinè vertė atvirkščiai proporcinga STV aerodinaminio pasipriešinimo koeficientui:

$$
\eta_{r}=\eta_{e j s}=\frac{1}{\zeta}
$$

3.11 paveikslo diagramoje pavaizduoti taškai 5 ' ir 5 atitinka oro siurbimui reikalingo dinaminio slègio pokytị $\Delta P_{r}$, tačiau dèl susidarančių slègio nuostolių, pasislinkęs ị dešinę pusę taškas 5 rodo entropijos priaugị bei didesnę suspaudimo procesui reikiamą pilnają entalpiją. Atitinkamai, izoentropinị oro suspaudimo koeficientą galima užrašyti šia lygtimi:

$$
\eta_{r}=\frac{\left(h_{5}^{\prime}-h_{0}\right)}{\left(h_{5}-h_{0}\right)} .
$$

Fizikine prasme ši išraiška reiškia, jog ventiliatoriui idealiai suspaudžiant patalpos oro srautą, tam pačiam oro kiekiui ištraukti užtektų mažesnio energijos kiekio, todèl galioja sąlyga $\dot{E}_{r}>\dot{E}_{r}^{\prime}$. İvertinus menamo ventiliatoriaus komponento suteiktą galią, modelyje galioja lygybė:

$$
\dot{E}_{r}=\dot{M}_{r} \cdot\left(h_{5}-h_{0}\right) .
$$

STV ventiliatoriumi siurbimas oro srautas tekėdamas kanalu toliau patenka $i$ 4-4, 5-5 bei 6-6 skerspjūviais apribotą rotoriaus dalị. Šioje įrenginio dalyje vyksta skirtingų būsenos parametrų, vèjo, ežekcijos ir ventiliatoriumi siurbiamo oro maišymasis. Šiuo atveju priimama prielaida, jog STV veikimo metu visų pirma įvyksta ežekcijos ir vejo srautų maišymasis, o po to šis mišinys maišosi su ventiliatoriaus pasiurbtu oru.

Ivertinus oro srautų masinių debitu skirtumus bei entalpijos vertes, 3.11 paveikslo diagramoje galutinis maišymosi procesas vaizduojamas tašku 6 bei šiu procesų kryptị rodančiomis tiesėmis 4-6 ir 5-6. Proceso galutiniai entalpijos ir entropijos būsenų parametrai, pagal masinių debitų santykius atitinkamai apskaičiuojami šiomis lygtimis: 


$$
\begin{gathered}
h_{6}=\frac{\left(\dot{M}_{w i}+\dot{M}_{e j}\right) h_{4}+\dot{M}_{r} h_{5}}{\dot{M}_{w i}+\dot{M}_{e j}+\dot{M}_{r}} ; \\
s_{6}=\frac{\left(\dot{M}_{w i}+\dot{M}_{e j}\right) s_{4}+\dot{M}_{r} s_{5}}{\dot{M}_{w i}+\dot{M}_{e j}+\dot{M}_{r}} .
\end{gathered}
$$

Modelyje šie maišymosi proceso būsenos parametrai pateikiami kaip galutinis STV procesas.

\subsection{Menamų turbininio ventiliatoriaus komponentų veikimą integruojantis termodinaminis modelis}

Šiame poskyryje pateikiamas integruojantis termodinaminis modelis, kuris yra sudarytas pagal anksčiau pristatytą trikomponentę STV koncepciją. Šiuo atveju, remiantis atskirų komponentų termodinaminiais modeliais, sudaromas bendras STV modelis bei pateikiami analitiniai tokio modelio taikymo pavyzdžiai. Taip pat, šiame skyriuje pateikiama metodika įrenginių teorinio efektyvumo vertinimui.

\subsubsection{Turbininio ventiliatoriaus menamų komponentų tarpusavio sąveikos rezultatas}

Detalūs STV eksperimentiniai tyrimai ir jų pagrindu sudaryti atskirų komponentų skaitiniai modeliai, atvèrè galimybę energijos ir oro srautų balansų pagrindu integruoti anksčiau pristatytus komponentus i vieningą sistemą. Remiantis anksčiau pristatyta atskiru STV komponentu koncepcija, šioje dalyje detalizuojamas sudarytas integralus STV termodinaminis modelis.

Kaip jau buvo minèta, termodinaminis modelis sudaromas remiantis prielaida, jog oro srautu sąveikos procesai vyksta nuosekliai. Siekiant geriau suprasti STV vykstančių procesų eigą, 3.12 paveiksle pateikiama integrali turbinos, ežektoriaus ir ventiliatoriaus procesų principinè schema. 


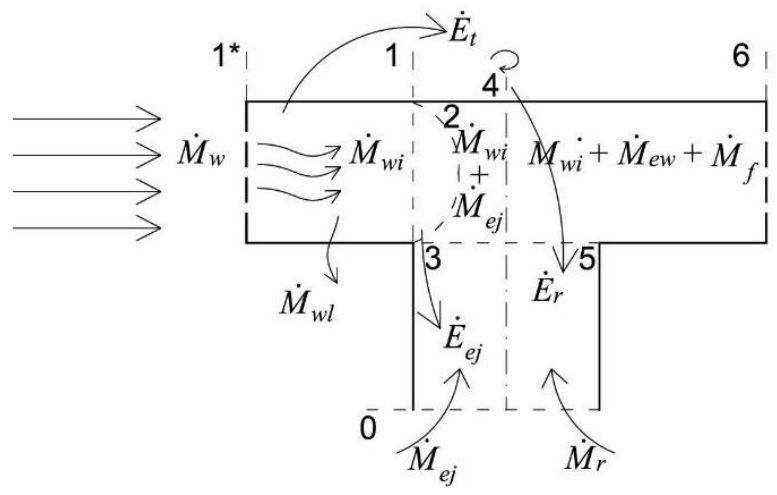

3.12 pav. Integrali turbininio ventiliatoriaus turbinos, ežektoriaus ir ventiliatoriaus termodinaminių srautų schema

Fig. 3.12. Integral scheme of thermodynamic flows of turbine ventilator's turbine, ejector and ventilator

Analizuojant pateiktą schemą, matoma kad STV veikimo metu vyksta šie termodinaminiai procesai:

$1 *-1$ proceso metu vejjo srautas veikdamas ịrenginio turbiną atlieka darbą, kuris yra tapatus STV ventiliatoriaus atliekamam darbui. Taip pat matoma, kad po sąveikos su rotoriumi, dalis vëjo srauto atitrūksta nuo rotoriaus.

1-2 proceso metu ị STV rotoriaus vidų patekęs vejo srautas toliau dalyvauja ežekcijos procese. Pasiurbdamas patalpos orą, vėjo srautas priskiriamas aktyviam srautui. Ežekcijos proceso metu, vejo srauto energija naudojama oro ištraukimui iš patalpos.

0-3 procesas rodo patalpos oro siurbimą dèl vykstančios ežekcijos.

2-4 ir 3-4 procesai vaizduoja vejjo srauto ir ežekcijos metu pasiurbto oro srauto maišymąsi.

0-5 procesas rodo STV ventiliatoriaus atliekamą patalpos oro siurbimą.

4-6 ir 5-6 procesų metu ịvyksta galutinis procesas, kurio metu maišosi ventiliatoriaus pasiurbtas oras su vejjo srauto ir ežekcija pasiurbto oro mišiniu.

Šių termodinaminių procesų vaizdavimas $h-s$ diagramoje pateiktas 3.13 paveiksle.

Pagal pateiktą STV vykstančių procesų seką galima pastebèti, jog termodinaminio modelio sudarymui būtina žinoti vèjo srauto galią tenkančią STV rotoriui. Tai galima nustatyti eksperimentiškai, tačiau esant kompleksiniams oro srautų procesams, toks būdas būtų sudètingas dèl ribotų galimybių atskirti vèjo ir ištraukiamo oro srautus. Šiuo atveju modelyje pasitelkiama energijos balanso lygtis: 


$$
\dot{M}_{w} \cdot\left(h_{1^{*}}-h_{0}\right) \cdot \eta_{t} \cdot \varepsilon_{t}=\dot{M}_{r} \cdot\left(h_{5}-h_{0}\right),
$$

čia $\varepsilon_{t}$ - vejjo srauto energijos dalis tenkanti STV rotoriui, vnt.

Pateikta balanso lygtis rodo menamų STV turbinos ir ventiliatoriaus funkcinę priklausomybę. Pagal lygties išraišką matoma, jog siurbiamam oro srautui suteikiama ventiliatoriaus galia taip pat tiesiogiai priklauso nuo turbinos izoentropinio naudingumo koeficiento. Pastarasis rodiklis šiame modelyje laikomas konstanta, kuri nustatoma eksperimentiškai arba imama iš mokslinès literatūros.

Kitas kintamasis būtinas termodinaminio modelio sudarymui - rotoriaus viduje esančio vejjo srauto galia tenkanti ežekcijai. Šiuo atveju modelyje taip pat pasitelkiama energijos balanso lygtis:

$$
\dot{M}_{w} \cdot k_{w l} \cdot\left(h_{1^{*}}-h_{0}\right) \cdot\left(1-\eta_{r} \cdot \eta_{t}\right) \cdot \eta_{e j} \cdot \varepsilon_{e j}=\dot{M}_{e j} \cdot\left(h_{3}-h_{0}\right),
$$

čia $\varepsilon_{e j}$ - vejjo srauto energijos dalis tenkanti STV ežektoriui, vnt.

Pateikta balanso lygtis rodo menamo STV ežektoriaus aktyvaus ir pasyvaus srautų funkcinę priklausomybę. Pagal lygties išraišką matoma, jog ežekcijos metu siurbiamam oro srautui suteikiama galia taip pat tiesiogiai priklauso nuo ežektoriaus izoentropinio naudingumo koeficiento. Be to, įvertinama ị rotoriaus vidų patenkanti likusi vejjo srauto dalis ir galia.

Pagal aukščiau pateiktas energijos balanso lygtis matoma, jog atlikus oro srautų siurbimą ežektoriumi ir ventiliatoriumu, modelio sprendimui taip pat būtina žinoti entalpijas šių procesų pabaigoje. Tam pasitelkiamos dar dvi energijos balanso lygtys. Pirmoji papildoma lygtis sudaroma menamų ežektoriaus ir ventiliatoriaus srautams suteiktų galių balansui, kuris išreikštas eksperimentiškai nustatytu STV siurbiamo oro srauto efektyvumu:

$$
\dot{M}_{r} \cdot\left(h_{5}-h_{0}\right)+\dot{M}_{e j} \cdot\left(h_{3}-h_{0}\right)=\dot{M}_{w} \cdot\left(h_{1^{*}}-h_{0}\right) \cdot \varepsilon_{Q},
$$

čia $\varepsilon_{Q}$ - irrenginio oro ištraukimo efektyvumas. Apskaičiuojamas ịvertinus santyki tarp teorinès oro ištraukimui reikalingos galis ir STV tenkančios vejjo srauto galios:

$$
\varepsilon_{Q}=\frac{\dot{E}_{Q}}{\dot{E}_{w}}=\frac{\zeta \cdot \rho \cdot v_{e}^{3} \cdot A_{i}}{\rho \cdot u^{3} \cdot A_{v e}},
$$

čia $\dot{E}_{Q}$ - teorinè ventiliatoriaus galia oro srauto ištraukimui, W; $\dot{E}_{w}-$ teorinė vëjo galia tenkant STV rotoriui, W. 
Antroji papildoma energijos balanso lygtis apibrèžia menamų STV turbinos ir ežektoriaus teorinių galių pasiskirstymo balansą:

$$
\dot{M}_{r} \cdot\left(h_{5}-h_{0}\right)=k_{p r} \cdot \dot{M}_{e j} \cdot\left(h_{3}-h_{0}\right),
$$

čia $k_{p r}$ - STV rotoriumi siurbiamo oro srauto ir ežektuojamo oro srauto santykis. Nustatoma pagal eksperimentinių tyrimų duomenis:

$$
k_{p r}=\frac{\dot{E}_{r}}{\dot{E}_{e j}}=\frac{\dot{E}_{Q}-\dot{E}_{e j}}{\dot{E}_{e j}}=\frac{\dot{E}_{Q}}{\dot{E}_{e j}}-1=\frac{1}{k_{e j}^{3}}-1,
$$

čia $\dot{E}_{r}-\mathrm{STV}$ rotoriumi siurbiamo oro srautui reikalinga galia, W; $\dot{E}_{e j}-\mathrm{STV}$ ežekcijai reikalinga galia, W.

Remiantis pateiktomis energijos balanso lygtimis, modelio sprendimui sudaroma lygčių sistema:

$$
\left\{\begin{array}{l}
\dot{M}_{w} \cdot\left(h_{1^{*}}-h_{0}\right) \cdot \eta_{t} \cdot \varepsilon_{t}=\dot{M}_{r} \cdot\left(h_{5}-h_{0}\right) \\
\dot{M}_{w} \cdot k_{w l} \cdot\left(h_{1^{*}}-h_{0}\right) \cdot\left(1-\eta_{r} \cdot \eta_{t}\right) \cdot \eta_{e j} \cdot \varepsilon_{e j}=\dot{M}_{e j} \cdot\left(h_{3}-h_{0}\right) \\
\dot{M}_{r} \cdot\left(h_{5}-h_{0}\right)+\dot{M}_{e j} \cdot\left(h_{3}-h_{0}\right)=\dot{M}_{w} \cdot\left(h_{1^{*}}-h_{0}\right) \cdot \varepsilon_{Q} \\
\dot{M}_{r} \cdot\left(h_{5}-h_{0}\right)=k_{p r} \cdot \dot{M}_{e j} \cdot\left(h_{3}-h_{0}\right)
\end{array} .\right.
$$

Atlikus šios lygčių sistemos sprendimą nustatyta, jog modeliui reikalingi parametrai gali būti apskaičiuojami šiomis formulèmis:

$$
\begin{gathered}
\varepsilon_{t}=\frac{\varepsilon_{Q} \cdot k_{p r}}{\left(\eta_{t}\left(1+k_{p r}\right)\right)} \\
\varepsilon_{e j}=\frac{\varepsilon_{Q}}{k_{w l} \cdot \eta_{e j}\left(1+k_{p r} \cdot\left(1-\varepsilon_{Q}\right)\right)} \\
h_{3}=h_{0}+\frac{\dot{M}_{w} \cdot \varepsilon_{Q} \cdot\left(h_{w}-h_{0}\right)}{\dot{M}_{e j}\left(1+k_{p r}\right)} \\
h_{5}=h_{0}+\frac{\dot{M}_{w} \cdot \varepsilon_{Q} \cdot k_{p r} \cdot\left(h_{w}-h_{0}\right)}{\dot{M}_{r}\left(1+k_{p r}\right)} .
\end{gathered}
$$


Taikant šias energijos balanso lygčių pagrindu nustatytas lygtis bei priimant prielaidas dèl ịrenginio izoentropinių naudingumo koeficientų - galima sudaryti $h$-s diagramą vaizduojančią STV vykstančių oro srautų procesų kitimą. Pristatomo modelio skaitiniu pavyzdžiu pasirinktas STV2 įrenginys, kurio rotoriaus mentės lenktos vertikalios ašies kryptimi. Skaitiniame pavyzdyje apsiribojama maksimaliu eksperimentų metu pasiektu vejjo greičiu $(9,2 \mathrm{~m} / \mathrm{s})$, o izoentropiniai koeficientai nustatyti atsižvelgiant ị mokslinejje literatūroje pateiktus duomenis (Fang Liu \& Groll, 2013). Modelyje priimama, jog turbinos ir ežektoriaus izoentropinių koeficientų vertès yra 0,8 , o atitrūkusios vèjo srauto dalies koeficientas 0,7 .

3.13 paveikslo $h-s$ diagramoje pateikiamas integralus STV2 įrenginio termodinaminių procesų skaitinis atvejis.

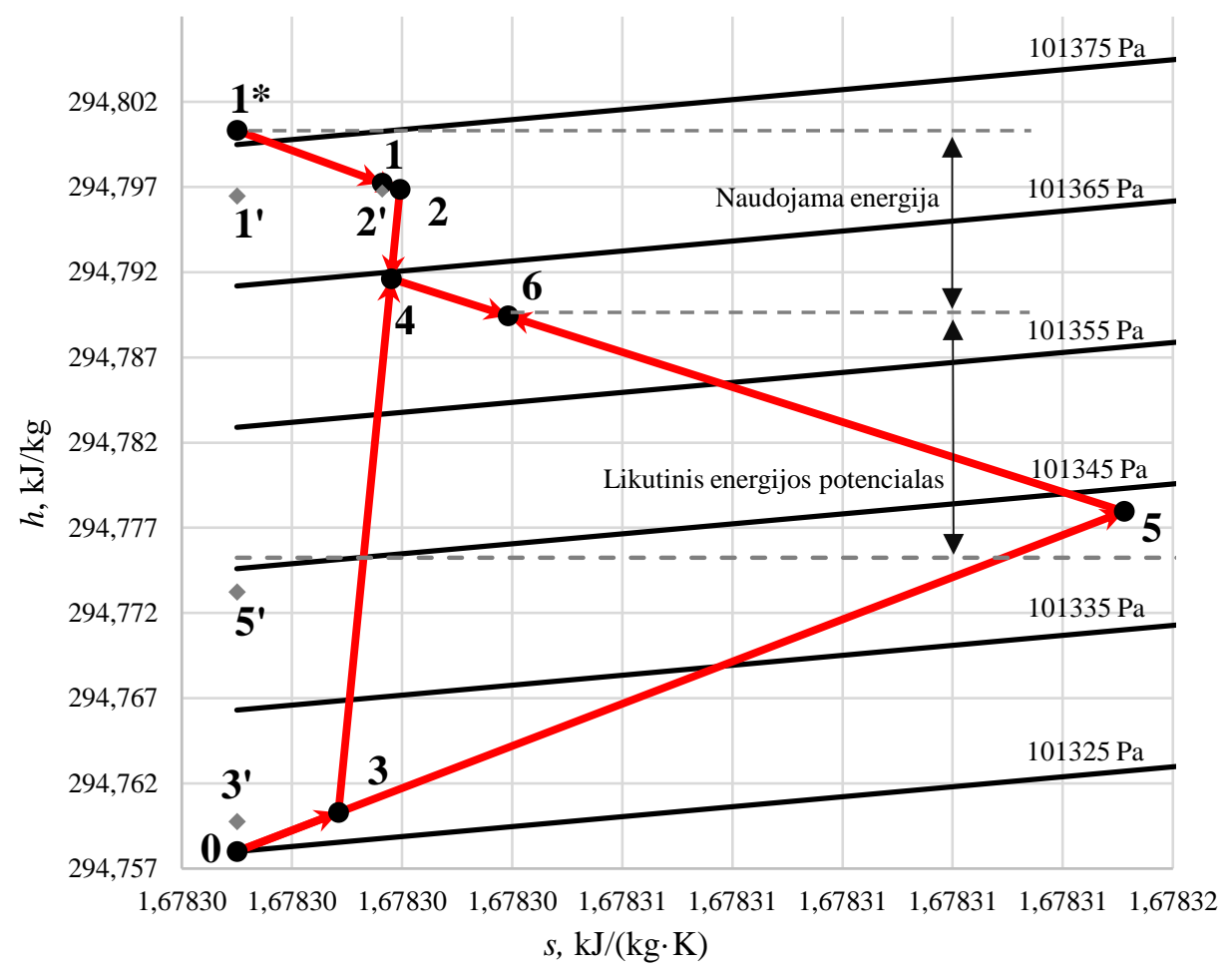

3.13 pav. Integrali STV2 termodinaminų procesų $h$-s diagrama Fig. 3.13. Integral $h$-s diagram of RTV2 thermodynamic processes

Pateikto modelio skaitiniu atveju matoma, kaip pučiant vejjo srautui į STV, dalis šio srauto energijos sunaudojama rotoriaus sukimui, o kita dalis sunaudojama ežekcijos proceso metu. Be to, analizuojant rezultatus matoma, jog 
ịrenginiu pratekantis oro srautas turi turèti pakankamai energijos ištekejjimui iš STV vidaus. Vertinant maksimalų vejo srauto energijos panaudojimą remiamasi vejo jejgainèse taikoma teorine Betzo kriterijaus riba. Termodinaminiame modelyje priimama, jog esant maksimaliam įrenginio efektyvumui, teoriškai vẻjo srauto energija gali sumažèti ne daugiau 59,3\%. Šiuo atveju 3.13 paveiksle nubrèžta horizontali brūkšninė tiesė atitinka Betzo kriterijaus ribą, kuri rodo visų STV viduje susimaišiusių oro srautų teorinę būsenos parametrų ribą.

Remiantis šio atvejo rezultatais nustatyta, jog iš įrenginio ištekančio oro srauto energija sumažéja 25,7 \% (diagramoje žymima „Naudojama energija“), palyginus su pradine vejo srauto energija. Tuo tarpu, ịvertinus Betzo kriterijaus ribą, nepanaudotos energijos potencialas siekia 33,6 \% (diagramoje žymima „Likutinis energijos potencialas").

\subsubsection{Teorinis turbininių ventiliatorių efektyvumo palyginimas}

Pasitelkus pristatytą termodinaminį modelį, atliekamas bandytų STV rezultatų skaičiavimas. Šiuo atveju taikant modelị siekiama įvertinti skirtingų STV komponentų efektyvumo rodiklius. Atliekant analizę remiamasi eksperimentinių tyrimų duomenimis, o modeliui reikalingi izoentropiniai ir atitrūkusio vejjo srauto dalies koeficientai priimami lygūs anksčiau pristatytam skaitiniam atvejui. 3.1 lentelèje pateikiama modelio analizèje naudojamų kintamųjų suvestinè.

3.1 lentelè. Termodinaminio modelio analizèje naudojami kintamieji

Table 3.1. Variables used in the analysis of the thermodynamic model

\begin{tabular}{|c|c|c|c|}
\hline \multirow{2}{*}{$\begin{array}{c}\text { Modelio } \\
\text { kintamieji }\end{array}$} & STV1 & STV2 & STV3 \\
\cline { 2 - 4 } & \multicolumn{3}{|c|}{ Irenginys } \\
\hline$Q_{e}, \mathrm{~m}^{3} / \mathrm{h}$ & 116 & 9,2 & 9,2 \\
\hline$A, \mathrm{~m} 2$ & 0,022 & 171 & 183 \\
\hline$d_{i}, \mathrm{~m}$ & 0,128 & 0,019 & 0,027 \\
\hline$\zeta$ & 2,42 & 0,118 & 0,15 \\
\hline$k_{e j}$ & 0,59 & 1,31 & 2,65 \\
\hline$k_{w l}$ & 0,7 & 0,43 & 0,65 \\
\hline$\eta_{t}$ & 0,8 & 0,7 & 0,7 \\
\hline$\eta_{e j}$ & 0,8 & 0,8 & 0,8 \\
\hline
\end{tabular}


Modeliavimo metu siekiama nustatyti kokia vejjo srauto energijos dalis tenka STV rotoriui bei ežektoriui. Šiuo atveju tam taikomi ir skaičiuojamieji rodikliai. Taip pat, parengtas termodinaminis modelis leidžia įvertinti bendrą vejjo srauto energijos naudojimo efektyvumą:

$$
\varepsilon_{w}=\frac{h_{1^{*}}-h_{6}}{h_{1^{*}}-h_{0}} .
$$

3.14 paveiksle pateikiamas skirtingų įrenginių efektyvumo rodiklių palyginimas.

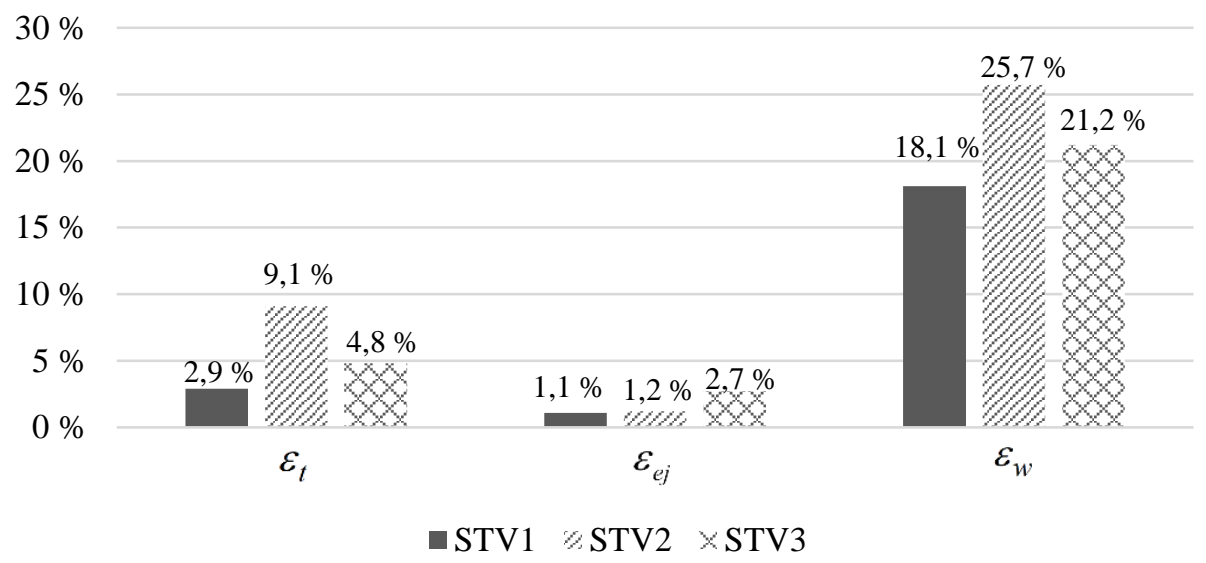

3.14 pav. Bandytų turbininių ventiliatorių efektyvumo rodiklių palyginimas

Fig. 3.14. Comparison of tested turbine ventilators efficiency indicators

Pristatytas termodinaminis modelis atveria galimybę ịvertinti STV komponentų ịtaką ịrenginyje vykstantiems procesams, jų veikimo tobulinimui ir bendrajam STV efektyvumui gerinti. Remiantis atliktų skaičiavimų duomenimis matoma, jog visais atvejais didesnè vèjo srauto energijos dalis tenka STV ventiliatoriui. Lyginant bandytus STV, geriausiai vèjo energiją išnaudoja STV2 irenginio rotorius, o mažiausia dalis tenka STV1 rotoriui. Taikant termodinaminị modeli apskaičiuota, jog STV1 rotorius sunaudoja 2,9\% véjo energijos, atitinkamai STV2 ir STV3 šie rodikliai siekia 9,1\% ir 4,8\%.

Vertinant ịrenginių ežektorių komponentus matoma, kad didžiausia aktyvaus vejjo srauto energija naudojama STV3 įrenginyje, o STV1 ir STV2 šie rodikliai yra panašūs. Šiuo atveju STV1, STV2, STV3 ežekcijai tenkanti vejo srauto energijos dalis atitinkamai siekia $1,1 \%, 1,2 \%$ ir 2,7 \%. Apskaičiavus nustatyta, jog bandytų STV vejo energijos naudojimo pasiskirstymas yra skirtingas. Lyginant rezultatus tarpusavyje, matoma, kad tobulinant įrenginius vertetų 
atsižvelgti ị STV1, STV3 rotorių konstrukciją. Tuo tarpu siekiant pagerinti STV2 efektyvumą, pastebimas ežektoriaus komponento tobulinimo potencialas.

Analizuojant bendraji vejjo srauto energijos naudojimo efektyvumą matoma, kad STV2 įrenginys rodo geriausią rezultatą, o STV1 - blogiausią. Šiuo atveju STV2 atitinka anksčiau pristatyto skaitinio atvejo rezultatą - 25,7 \%, o STV1, STV3 atitinkamai siekia $18,1 \%$ ir 21,2 \%. Nustatyti rezultatai rodo, jog visų STV vejjo energijos naudojimas yra daugiau nei 2 kartus mažesnis už galimą teorinę Betzo kriterijaus ribą.

\subsection{Turbininių ventiliatorių funkcionalumo padidinimo vertinimas}

Remiantis eksperimentinių tyrimų rezultatais, šiame poskyryje atliekamas teorinis turbininių ventiliatorių funkcionalumo padidinimo vertinimas bei pateikiamos techninès galimybès šị ịrenginị integruoti ị hibridinę vẻdinimo sistemą. Realiomis sąlygomis, vejjo greitis lauke pulsuoja, kinta stochastiškai, todèl ištraukiamas nepastovus oro srautas. Siekiant padidinti védinimo sistemos funkcionalumą, STV numatoma taikyti energijos akumuliavimui esant perteklinei vejjo energijai ir tokiu būdu ilgiau užtikrinti reikiamą oro kaitą.

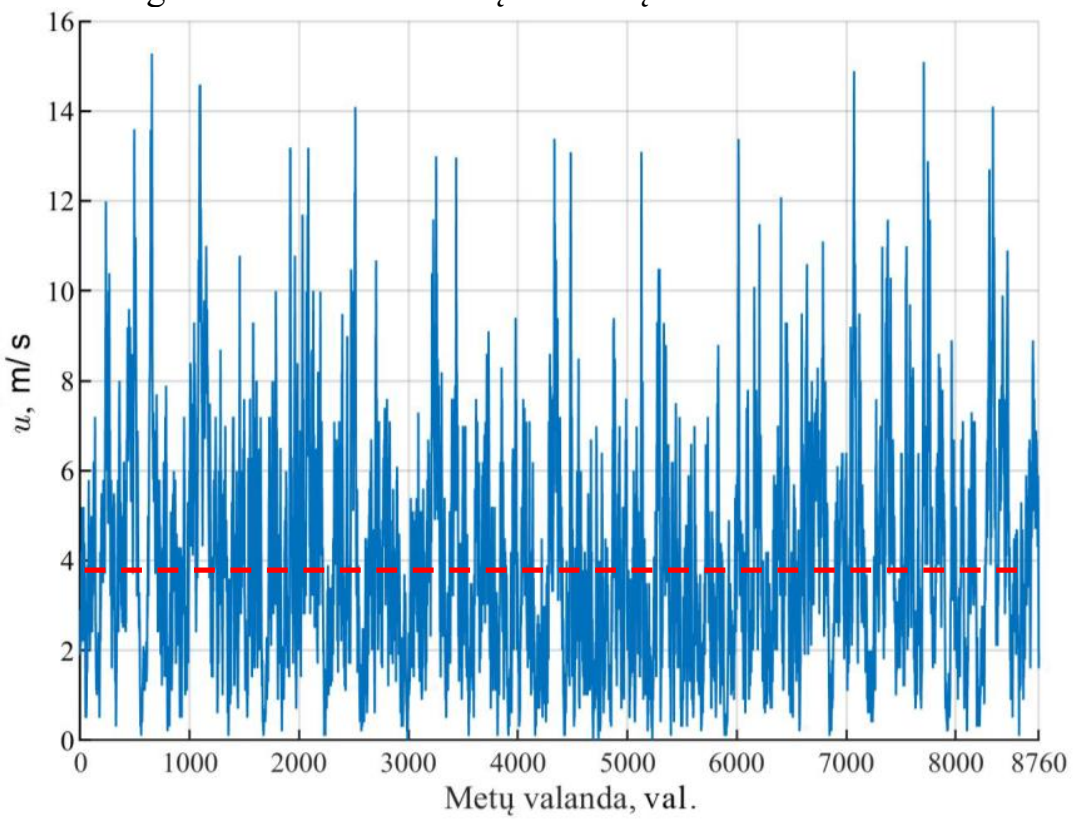

3.15 pav. Metinis vejjo greičio kitimas Vilniuje

Fig. 3.15. Annual variation of wind speed in Vilnius 
Atliekant metinio STV ištraukiamo oro skaičiavimus pasirenkamas Vilniaus mieste esantis hipotetinis pastatas, virš kurio stogo nekliudomai pučia vietovei būdingas vejo srautas. Vilniaus miesto vejjo greičio kitimas priimamas pagal „Meteonorm“ programoje pateikiamas vejjo greičio vertes $10 \mathrm{~m}$ aukštyje.

Metinis vejo greičio kitimas Vilniuje pateiktas 3.15 paveiksle. Skaičiavimams taikomas grafikas sudarytas 1 minutès intervalu. Pagal grafiko duomenis matoma, kad vejo greitis mieste yra pulsuojantis. Vertinant pateiktus duomenis nustatyta, jog vejjo greitis mieste kinta diapazone nuo $0 \mathrm{~m} / \mathrm{s}$ iki 15,3 m/s, o vidurkis yra apie $3,9 \mathrm{~m} / \mathrm{s}$ (grafike pavaizduota raudona brūkšnine linija).

Skaičiuojant STV ištraukiamo oro srautą priimama, jog statinis slègis vėdinamame pastate ir lauke yra lygūs, nèra gravitacijos jègų, todèl tolesniems skaičiavimams taikoma 2.18 empirinè lygtis bei 2.4 lenteleje pateikti koeficientai. Remiantis šia empirine lygtimi bei metinio vejo greičio kitimo grafiku, apskaičiuojamas metinis STV ištraukiamas oro srautas (3.16 pav.).

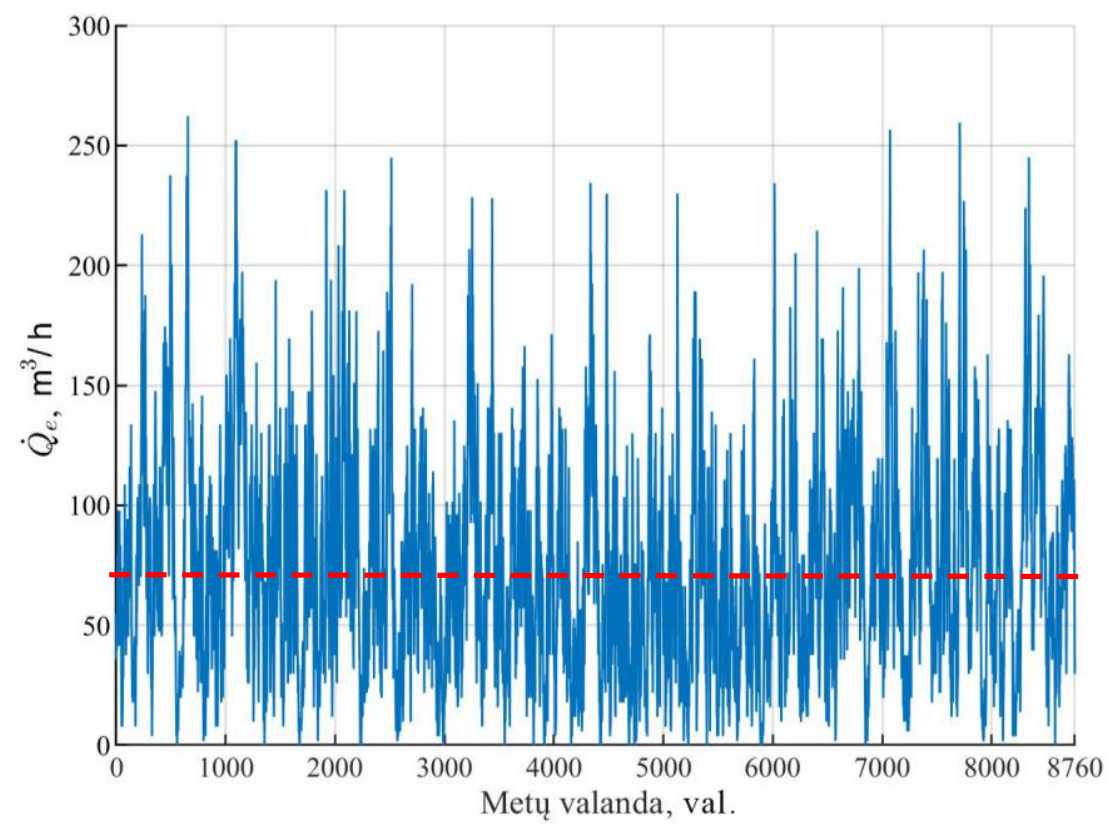

3.16 pav. Metinis turbininio ventiliatoriaus ištraukiamo oro srauto kitimas Fig. 3.16. Annual variation of turbine ventilator's extracted airflow

Pateiktas grafikas rodo metinị ištraukiamo oro srauto kitimą esant ịprastiniam STV veikimui ant pastato stogo. Apskaičiavus nustatyta, jog ištraukiamas oro srautas esant tokioms veikimo sąlygoms gali kisti nuo $0 \mathrm{~m}^{3} / \mathrm{h}$ iki $261 \mathrm{~m}^{3} / \mathrm{h}$. 
Bendras metinis ištraukiamas oro srautas siekia $6,45 \cdot 10^{5} \mathrm{~m}^{3} / \mathrm{h}$, o vidurkis apie $74 \mathrm{~m}^{3} / \mathrm{h}$.

Atliekant tolesnius skaičiavimus priimama, jog STV projektuojamas pagal vidutinị metinį vietovès vejo greitic $3,9 \mathrm{~m} / \mathrm{s}$ ir vidutini ištraukiamo oro srautą $\bar{Q}_{e}=74 \mathrm{~m}^{3} / \mathrm{h}$. Be to, hipotetiniam pastatui reikiamas oro kiekis vertinamas pagal ASHRAE standartą. Priimama, jog pastatas bus sandèliavimo paskirties, todèl atsižvelgiant $i$ tai taikomas minimalus oro debitas védinimui yra $0,31 /\left(\mathrm{s} \cdot \mathrm{m}^{2}\right)$. Ivertinus šiuos kriterijus, STV projektuojamas patalpai kurios grindų plotas yra $68,5 \mathrm{~m}^{2}$.

Toliau pateikiamas vejo energijos akumuliavimo potencialas hibridinès védinimo sistemos funkcionalumo padidinimui. Analizuojant vejjo energijos akumuliavimo potencialą visų pirma sudaroma vejjo greičio kumuliacinė kreivė (3.17 pav.).

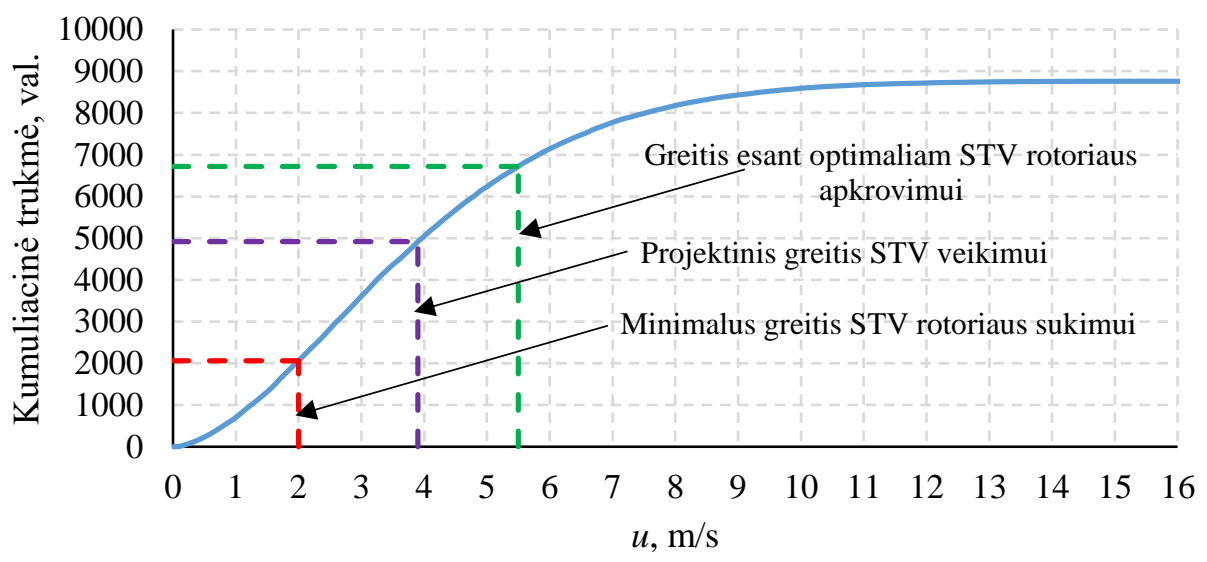

3.17 pav. Vilniaus miesto vèjo greičio kumuliacinè kreivè

Fig. 3.17. Cumulative curve of wind speed in Vilnius

Pateikta kumuliacinė kreivė papildomai suskirstyta pagal 3 ribines sąlygas. Pirmoji ribinè sąlyga rodo vejjo greitị bei kumuliacinę trukmę kuomet nesisuka STV rotorius. Śiuo atveju STV rotorius pradeda suktis esant minimaliam eksperimentiškai nustatytam $2 \mathrm{~m} / \mathrm{s}$ vejjo greičiui. Pagal sudarytą kumuliacinę kreivę matoma, kad STV rotorius per metus nesisuktų apie $23 \%$ laiko (2000 val.). Esant šioms sąlygoms ištraukiamas oro srautas priklausytų tik nuo ežekcijos, tačiau dèl mažo vèjo greičio šis kiekis yra neženklus.

Diapazone nuo $2 \mathrm{~m} / \mathrm{s}$ iki 3,9 m/s STV ištraukiamas oro srautas būtų mažesnis nei numatytas projektinis $74 \mathrm{~m}^{3} / \mathrm{h}$. Tokios sąlygos per metus sudaro apie $34 \%$ (2950 val.). Esant didesniam nei projektiniam vèjo greičiui, STV ištraukiamas oro 
srautas viršytų hipotetiniam pastatui reikalingą oro srautą. Šiuose skaičiavimuose, tokios sąlygos vertinamos kaip perteklinès vejjo energijos akumuliavimo potencialas. Apkraunant STV rotorių ir priklausomai nuo pasirinkto energijos kaupimo būdo, ši perteklinè energija galètų būti transformuojama ị mechaninę ar elektrocheminę energiją. Tokios vẻjo greičio sąlygos gali būti papildomai suskirstytos ị dalinị rotoriaus apkrovimą bei optimalų rotoriaus apkrovimą.

Dalinio apkrovimo sąlygos susidaro tuomet, kai STV rotorius gali ištraukti projektinį oro srautą bei generuoti perteklinę energiją. Tokio apkrovimo metu, rotoriaus sukimosi dažnis yra ribojamas atsižvelgiant i projektini oro srautą. Remiantis 2.16 paveiksle pateiktais eksperimentų rezultatais nustatyta, kad dalinis apkrovimas galimas iki $5,5 \mathrm{~m} / \mathrm{s}$ vejo greičio. Pasiekus šią ribą, STV veikimas tampa funkcionaliai optimalus - STV gali ištraukti projektini oro debitą bei tuo pačiu rotoriumi generuoti maksimalią galią (esant $5,5 \mathrm{~m} / \mathrm{s}$ vèjo greičiui). Tokios vèjo sąlygos per metus sudaro apie $22 \%$ laiko (1900 val.).

Kai vèjo greitis yra didesnis nei $5,5 \mathrm{~m} / \mathrm{s}$, STV siekiama išnaudoti maksimaliam energijos generavimui ir kaupimui. Esant tokiam veikimo režimui, STV ištraukiamas oro srautas tampa didesnis net ir optimaliai apkrovus rotorių. Šios sąlygos sudaro apie $22 \%$ laiko (1920 val.).

3.18 paveiksle pateikiama vejjo greičio histograma ir STV veikimo režimus apibūdinančios ribos įrenginiui veikiant hibridinejje vėdinimo sistemoje.

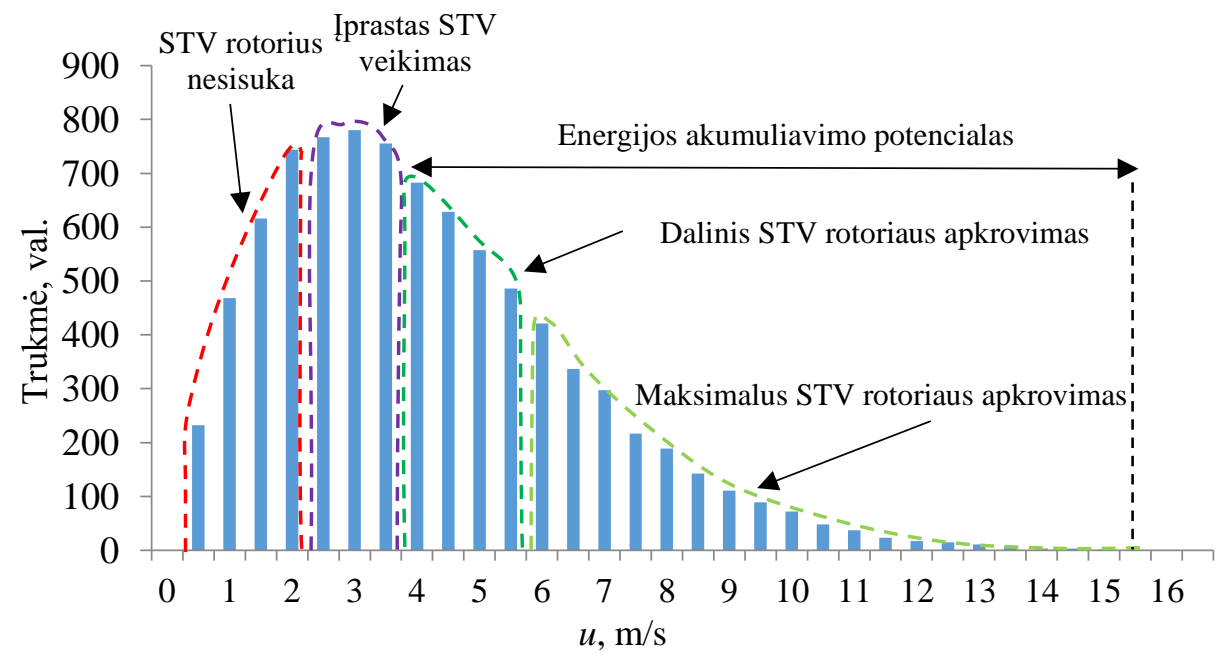

3.18 pav. Vejo greičio histograma ir galimi turbininio ventiliatoriaus veikimo režimai hibridineje vėdinimo sistemoje

Fig. 3.18. Histogram of wind speed and feasible turbine ventilator's operation regimes in hybrid ventilation system 


\subsubsection{Perteklinès vèjo energijos akumuliavimo potencialo skaičiavimas}

Kiekybinis perteklinès vejjo energijos akumuliavimo potencialo nustatymas apima STV2 ịrenginio eksperimentu empirines lygtis bei nustatytas fizikines priklausomybes. Siekiant apskaičiuoti akumuliavimo potencialą, visų pirma reikalinga ịrenginio rotoriaus maksimalaus sukimosi dažnio priklausomybè nuo vejjo greičio. Eksperimentiškai nustatyta, jog ši priklausomybė yra tiesinė:

$$
\omega_{\max }=a_{\omega} \cdot u+b_{\omega},
$$

čia $a_{\omega}, b_{\omega}$ empiriniai koeficientai, nustatyti pagal eksperimentinių tyrimų duomenis ir STV2 atveju atitinkamai lygūs 57,15 ir 27,24. Šiuo atveju empirinè lygtis galioja kai $u>2 \mathrm{~m} / \mathrm{s}$.

Kita skaičiavimams reikalinga empirinè lygtis - STV ištraukiamas oro srautas veikiant tik ežekcijai. Ši empirinè lygtis nustatoma eksperimentų metu visiškai sustabdžius STV rotorių:

$$
\dot{Q}_{e b}=a_{b} \cdot u^{2}+b_{b} \cdot u+c_{b},
$$

čia $a_{b}, b_{b}, c_{b}$ empiriniai koeficientai, nustatyti pagal eksperimentinių tyrimų duomenis ir STV2 atveju atitinkamai lygūs $-0,172,10,18$ ir $-1,45$. Šiuo atveju empirinè lygtis galioja kai $u>2 \mathrm{~m} / \mathrm{s}$.

Kadangi energijos akumuliavimas gali būti atliekamas esant daliniam ir maksimaliam STV rotoriaus apkrovimui - skaičiavimai atskirai suskirstomi i dvi dalis.

Skaičiuojant STV rotoriumi generuojamą galią veikiant dalinio apkrovimo režimu reikalinga žinoti galimą sukimosi dažni rotoriaus apkrovimo metu. Pastarasis rodiklis turi būti apskaičiuojamas taip, kad apkrovos metu nesumažètų ištraukiamas oro kiekis. Eksperimentiškai nustatyta, jog apkraunant rotorių, ištraukiamas oro srautas nuo $\dot{Q}_{e}$ iki $\dot{Q}_{e b}$ ribos mažèja tiesiškai (2.15 pav. rezultatai). Remiantis šia fizikine priklausomybe, galima sudaryti lygybę, leidžiančią apskaičiuoti apkrauto rotoriaus sukimosi dažnį, kuris reikalingas projektiniam oro srautui siurbti:

$$
\omega_{r}=\omega_{\max } \frac{\dot{Q}_{e r}-\dot{Q}_{b}}{\dot{Q}_{e}-\dot{Q}_{b}} .
$$

Žinant reikiamą sukimosi dažni rotoriaus apkrovimo metu, toliau galima atlikti generuojamos galios skaičiavimus. Remiantis eksperimentinių tyrimų duomenis nustatyta, jog STV maksimalus sukimo momentas nuo vèjo greičio kinta kvadratu, todèl galima taikyti lygtị: 


$$
\tau_{\max }=a_{\tau} \cdot u^{2}+b_{\tau} \cdot u+c_{\tau},
$$

čia $a_{\tau}, b_{\tau}, c_{\tau}$ empiriniai koeficientai, nustatyti pagal eksperimentinių tyrimų duomenis ir STV2 atveju atitinkamai lygūs $4,79 \cdot 10^{-4}, 2,74 \cdot 10^{-5}$ ir $-7,63 \cdot 10^{-4}$. Pateikta empirinè lygtis galioja kai $u>2 \mathrm{~m} / \mathrm{s}$.

Ivertinus eksperimentiškai nustatytą tiesinę priklausomybę tarp sukimo momento ir sukimosi dažnio, sudaroma sukimo momento skaičiavimo lygtis esant daliniam rotoriaus apkrovimui:

$$
\tau_{r}=\tau_{\max }-\tau_{\max } \frac{\omega_{r}}{\omega_{\max }}=\tau_{\max }\left(1-\frac{\omega_{r}}{\omega_{\max }}\right) .
$$

Pritaikius 2.10 lygti, STV generuojama galia dalinio apkrovimo metu apskaičiuojama:

$$
\dot{E}_{S T V}=\frac{\pi}{30} \cdot \tau_{\max }\left(1-\frac{\omega_{r}}{\omega_{\max }}\right) \cdot \omega_{r} .
$$

İstačius $\omega_{r}$ išraišką:

$$
\dot{E}_{S T V}=\frac{\pi}{30} \cdot \tau_{\max } \cdot \omega_{\max } \cdot \frac{\dot{Q}_{e r}-\dot{Q}_{b}}{\dot{Q}_{e}-\dot{Q}_{b}} \cdot\left(1-\frac{\dot{Q}_{e r}-\dot{Q}_{b}}{\dot{Q}_{e}-\dot{Q}_{b}}\right) .
$$

Esant didesniam nei $5,5 \mathrm{~m} / \mathrm{s}$ vèjo greičiui, rotorius gali būti apkraunamas optimaliai ir tokiu būdu generuoti maksimalią galią. Eksperimentiškai ir skaičiavimo rezultatais nustatyta, jog maksimali generuojama galia pasiekiama tuomet, kai rotoriaus sukimosi dažnis ir maksimalus sukimo momentas sumažèja per pus. Atsižvelgiant ị tai, vèjo greičiui viršijus $5,5 \mathrm{~m} / \mathrm{s}$, maksimali generuojama galia apskaičiuojama lygtimi:

$$
\dot{E}_{S T V}=\frac{\pi}{30} \cdot \frac{\tau_{\max } \cdot \omega_{\max }}{4} .
$$

Verta paminèti, jog esant tokiam veikimo režimui, STV ištraukiamas oro srautas viršys projektinị oro debitą. Istačius $\dot{Q}_{e}, \omega_{\max }, \tau_{\max }$ empirines lygtis galime apskaičiuoti generuojamas galias dalinio ir maksimalaus STV rotoriaus apkrovimo metu. Toliau esančiame 3.19 paveiksle pateikiamas metinis STV2 generuojamos galios kitimas, kuomet įrenginys tuo pačiu metu atlieka vẻdinimą. 


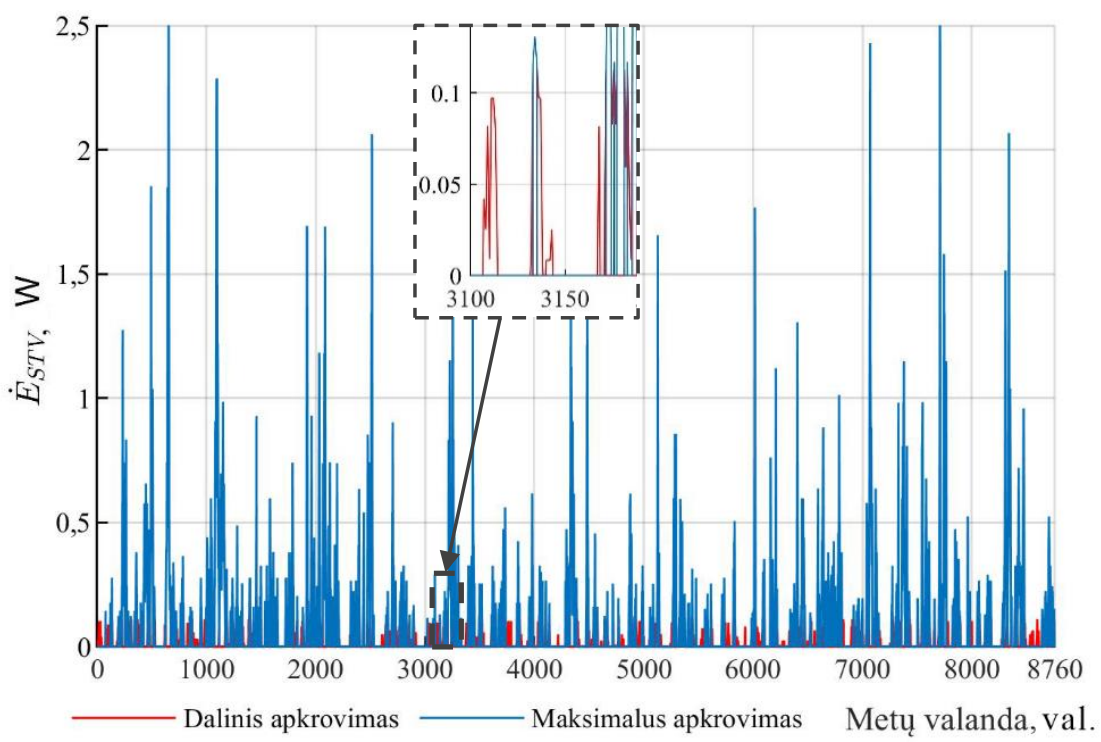

3.19 pav. Metinis STV2 generuojamos galios kitimas

Fig. 3.19. Annual variation of RTV2 generated power

Grafike pateikti rezultatai padalinti ị dalinio apkrovimo rezultatus (raudonos kreivès) ir maksimalaus apkrovimo rezultatus (mėlynos kreivès). Apskaičiavus nustatyta, jog dalinio apkrovimo metu STV2 gali generuoti iki $0,11 \mathrm{~W}$, o maksimalaus apkrovimo atveju iki 2,6 W. Atkreipiamas dèmesys, jog šiame tyrime naudotas STV yra nedidelis, be to, dažnai pastatuose tokių įrenginių įrengiama daugiau nei vienas. Esant kitokioms sąlygoms, galima tikètis ženkliai didesnių generuojamų galių bei tuo pačiu didesnio akumuliuojamo energijos kiekio.

Metinis STV2 akumuliuotos energijos potencialas pateikiamas 3.20 paveiksle. Apskaičiavus perteklinès vejjo energijos akumuliavimo potencialą nustatyta, jog STV2 per metus iš viso galètų akumuliuoti apie 828 Wh energijos. STV2 veikdamas dalinio apkrovimo metu (vejo greitis 3,9-5,5 m/s) sugeneruotuc $92 \mathrm{Wh}$ energijos. Veikdamas maksimalus aprovimo metu (vejjo greitis $3,9-5,5 \mathrm{~m} / \mathrm{s}$ ) STV2 rotoriumi būtų galima generuoti $736 \mathrm{Wh}$ energijos. 


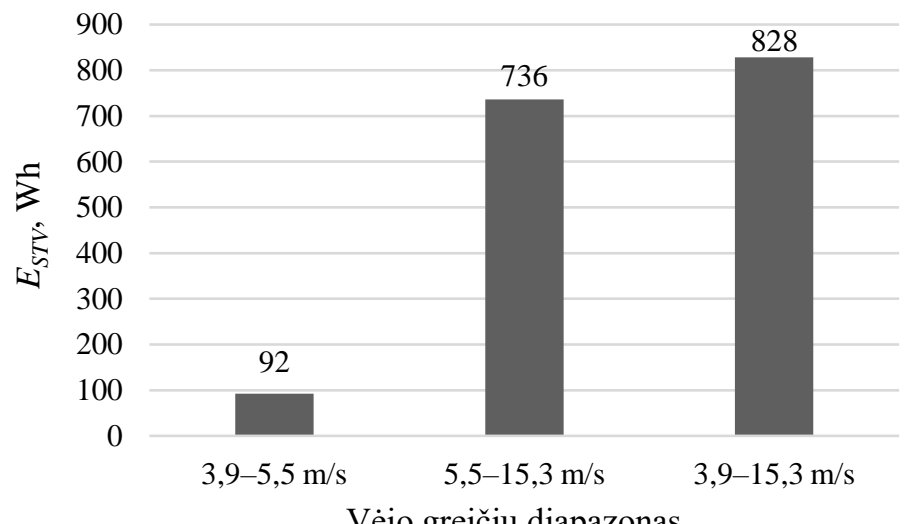

Vèjo greičių diapazonas

3.20 pav. Metinis STV2 akumuliuotos energijos potencialas

Fig. 3.20. Annual RTV2 accumulated energy potential

\subsubsection{Hibridinio vèdinimo funkcionalumo padidinimo teorinio skaičiavimo rezultatai}

Prieš pristatant funkcionalumo padidinimo skaičiavimus reikalinga įvertinti STV iprasto veikimo rezultatus. 3.21 paveiksle pateikiamas STV2 vidutinis ištraukiamo oro srauto kitimas metų laikotarpyje.

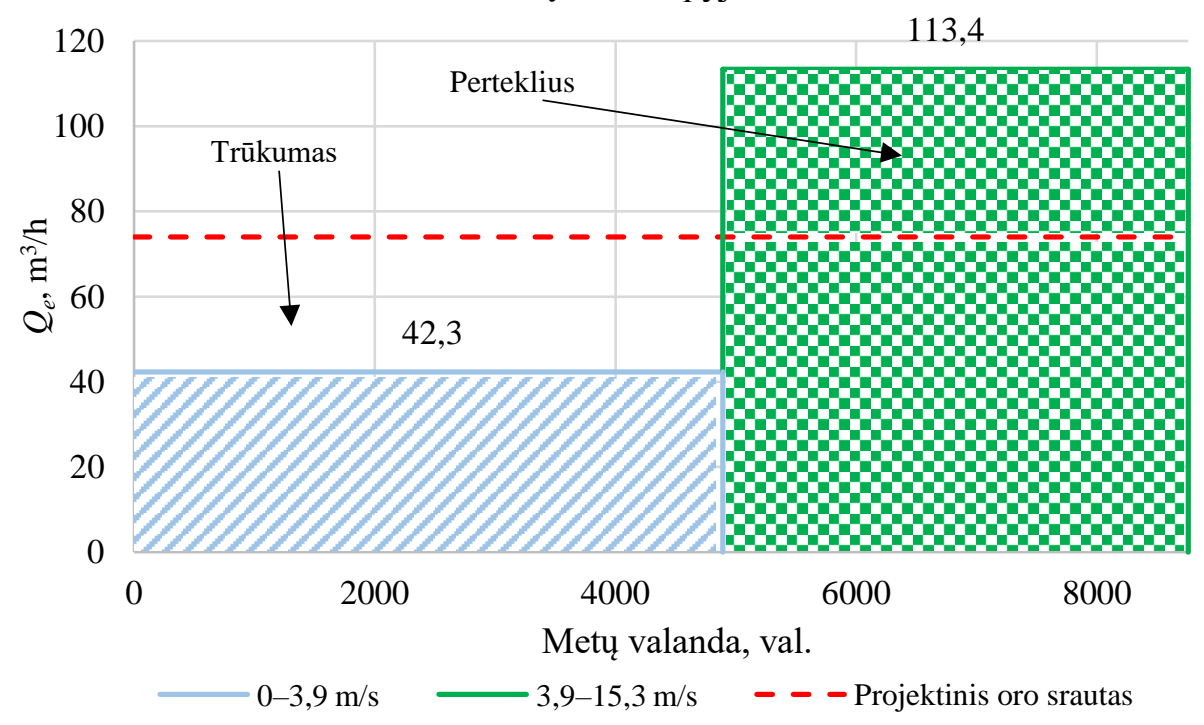

3.21 pav. Vidutinis ištraukiamo oro srauto pasiskirstymas esant ịprastam STV2 veikimui

Fig. 3.21. Average extracted airflow distribution under regular RTV2 operation 
Pagal pateiktus skaičiavimų rezultatus matoma, jog vejo greičiui esant 0-3,9 $\mathrm{m} / \mathrm{s}$ diapazone, ịrenginys veikdamas ịprastu režimu vidutiniškai gali ištraukti apie $42,3 \mathrm{~m}^{3} / \mathrm{h}$ oro srauto. Ivvertinus skirtumą tarp projektinio oro srauto nustatyta, kad šiuo laikotarpiu vidutiniškai trūksta apie $43 \%\left(31,7 \mathrm{~m}^{3} / \mathrm{h}\right)$ oro srauto. Bendru atveju šios įrenginio veikimo sąlygos per metus sudaro apie $57 \%$ laiko.

Likusią $43 \%$ laiko dali STV veikia užtikrindamas projektinị oro srautą, tačiau tuo pačiu yra laikotarpių kuomet susidaro ištraukiamo oro srauto perteklius. Apskaičiavus matoma, kad šiuo laikotarpiu STV vidutiniškai ištraukia apie $113,4 \mathrm{~m}^{3} / \mathrm{h}$ oro srauto. Lyginant su projektiniu oro srautu matoma, kad susidaro apie $53 \%\left(39,7 \mathrm{~m}^{3} / \mathrm{h}\right)$ perteklius.

Remiantis šiais vidutinio ištraukiamo oro srauto skaičiavimo rezultatais galima teigti, jog tiriamasis STV turi potencialo funkcionalumo didinimui. Šiuo atveju pristatant teorinius funkcionalumo padidinimo rezultatus priimama, jog visa STV rotoriumi generuojama galia bus perduodama ị elektros akumuliatorių. Akumuliuota elektros energija bus naudojama laikotarpiu kuomet ištraukiamas oro srautas bus mažesnis nei projektinis. Skaičiavimuose numatyta, kad akumuliuota energija elektros varikliu bus perduodama STV rotoriui ir tokiu būdu bus padidinamas ištraukiamas oro srautas.

Apskaičiavus nustatyta, jog siekiant ištraukti projektini oro debitą, STV2 įtekejjimo angoje oro greitis turi būti $v_{e}=1,88 \mathrm{~m} / \mathrm{s}$. Be to, priimama, jog elektros varikliui sukant STV rotorių, ištraukiamo oro srautui panaudojama tik dalis gautos energijos. Tai priimama atsižvelgiant ị kintantị sistemos veikimo darbo tašką ir tuo pačiu kintantį rotoriui suteiktos energijos naudojimo efektyvumą. Šiuo atveju tokio elektra varomo STV efektyvumas priimamas vidutinis ir jo verte nustatoma remiantis 2.17 paveiksle pateiktais skaičiavimo rezultatais. Analizuojamu atveju elektra varomo STV2 vidutinis efektyvumas laikomas $\eta_{r}=0,07$. 3.24 lygčiai pritaikius efektyvumo koeficientą, reikiama galia projektiniam oro srauto ištraukimui apskaičiuojama:

$$
\dot{E}_{Q r}=\frac{\dot{Q}_{e r} \cdot \Delta P_{t e}}{\eta_{r}}=\frac{\dot{Q}_{e r} \cdot \xi \cdot \rho_{a} \cdot v_{e}^{2}}{2 \cdot \eta_{r}} .
$$

Šia lygtimi apskaičiuota, jog STV2 rotorių sukant elektros varikliu, projektiniam oro debitui ištraukti reikalinga apie $0,82 \mathrm{~W}$ elektros galia. Toliau esančiame 3.22 paveiksle pateikiami skaičiavimo rezultatai kuomet STV rotoriumi atliekamas energijos akumuliavimas. 


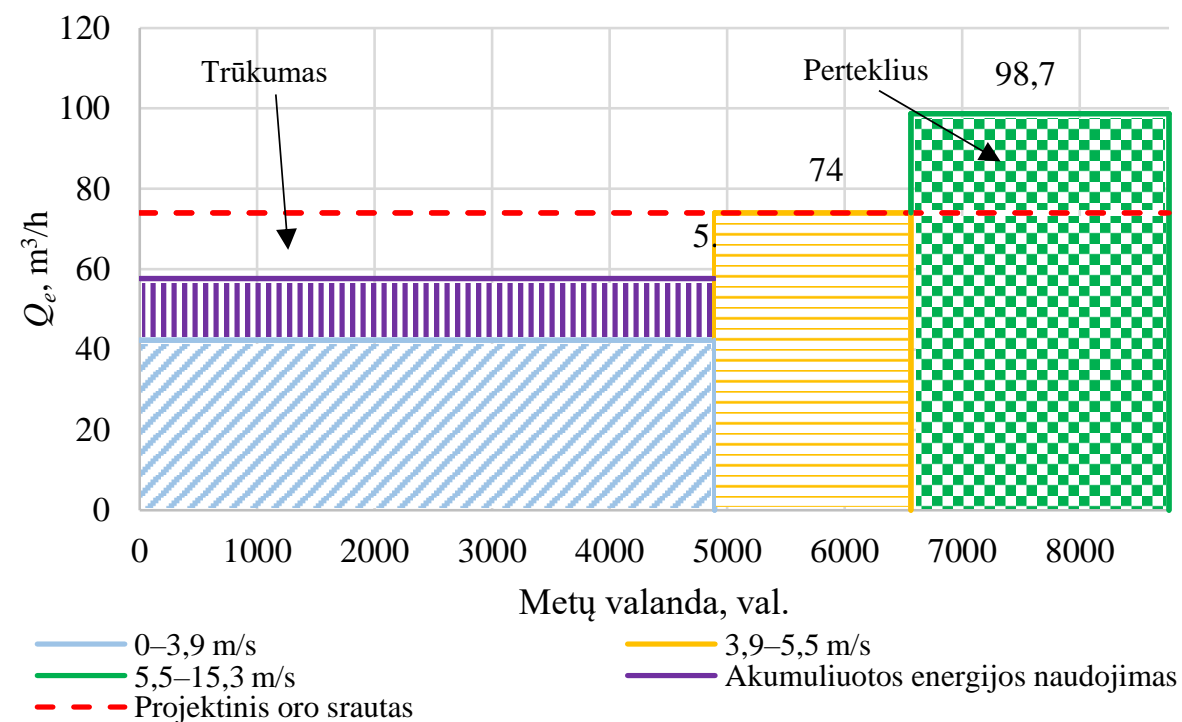

3.22 pav. Vidutinis ištraukiamo oro srauto pasiskirstymas naudojant akumuliuotą energiją

Fig. 3.22. Average extracted airflow distribution while using accumulated energy

Atliekant šiuos skaičiavimus priimama, jog šioje teorinejje hibridinio vėdinimo sistemoje bus panaudotas visas 3.19 paveiksle nustatytas metinis akumuliuotos energijos potencialas. Analizuojant šios sistemos skaičiavimų rezultatus matoma, jog energijos akumuliavimo metu vidutinis ištraukiamo oro srauto pasiskirstymas skiriasi nuo ịprasto STV veikimo. Vejjo greičiui esant $3,9-5,5 \mathrm{~m} / \mathrm{s}$ diapazone, įrenginys veikdamas dalinio apkrovimo metu ištraukia projektini $74 \mathrm{~m}^{3} / \mathrm{h}$ oro srautą. Esant didesniam nei projektiniam vejjo greičiui, atliekamas elektros generavimas su maksimaliu STV rotoriaus apkrovimu. STV2 veikiant šiomis sąlygomis, vidutinis ištraukiamas oro srautas būtų apie $98,7 \mathrm{~m}^{3} / \mathrm{h}$. Lyginant su projektiniu oro srautu matoma, kad susidaro apie $33 \%\left(24,7 \mathrm{~m}^{3} / \mathrm{h}\right)$ perteklius. Tuo tarpu palyginus su iprastomis STV veikimo sąlygomis, šis perteklius yra apie $20 \%$ mažesnis bei jo trukmè apie $19 \%$ trumpesnè.

Likusią $57 \%$ laiko dali STV veikia kombinuotai. Vèjo greičiui nesiekiant $3,9 \mathrm{~m} / \mathrm{s}$ ištraukiamas oro srautas būtų padidinamas naudojant sukauptą elektros energiją, kuria sukamas STV rotorius. Skaičiavimų metu nustatyta, jog esant tokioms veikimo sąlygoms, šiuo laikotarpiu STV vidutinis ištraukiamas oro srautas galètų padidèti apie $36 \%\left(15,4 \mathrm{~m}^{3} / \mathrm{h}\right)$.

3.23 paveiksle pateikiami skaičiavimo rezultatai rodantys metinio ištraukiamo oro srauto poreikio užtikrinimą. 


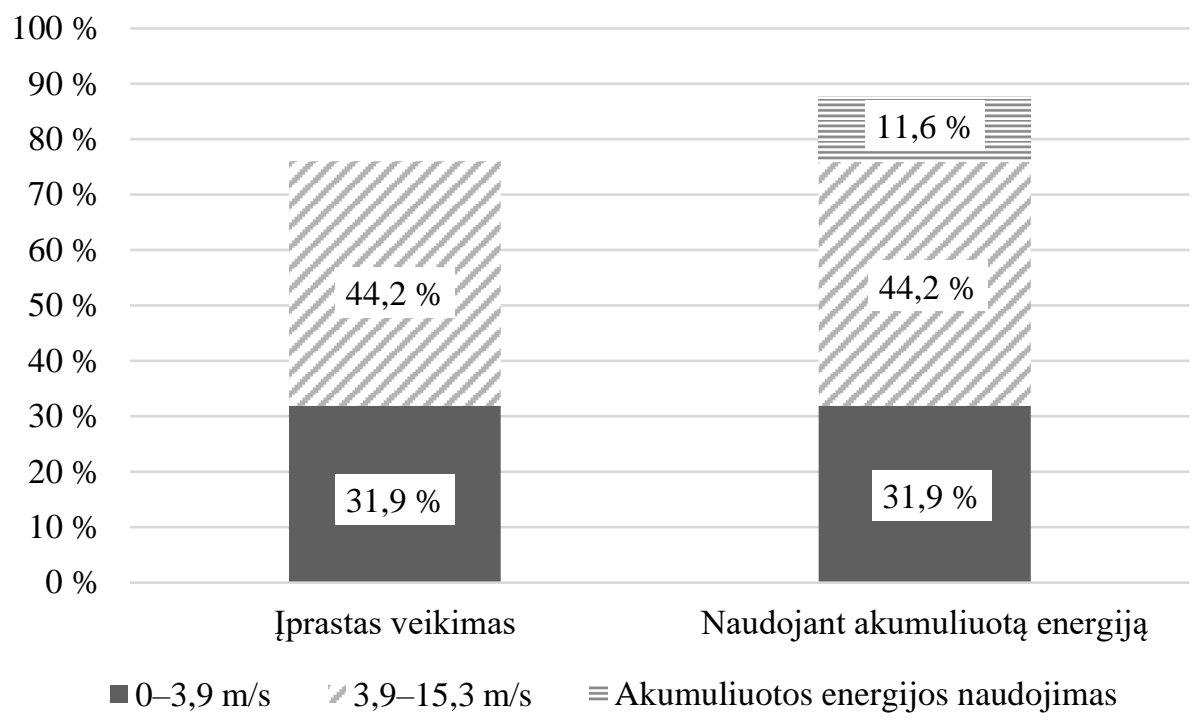

3.23 pav. Metinio ištraukiamo oro srauto poreikio užtikrinimo palyginimas

Fig. 3.23. Comparison of annual extracted airflow demand fulfillment

Pateiktas grafikas suskirstytas ị du stulpelius. Pirmasis stulpelis rodo metinio ištraukiamo oro užtikrinimą esant iprastam STV veikimui, o antrasis STV naudojant akumuliuotą energiją. Vertinant skaičiavimų duomenis nustatyta, kad 0-3,9 m/s vejjo greičio diapazone, STV2 veikdamas tik nuo vejo srauto gali užtikrinti $31,9 \%$ viso reikalingo metinio oro srauto. Tuo tarpu, esant didesniam nei $3,9 \mathrm{~m} / \mathrm{s}$ projektiniam vèjo greičiui, abiem veikimo režimais šiuo laikotarpiu užtikrinama 44,2 \% viso reikalingo metinio oro srauto. Sudejjus šiuos rezultatus matoma, kad STV veikdamas tik nuo vejjo srauto gali užtikrinti $76,1 \%$ metinio poreikio.

Akumuliuotą energiją naudojant STV2 rotoriaus sukimui metini vėdinimo funkcionalumą būtų galima padidinti apie $11,6 \%$. Bendru atveju tokia hibridinio vėdinimo sistema leistų užtikrinti apie $87,7 \%$ metinio poreikio. Kita vertus, net ir šiuo atveju, STV2 veikdamas tokiu režimu tam tikrais laikotarpiais ištraukia didesnį oro srautą nei reikalinga. Dèl šios priežasties, galimas dar didesnis STV funkcionalumo didinimas taikant ši įrengini didesnio ploto patalpose, ar ieškant kitų sprendimų leidžiančių efektyviau paskirstyti ištraukiamą oro srautą. 


\subsubsection{Akumuliuotos vèjo energijos naudojimo galimybès hibridinèje vèdinimo sistemoje}

Vertinant mokslines publikacijas ir rinkoje egzistuojančias hibridinio vėdinimo sistemas matoma, kad dažniausiai pasirenkami sprendimai su saulès elementais, arba tiesioginiu STV taikymu elektros generavimui. Šiame skyriuje pristatomas STV taikymo hibridineje vėdinimo sistemoje pavyzdys akumuliavimui pasitelkiant suspaustą orą. Šiuo atveju nagrinèjamas patentuotas išradimas, kurio veikimas paremtas integruojant oro talpyklą (Martinaitis et al., 2019). Toliau esančiame 3.24 paveiksle pateikiama tokio išradimo principinio veikimo schema.

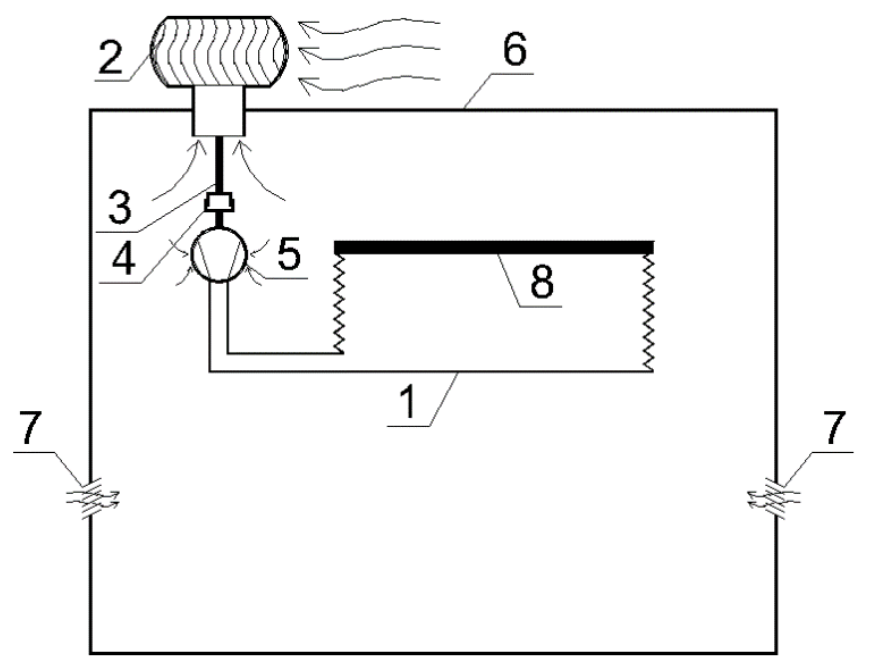

3.24 pav. Turbininio ventiliatoriaus funkcionalumo tobulinimo pavyzdys taikant oro talpyklą (Martinaitis et al., 2019)

Fig. 3.24. An example of turbine ventilator functionality development with integrated air storage (Martinaitis et al., 2019)

Žymèjimai schemoje: 1 - izobarinė oro talpykla; 2 - stoginis turbininis ventiliatorius (STV); 3 - velenas; ašis jungianti STV ir sankabą, 4 - sankaba; 5 reversinis kompresorius; 6 - vėdinama patalpa; 7 - pastato oro įtekejjimo angos; 8 - izobarinès oro talpyklos svarmuo.

Vejjo srautui sukant STV, pastate vyksta oro ištraukimas, o šviežias oras patenka pro pastate esančias angas (atviri langai, durys, angos ir kt.). Susidarius sąlygoms, kuomet turbininis ventiliatorius sukasi greičiau ir traukia didesni oro debitą nei reikia patalpoje - sankaba sujungiamas turbininis ventiliatoriaus ir reversinio kompresoriaus ašis. Tokiu būdu turbininio ventiliatoriaus sukimo energija perduodama kompresoriui. Reversinis kompresorius šiuo atveju siurbia 
orą iš patalpos (ar kitos aplinkos) ir kurdamas padidintą oro slègimą tiekia ši orą i izobarinę oro talpyklą.

Izobarinès oro talpyklos atveju, kai kompresorius slegia orą i talpyklą, talpykla keičia savo tūrị, o oras tiekiamas tol, kol talpykla pasiekia nustatytą ribinị tūrį. Tokiu būdu, slegiant orą ị talpyklą sukaupiama potencinè energija.

Susidarius sąlygoms, kai vèjas dèl sumažèjusio greičio nepakankamai ar visiškai nesuka stoginio STV, o pastate išlieka vėdinimo poreikis, kompresorius pradeda išleidinėti suslègtą orą iš oro talpyklos. Oras išleidžiamas iš talpyklos suka kompresoriaus ašị, kuri per sankabą sujungta su STV. Tokiu būdu iš talpyklos išleidžiamas oras suka STV ir atliekamas pastato vėdinimas.

Pristatytas išradimas su izobarine talpykla leidžia užtikrinti STV veikimą esant nepakankamoms vèjo greičio sąlygoms. Šiam techniniam sprendimui nereikia išorinès energijos bei elektros akumuliatorių, konstrukcija paprasta, sprendimas nesudetingai igyvendinamas. Šiuo atveju vietoj izobarinès talpyklos gali būti taikoma ir izochorinè talpykla. Tokios sistemos veiksmingumą lemtų kompresorius techninès galimybès kurti slègi esant tam tikriems STV sukimo parametrams.

\subsection{Trečiojo skyriaus išvados}

1. Parengus STV menamus turbinos, ežektoriaus ir ventiliatoriaus komponentus integruojantic veikimo termodinamini modelį, ji susiejus su eksperimentiniais tyrimais bei prièmus modeliui reikalingas prielaidas ir izoentropinio efektyvumo koeficientus, nustatyta, kad vejo srautas rotoriaus sukimui sunaudoja nuo 2,9\% iki 9,1 \% savo teorinès galios. Šiuo atveju efektyviausiai vejjo energija išnaudojama STV2 rotoriuje (mentès vertikaliai tiesios), o blogiausiai STV1 rotoriuje (mentès lenktos vertikalios ašies kryptimi). Tyrimai, rodo kad rotoriaus geometrinès savybès lemia tai, kad dalis pučiamo vėjo srauto atsiskiria nuo jo ir i STV vidų patekęs mažesnis vèjo srautas toliau dalyvauja ežekcijos procese.

2. Vertinant maksimalų vejjo srauto energijos panaudojimą pagal Betzo kriterijaus ribą, termodinaminiu modeliu nustatyta, kad analizuojamų STV atveju teorinis maksimalus siurbiamo oro srautas gali būti didesnis daugiau nei 2 kartus. Šiuo atveju bendras vèjo energijos vèjo srauto energijos naudojimo efektyvumas STV1, STV2 bei STV3 atitinkamai siekia $18,1 \%, 25,7 \%$ bei $21,2 \%$.

3. Analizei pasirinkus $68,5 \mathrm{~m}^{2}$ ploto hipotetini sandèliavimo paskirties pastatą Vilniaus mieste, STV2 per metus iš viso galètų akumuliuoti apie $828 \mathrm{Wh}$ perteklinès vėjo energijos. Esant ịprastam STV2 veikimui, įrenginys užtikrintų $76,1 \%$ metinio védinimo poreikio. STV2 pritaikius elektros energijos akumuliavimui ir ją naudojant įrenginio nepakankamo veikimo metu, teoriškai 
metinį vẻdinimo funkcionalumą galima padidinti apie 11,6\%. Tokia hibridinė sistema leistų užtikrinti apie 87,7 \% metinio vėdinimo poreikio.

4. Siekiant padidinti STV funkcionalumą, įrenginys gali būti naudojamas hibridinio vėdinimo sistemoje. Hibridiniam védinimui pasirinkus patentuotą sprendimą su oro talpykla galima užtikrinti STV veikimą esant nepakankamoms vèjo greičio sąlygoms. Tokiu būdu būtų išvengiamas elektros akumuliatorių ir išorinių energijos šaltinių poreikis. 


\section{Bendrosios išvados}

1. Eksperimentiškai nustatyta, jog STV ištraukiamas oro srautas ženkliai priklauso nuo vejo greičio, statinio slègio vėdinamoje patalpoje ir išorejje skirtumo, aerodinaminių STV savybių. Kompleksiškai vertinant vejjo greičių ir patalpos statinio slègio kitimą, geriausią ištraukiamo oro rezultatą pasiekia STV su vertikalios ašies kryptimi tiesiomis mentėmis (STV2). Tyrimų metu sudarius sąlygas vèjo srauto įsiurbimui pastebèta, kad bandyti ịrenginiai sumažina ìsiurbiamo vejjo srauto kieki nuo $25 \%$ iki $55 \%$ lyginant su atviru ortakiu. Vertinant STV maksimalios generuojamos galios ir oro siurbimo efektyvumus nustatyta, kad tokiu įrenginiu generuojamos galios efektyvumas siekia nuo $4 \%$ iki $8 \%$, o siurbimo efektyvumas nuo $12 \%$ iki $22 \%$.

2. Remiantis eksperimentinių tyrimų rezultatais ir STV veikimo principu nustatyta, kad STV sieja struktūrinis ir sąveikinis ryšys su kitais aerodinaminiais įrenginiais. STV sąveikaujančių oro srautų procesų analizei ir i̇renginio efektyvumo tyrimams gali būti taikoma trikomponente irenginio veikimo koncepcija, kuri išreikšta termodinaminiu modeliu. Toks trikomponentis STV susideda iš menamų turbinos, ežektoriaus ir ventiliatoriaus komponentų.

3. Parengtas STV menamus turbinos, ežektoriaus ir ventiliatoriaus komponentus integruojantis termodinaminis modelis šių tyrimų apimtyje leidžia įvertinti STV sąveikaujančių srautinių procesų poveikị įrenginio funkcionalumui, efektyvumui bei tobulinimo potencialui. Modeli susiejus su eksperimentiniais 
tyrimais bei prièmus reikalingas prielaidas nustatyta, kad analizuojamų STV atveju vejo srautas rotoriaus sukimui sunaudoja nuo 2,9\% iki 9,1\% savo teorinès galios. Termodinaminiu modeliu nustatyta, kad teorinis maksimalus siurbiamas oro srautas gali būti bent dvigubai didesnis.

4. Remiantis ịvairialypiais STV eksperimentiniais tyrimais ir statistiniais metinio vejo greičio kitimo duomenimis parengtas STV termodinaminis modelis leido ịvertinti STV ištraukiamo oro srautą bei energijos akumuliavimo potencialą hibridinèje vėdinimo sistemoje, atskleisti galimybę padidinti kintančią vejjo energiją naudojančių hibridinių vėdinimo sistemų funkcionalumą. Analizei pasirinkus Vilniuje įrengtą STV2 hibridinio vẻdinimo sistemą nustatyta, kad toks sprendimas teoriškai galètų padidinti metinį vẻdinimo funkcionalumą apie $11,6 \%$. 


\section{Literatūra ir šaltiniai}

Acred, A., \& Hunt, G. R. (2013). Passive Ventilation in Multi-Storey Atrium Buildings: a First-Order Design Guide. 34th Annual AIVC Conference, September 2013.

Antonio, Y. M., Périlhon, C., Descombes, G., \& Chacoux, C. (2012). Thermodynamic modelling of an ejector with compressible flow by a one-dimensional approach. Entropy, 14(4), 599-613. https://doi.org/10.3390/e14040599

AS/NZS 4740:2000. (2000). Australian/New Zealand Standard. Natural ventilatorsClassification and performance (p. 46).

Bay, N. T., \& Phuong, H. (2012). Performance Testing and Comparison of A Turbine Ventilator, A Vent Column, and Their Combination Under Thermal Buoyancy and Wind Effects. Volume $6:(2003), 86-95$.

Čekanavičius, V., \& Murauskas, G. (2001). Statistika ir jos taikymai.

Chan, S. C., Che-Ani, A. I., \& Nik Ibrahim, N. L. (2013). Passive designs in sustaining natural ventilation in school office buildings in Seremban, Malaysia. International Journal of Sustainable Built Environment, 2(2), 172-182. https://doi.org/10.1016/j.ijsbe.2014.01.002

Chong, W. T., Wang, X. H., Wong, K. H., Mojumder, J. C., Poh, S. C., Saw, L. H., \& Lai, S. H. (2016). Performance assessment of a hybrid solar-wind-rain eco-roof system for buildings. Energy and Buildings, 127, 1028-1042. https://doi.org/10.1016/j.enbuild.2016.06.065

Chu, C. R., \& Wang, Y. W. (2010). The loss factors of building openings for wind-driven ventilation. Building and Environment, 45(10), 2273-2279. 
https://doi.org/10.1016/j.buildenv.2010.04.010

Dale, J. D., \& Ackerman, M. Y. (1993). Evaluation of the performance of attic turbine ventilators.

Darco. (2020). Rotowent dragon. https://plumbing4home.com/

Elmualim, A. A. (2006). Effect of damper and heat source on wind catcher natural ventilation performance. Energy and Buildings, 38(8), 939-948. https://doi.org/10.1016/j.enbuild.2005.11.004

Elwan, M., Rizk, A., \& El-Morsi, M. (2018). A Review on Wind - Driven Cross Ventilation Techniques Inside Single Rooms. International Journal of Scientific and Engineering Research, 6(October), 75 of 93.

EN 13141-5. (2004). EN 13141-5. Ventilation for buildings - Performance testing of components/products for residential ventilation - Part 5: Cowls and roof outlet terminal devices.

Farahani, A. S., Adam, N. M., \& Ariffin, M. K. A. (2010). Simulation of Airflow and Aerodynamic Forces Acting on a Rotating Turbine Ventilator Department of Mechanical and Manufacturing Engineering , University Putra Malaysia ,. 3(1), 159-170.

Faye C. McQuiston, Jerald D. Parker, J. D. S. (2005). Heating, Venti- lating and Air Conditioning: analysis and design (6th editio). John Wiley and Sons.

Freitas, A. W., Morais, P. G., \& Centre, S. I. (2014). Orthodynamometer for measurement of longitudinal and transverse loads in wind tunnel testing. July, 2213-2220.

Gill, B., Schr, F., Bauer, A., \& Simon, M. (2021). Energy Research \& Social Science When energy efficiency goes out the window: How highly insulated buildings contribute to energy-intensive ventilation practices in Germany. 72(April 2020). https://doi.org/10.1016/j.erss.2020.101888

Han, D. H., Kim, S., Choi, J. H., Kim, Y. S., Chung, H. S., Jeong, H., Watjanatepin, N., Ruangpattanawiwat, C., \& Choi, S. H. (2018). Experimental study on thermal buoyancyinduced natural ventilation. Energy and Buildings, 177, 1-11. https://doi.org/10.1016/j.enbuild.2018.07.046

HASEC. (2007). Wing Jetter System: An Epoch-making Ventilator Achieved by Application of Wing Theory.

Havens, P. (2004). A combined fan and wind turbine model for attic turbine ventilators. Energy Efficient and Healthy Buildings, ARE318-E.

Haw, L. C., Saadatian, O., Sulaiman, M. Y., Mat, S., \& Sopian, K. (2012). Empirical study of a wind-induced natural ventilation tower under hot and humid climatic conditions. Energy \& Buildings, 52, 28-38. https://doi.org/10.1016/j.enbuild.2012.05.016

He, S., Li, Y., \& Wang, R. Z. (2009). Progress of mathematical modeling on ejectors. Renewable and Sustainable Energy Reviews, 13(8), 1760-1780. https://doi.org/10.1016/j.rser.2008.09.032

Horan, J. M., \& Finn, D. P. (2008). Sensitivity of air change rates in a naturally ventilated atrium space subject to variations in external wind speed and direction. Energy and Buildings, 40(8), 1577-1585. https://doi.org/10.1016/j.enbuild.2008.02.013 
Ismail, M., \& Abdul Rahman, A. M. (2010). Comparison of different hybrid turbine ventilator (HTV) application strategies to improve the indoor thermal comfort. International Journal of Environmental Research, 4(2), 297-308. https://doi.org/10.22059/ijer.2010.22

Ismail, Mazran, \& Abdul Rahman, A. M. (2012). Rooftop Turbine Ventilator: A Review and Update. Journal of Sustainable Development, 5(5), 121-131. https://doi.org/10.5539/jsd.v5n5p121

Izadyar, N., Miller, W., Rismanchi, B., \& Garcia-Hansen, V. (2020). Impacts of façade openings' geometry on natural ventilation and occupants' perception: A review. Building $\begin{array}{llll}\text { and } \quad \text { Environment, } & \text { 2019), } & 106613 .\end{array}$ https://doi.org/10.1016/j.buildenv.2019.106613

Jomehzadeh, F., Hussen, H. M., Calautit, J. K., Nejat, P., \& Ferwati, M. S. (2020). Natural ventilation by windcatcher (Badgir): A review on the impacts of geometry, microclimate and macroclimate. Energy and Buildings, 226, 110396. https://doi.org/10.1016/j.enbuild.2020.110396

Jones, B. M., Cook, M. J., Fitzgerald, S. D., \& Iddon, C. R. (2016). A review of ventilation opening area terminology. Energy and Buildings, 118, 249-258. https://doi.org/10.1016/j.enbuild.2016.02.053

Karakatsanis, C., Bahadori, M. N., \& Vickery, B. J. (1986). Evaluation of pressure coefficients and estimation of air flow rates in buildings employing wind towers. https://doi.org/10.1016/b978-0-08-033177-5.50152-6

Keenan, J. H., Neumann, E. P. (1942). A simple air ejector. ASME Journal of Applied Mechanics, A75 A81.

Keenan J, Neumann E, L. F. (1950). An investigation of ejector design by analysis and experiment. Journal of Applied Mechanics, 17, 299.

Khan, N., Su, Y., \& Riffat, S. B. (2008). A review on wind driven ventilation techniques. Energy and Buildings, 40(8), 1586-1604. https://doi.org/10.1016/j.enbuild.2008.02.015

Khan, N., Su, Y. Y., Riffat, S. B., \& Biggs, C. (2008). Performance testing and comparison of turbine ventilators. Renewable Energy, 33(11), 2441-2447. https://doi.org/10.1016/j.renene.2008.01.016

Kitzberger, T., Kotik, J., Schmöllerl, M., \& Pröll, T. (2018). Energy savings through implementation of a multi-state Time Control Program (TCP) in demand-controlled ventilation of commercial buildings. Energy and Buildings, 164, 33-47. https://doi.org/10.1016/j.enbuild.2017.12.058

Lai, C. M. (2003). Experiments on the ventilation efficiency of turbine ventilators used for building and factory ventilation. Energy and Buildings, 35(9), 927-932. https://doi.org/10.1016/S0378-7788(03)00024-0

Lai, C. M. (2006). Prototype development of the rooftop turbine ventilator powered by hybrid wind and photovoltaic energy. Energy and Buildings, 38(3), 174-180. https://doi.org/10.1016/j.enbuild.2005.06.004

Lien, J. (2002). Wind Driven Ventilation for Enhanced Indoor Air Quality. Intechopen.Com. https://doi.org/10.5772/1030 
Lien, S. T. J., \& Ahmed, N. A. (2010). Numerical simulation of rooftop ventilator flow. Building and Environment, 45(8), 1808-1815. https://doi.org/10.1016/j.buildenv.2010.02.009

Lien, S. T. J., \& Ahmed, N. A. (2011). Effect of inclined roof on the airflow associated with a wind driven turbine ventilator. Energy and Buildings, 43(2-3), 358-365. https://doi.org/10.1016/j.enbuild.2010.09.027

Liu, J., Wang, L., Jia, L., Wang, X. (2018). Thermodynamic modeling and sensitivity analysis of ejector in refrigeration system. International Journal of Heat and Mass Transfer, 126.

Liu, F. (2014). Review on Ejector Efficiencies in Various Ejector Systems. 15th International Refrigeration and Air Conditioning Conference, 1533, 1-10.

Liu, Fang, \& Groll, E. A. (2013). Study of ejector efficiencies in refrigeration cycles. Applied Thermal Engineering, 360-370. https://doi.org/10.1016/j.applthermaleng.2012.12.001

Liu Li, C. M. M. (2007). The assessment of the performance of a windcatcher system using computational fluid dynamics. Building and Environment, 42, 1135-1141.

Lomas, K. J., \& Ji, Y. (2009). Resilience of naturally ventilated buildings to climate change: Advanced natural ventilation and hospital wards. Energy and Buildings, 41(6), 629-653. https://doi.org/10.1016/j.enbuild.2009.01.001

Lukiantchuki, M. A., Prata Shimomura, A., Marques da Silva, F., \& Caram, R. M. (2020). Wind tunnel and CFD analysis of wind-induced natural ventilation in sheds roof building: impact of alignment and distance between sheds. International Journal of Ventilation, 19(2), 141-162. https://doi.org/10.1080/14733315.2019.1615219

Mak, C. M., Niu, J. L., Lee, C. T., \& Chan, K. F. (2007). A numerical simulation of wing walls using computational fluid dynamics. Energy and Buildings, 39(9), 995-1002. https://doi.org/10.1016/j.enbuild.2006.10.012

Monodraught. (2020). Windcatcher: Harnessing the environment for building ventilation. https://www.monodraught.com/products/natural-ventilation/windcatcher-classic

Moosavi, L., Mahyuddin, N., Ab Ghafar, N., \& Azzam Ismail, M. (2014). Thermal performance of atria: An overview of natural ventilation effective designs. Renewable and Sustainable Energy Reviews, 34, 654-670. https://doi.org/10.1016/j.rser.2014.02.035

Nouanégué, H. F., Alandji, L. R., \& Bilgen, E. (2008). Numerical study of solar-wind tower systems for ventilation of dwellings. Renewable Energy, 33(3), 434-443. https://doi.org/10.1016/j.renene.2007.03.001

Park, J., Sun, X., Choi, J. Il, \& Rhee, G. H. (2017). Effect of wind and buoyancy interaction on single-sided ventilation in a building. Journal of Wind Engineering and Industrial Aerodynamics, $\quad$ 171(July), 380-389. https://doi.org/10.1016/j.jweia.2017.10.016

Peters, C. A. (2001). Statistics for Analysis of Experimental Data. In Environmental Engineering Processes Laboratory Manual, Princeton University. https://doi.org/10.1145/2901739.2901780

Pfeiffer, A., Dorer, V., \& Weber, A. (2008). Modelling of cowl performance in building 
simulation tools using experimental data and computational fluid dynamics. Building and Environment, 43(8), 1361-1372. https://doi.org/10.1016/j.buildenv.2007.01.038

Piselli, C., Prabhakar, M., de Gracia, A., Saffari, M., Pisello, A. L., \& Cabeza, L. F. (2020). Optimal control of natural ventilation as passive cooling strategy for improving the energy performance of building envelope with PCM integration. Renewable Energy, 162, 171181. https://doi.org/10.1016/j.renene.2020.07.043

Pourshab, N., Tehrani, M. D., Toghraie, D., \& Rostami, S. (2020). Application of double glazed façades with horizontal and vertical louvers to increase natural air flow in office buildings. Energy, 200, 117486. https://doi.org/10.1016/j.energy.2020.117486

Rashid, D. M. H., \& Ahmed, N. A. (2003). Study of aerodynamic forces on a rotating wind driven ventilator. Wind Engineering, 27(1), 63-72. https://doi.org/10.1260/030952403321833770

Ravel, A. (1998). Testing of Hurricane Ventilators Vs. Spherical Vane Ventilators.pdf.

Revel, a, \& Huynh, B. P. (2007). Characterising Roof Ventilators. December 2004, 1-4. Sarevski, V.N., Sarevski, M. N. (2014). Preliminary study of a novel R718 refrigeration cycle with single stage centrifugal compressor and two-phase ejector. International Journal of Refrigeration, 40, 435-449.

Šarevski, V. N., \& Šarevski, M. N. (2012). Energy efficiency of the thermocompression refrigerating and heat pump systems. International Journal of Refrigeration, 35(4), 10671079. https://doi.org/10.1016/j.ijrefrig.2011.12.002

Savonius, O. (1932). Undersokning av Sughuvar och Rotor-Ventiatorer. Sartryck Ur Teknisk Tidskrift, Mekanik 9.

Shinde, R., Lavhale, V., Nair, A., Pawar, S., \& Mahajan, R. (2016). Generation of Electric Power using Turbo Ventilators. 6(6), 89-93.

Shun, S., \& Ahmed, N. A. (2008). Utilizing wind and solar energy as power sources for a hybrid building ventilation device. Renewable Energy, 33(6), 1392-1397. https://doi.org/10.1016/j.renene.2007.07.017

Sik, Y., Hun, D., Chung, H., Jeong, H., \& Choi, S. (2017). Experimental study on Venturitype natural ventilator. Energy \& Buildings, 139, 232-241. https://doi.org/10.1016/j.enbuild.2017.01.016

Sun, X., Luo, D., Huang, D., \& Wu, G. (2012). Numerical study on coupling effects among multiple Savonius turbines. Journal of Renewable and Sustainable Energy, 4(5). https://doi.org/10.1063/1.4754438

Twidell, J. W., \& Weir, A. D. (2015). Renewable Energy Resources. https://doi.org/doi:10.4324/9781315766416

van Hooff, T., Blocken, B., Aanen, L., \& Bronsema, B. (2011). A venturi-shaped roof for wind-induced natural ventilation of buildings: Wind tunnel and CFD evaluation of different design configurations. Building and Environment, 46(9), 1797-1807. https://doi.org/10.1016/j.buildenv.2011.02.009

Varela-Boydo, C. A., \& Moya, S. L. (2020). Inlet extensions for wind towers to improve natural ventilation in buildings. Sustainable Cities and Society, 53(November 2019), 
101933. https://doi.org/10.1016/j.scs.2019.101933

Welsh, P. (1994). The testing and rating of terminals used on ventilation systems. 15th AIVC Conference, 371-380.

West, S. (2001). Improving the sustainable development of building stock by the implementation of energy efficient, climate control technologies. Building and Environment, 36(3), 281-289. https://doi.org/10.1016/S0360-1323(00)00007-X

Wills, D. R., Dance, E. W. G., \& Blench, G. T. (1959). Formes et performance d'aspiraterus statiques pour conduits d'extraction naturelle de gaz brulé. Station expérimentale du Conseil du Gaz à Londres.

Wu, W., Min, J., \& Malkawi, A. (2021). Simplified direct forcing approach for dynamic modeling of building natural ventilation. Building and Environment, 188(June 2020), 107509. https://doi.org/10.1016/j.buildenv.2020.107509

Yuan, J., \& Glicksman, L. R. (2008). Multiple steady states in combined buoyancy and wind driven natural ventilation: The conditions for multiple solutions and the critical point for initial conditions. Building and Environment, 43(1), 62-69. https://doi.org/10.1016/j.buildenv.2006.11.035

Zaki, A., Richards, P., \& Sharma, R. (2019). Analysis of airflow inside a two-sided wind catcher building. Journal of Wind Engineering and Industrial Aerodynamics, 190(August 2018), 71-82. https://doi.org/10.1016/j.jweia.2019.04.007 


\section{Autoriaus mokslinių publikacijų disertacijos tema sąrašas}

\section{Straipsniai recenzuojamuose mokslo žurnaluose}

Rimdžius, D., Bielskus, J., Streckienė, G., Motuzienė, V., \& Martinaitis, V. (2021). Operation analysis of the developed building ventilation system using turbofans and mechanical wind energy storage. Building and Environment (Clarivate Analytics Web of Science), 196. https://doi.org/10.1016/j.buildenv.2021.107703

Martinaitis, V., Rimdžius, D., Bielskus, J., Streckienè, G., \& Motuzienè, V. (2020). Preliminary comparison of the performance of thermodynamic models of the subsonic ejector and turbofan. Strojniski Vestnik/Journal of Mechanical Engineering (Clarivate Analytics Web of Science), 66 (5), 325-336. https://doi.org/10.5545/sv-jme.2019.6379

Rimdžius, D., \& Bielskus, J. (2018). Turboventiliatorių, veikiančių be vėjo srauto, eksperimentinis tyrimas. Mokslas - Lietuvos Ateitis: Aplinkos Inžinerija, 10, 1-5. https://doi.org/10.3846/mla.2018.3262

\section{Straipsniai kituose leidiniuose}

Streckienė, G., Bielskus, J., Rimdžius, D., Martinaitis, V., \& Motuzienè, V. (2021). Experimental Analysis of an Air Storage Tank in Wind Driven Ventilation System. E3S Web of Conferences. https://doi.org/10.1051/e3sconf/202123102003 
Rimdžius, D., Bielskus, J., Martinaitis, V., Motuzienè, V., \& Streckienè, G. (2018). Experimental Evaluation of Turbine Ventilators Performance under Different Test Conditions. E3S Web of Conferences. https://doi.org/10.1051/e3sconf/20186407003

Streckienė, G., Motuzienè, V., Rimdžius, D., Martinaitis, V., \& Bielskus, J. (2018). Simulation of Annual Functionality of Roof Turbine Ventilator. E3S Web of Conferences. https://doi.org/10.1051/e3sconf/20186407002

Sketerskis, M., Rimdžius, D., \& Martinaitis, V. (2018). Turboventiliatoriaus efektyvumo gerinimo tyrimas. 21-osios Lietuvos jaunuju mokslininku konferencijos „Mokslas Lietuvos ateitis “ temine konferencija. https://doi.org/10.3846/pinzs.2018.07

Januševičius, K., Bielskus, J., Martinaitis, V., Streckienė, G., \& Rimdžius, D. (2017). Expressing the building energy systems thermodynamic seasonal efficiency. 10th International Conference on Environmental Engineering, ICEE 2017, April, 27-28. https://doi.org/10.3846/enviro.2017.271

\section{Patentai}

Martinaitis V., Bielskus J., Motuzienė V., Streckienė G., \& Rimdžius D. (2021a). Device with a roof turbofan for extracting the air from a building having an air tank with a turbofan thereof and method of building ventilation with such device. European patent No. 0673422 B1. European Patent Office.

Martinaitis V., Bielskus J., Motuzienè V., Streckienė G., \& Rimdžius D. (2021b). Irenginys orui iš pastato traukti su stoginiu turboventiliatoriumi, turintis oro kaupyklą su kaupyklos turboventiliatoriumi ir pastato vėdinimo būdas naudojant tokị įrenginị. Patento numeris 6800. Lietuvos Respublikos valstybinis patentų biuras.

Martinaitis V., Rimdžius D., Bielskus J., Streckienė G., \& Motuzienė V. (2019). İrenginys orui iš pastato traukti su turboventiliatoriumi, turintis oro talpyklą ir pastato vèdinimo būdas naudojant toki įrenginị. Patento numeris 6613. Lietuvos Respublikos valstybinis patentų biuras. 


\section{Summary in English}

\section{Introduction}

\section{Formulation of the problem}

Electric ventilators used in modern buildings ventilation systems account for a large portion of the overall energy required for buildings. Reducing energy consumption requires looking for new solutions to ensure a high degree of ventilation system efficiency and the required quality of air. One possible option is using technology based on renewable energy. Renewable energy resources are becoming an intrinsic source of energy for modern technologies, yet nearly all of their forms have one essential flaw: they fail to provide a stable flow of energy to satisfy the needs. For this reason, many such systems are unable to guarantee the desired ventilation functionality.

Widespread method right now is wind-driven roof turbine ventilators (RTV). Review of prior research shows that there is a pronounced shortage of studies to offer a universal interpretation of the impact of airflow processes on the efficiency of turbine ventilators, as well as an absence of a universal model of operation of such devices. Analysis of studies of hybrid systems that increase the functionality of ventilation reveals that any efforts to improve said systems are limited to the addition of an electric ventilator or solar panels, without giving any regard to the effectiveness of turbine ventilators based on the season or looking into the potential for accumulating excess wind energy. 


\section{Relevance of the thesis}

The airflow processes inside turbine ventilators are complex, as a result, the quantitative and qualitative studies employed to measure their effectiveness and functionality involve a significant amount of time costs. The primary hypothesis of this thesis is that the processes taking place in turbine ventilators as such combine processes that occur inside wind turbines, ejectors and ventilators. It is elaborated further by building the concept of a thermodynamic model of operation of the device, to be used to measure the interaction of flow-based processes within said three components and apply it to improve turbine ventilators. The model built on the basis of this concept is tested through experimental research in a focused manner within the scope of this thesis.

To be able to make a quantitative comparison of devices within a broad range of operation, for the purposes of this thesis the characteristics of air extracted by wind-driven ventilators are determined not only for different wind speeds, but for varying conditions of the static environmental pressure as well. Furthermore, analysis of turbine ventilators involves tests of generated power and aerodynamic properties, a rarity in its own right.

An overview of hybrid ventilation systems points to efforts to find solutions to improve the functionality of ventilation when the wind flow is insufficient for the turbine ventilator to operate under nominal load. However, there is a shortage of research into the possibilities to accumulate excess wind energy in such systems. This thesis attempts to evaluate the potential of energy storage and usage to increase the functionality of ventilation.

\section{The object of research}

The object of this research is wind-driven roof turbine ventilators, their operation, effectiveness, and functionality.

\section{The aim of the thesis}

The aim of this thesis is to prepare a theoretical model of turbine ventilator operation based on experimentally determined mechanical and aerodynamic characteristics.

\section{The tasks of the thesis}

In order to achieve the aim of the thesis, the following objectives should be met:

1. Prepare and execute, based on the studies reviewed, an experimental research programme to structure the operating modes of the RTV into separate flow processes.

2. Carry out a quantitative and qualitative comparison of the experimental torque, rotation frequency, power, and airflow characteristics of different RTVs, determine their empiric equations and compare them with theoretical equations.

3. Propose, based on the results of experimental research, structural breakdown concept reflecting the RTV construction and flow processes to facilitate the development of a thermodynamic model of processes.

4. Design a thermodynamic model of the chosen RTV components and establish a valid link between the model and the results of experimental research. 
5. Evaluate the possibilities to improve the efficiency of the use of wind energy by the RTV based on stochastic wind variation during the year-cycle.

\section{Research methodology}

The experimental research presented herein was done at the laboratory of Vilnius Gediminas Technical University (Vilnius Tech) and Portugal's National Laboratory of Civil Engineering of (LNEC). The lab tests were carried out in wind tunnels based on the international RTV test standards EN 13141-5, AS/NZS 4740:2000 as well as experimental research ideas featured in scientific publications. Wind speeds, static pressures, RTV rotor loads were varied under different simulated conditions of operation. The results of the study were processed and compared using a systemic analysis that combines the statistical, dimensionless, thermodynamic, and other methods employed in the study.

The preparation of the thermodynamic concept of the model of RTV operation relied on thermodynamic analysis, and the process dependencies identified under a qualitative and quantitative method were grounded on experiment results. Calculation of annual indicators used wind speed data from the Meteonorm application.

\section{Scientific novelty of the thesis}

Over the course of writing this thesis, the following results new to mechanical engineering were obtained:

1. The experimental research applied an integral test method that allowed assessing the ventilation functionality, aerodynamic drag and power generated by three different RTVs tested. Empiric equations of characteristics were formulated for the devices tested.

2. The extracted airflows of two different wind energy deflectors and three RTVs under different wind speeds and static environmental pressure conditions were compared from a quantitative and qualitative standpoint, using a dimensionless analysis.

3. Having established a link between the results of experimental research, the thesis showcases the concept that integrates the operation of the wind-driven RTV ejector, turbine, and roof ventilator expressed as an integral thermodynamic model of airflow interaction. The model developed under this concept allows making a quantitative and qualitative assessment of the impact of the flow processes that interact while the RTV is in operation on the device's functionality, determining the efficiency and a theoretical potential for improvement.

4. Based on the experimental research results and the statistical data of annual wind speed variation, the theoretical potential of increasing the RTV extracted airflow, energy accumulation, and functionality in a hybrid ventilation system was appraised.

\section{Practical value of the research findings}

This work presents a multi-component concept of a wind driven RTV expressed as a thermodynamic model, which allows making a qualitative and quantitative assessment of the 
different flows affecting the RTV, evaluating their impact on the functionality of the device, identifying the efficiency and a theoretical potential for improvement. The results of the experimental research benefit the development of ventilation systems based on renewable wind energy and assessment of the effectiveness of such systems for the purposes of accumulating excess wind energy. The results of theoretical calculations and the approaches presented herein can be used to evaluate an increase in the functionality of ventilation.

\section{Defended statements}

1. The RTV functionality is heavily dependant on the static pressure conditions - that is why the choice of such devices should not be limited to just assessing their characteristics based on wind speed.

2. The integral thermodynamic RTV model expressed as a concept of structural breakdown of three components allows assessing the airflow interactions in wind driven RTVs as well as the possibilities to improve such devices.

3. A broad awareness of RTV characteristics allows assessing the possibilities to accumulate excess energy generated and increase the functionality of hybrid ventilation systems that use variable wind energy

\section{Approval of the research findings}

A total of 8 articles have been published on the subject of this dissertation: two of them in publications peer-reviewed in the Clarivate Analytics Web of Science databases with a citation index (Rimdžius et al., 2021; Martinaitis et al., 2020); four, in conference publications peer-reviewed in the Clarivate Analytics Proceedings database (Rimdžius et al., 2018; Streckienè et al., 2021; Streckienė et al., 2018; Januševičius et al., 2017); one, in publications of other international databases (Rimdžius \& Bielskus, 2018); one, in conference report materials (Sketerskis, Rimdžius, \& Martinaitis, 2018). One patent has been registered with the European Patent Bureau (Martinaitis et al., 2021). Another two patents have been registered with the State Patent Bureau of the Republic of Lithuania (Martinaitis et al., 2021, Martinaitis et al., 2019).

Three reports on the subject of this dissertation have been delivered at international conferences in Lithuania and in Germany:

- The $10^{\text {th }}$ International Conference 'Environmental Engineering' in Vilnius (Lithuania) in 2017;

- The $3^{\text {rd }}$ International Conference on Power and Renewable Energy (ICPRE 2018) in Berlin (Germany) in 2018 (two reports).

\section{The structure of the dissertation}

The thesis consists of the introduction, three chapters, general conclusions and three appendices.

The volume of the thesis is 129 pages excluding appendices. 76 numbered equations, 57 figures and 6 tables were used in the text. 73 literature sources were used when writing the thesis. 


\section{Review of the wind driven natural ventilation systems research}

Natural ventilation is a key factor when it comes to designing energy-efficient buildings. The process of natural ventilation is governed by two fundamental principles: the force of gravity and the wind driven movement of airflows (Haw et al., 2012; Jomehzadeh et al., 2020; Park et al., 2017). These forces of a different nature usually act at the same time and in some cases may travel in the opposite directions, or may act in synergy, boosting each other up. Wind driven ventilation depends on the wind speed, direction, the geometry of the building, the type of natural ventilation devices, and other factors (Chu \& Wang, 2010; van Hooff et al., 2011).

As a general rule, based on the principle of their operation, natural ventilation technologies may be categorised as passive and active (M. Ismail \& Abdul Rahman, 2010; J. Lien, 2002). Passive technologies often constitute the architectural solutions of the building, additional roof or wall-mounted structures and devices (Chan et al., 2013). These could be the atria, the wing wall, the wind tower, the double skin facade, the wind catcher, the deflector, the wing jetter, the Venturi-type natural ventilator, and so on (Acred \& Hunt, 2013; Elwan et al., 2018; Han et al., 2018; HASEC, 2007; Liu Li, 2007; Pfeiffer et al., 2008; Varela-Boydo \& Moya, 2020). Active wind driven ventilation technologies are solutions that under the effect of the wind flow or an additional source of energy, rotate or otherwise move to perform mechanical work (J. Lien, 2002). One of the most frequently occurring pieces of active natural ventilation hardware is the roof turbine ventilator. The active natural ventilation that these devices perform directly depends on the wind flow. These devices also include hybrid turbine ventilators that have additional sources of energy and a built-in air extraction ventilator.

Even though turbine ventilators may seem easy to design, the airflow processes that take place inside the turbine ventilator are complex, requiring a wide application of experimental research (S. T. J. Lien \& Ahmed, 2010). An overview of scientific literature shows that RTV analysis often involves experimental research performed in wind tunnels. As often as not, the objective is to measure the variation of the air suction flow rate depending on the wind speed (Bay \& Phuong, 2012; Dale \& Ackerman, 1993; Khan, Su, Riffat, et al., 2008; Lai, 2003; Ravel, 1998; West, 2001). Research also aims to determine the dependence of the extracted airflow variation on the direction of wind (Dale \& Ackerman, 1993), looks into devices of varying sizes (West, 2001), analyses the impact of the cross-section area of the RTVs air inflow opening (Revel \& Huynh, 2007), the significance of the type and height of the blades (Khan, Su, \& Riffat, 2008; West, 2001), the effect of the roof slope (S. T. J. Lien \& Ahmed, 2011), and the aerodynamic forces that affect the device (Farahani et al., 2010; Rashid \& Ahmed, 2003). Studies of hybrid turbine ventilators involve testing devices with an extra electric ventilator devices that are capable of generating electricity (Shinde et al., 2016). Studies of computational fluid dynamics are usually employed to test different turbulence models and measure the extracted airflow (Farahani et al., 2010; Havens, 2004; S. T. J. Lien \& Ahmed, 2010, 2011)

Review of research endeavours has highlighted an absence of studies to address the interaction of airflows and the processes of energy transformation while the device is in operation. There is also a shortage of research to experimentally establish the aerody- 
namic, mechanical characteristics of turbine ventilators, analyse the efficiency and functionality of devices within a hybrid ventilation system. In a large volume of studies, RTVs are approached with numeric methods, yet the operation of these devices has never been described with theoretical models. Besides, not enough attention is being given to the potential of increasing the wind energy accumulation capacity and functionality of turbine ventilators in hybrid ventilation systems.

An overview of studies has showed that there is reason to carry out experimental research aimed at expressing the multi-component concept of the RTV as an integral thermodynamic model of airflow interaction and evaluating the potential of this device to accumulate wind energy to boost the functionality of the hybrid ventilation system.

\section{Mechanical and aerodynamic research of turbine ventilators}

When the RTV is in operation, the device is affected by the wind flow, the extracted airflow; plus, processes of these flows mixing are taking place, the rotor is spinning, and various aerodynamic forces and other phenomena come into play. This whole of occurrences is quite intricate; that is why developing a thermodynamic model of the turbine ventilator has to be preceded by a disclosure of the different individual processes affecting the RTV. For the purposes of this thesis, it is done with experimental research that gradually eliminates certain common factors. To reveal and experimentally check the multifaceted interaction of airflows in wind driven roof turbine ventilators, a special experimental research programme has been developed. The results of this experimental research programme are furthermore used to analyse the interactions of individual flow processes and to formulate the thermodynamic model of the device's operation on that basis.

Experimental research aims to measure the mechanical and aerodynamic characteristics, determine the impact different airflows have on the efficiency, effectiveness, and functionality. During research, RTVs are subjected to tests under different modes of operation: without the RTV; in the normal mode of RTV operation; with wind flow suction into the ventilated room; with the air extraction channel closed; with the RTV rotor blocked; with the RTV rotor under load; with the RTV rotor rotating driven by an electric motor. Depending on the mode of operation, test conditions are then varied as follows: operation in the absence of a wind flow; with the wind flow adjusted; with the RTV's air extraction channel closed; with the static pressure inside the ventilated room adjusted; with the tension of the RTV's rotor adjusted.

The research involves testing three turbine ventilators that have different constructions but the same principle of operation. The rotor construction in two of the ventilators consists of vertically arched blades, while the rotor of the third ventilator is made of vertically straight blades. For the purposes of comparing these devices with natural ventilation systems, an additional roof deflector has been selected. Figure S2.1 shows photographs, labels, and key measurements of the test devices. 


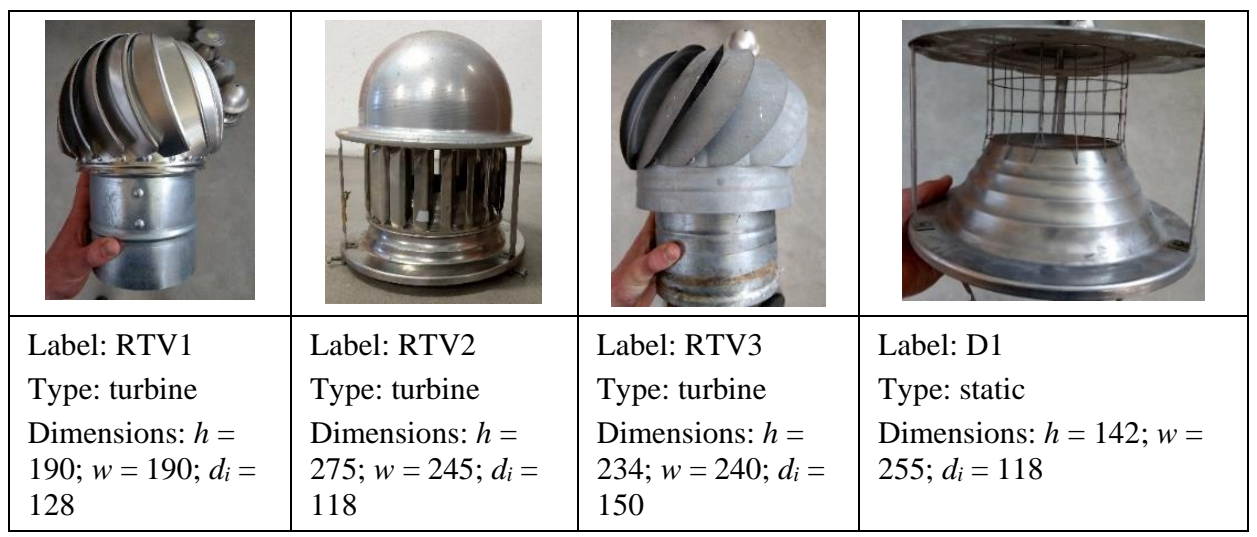

Fig. S2.1. Pictures of test devices, labels, and key dimensions

Explanation of dimensions: $h$ - the height of the device, mm; $w$ - the width of the device, $\mathrm{mm} ; d_{i}-$ the diameter of the extracted airflow opening, $\mathrm{mm}$.

In this case, the tests were done on three different types of stands. The main test stand was used to measure the extracted airflow and the power generated by the devices. A modified open-return wind tunnel with a special chamber to simulate the ventilated room was used for test purposes. Figure S2.2 shows the scheme of the experimental test stand at the LNEC.

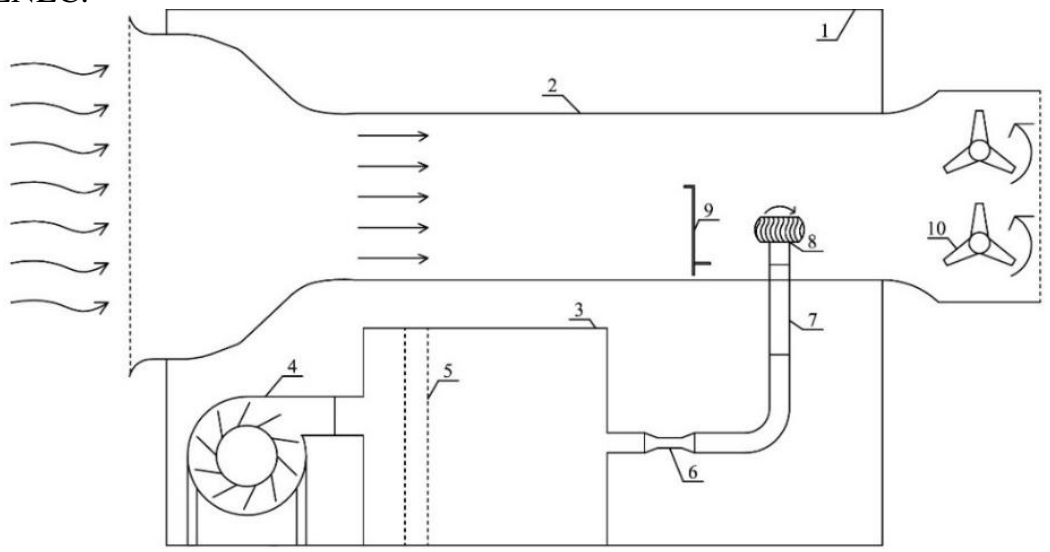

Fig. S2.2. LNEC experimental stand scheme

Explanation of figure S2.2: 1 - the test lab room; 2 - the open-return wind tunnel; 3 - the airflow stabilisation chamber; 4 - the ventilator that adjusts the static pressure in the ventilated room; 5 - the airflow stabilisation net; 6 - the extracted airflow meter; 7 the air extraction duct; 8 - the test device; 9 - the Pitot tube for measuring the airflow speed; 10 - wind tunnel ventilators. 
The test RTV is connected via the air duct to the airflow stabilisation chamber, its purpose being to simulate the ventilated room and to maintain the difference in static pressure between the inside and the outside at a level required for the test. For the purposes of the tests, wind speeds are adjusted in three stages: $2.7 \mathrm{~m} / \mathrm{s}, 5.6 \mathrm{~m} / \mathrm{s}$, and $9.2 \mathrm{~m} / \mathrm{s}$. The test stand is equipped with a Venturi-type meter to measure the extracted airflow. The function of the airflow stabilisation chamber is to compensate pressure losses and maintain the required pressure in the chamber that simulates the ventilated room. The rotation frequency of the turbine ventilators is measured during the tests with an Extech RPM33 optical tachometer.

Since the variation of the extracted airflow in the RTV mainly depends on the wind speed and the static pressure conditions, a dimensionless analysis approach has been chosen for these tests, with the Buckingham $\pi$ theorem applied for that purpose. The RTV extracted airflow fundamentally depends on the wind speed, air density, the difference in static pressure between the ventilated room and the outside air, the diameter of the RTV extracted air duct. As a general rule, this process can be expressed as the function $f\left(\dot{Q}_{e}, \rho, u, \Delta P_{s}, d_{i}\right)$. After these variables have been measured against the values of mass, length, and time, the Buckingham $\pi$ theorem is then applied to establish 2 non-dimensional parameters:

$$
\begin{gathered}
\pi_{1}=\frac{\Delta P_{s}}{\rho u^{2}} \\
\pi_{2}=\frac{\dot{Q}_{e}}{u d_{i}^{2}}
\end{gathered}
$$

here $\pi_{1}$ - the first non-dimensional parameter.; $\pi_{2}$ - the second non-dimensional parameter; $\dot{Q}_{e}$ - the RTV extracted airflow, $\mathrm{m}^{3} / \mathrm{s} ; \rho$ - density of air, $\mathrm{kg} / \mathrm{m}^{3} ; u$ - the wind speed, $\mathrm{m} / \mathrm{s} ; \Delta P_{s}-$ the difference in static pressure between the ventilated room and the outside air, $\mathrm{Pa}$.

In terms of construction and function, the RTV resembles the Savonius-type wind power plant, its blades largely affected by drag force. This analogy provides the foundation for the tests of RTV aerodynamic drag characteristics that were carried out for the purposes of this thesis. To estimate the energy generation potential of the subject RTVs, in addition to extracted airflow indicator and aerodynamic characteristic tests, this thesis also involved tests of the amount of power that the devices generate. The tests of the power generated by the RTV are carried out with the rotor mechanically generating load. For that purpose, the upper section of the RTV rotor is connected, via a metal axis, to the torque sensor (Lorenz DR1).

Figure S2.3 shows the results of the dimensionless analysis of all devices tested. 


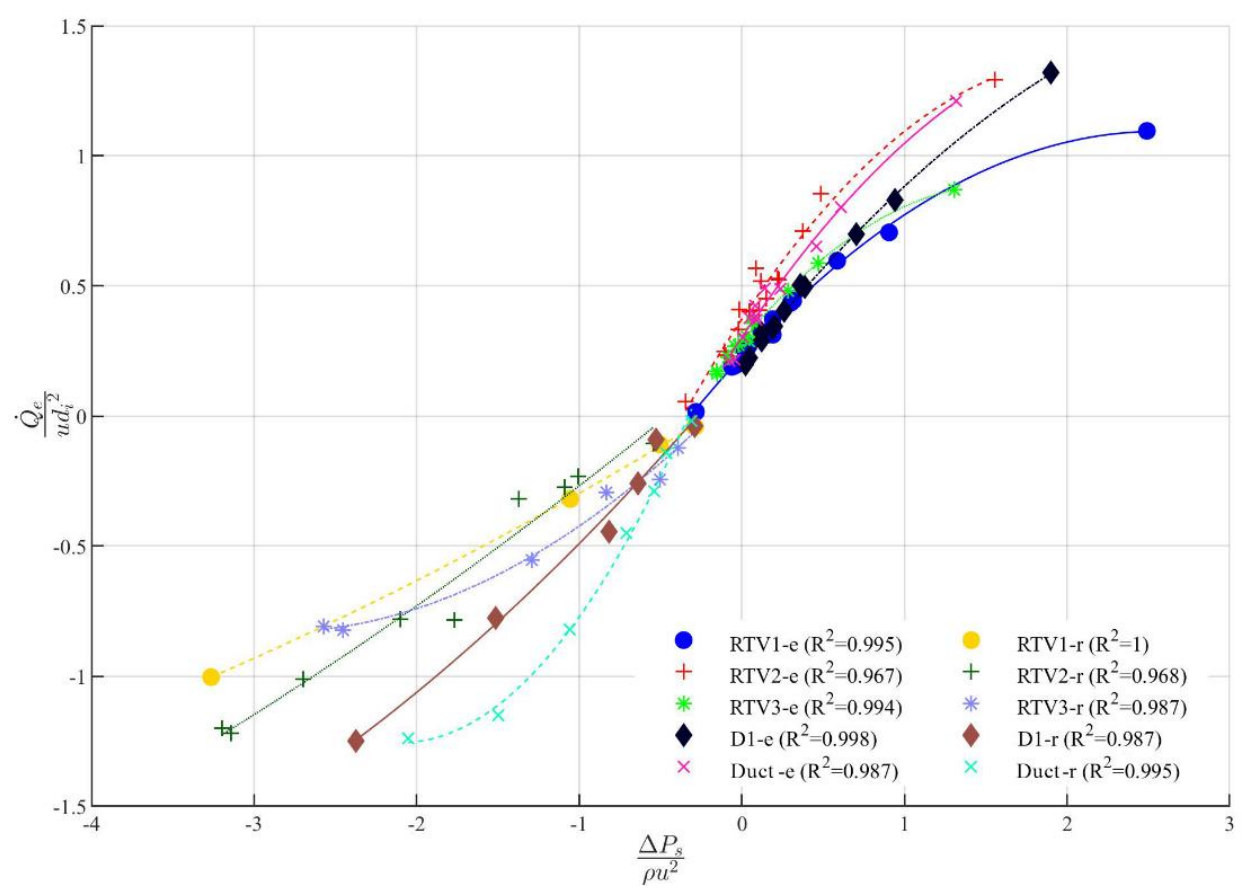

Fig. S2.3. The results of the extracted airflow dimensionless analysis of the tested devices

Explanation of figure S2.3: -e and -r are the direction of the extracted and intake airflow, respectively; $\mathrm{R}^{2}$ is the coefficient of determination of the test result.

Integrated assessment of the variation of differences in wind speed and static pressure shows that, as far as air extracted is concerned, the best performance is achieved by RTV2 (with straight vertical rotor blades). Compared to an open air duct, the extracted airflow of RTV2 can be up to $8 \%$ bigger. Depending on the wind speed and the static pressure conditions, the efficiency of the extracted airflow of the rest of the devices could be lower by up to $30 \%$. In this case, analysis of the RTV1 (rotor blades curved in the direction of the vertical axis) test data shows that the small rotor and the relatively large area of the duct opening cross-section of this device means that this device has the poorest performance ratio among the RTVs tested. Meanwhile, RTV3 (rotor blades curved in the direction of the vertical axis), its construction similar to that of RTV1, shows a slightly higher degree of effectiveness owing to the larger gaps between the blades of its rotor.

Assessment of the test results for the deflector shows that the rain cap installed above the device reduces the air extraction capacity by up to $20 \%$ compared to the open air duct. Tests conducted allowing the extraction of air to take place have showed that all RTV devices tested greatly reduce the amount of wind flow intake compared to the open air duct. In this case, judging by the absolute indicators, the RTV1 device demonstrated an air intake flow rate that was up to 55\% lower. The RTV2 and RTV3 devices reduce the air intake rate by up to $45 \%$. 
The following portion of the experimental RTV research has to do with measuring the RTV torque and calculating the power generated by this device. The tests were carried out at three different wind flow speeds and equal static pressures in the ventilated room and the wind tunnel. The tests create different loads on the RTV's rotation axis and involve taking measurements of the torque values and the RTV rotation frequencies using an optical tachometer for that purpose.

The tests established that the RTV creates straight-line variation of torque depending on rotation frequency. In this case, the highest torque value can be achieved when the rotors of the devices are stationary. Speaking of the torques generated by different devices, the biggest torque is achieved by the RTV3 device. The tests established that, when the rotor is stopped at the maximum wind speed of $9.2 \mathrm{~m} / \mathrm{s}$, the torque stands at about $0.055 \mathrm{Nm}$.

Figure S2.4 shows the results of the calculations of the amount of power generated by the RTV, as established against torque values and the values of torque as per relevant rotor angular frequencies. The figure also presents the curves of extracted airflow variation depending on the rotor load.

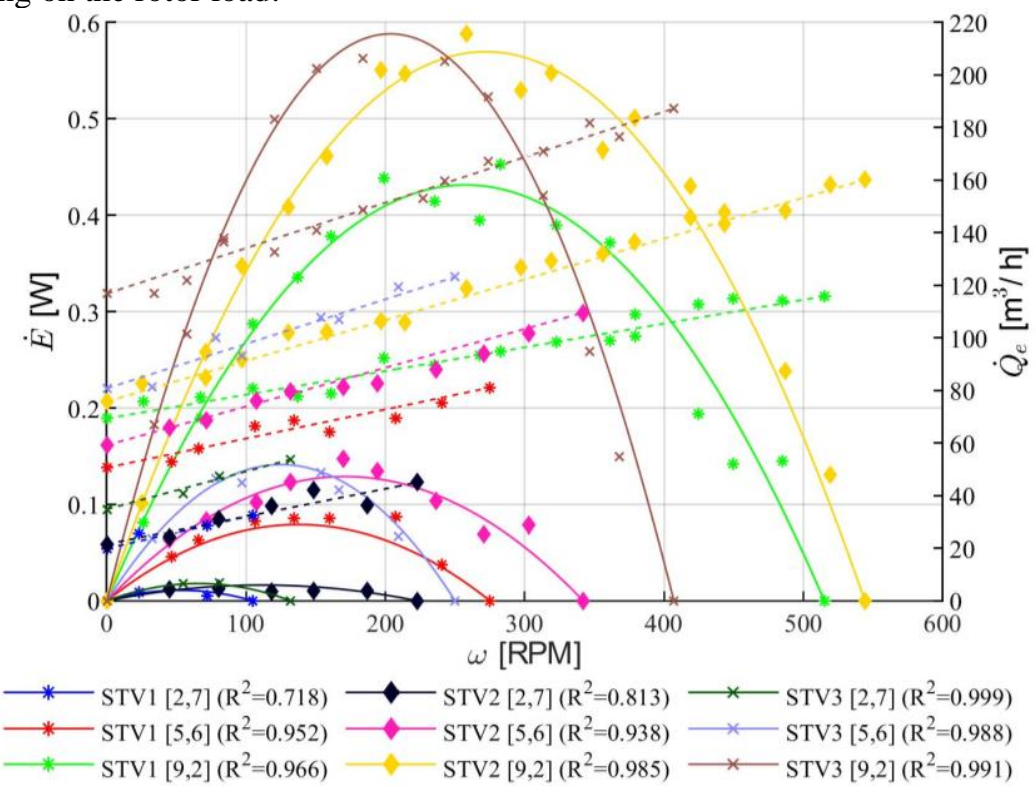

Fig. S2.4. Variation of the power generated by the RTV and extracted airflows at different wind speeds

Legend: the wind speed at $\mathrm{m} / \mathrm{s}$ is given in brackets [ ]; $\mathrm{R}^{2}$ is the coefficient of determination of the test result.

These tests established that, when the wind speed is $9.2 \mathrm{~m} / \mathrm{s}$, the chosen RTV can generate power up to a $0.6 \mathrm{~W}$ maximum. At high wind speeds and higher-than-nominal extracted airflow, this excess energy can be accumulated by the device. In this case, to achieve maximum power for accumulation, the RTVs rotation frequency must be reduced 
by roughly $50 \%$. Nonetheless, with the extracted airflow variation factored in, the extracted airflow in the devices tested can be expected to drop by nearly $20 \%$, therefore, this kind of load on the RTV rotor axis cannot be achieved in some cases, because the amount of extracted air becomes too small to ensure the necessary ventilation of the room.

The results of the calculations of generated power presented in this figure and the one before show that the RTV test results are comparable to the theoretical bounds present in the theory of Savonius-type wind turbines (Twidell \& Weir, 2015). The amount of power generated by the RTV rotor depends on the size of and load on the rotor, and varies as a cubic dependence. Assessment of the effectiveness of the maximum power generated by the RTV and its air extraction rate has revealed that the effectiveness of power generated by such devices is between $4 \%$ and $8 \%$, and the effectiveness of air extraction is between $12 \%$ and $22 \%$. Comparing the effectiveness of wind energy utilisation across the RTVs tested, the best performance is achieved in the RTV2 device.

\section{Thermodynamic model of the triple-component concept of turbine ventilator}

This chapter introduces a thermodynamic model of the roof turbine ventilator based on the hypothesis that the processes taking place inside the device as such combine processes within the wind turbine, the ejector, and the ventilator. Built on this basis, the triple-component concept is grounded on links with the results of the experimental research. The flow processes taking place inside the device are scrutinised by the analogy of the $h-s$ diagrams, which has an application in ejector studies.

The model developed on the basis of this concept allows making a qualitative and quantitative assessment of the impact that the flow processes, which interact while the RTV is in operation, have on the functioning of the device, determining the efficiency and the theoretical potential for improvement using a definite number of experimental characteristics. The thermodynamic model presented here is limited to processes where the flows of wind and extracted air have the same structure and are considered subsonic flow, the flow speeds are subsonic and subject to the inherent qualities of ideal gas. Furthermore, the fluid flow is considered to be one-dimensional and steady-state.

Analysis of the RTV thermodynamic model begins with an assessment of the parameters of the mass flow rates and the state of flow processes at the control volume of the device. The general principles of operation are interpreted and equations needed for the purposes of calculations are derived through abstract schemes that are not connected to a particular device. In this case, considering the specifics of RTV operations and the nature of airflows, the device is approached as an open thermodynamic system.

Figure S3.1 below shows the principal scheme of the RTV complete with the ventilated room. In this scheme, cross-section 0-0 indicates the extracted air inlet; cross-section $1 *-1 *$ corresponds to the boundary of interaction of the wind flow and the RTV's blades; and cross-section 6-6 illustrates the outflow of wind and extracted air out of the RTV. 


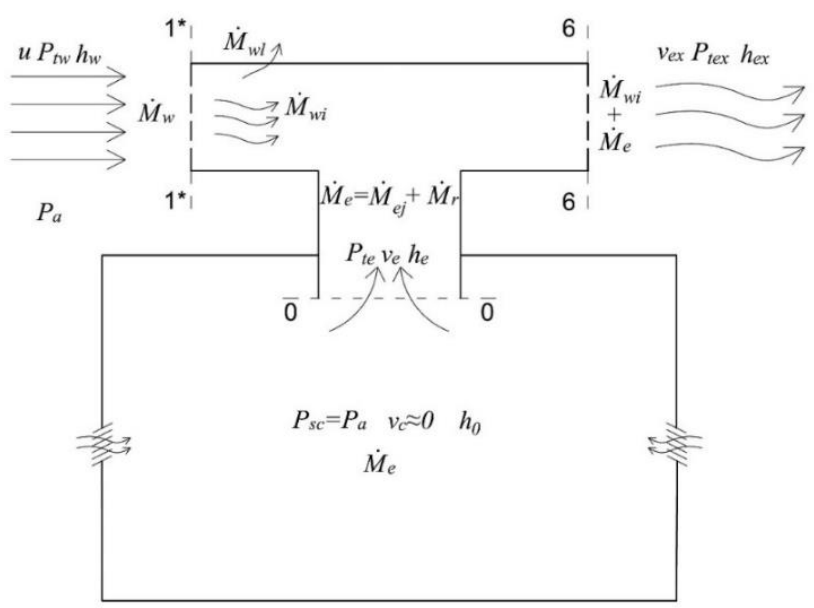

Fig. S3.1. Control volume of turbine ventilator and air flow state parameters

Having considered the airflows entering and exiting the control volume, a summary mass continuity equation is derived:

$$
\dot{M}_{w}^{+}+\dot{M}_{e}^{+}=\dot{M}_{w l}^{-}+\dot{M}_{w i}^{-}+\dot{M}_{e}^{-},
$$

here $\dot{M}_{w}$ - the mass wind flow rate, $\mathrm{kg} / \mathrm{s} ; \dot{M}_{e}$ - the extracted air flow rate, $\mathrm{kg} / \mathrm{s} ; \dot{M}_{w l}-$ the mass rate of the wind flow separated from the rotor's blades, $\mathrm{kg} / \mathrm{s} ; \dot{M}_{w i}-$ the mass rate of the wind flow that has passed the inside of the RTV rotor, $\mathrm{kg} / \mathrm{s}$.

Usually, analysis of flow processes involves an assessment of their internal energy (enthalpy) and the kinetic and potential energy of the flows. When it comes to scrutinising flow processes, the thermodynamic model presented here offers the convenience of applying full enthalpy and complete pressure state parameters that factor in the internal and kinetic energy of the flow. In this case, the wind flow is subject to the following full enthalpy equation:

$$
h_{w}=h_{a}+\frac{u^{2}}{2},
$$

here $h_{w}, h_{a}$ - the full enthalpy of the wind flow and the enthalpy of steady-state atmospheric air, $(\mathrm{J} / \mathrm{kg} \cdot \mathrm{K})$.

Considering that flow processes in this model are considered steady-state and also considering the amount of work done and the losses incurred, the following balance equation is formulated based on the first law of thermodynamics for the open thermodynamic system: 


$$
\dot{M}_{w}^{+} h_{w}+\dot{M}_{e}^{+} h_{0}=\dot{M}_{w l}^{-} h_{1}+\left(\dot{M}_{w i}^{-}+\dot{M}_{e}^{-}\right) h_{e x}+\dot{E}_{R T V}+\dot{Q}_{R T V}
$$

here $h_{0}=h_{a}$ - the full enthalpy of the air inside the room, $(\mathrm{J} / \mathrm{kg} \cdot \mathrm{K}) ; h_{1}$ - the enthalpy of flow entering the RTV's control volume; $h_{e x}$ - the enthalpy of the airflow mixture exiting the device; $\dot{E}_{R T V}$ - is the energy transformation profess during which technical work is carried out, W; $\dot{Q}_{R T V}$ - dissipation, W.

Speaking about the operating principle of the device and considering the outcomes of experimental research, there is a clear similarity in the construction of the RTV and other devices, as well as a structural and interactional connection between them. To be able to understand the fine points of operation of the device, Figure S3.2 shows its topdown cross-sections with the individual hypothetical RTV components decomposed. The airflow processes that interact inside the device are portrayed by breaking the RTV down into hypothetical components of the turbine, the ejector, and the ventilator.

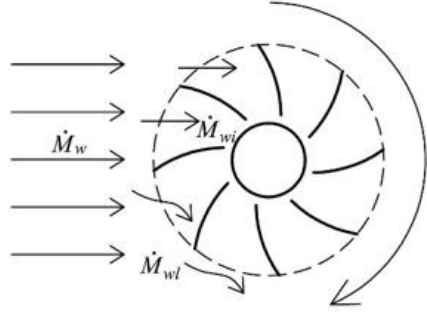

a)

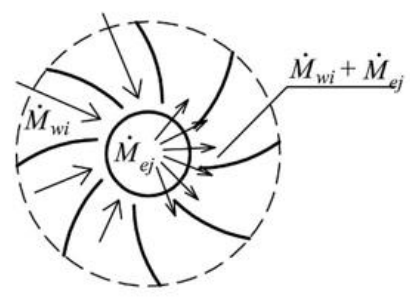

b)

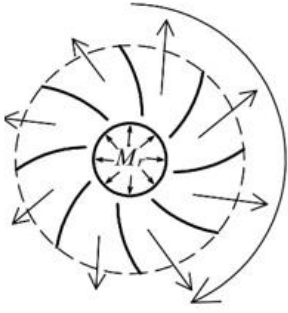

c)

Fig. S3.2. The turbine ventilator structural breakdown into hypothetical components: a) turbine; b) ejector; c) ventilator

Follows the integral thermodynamic model of this triple-component RTV concept. In this case, the thermodynamic models of individual components are used as a basis on which a common RTV model is built, complete with analytical examples of its application. In this case, the following system of equations is designed to resolve the model:

$$
\left\{\begin{array}{l}
\dot{M}_{w} \cdot\left(h_{1^{*}}-h_{0}\right) \cdot \eta_{t} \cdot \varepsilon_{t}=\dot{M}_{r} \cdot\left(h_{5}-h_{0}\right) \\
\dot{M}_{w} \cdot k_{w l} \cdot\left(h_{1^{*}}-h_{0}\right) \cdot\left(1-\eta_{r} \cdot \eta_{t}\right) \cdot \eta_{e j} \cdot \varepsilon_{e j}=\dot{M}_{e j} \cdot\left(h_{3}-h_{0}\right) \\
\dot{M}_{r} \cdot\left(h_{5}-h_{0}\right)+\dot{M}_{e j} \cdot\left(h_{3}-h_{0}\right)=\dot{M}_{w} \cdot\left(h_{1^{*}}-h_{0}\right) \cdot \varepsilon_{Q} \\
\dot{M}_{r} \cdot\left(h_{5}-h_{0}\right)=k_{p r} \cdot \dot{M}_{e j} \cdot\left(h_{3}-h_{0}\right)
\end{array}\right.
$$

here $\eta_{t}, \eta_{e j}$ - isentropic ratios of the turbine and the ejector; $\varepsilon_{t}, \varepsilon_{e j}-$ the portion of the wind flow energy for the turbine and the ejector; $\varepsilon_{Q}-$ the air extracted efficiency, $k_{e j}-$ the ratio of the ejected airflow.

With this system of energy balance equations applied and making assumptions regarding the isentropic utility ratios of the device, one can draw an $h$-s diagram depicting the variation of the airflow processes taking place in the RTV. In this case, the RTV2 
device is chosen as the numeric example of the model presented here. The numeric example is not limited to just the maximum wind speed achieved during the experiments $(9.2$ $\mathrm{m} / \mathrm{s}$ ), and isentropic ratios are determined on the basis of data available in scientific literature (Fang Liu \& Groll, 2013). The model assumes that the isentropic ratio values of the turbine and the ejector are 0.8 , and the ratio of the separated wind flow is 0.7 .

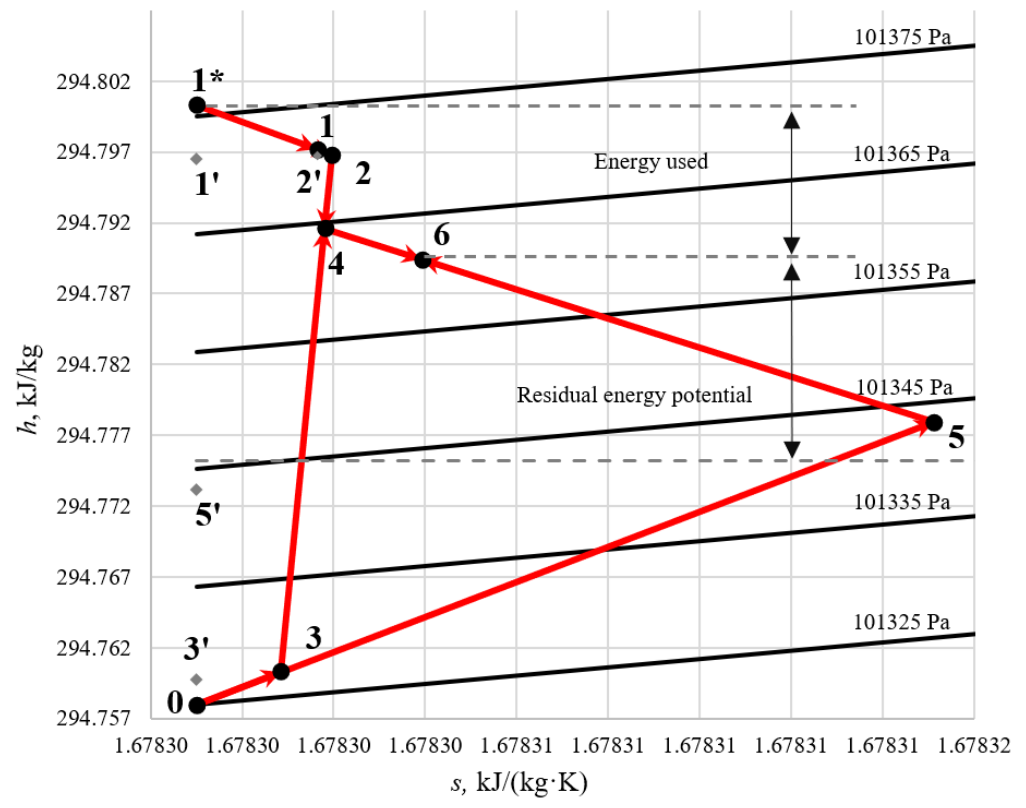

Fig. S3.3. Integral h-s diagram of STV2 thermodynamic processes

Analysis of the above scheme shows the following processes to be taking place while the RTV is in operation: during process $1 *-1$, the wind flow affects the turbine and performs work identical to that performed by the RTV's ventilator. In this case, part of the wind flow separates from the rotor following interaction. During process 1-2, the wind flow that enters the RTV rotor continues to be involved in the process of ejection. In this case, the wind flow has a suction effect on some of the air in the room and is assigned to the active flow. During the ejection, the wind flow energy is used to extracted air from the room. Process 0-3 shows the extraction of the air in the room due to ejection taking place. Processes 2-4 and 3-4 illustrate the mixing of the wind flow and the airflow subjected to suction during the ejection. Process $0-5$ indicates the air extraction from the room by the RTV ventilator. Processes 4-6 and 5-6 feature the final process where the air suctioned by the ventilator mixes with the wind flow and the mixture of the wind flow and the air suctioned via the ejection.

The numeric case of the model presented here shows how, as the wind flow blows into the RTV, part of the flow energy is consumed to spin the rotor, and another part is used up in the process of ejection. Besides, analysis of the results indicates that the airflow passing through the device needs to have enough energy to flow out of the RTV. In this 
case, measuring the maximum consumption of the wind flow energy relies on the theoretical limit of the Betz criterion that applies in wind power plants. The thermodynamic model assumes that, at the highest efficiency of the device, the energy of the wind flow could theoretically decrease by $59.3 \%$ max (the horizontal dashed straight line in Figure 3.3).

The results of the numeric case have allowed reaching a determination that the energy of the airflow leaving the device drops by $25.7 \%$ (labelled 'Energy used' in the diagram) compared to the original wind flow energy. Whereas, considering the limit of the Betz criterion, the potential of unused energy is $33.6 \%$ (labelled 'Residual energy potential' in the diagram).

Analysis of the overall efficiency of wind flow energy utilisation has showed the best performance in device RTV2, and the worst, in device RTV1. In this case, RTV2 is in line with the result of the above numeric case, which is $25.7 \%$, whilst RTV1 and RTV3 are at $18.1 \%$ and $21.2 \%$, as appropriate. These results show that the utilisation of wind energy in all RTVs is more than twice below the possible theoretical limit of the Betz criterion.

This chapter further features a theoretical assessment of boosting the functionality of turbine ventilators in reliance of the experimental research results. Calculations of the annual volume of air extracted by the RTV are based on a hypothetical warehouse located in the city of Vilnius, and wind speed variation is based on one-minute interval data from the Meteonorm application. In this case, the RTV is approached on the basis of the average annual wind speed of $3.9 \mathrm{~m} / \mathrm{s}$ in that particular location and the average RTV2 extracted airflow of $74 \mathrm{~m}^{3} / \mathrm{h}$. Considering these criteria, the RTV is designed for a room with a floor space area of $68.5 \mathrm{~m}^{2}$. Figure $\mathrm{S} 3.3$ shows the results of the calculations when the RTV2 rotor is used to accumulate energy.

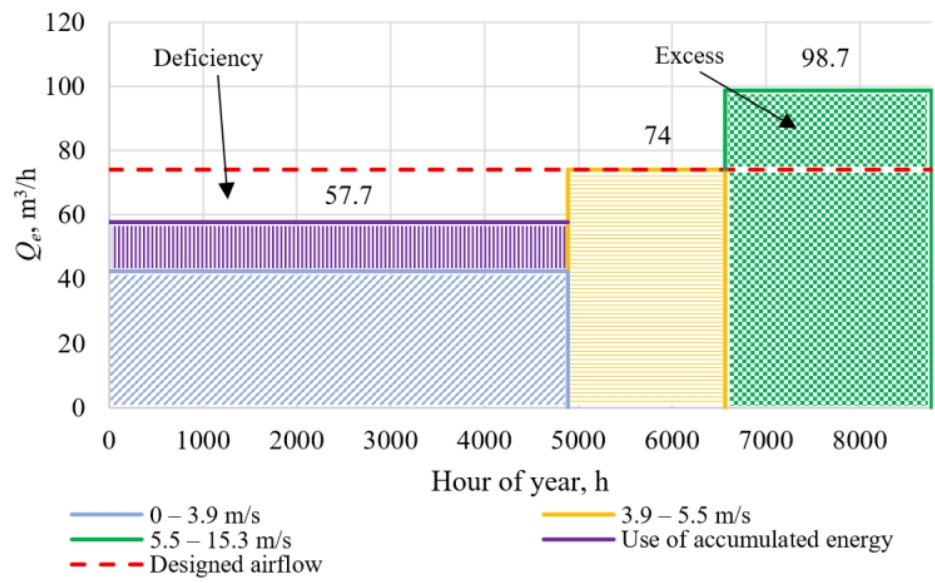

Fig. S3.3. The average distribution of the extracted airflow with accumulated energy

The results of the calculations show that with the wind speed within the range of 3.9 and $5.5 \mathrm{~m} / \mathrm{s}$, the device can operate under partial load and produce a designed extracted airflow of $74 \mathrm{~m} 3 / \mathrm{h}$. With the wind speed above the designed value, electricity is generated 
at the maximum RTV rotor load. With RTV2 operating under these conditions, the average extracted airflow would be around $98.7 \mathrm{~m} 3 / \mathrm{h}$. Compared with the designed airflow, it would appear that this results in an excess of about $33 \%(24.7 \mathrm{~m} 3 / \mathrm{h})$. During the remaining $57 \%$ of the time, the RTV operates in combined mode. With the wind speed below $3.9 \mathrm{~m} / \mathrm{s}$, the extracted airflow would be increased using the accumulated electrical energy that spins the RTV rotor. The calculations have determined that under such conditions of operation, the average extracted airflow of the RTV during this period could increase by roughly $36 \%(15.4 \mathrm{~m} 3 / \mathrm{h})$. Whereas the annual functionality of ventilation can be boosted by nearly $11.6 \%$. Under the scenario chosen, this hybrid ventilation system would satisfy about $87.7 \%$ of the annual demand.

\section{General conclusion}

1. It has been experimentally determined that the extracted airflow of the RTV depends significantly on the wind speed, the difference in the static pressure between the ventilated room and the outside, and the aerodynamic properties of the RTV. Considering all aspects of variation of wind speeds and the static pressure in the room, the best air extracted performance is achieved by RTVs with straight vertical blades (RTV2). Allowing for wind flow intake to occur during the tests, it has been observed that the test devices reduce the amount of intake wind flow by between $25 \%$ and $55 \%$ compared to an open air duct. Assessment of the efficiency ratios of the maximum power generated by the RTV and the air extraction has revealed that the efficiency of the power generated by these devices is between $4 \%$ and $8 \%$, with the air extraction efficiency of $12 \%$ to $22 \%$.

2. The results of the experimental research and the principle of RTV operation have led to a determination that the RTV shares a structural and interactional connection with other aerodynamic devices. The processes of airflows interacting in the RTV can be analysed and the efficiency of the device tested through application of a triple-component concept of operation of the device, which is expressed as a thermodynamic model. This triple-component RTV consists of hypothetical components: a turbine, an ejector, and a ventilator.

3. The thermodynamic model that integrates the hypothetical components of the turbine, the ejector, and the ventilator that has been developed allows assessing, within the scope of this research, the impact of the flow processes that interact in the RTV on the functionality and efficiency of the device as well as its potential for improvement. After the model was linked to experimental research and the necessary presumptions were made, the find flow was found to consume between $2.9 \%$ and $9.1 \%$ of its theoretical power to spin the rotor in the case of the RTVs under analysis. The application of the thermodynamic model revealed that the theoretical maximum extracted airflow can be at least twice as voluminous.

4. The RTV thermodynamic model developed on the grounds of various multifaceted experimental RTV research and statistical data on annual wind speed variation has allowed measuring the extracted airflow of the RTV and the potential for accumulation on a hybrid ventilation system, as well as revealing the possibility to increase the functionality of hybrid ventilation systems that use variable wind energy. Based on the RTV2 hybrid ventilation system installed in Vilnius as chosen for the purposes of analysis, this solution has been found to possibly improve the annual ventilation functionality by nearly $11.6 \%$ in theory. 
Priedai $^{3}$

\begin{abstract}
A priedas. Sąžiningumo deklaracija
B priedas. Bendraautoriu sutikimai teikti publikacijose skelbtą medžiagą daktaro disertacijoje

C priedas. Autoriaus mokslinių publikacijų disertacijos tema kopijos
\end{abstract}

${ }^{3}$ Priedai pateikiami pridètoje kompaktinejje plokštelèje. 


\section{Dovydas RIMDŽIUS}

\section{VĖJO ENERGIJA NAUDOJANČIO TURBININIO \\ VENTILIATORIAUS TERMODINAMINIS MODELIS}

Daktaro disertacija

Technologijos mokslai, mechanikos inžinerija (T 009)

THERMODYNAMIC MODEL OF WIND DRIVEN TURBINE VENTILATOR

Doctoral Dissertation

Technological Sciences,

Mechanical Engineering (T 009)

202103 26. 12,5 sp. I. Tiražas 20 egz.

Leidinio el. versija https://doi.org/10.20334/2021-007-M

Vilniaus Gedimino technikos universitetas

Saulètekio al. 11, 10223 Vilnius

Spausdino Bl UAB „Baltijos kopija“,

Kareivių g. 13B, 09109 Vilnius 